KARINE PETRY DE AGUIAR

\title{
Ambientes comerciais e a influência do design visual
}

\author{
Dissertação apresentada à Faculdade de \\ Arquitetura e Urbanismo da Universidade \\ de São Paulo como parte dos requisitos \\ necessários à obtenção do título de Mestre \\ em Arquitetura e Urbanismo \\ Área de Concentração Design e Arquitetura \\ Linha de Pesquisa Design e Arquitetura: Interrelações
}

Orientador: Prof. Dr. Carlos Roberto Zibel Costa

São Paulo, 2016. 
AUTORIZO A REPRODUÇÃO E DIVULGAÇÃO TOTAL OU PARCIAL DESTE TRABALHO, POR QUALQUER MEIO CONVENCIONAL OU ELETRÔNICO, PARA FINS DE ESTUDO E PESQUISA, DESDE QUE CITADA A FONTE.

E-mail da autora: karine_petry@hotmail.com

Aguiar, Karine Petry de

A282a Ambientes comerciais e a influência do design visual / Karine

Petry de Aguiar. -- São Paulo, 2016.

231 p. : il.

Dissertação (Mestrado - Área de Concentração: Design e Arquitetura) - FAUUSP.

Orientador: Carlos Roberto Zibel Costa

1.Comércio 2.Arquitetura 3.Design 4.Fachadas comerciais

5.Merchandising visual I.Título

CDU 339

"As opiniões, hipóteses e conclusões ou recomendações expressas neste material são de responsabilidade da autora e não necessariamente refletem a visão da FAPESP". 


\title{
Ambientes comerciais e a influência do design visual
}

\author{
Dissertação apresentada à Faculdade de Arquitetura e \\ Urbanismo da Universidade de São Paulo para obtenção do \\ título de Mestre em Arquitetura e Urbanismo
}

Aprovado em:

\section{Banca Examinadora}

Prof. Dr.

Instituição:

Julgamento:

Assinatura:

Prof. Dr. Instituição:

Julgamento:

Assinatura:

Prof. Dr. Instituição: 
Dedico esse trabalho aos meus pais Marcos e Laura, minha irmã Andrea e ao meu companheiro de todas as horas, Diego. 


\section{AGRADECIMENTOS}

Agradeço imensamente aos meus pais e minha irmã, por todo amor e confiança que sempre depositaram em mim e, principalmente, pelo imenso apoio, cuidado e incentivo incansável.

A toda minha gigantesca família, minhas tias e tios, e em especial minha prima-irmã do coração, Rose, por sempre se fazer presente, pelas mensagens e palavras de carinho e pela energia positiva que sempre me transmite.

Ao meu orientador, professor Carlos Zibel, pelo estímulo para a realização deste trabalho e aprendizados que foram além dessa dissertação.

À Fundação de Amparo à Pesquisa Científica do Estado de São Paulo - FAPESP, pela concessão da bolsa de mestrado (processo no 2014/02429-7) e apoio financeiro para a realização desta pesquisa.

Aos professores que participaram da Comissão Examinadora, por toda contribuição ao desenvolvimento desta pesquisa.

A todos os professores e funcionários da FAUUSP pelos ensinamentos e ajuda prestados, especialmente a professora Cibele Haddad, pela sua preocupação, atenção e por todos os momentos que se mostrou extremamente afetuosa e prestativa ao me atender.

Aos meus amigos, em especial a Mariana Todorov, que me recebeu de braços abertos na terra da garoa.

Ao Diego NormandINHO, por tudo. Pela paciência, conselhos e melhores momentos na FAU. 
"A cidade de Leónia refaz-se a si própria cada dia que passa: todas as manhãs a população acorda no meio de lençóis frescos, lava-se com sabonetes acabados de tirar da embalagem, veste roupas novinhas em folha, extrai do mais aperfeiçoado frigorífico frascos e latas ainda intactos, ouvindo as últimas canções no último modelo do aparelho de rádio."

As cidades invisíveis. Ítalo Calvino (1990) 


\section{RESUMO}

AGUIAR, Karine Petry de. Ambientes comerciais e a influência do design visual. 2016. 231f. Dissertação (Mestrado) - Faculdade de Arquitetura e Urbanismo, Universidade de São Paulo, São Paulo, 2016.

O comércio foi uma das razões que impulsionaram os amplos investimentos em infraestrutura e desenvolvimento dos meios de transporte, com o intuito de facilitar o deslocamento por grandes distâncias. Além de influenciar diretamente o surgimento dos contratos mercantis, das instituições financeiras e da moeda. O comércio, na forma como conhecemos hoje, teve início com o escambo, que ocorria em feiras itinerantes. Com o tempo, houve a necessidade de se estabelecer um local fixo onde fossem promovidas tais trocas. Com isso, surgiram os primeiros armazéns de secos e molhados, que propiciaram a base para a arquitetura comercial. A pouca relevância dada a este tipo de arquitetura, bem como a influência clara do comércio na paisagem urbana, foram os impulsos necessários para este projeto. Os ambientes comerciais são a estética dos espaços urbanos e, muitas vezes, são projetados sem a devida preocupação em conciliar a arquitetura com ferramentas de design visual, como o merchandising visual, que permitem projetar ambientes que se comuniquem melhor com os consumidores e com a cidade. $O$ presente mestrado consiste em uma pesquisa para levantar, identificar e indicar parâmetros pertinentes ao design visual aplicados em fachadas de estabelecimentos comerciais e as influências do modo de consumir do sujeito pós-moderno na concepção destes espaços.

Palavras-chave: comércio, arquitetura, design, fachadas comerciais, merchandising visual. 


\section{ABSTRACT}

AGUIAR, Karine Petry de. Commercial Architecture and the influence of visual design. 2016. 231f. Dissertação (Mestrado) - Faculdade de Arquitetura e Urbanismo, Universidade de São Paulo, São Paulo, 2016.

Commerce was one of the main reasons that boosted investments in infrastructure and development of transportation systems with the intent to facilitate long-distance movement. It also influenced directly the emergence of commercial contracts, financial institutions, and currencies. Commerce, as we know it, began with the exchange of goods and services that happened in roving markets. With time, as the demand grew, there was a rise in the need for an established location where trade could expand. That enabled the development of the first warehouses of dried and liquid goods which formed the base for commercial architecture. The low level of importance given to this type of architecture along with the influence of commerce in the urban landscape were the key motivations for this project. The places of trade area the aesthetically shape urban spaces and, in many cases, these places do not align the architecture with tools of Visual Design, such as visual merchandising, which allow us to design environments that better communicate with the consumers and the city. This present study aims to find out, identify and specify parameters relevant to the visual design applied in commercial storefronts and influences the way of consuming the postmodern subject in the design of these spaces.

Keywords: trade, architecture, design, commercial storefronts, visual merchandising. 


\section{LISTA DE FIGURAS}

Figura 1. Shopping Iguatemi de Florianópolis, mais um caixote comercial ......................................21

Figura 2. Estampa desenvolvida pelo estilista Alexandre Herchcovitch ...........................................22

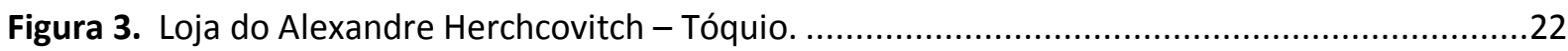

Figura 4. Prédio do antigo Bingo da Imperatriz, que se manteve como referencial da avenida 23 de maio em São Paulo, mesmo depois do seu fechamento em 2007.....................................................36

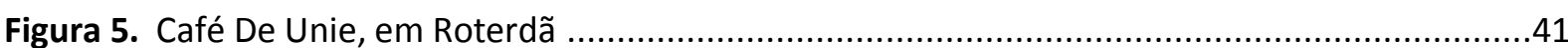

Figura 6. Loja Pop Club em Fortaleza traz na sua fachada 3 categorias de mídia: Existe a mídia de

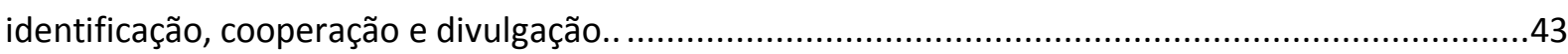

Figura 7. A comunicação visual urbana em Times Square - Nova lorque ........................................44

Figura 8. Relógio do Conjunto Nacional ainda com o logotipo do Itaú fixado em 2007......................46

Figura 9. Relógio do Conjunto Nacional sem o logotipo do Itaú em 2013 ........................................46

Figura 10. Organograma representando o modelo de processo decisório …................................52

Figura 11. Imagens do avô e do carro (que teria sido usado para vender sorvete na Itália) que

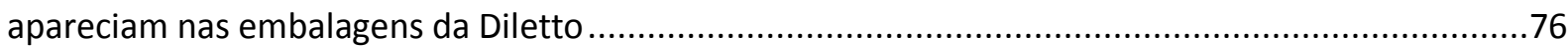

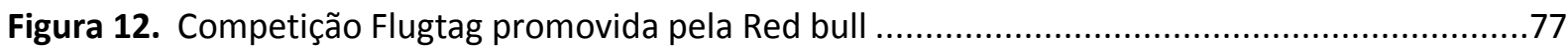

Figura 13. Fachada da loja American Girl Place em Nova Iorque........................................................79

Figura 14. Bonecas vendidas na American Girl Place que permitem a individualização por parte do

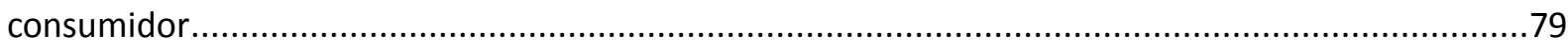

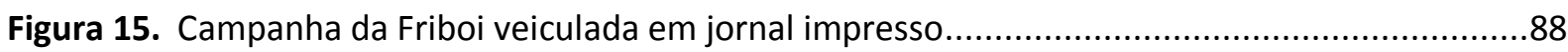

Figura 16. Mercado São Jorge - Loja especializada em produtos orgânicos de Florianópolis/SC........90

Figura 17. Três tipos de selos encontrados nas embalagens: Leaping Bunny, Peta e Not Tested On Animals Australia

Figura 18. Anúncio publicitário da Unimed Blumenau/SC veiculado em 2005 100 


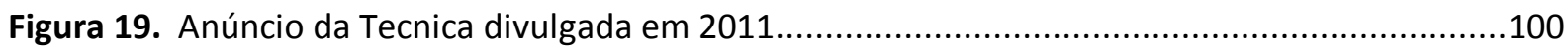

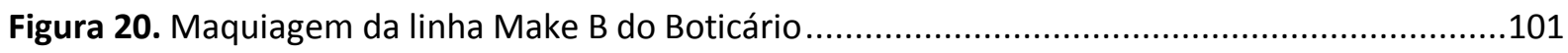

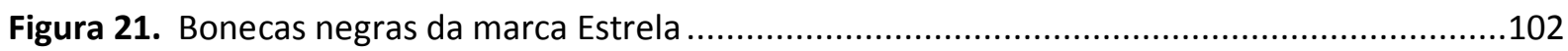

Figura 22. Flores de chocolate da vitrine de uma confeitaria em Las Vegas ...................................113

Figura 23. Vitrine sem fundo da loja de acessórios ULM em Florianópolis. .....................................116

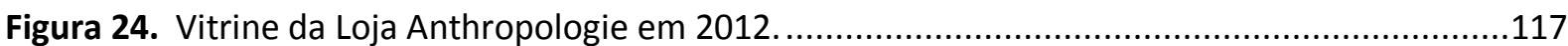

Figura 25. Vitrine da loja Chanel em Paris, onde o teto foi utilizado para fixar balanços que apoiam

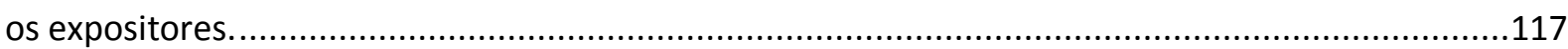

Figura 26. Loja de departamento Steffl em Viena na sua inauguração...........................................119

Figura 27. Vitrine da loja Schutz do Shopping Morumbi - São Paulo. ............................................119

Figura 28. Prédio comercial localizado no centro histórico de Florianópolis...................................120

Figura 29. Vitrine aberta de uma loja do shopping Iguatemi.....................................................121

Figura 30. Vitrine aberta de uma loja de rua de Florianópolis.......................................................122

Figura 31. Vitrine fechada de uma loja do Shopping Iguatemi. .................................................123

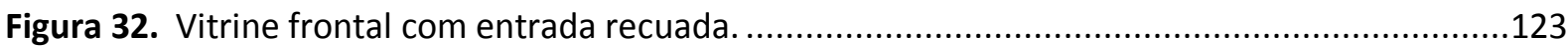

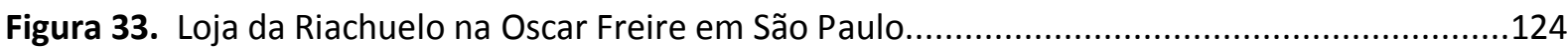

Figura 34. Loja de calçados com vitrine corredor localizada no centro de Florianópolis ...................124

Figura 35. Livraria da Vila aberta e fechada - São Paulo/SP .......................................................125

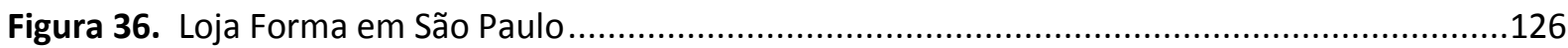

Figura 37. Vitrine suspensa da loja de joias H.Stern do shopping Iguatemi Florianópolis. ...............126

Figura 38. Nichos como forma de vitrine para expor tênis ...........................................................128

Figura 39. Vitrine tipo balcão na loja Vivara do Shopping Iguatemi ................................................128

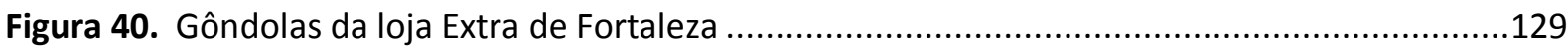

Figura 41. Vitrine popular, onde é possível ver o excesso de produtos expostos.............................131

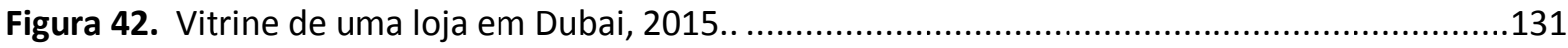

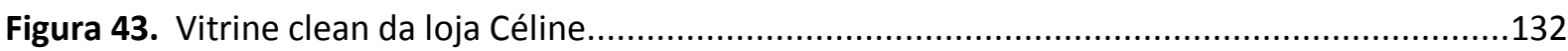

Figura 44. Vitrine cenário da loja Dolce \& Gabbana (Milão) onde é retratado uma cena de um salão

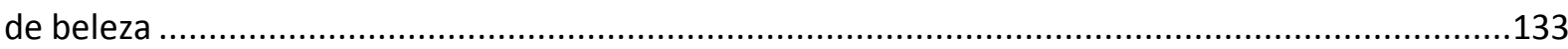

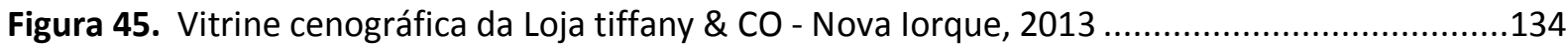

Figura 46. Vitrine conceitual da Chanel em Paris (2011) .........................................................134

Figura 47. Vitrine da loja Hermès com a instalação do designer Tokujin Yoshioka .........................135

Figura 48. Sequência dos movimentos do vídeo da instalação de Tokujin Yoshioka .........................135

Figura 49. Vitrine publicitária para o lançamento do perfume Miss Dior em 2012 .........................137

Figura 50. Vitrine da loja Richards do Shopping Iguatemi Florianópolis. ......................................138 
Figura 51. Vitrine comemorativa do dia dos pais na Renner, 2011............................................139

Figura 52. Vitrine da loja Pucker Up para o dia dos namorados ..................................................139

Figura 53. Vitrine comemorativa do inverno da loja Anthropologie, 2009. .................................140

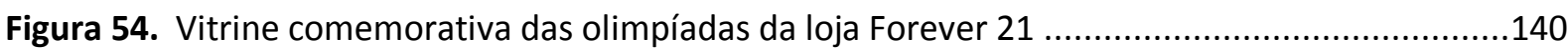

Figura 55. Vitrine da Chanel na loja Printemps - Paris................................................................141

Figura 56. Vitrine da loja Bergdorf Goodman em Nova lorque (2013) sob o título "Punk Influence: Past, Present, Future" [Influência punk: passado, presente, futuro] ..............................................142

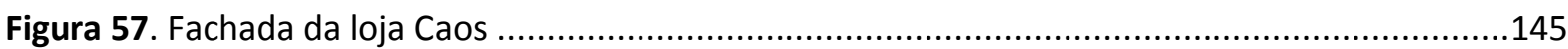

Figura 58. Sinalização da marca da loja na fachada é feita por letras caixa. ...................................146

Figura 59. Fachada da loja Caos vista a noite, detalhe para os luminosos de neon........................146

Figura 60. Vitrine da loja Caos Fonte: Acervo pessoal da autora. ...............................................147

Figura 61. Parte interna da loja Caos. Fonte: Acervo pessoal da autora. ......................................148

Figura 62. Rádios expostos em prateleiras dentro da loja Caos....................................................148

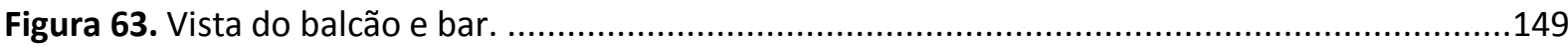

Figura 64. Galeria Melissa enquanto aberta, em abril de 2014 (São Paulo - SP) .............................150

Figura 65. Galeria Melissa durante o horário de fechamento, em junho de 2014 (São Paulo - SP)..152

Figura 66 Loja Havaianas aberta e fechada (São Paulo) ..............................................................153

Figura 67. Loja da Louis Vuitton na Champs-Elysees em Paris.........................................................154

Figura 68. Mala gigante da Goyard, indicando a localização da futura loja na Mount Street Inglaterra.

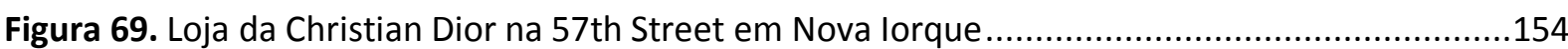

Figura 70. Entrada do contêiner da Experiência Zero Grau da loja Decathlon .................................156

Figura 71. Espaço interno do contêiner onde ocorria a experiência Zero Grau...............................156

Figura 72. Loja Build-a-bear worshop do shopping Eldorado (São Paulo) .......................................157

Figura 73. O processo da experiência na Loja Build-a-bear worshop............................................157

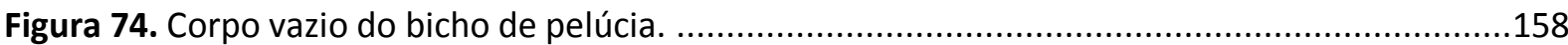

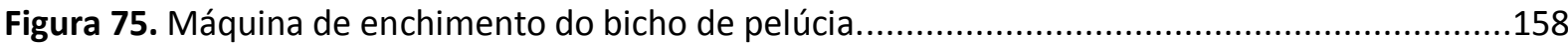

Figura 76. Coração sendo colocado no interior do bicho de pelúcia .............................................158

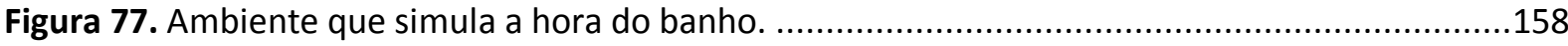

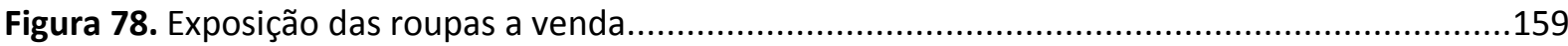

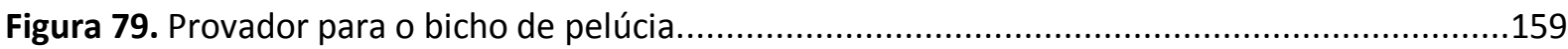

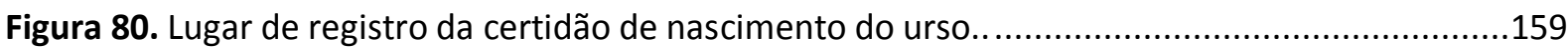

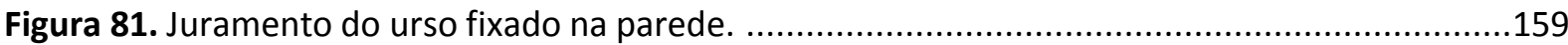

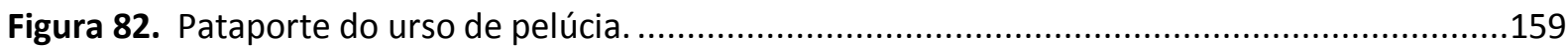


Figura 83. Caixa-sacola do urso de pelúcia da Build-a-bear.

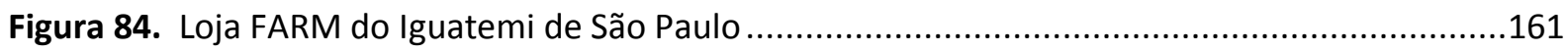

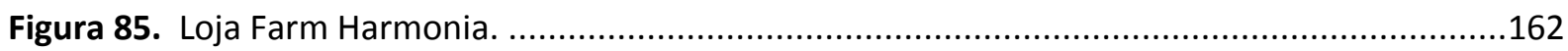

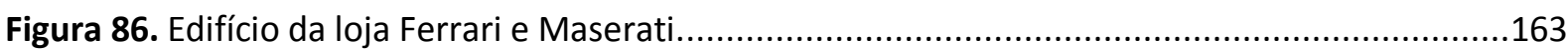

Figura 87. Maquete eletrônica com vista superior da edificação da loja Ferrari e Maserati.............164

Figura 88. Vitrine com composição simétrica a partir de um eixo central vertical da loja Selfridges de

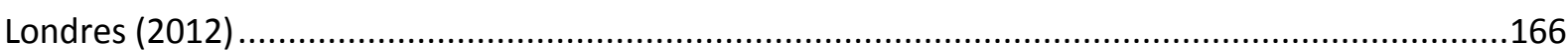

Figura 89. Esquema demonstrando a simetria rígida, variável e polar, respectivamente.................166

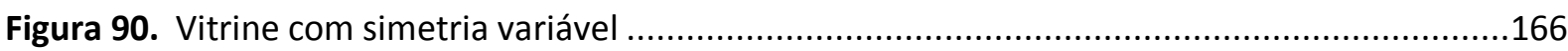

Figura 91. Vitrine da loja Louis Vuitton com composição simétrica polar. ....................................167

Figura 92. Vitrine assimétrica da loja Mara Mac em Belo Horizonte (2012) .................................167

Figura 93. Ritmo da vitrine da loja Louis Vuitton, proveniente da disposição para cima e para baixo

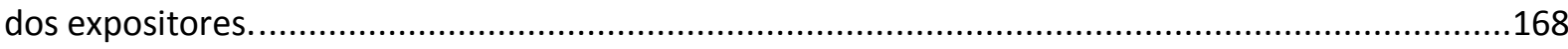

Figura 94. Vitrine da Louis Vuitton trabalha com a repetição de gaiolas ........................................169

Figura 95. Vitrine da loja Chloé expõe uma sequencia repetida de manequins suspensos. .............169

Figura 96. Vitrine com linhas verticais da loja Harvey Nichols ...................................................170

Figura 97. Vitrine com linha horizontal da loja Bergdorf Goodman .............................................170

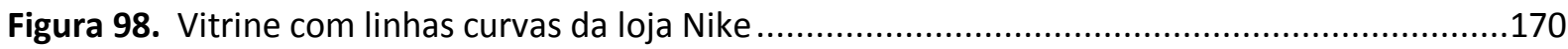

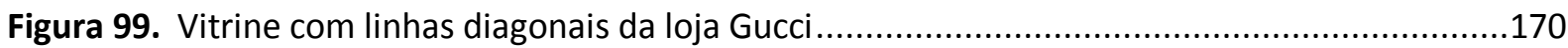

Figura 100. O fundo da vitrine é composto por formas retangulares - Loja Peek \& Clopemburg em Dusseldorf

Figura 101. Os elementos da vitrine da loja da Louis Vuitton formam um triângulo.......................171

Figura 102. Nesta vitrine da Dior é explorado o recurso da escala reduzida ..................................172

Figura 103. Nesta loja da Chanel, tanto o produto comercializado quando o elemento decorativo estão numa escala maior

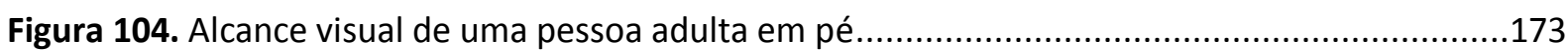

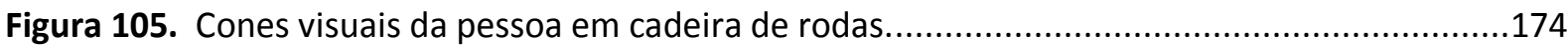

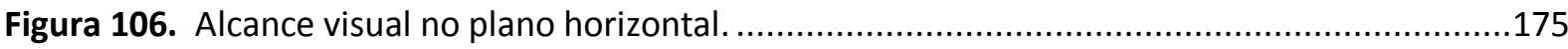

Figura 107. Nível de percepção do usuário ao longo da vitrine .....................................................175

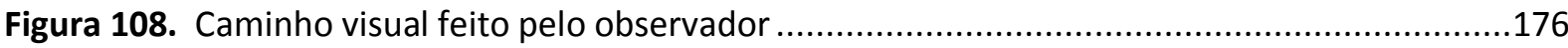

Figura 109. Variação da tonalidade da luz conforme de temperatura de cor ...............................177

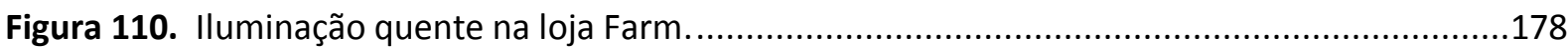

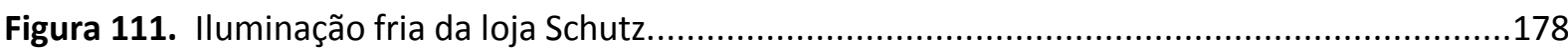

Figura 112. Lâmpadas com diferentes IRC: Baixo IRC (foto esquerda) X Alto IRC (foto direita) ........179 
Figura 113. Círculo Cromático

Figura 114. Vitrines monocromáticas da loja Printemps (2011) .................................................182

Figura 115. Vitrine com harmonia análoga da loja H\&M com fundo em cores análogas..................183

Figura 116. Vitrine com harmonia complementar da loja United Colors of Benetton (2012) ...........183

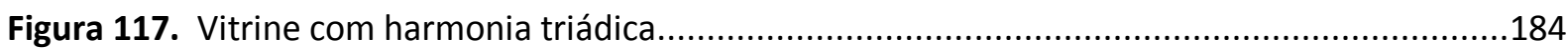

Figura 118. Vitrine com harmonia acromática da loja Printemps (2010) ......................................184

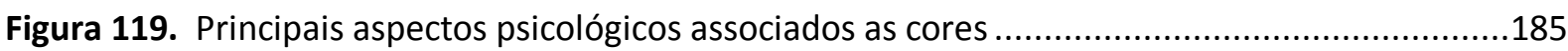

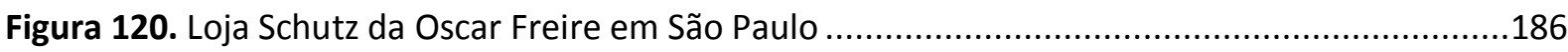

Figura 121. Vitrine da Tiffany \& Co. em New York (2009) ..........................................................186

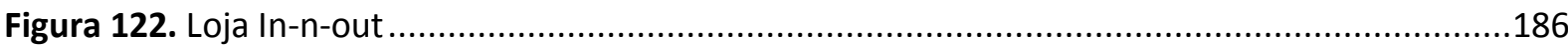

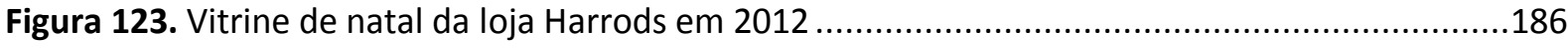

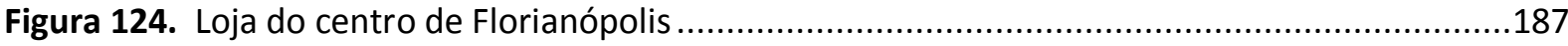

Figura 125. Vitrine da loja Cole Fox Hardware em São Francisco ................................................187

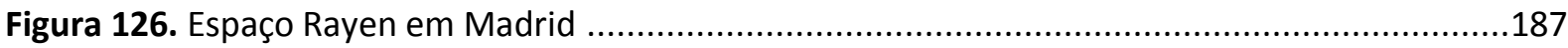

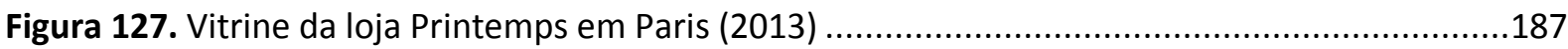

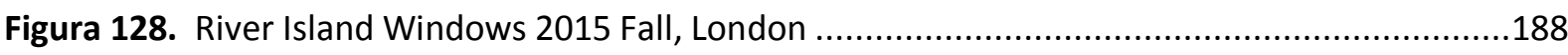

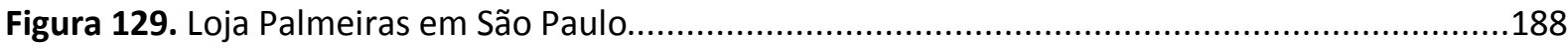

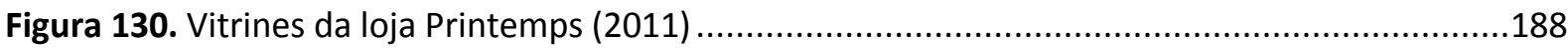

Figura 131. Fachada da loja Maison Bleue em Edimburgo - Escócia .............................................189

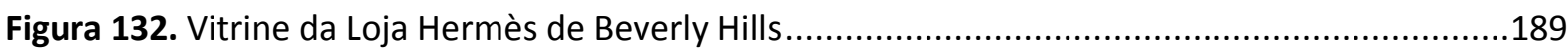

Figura 133. Loja Santa Elena (2010) da rua Oscar Freire - São Paulo ................................................190

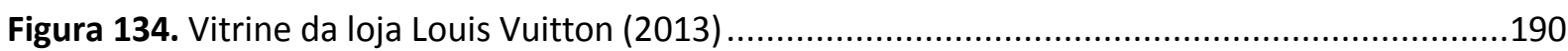

Figura 135. Loja do Herchcovitch em São Paulo, onde o preto é fortemente explorado. .................190

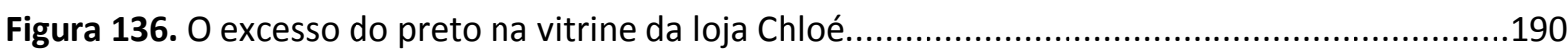

Figura 137. O preto na composição das vitrines de marcas de luxo ...............................................191

Figura 138. Suporte de metal da vitrine da Dior em Paris (2014) ..................................................192

Figura 139. Suporte formando por diversos sacos empilhados na vitrine da loja Max Mara em Milão

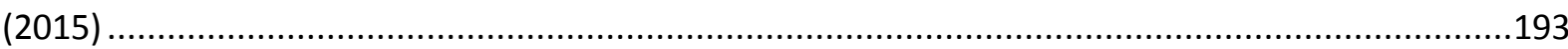

Figura 140. Grandes mãos funcionam como suporte da loja Fenwick em Londres (2015) ................193

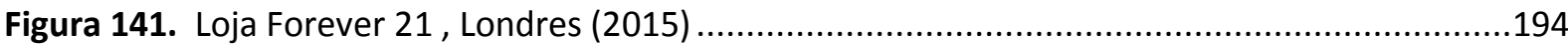

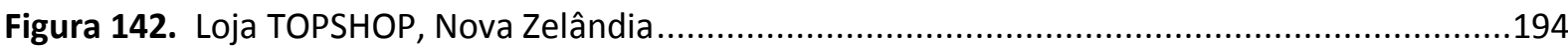

Figura 143. Cubos de metal da loja GLASSONS da Nova Zelândia.................................................195

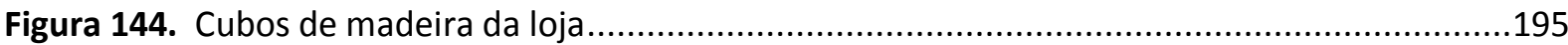

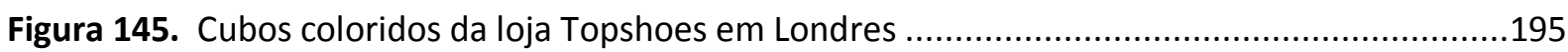


Figura 146. Cubos coloridos no formato de caixas de presente em Nova lorque 196

Figura 147. Vitrine da loja Maria Filó em São Paulo (2011) ........................................................196

Figura 148. Nichos na vitrine Clarks em Londres (2014). 197

Figura 149. A composição de nichos forma uma árvore de natal na vitrine da loja Anthropologie (2010) 197

Figura 150. Prateleiras ajudam a expor os produtos na vitrine da loja Fendi em Tókio....................198

Figura 151. Vitrine com prateleiras pendentes da loja Megan Park na Austrália.. 198

Figura 152. Prateiras de apoio das bolsas parecem derreter, assumindo papel decorativo na vitrine da loja Louis Vuitton em Zurique 199

Figura 153. Prateleiras em formato de nuvem da loja Cosas de Lu em Almenara (Espanha)...........199

Figura 154. Manequins Infanto-juvenis da loja da Gap ............................................................202

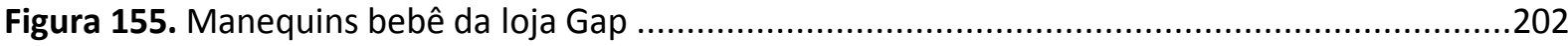

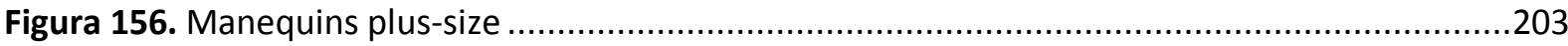

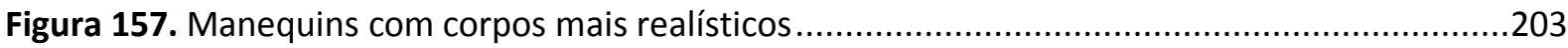

Figura 158. Manequim com escoliose na vitrine da loja Modissa em Zurique ...............................203

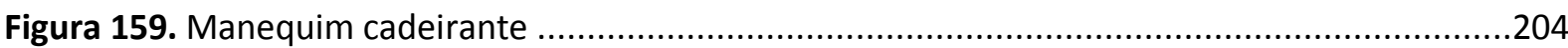

Figura 160. Manequim baseado na pessoa de cadeira de rodas ..................................................204

Figura 161. Manequim baseado na mulher com escoliose...........................................................205

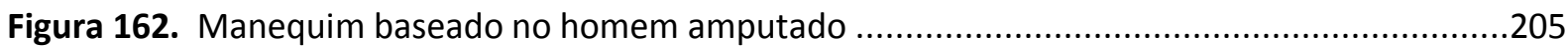

Figura 163. Manequins com pernas extremamente longas da loja Bergdorf Goodman...................205

Figura 164. Manequins com braços extremamente longos da loja Louis Vuitton ............................205

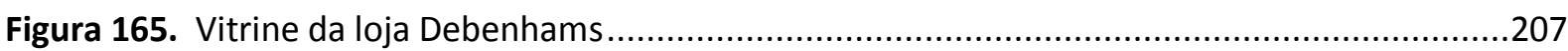

Figura 166. Exemplo de aplicação da marca Chuvisco em diversas possibilidades ..........................209

Figura 167. Sinalização com impressão digital e iluminação Front Light..........................................212

Figura 168. Sinalização com impressão digital da loja LoveToys da Oscar Freire - São Paulo...........212

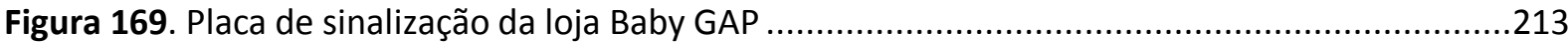

Figura 170. Placa de sinalização da loja Ri Happy de Florianópolis.................................................214 


\section{LISTA DE QUADROS}

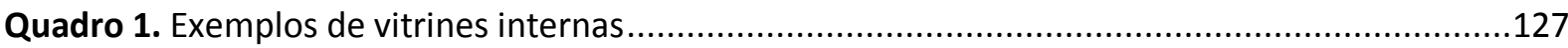

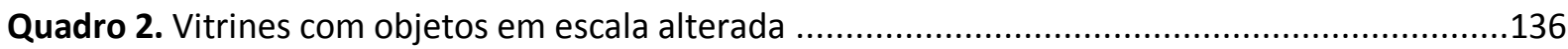

Quadro 3. As diferentes fachadas da Galeria Melissa ao longo da última década ...........................151

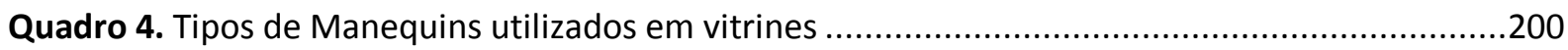

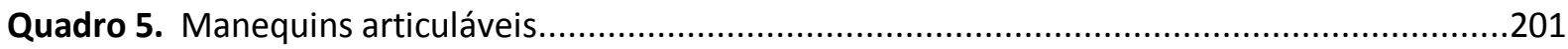

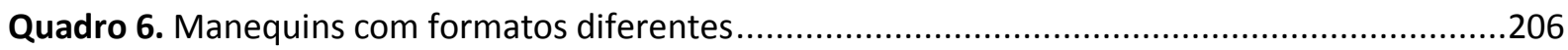

Quadro 7. Letras caixas de lojas da Oscar Freire - São Paulo .............................................................210

Quadro 8. Letras caixas fixadas diretamente sobre os vidros de vitrines de lojas da Oscar Freire - São

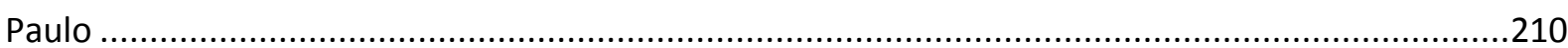

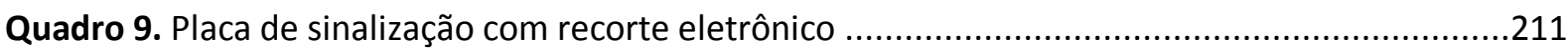

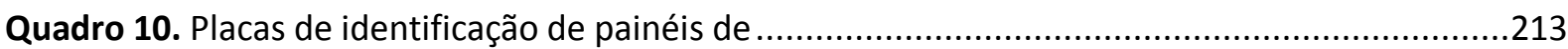

\section{LISTA DE TABELAS}

Tabela 1. Quadro comparativo dos diferentes tipos de bens de consumo .......................................73

Tabela 2. Mudanças do perfil dos espaços comercias ao longo das últimas décadas .......................105

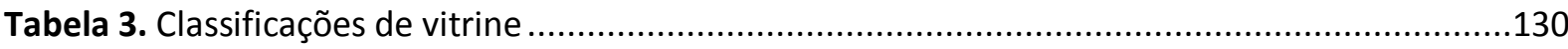

Tabela 4. Índice de Reprodução de Cores e exemplos de aplicação ...............................................178

Tabela 5. Nível de Iluminância para Lojas ...................................................................................179 


\section{SUMÁRIO}

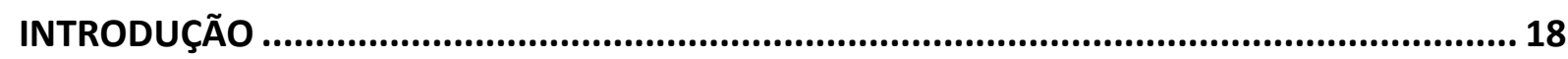

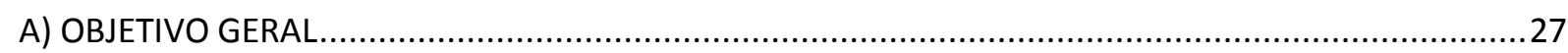

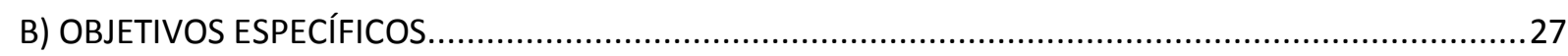

Capítulo 1 - Paisagem urbana, Comércio e Comunicação Visual ............................................. 29

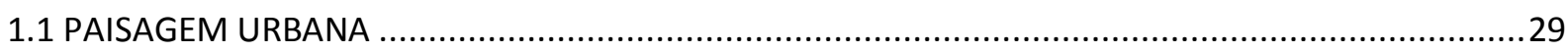

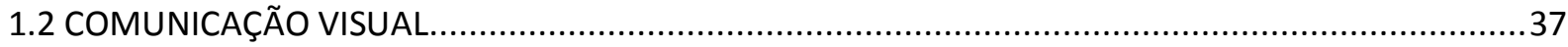

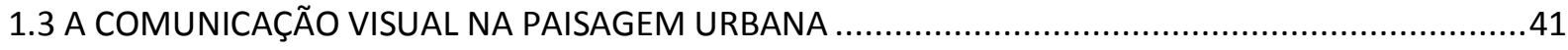

Capítulo 2 - Comportamento do Consumidor........................................................................ 48

2.1 OS PRINCIPAIS FATORES QUE INFLUENCIAM NO PROCESSO DE COMPRA ...............................53

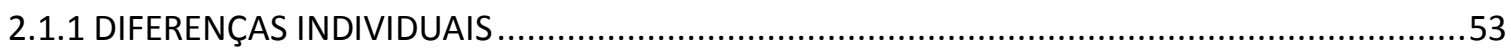

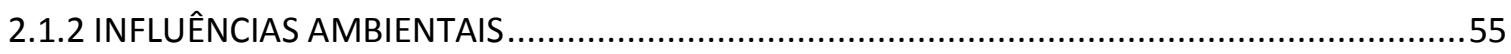

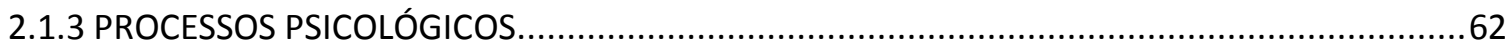

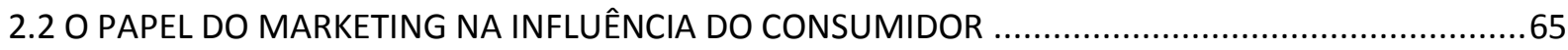

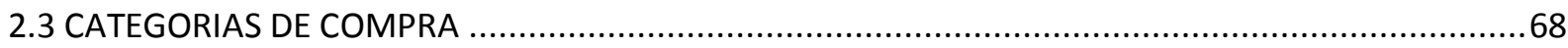

2.4 O SUJEITO PÓS-MODERNO E O CONSUMO: OS REFLEXOS DA SOCIEDADE PÓS-MODERNA NO

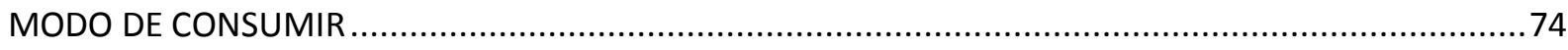

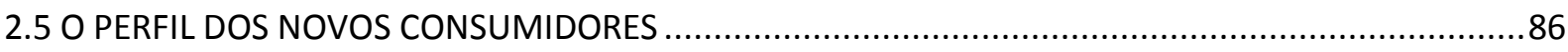

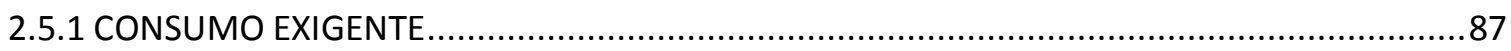

2.5.2 CONSUMO +60 


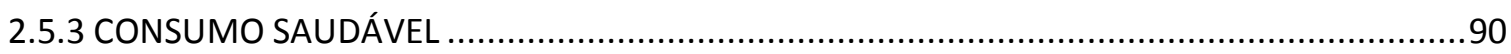

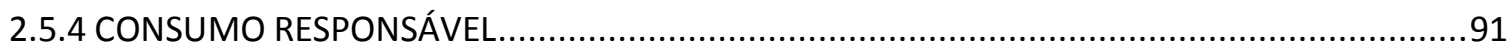

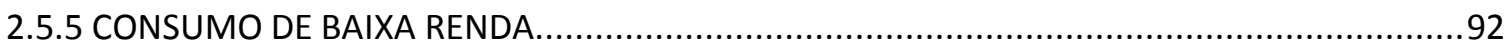

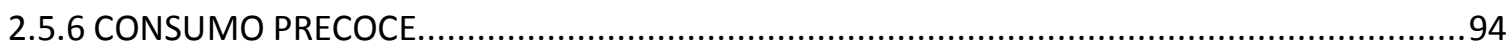

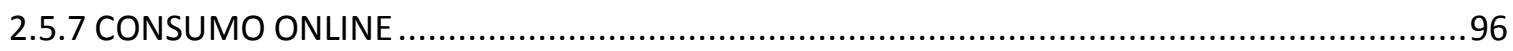

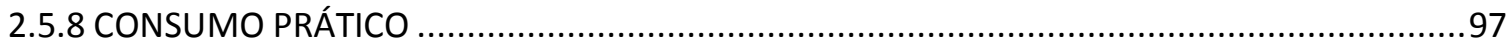

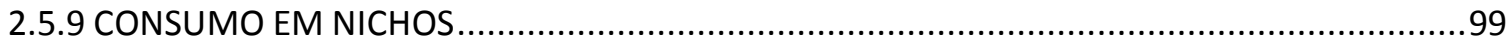

Capítulo 3 - Arquitetura comercial e as vitrines ............................................................... 103

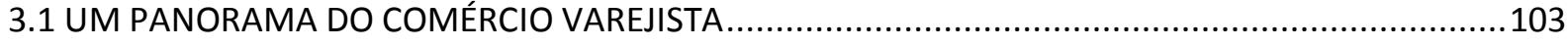

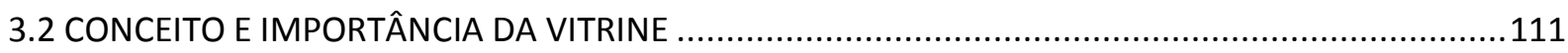

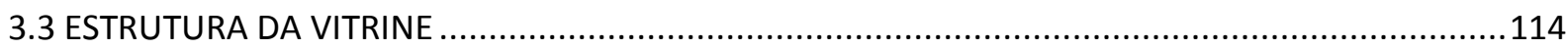

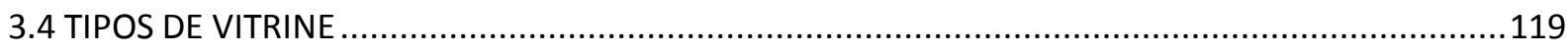

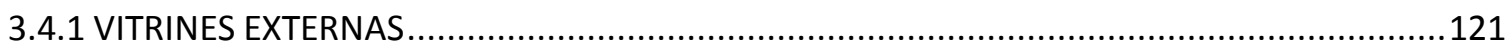

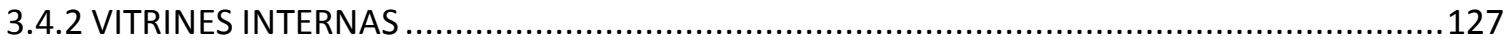

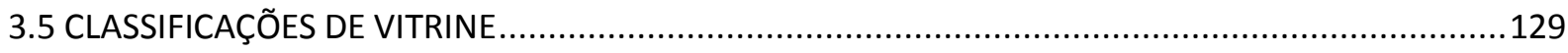

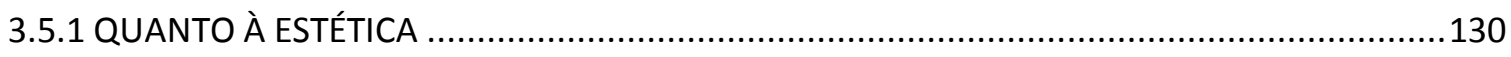

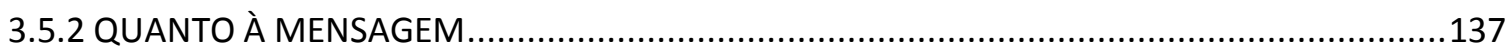

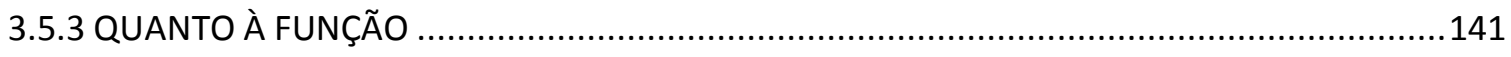

Capítulo 4 - Design Visual e Fachadas Comerciais ......................................................... 143

4.1 ARQUITETURA DAS LOJAS: NOVAS CATEGORIAS PARA O SÉCULO XXI ...................................144

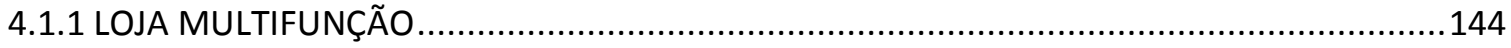

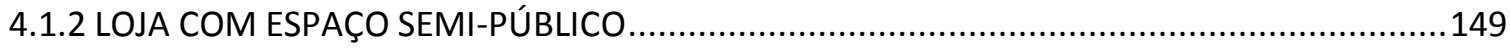

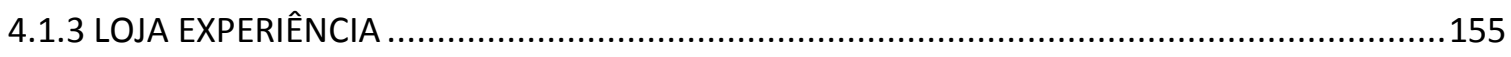

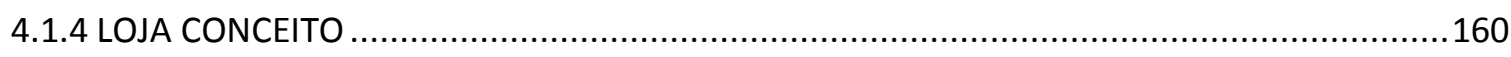

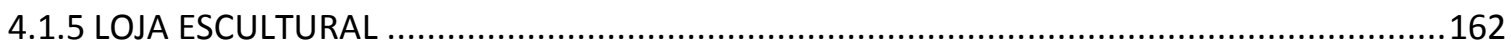

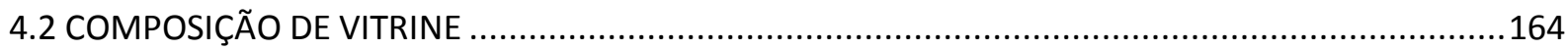

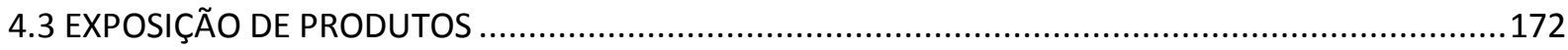




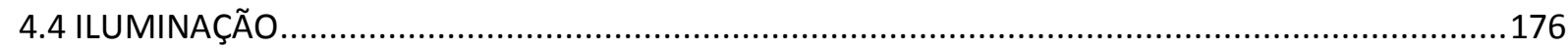

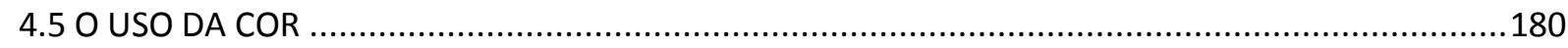

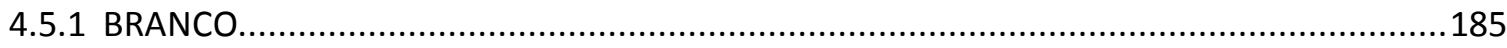

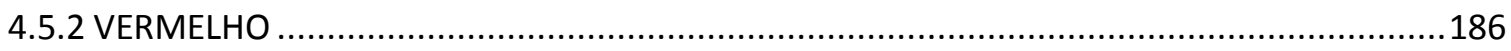

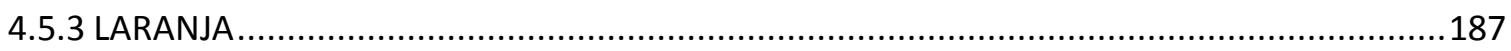

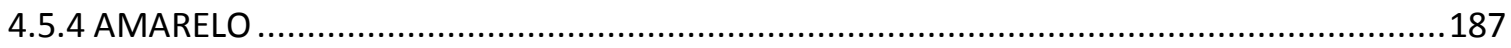

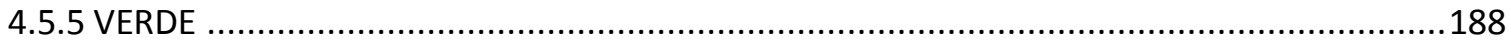

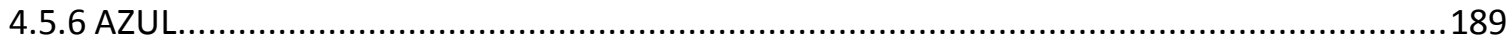

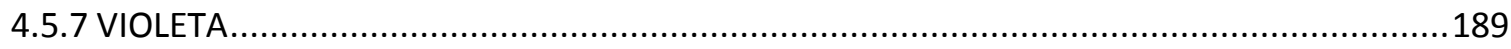

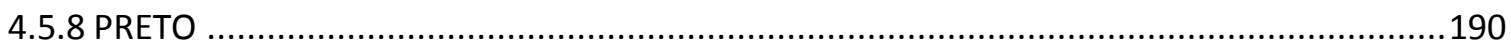

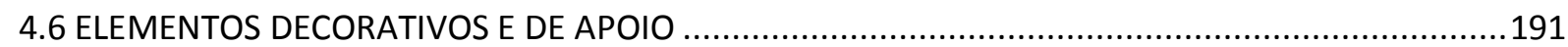

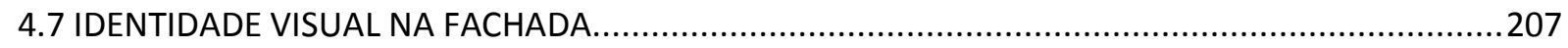

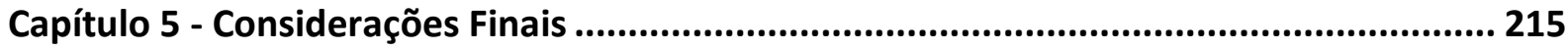

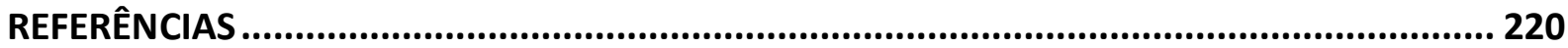




\section{INTRODUÇÃO}

Merchandising visual é um tema relativamente novo no Brasil e muito pouco explorado em projetos arquitetônicos de forma consciente. Desta forma, faz-se necessário compreender o conceito, para que se possa aplicálo de maneira correta.

Segundo Blessa (2001) merchandising visual é a:

técnica de trabalhar o ambiente do ponto-de-venda criando identidade e personificando decorativamente todos os equipamentos que circundam os produtos. $O$ merchandising visual usa o design, a arquitetura e a decoração para aclimatar, motivar $e$ induzir os consumidores à compra. (BLESSA, 2001, p. 22)

De forma concordante Levy e Weitz (apud SERRALVO, 1993, p.72) definem merchandising visual por "toda comunicação com o consumidor, por meio de símbolos, exposições e efeitos especiais, no interior das lojas ou das vitrines, para informar e sugerir ao consumidor a compra de um ou mais itens".

O merchandising visual consiste em uma das ferramentas do design visual, que objetivam propiciar uma promoção adequada da imagem da empresa e melhor visibilidade ao produto. Numa tradução literal, merchandising visual é definido por comercialização visual, o que implica numa busca visual em tornar comerciável, ou seja, fazer entrar no processo de distribuição comercial um produto ou marca. 
Com isso, há de se ter uma preocupação com toda a imagem e comunicação da loja, envolvendo tudo o que os consumidores pensam sobre ela. Não basta pensar apenas nas mesmas táticas para criar e ajustar a imagem de um ambiente comercial. Tem-se que considerar toda a percepção que o público tem de um determinado tipo de loja de acordo com o local onde está inserido, o tempo e a sociedade que pertence. (CHURCHILL e PETER, 2005, p. 430).

Neste sentido o marketing vem para complementar tal pensamento. Diferente do que muitos imaginam marketing não é somente propaganda, publicidade e vendas. Marketing visa administrar todas as variáveis que interferem de forma direta e indireta, na relação do produto com o mercado.

Através do mix de marketing ou composto mercadológico, o marketing busca constituir um conjunto de políticas de mercado, para que a empresa possa criar, melhorar ou cristalizar uma percepção positiva do mercado em relação ao seu produto. Tudo isso é obtido com o auxílio de quatro grandes políticas de mercado conhecidas mundialmente como 4Ps do Marketing: Produto (Product), Preço (Price), Praça (Place) e Promoção (Promotion).

Para o visual merchandising, a política de mercado mais importante é a praça, já que esta é a que define o ponto comercial, local onde ocorrerá o contato do público com o produto/marca. Nesta política de mercado, o local, posição geográfica, é a decisão mais importante a ser tomada.

Mas não basta uma localização adequada, sem um projeto arquitetônico bem estruturado. Ao se projetar um ambiente comercial KOTLER (1978) acredita na necessidade em se:

produzir efeitos cognitivos específicos e/ou emocionais sobre o mercado-alvo, utilizando-se de elementos visuais para projetar essa atmosfera, que incluem a estrutura exterior, o espaço interior, os displays, e a apresentação do pessoal da organização.(KOTLER, 1978, p.233)

Um projeto de ambiente comercial deve então considerar três pontos principais (Levy e Weitz, 2000): 
- Atmosfera da loja: Ela precisa ser consistente com a imagem da marca e com a estratégia geral. Pois, os clientes consideram difícil julgar a mercadoria com precisão se o ambiente físico for inconsistente com a mercadoria ou com os preços.

- Influência nas decisões de compra: Entender como se dá a dinâmica da compra após que o cliente entra loja. A partir disso, buscar a melhor solução para disposição das mercadorias em locais que facilitem as compras.

- Produtividade de espaço: Avaliar número de vendas geradas por cada metro quadrado da loja.

Torna-se evidente a necessidade de planejar em detalhes toda esta atmosfera de compra, ou seja, comunicação externa, layout, iluminação, mobiliário, cores, aromas e sons para que cada um desses itens proporcione a identidade da loja e comunique a que público e segmento a loja é dirigida.

É necessário que se entenda que a arquitetura comercial é o melhor meio de comunicação com o consumidor. Como bem define UNDERHILL (2009):

O prédio, a locação, tornou-se um grande anúncio tridimensional de si mesmo. A sinalização, a posição dos mostruários, o espaço para as gôndolas e para o mobiliário de loja, tudo isso faz aumentar ou diminuir a probabilidade de o shopper comprar determinado item (ou qualquer item). A ciência das compras foi desenvolvida para que pudéssemos saber como usar todas essas ferramentas. Como criar cartazes que as pessoas leiam. Como se assegurar de que todas as mensagens estejam no local apropriado. Como criar mostruários que os shoppers possam manipular com facilidade e conforto. Como assegurar que os shoppers percorram - e desejem percorrer - todos os cantos da Ioja. (UNDERHILL, 2009, p.28):

Uma arquitetura comercial diferenciada, pode muitas vezes funcionar como o próprio anúncio do negócio. A utilização do próprio edifício como uma verdadeira vitrine, incorporando elementos de publicidade, seria uma forma eficaz de controle da paisagem urbana e da própria otimização do mercado pela oferta de espaços de compras mais agradáveis. 
O comércio comunica-se com o público através da cidade por meio de três maneiras. A primeira refere-se à publicidade realizada nos próprios estabelecimentos de comércio varejista, principalmente nas fachadas, a segunda refere-se ao uso da própria arquitetura como vitrine e a terceira é a mídia externa - outdoors e materiais de propaganda em geral (VARGAS, 2001).

A arquitetura da loja, em particular sua fachada frontal, deve ser projetada visando à gestão da marca e a relação desta com o público. Tem-se que pensar na arquitetura não apenas como mero caixote para anteparo da comunicação visual (Figura 1). Há de se pensar em arquitetura enquanto composição, estilo, harmonia, coerência com o entorno. E no que diz respeito à arquitetura comercial, deve-se acrescentar mais duas variáveis dominantes, o público alvo e a gestão da marca.

Figura 1. Shopping lguatemi de Florianópolis, mais um caixote comercial

Fonte:

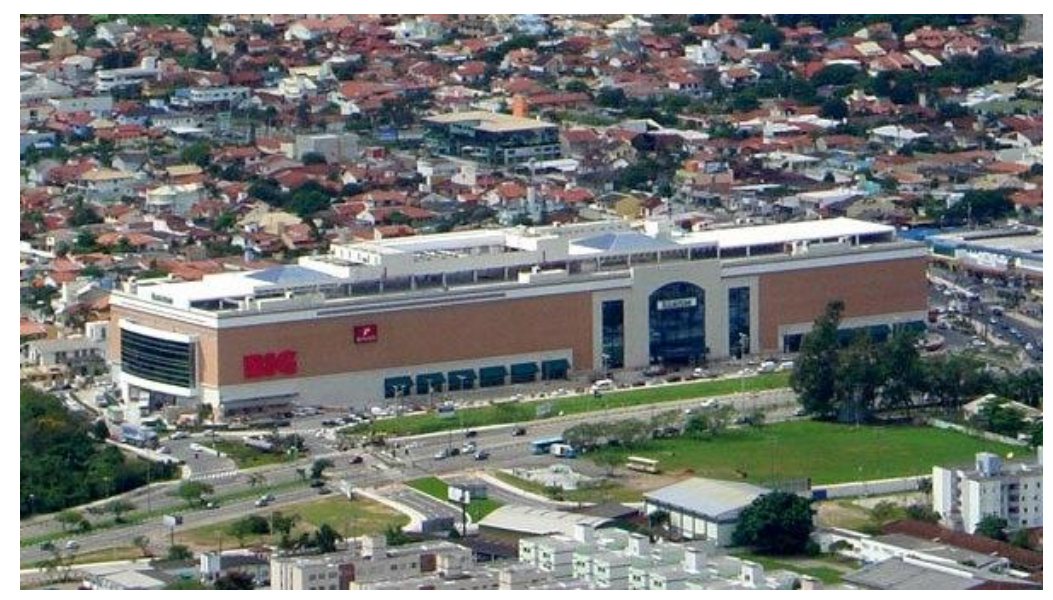

A possibilidade de facilmente alterar a fachada e integrá-la a concepção da marca (Figura 2 e Figura 3) é um fator que deve ser considerado no projeto. Quanto mais alinhada à identidade visual da marca e mais dinâmica for a arquitetura da loja, produziremos uma arquitetura mais rica em signos e deixaremos de produzir meramente mais um espaço descaracterizado. 


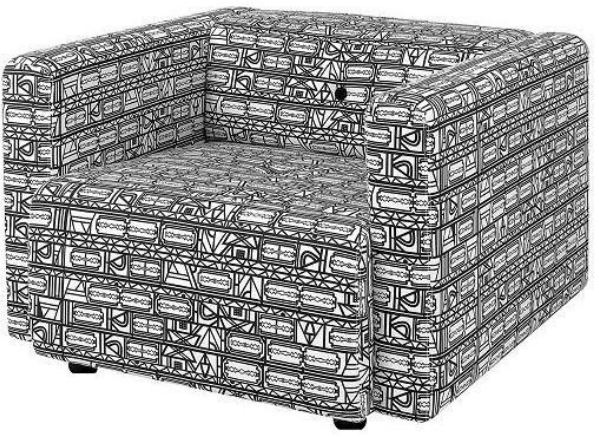

Figura 2. Estampa desenvolvida pelo estilista Alexandre Herchcovitch Fonte: http://monicabarbosa.com.br/?p=3323

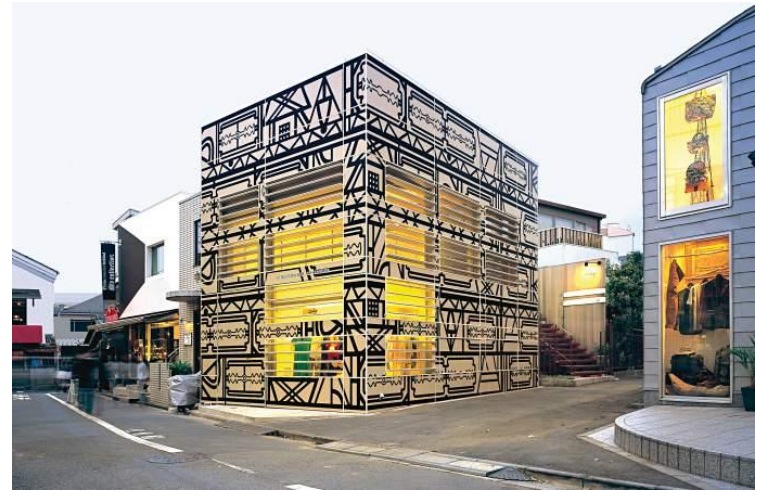

Figura 3. Loja do Alexandre Herchcovitch - Tóquio. Fonte: http://www.arcoweb.com.br/arquitetura/studio-arthurcasas-loja-toquio-05-08-2008.htm/

Com isso estaremos reforçando a imagem da empresa, o projeto atrairá mais atenção do público, e, por conseguinte, do consumidor. Viebig (2005) relata que a imagem de uma empresa junto ao mercado ultrapassa valores puramente estéticos. A personalidade, traduzida na imagem (marca/símbolo/logotipo), ganha importância fundamental a partir da constatação de sua existência de forma planejada, abrangendo as várias extensões de relacionamento da empresa.

Deve-se ainda planejar a arquitetura da loja para dois momentos distintos: enquanto aberta e fechada. Uma loja deve se comunicar com o público e interagir com a cidade, independente do seu horário de funcionamento. Desta forma, pensar em um projeto no momento em que a loja se encontra fechada é no mínimo já ultrapassar a mesmice das mesmas grades e portões tão utilizados para realizar o fechamento destas.

Fica clara a importância da arquitetura como anteparo de outras ciências, entre elas a ciência do consumo. Podendo influenciar diretamente não só na qualidade espacial da cidade, mas também diretamente a economia e a forma de consumo da sociedade. Entender esta nova sociedade consumista e sua relação com o espaço é de fundamental importância para o desenvolvimento urbano. Lipovetsky (2007) traduz tal situação como:

Numa época em que as tradições, a religião e a política são menos produtoras de identidade central, o consumo encarrega-se cada vez melhor de uma nova função identitária. (LIPOVETSKY, 2007. p.44). 
Pensar numa arquitetura comercial adequada a esta função é trazer mais qualidade ambiental urbana dos centros terciários, melhorando questões como a poluição visual, dificuldade de orientação, dificuldade de deslocamento nas ruas e nas calçadas, por uso indevido das mesmas.

Aliado a isso, conciliar parâmetros pertinentes ao design visual no momento em que o arquiteto está projetando é uma maneira de trazer qualidade espacial para o ambiente comercial.

Quando a arquitetura deixa de ser encarada como uma ciência meramente funcional com valores estéticos, como "a arte e técnica de organizar espaços e criar ambientes para abrigar os diversos tipos de atividades humanas, visando também a determinada intenção plástica” ${ }^{1}$, e passar a ser vista como um anteparo e conjunto de outras ciências, seus valores podem ser ampliados e profundamente explorados. Com esse novo enfoque, as interações comunicativas constituem a matéria-prima de uma arquitetura organizacional que deverá ser vista como parte integrante de todo o sistema de comunicação, visando informar, motivar e integrar os diferentes campos de estudos.

Neste sentido, o objeto geral deste estudo são as fachadas de ambientes comerciais e a forma como ocorre a apropriação destas por parte do design visual. Neste sentido, torna-se imprescindível que se perceba que a busca pela utilização destas ferramentas para projetar estes ambientes é uma tentativa de maior conexão com o consumidor. Buscar entender quem é este sujeito e a sociedade ao qual está inserido, bem como seus anseios e relações com o consumo, é a base fundamental para o aprofundamento desta pesquisa.

Desta forma, este estudo se baseia na determinação de parâmetros de design visual aplicados em projetos comerciais e é devido a esta relação proveniente das diferentes esferas, que se tornou necessária a realização de um estudo multidisciplinar, que abrangesse a arquitetura, design, publicidade, sociologia, entre outros. Tal estudo foi feito através de

\footnotetext{
${ }^{1}$ Definição de Arquitetura do Dicionário HOUAISS da Língua Portuguesa. Ed. Objetiva, 2007.
} 
amostragem, com o intuito de prover uma análise multivariada, para determinar quais fatores possuem maior influência na composição destes ambientes comerciais, não havendo uma preocupação em se fazer um recorte de apenas ambientes comerciais brasileiros, pois o fator primordial era relevância e qualidade do design visual aplicado a estes ambientes, não importando sua localização.

Tratando-se de um estudo exploratório, iconográfico e documental, com o intuito de identificar elementos de design visual aplicados a ambientes comerciais, a metodologia consistiu basicamente na leitura da bibliografia selecionada e em visitas ao campo de estudo. Por tal motivo, foi feito um levantamento bibliográfico mais acurado; de leituras de artigos e livros de reconhecidos especialistas, tal como entrevistas, palestras e cursos sobre o design visual. Esta complementação do levantamento bibliográfico teve por objetivo criar uma proximidade ainda maior com o tema de estudo, proporcionando uma base teórica consolidada, para, a partir disso, ser possível selecionar exemplos de arquitetura comerciais que fossem referência na implantação de parâmetros de design visual.

Além disso, foram realizadas visitas aos bairros de São Paulo, com o intuito de fazer um levantamento descritivo mais preciso dos conjuntos comerciais, obtendo uma compreensão visual e prática das teorias estudadas. Devido à falta de conjuntos significativos pela cidade, optou-se por delimitar o campo da pesquisa em projetos pontuais, que permitissem uma leitura esclarecedora e reflexiva do objeto desta pesquisa.

Após esta delimitação, foi feita uma análise das tipologias dos edifícios, com enfoque nas fachadas, sua relação com a marca/produto neste comercializada, sua identidade visual e interação com o consumidor.

A partir dessas variáveis selecionadas foram desenvolvidos alguns agrupamentos no intuito de apontar parâmetros de projeto, que melhorem o desempenho dos ambientes comerciais e sua relação com a marca, catalogando as diversas soluções projetuais onde fora praticado o design visual, visando estabelecer parâmetros para futuros projetos e qualificação dos já existentes. 
Para expor tais questões, a dissertação está dividida em 5 capítulos. No capítulo inicial será abordada a comunicação visual, sua relação com a cidade e o comércio. Serão discutidos conceitos importantes ligadas a paisagem urbana como meio de comunicação, baseando-se em autores clássicos, como Kevin Lynch, Françoise Choay e Gordon Cullen. No item 1.2 o centro da discussão é a mídia exterior, sua capacidade de transmitir mensagens e as diversas formas que estas assumem. Busca-se, desta maneira, levantar questionamentos acerca do modo como a comunicação visual se comunica com o usuário, de modo a criar uma ponte para compreender quais os mecanismos utilizados pelos ambientes comerciais para estabelecerem um sistema de comunicação com o consumidor, que serão explanados no item 1.3. Assim, o item 1.3 será destinado a explicar as aplicações da comunicação visual na paisagem urbana, sua forma de inserção na cidade, garantindo um trânsito informacional da cidade com o usuário.

No capítulo 2 será abordado o comportamento do consumidor, com foco nos fatores que influenciam o indivíduo no processo de compra. Será apresentada a forma como ocorre os processos de decisão que moldam os padrões de compra e consumo, com o objetivo de ajudar a desenvolver uma visão geral do comportamento do consumidor, que posteriormente permitirá compreender os reflexos disso nas estratégias utilizadas pelos estabelecimentos comerciais. Além disso, no item 2.2 será abordado o papel do marketing na influência do consumidor e no item seguinte é feita uma descrição das principais categorias de compra, buscando identificar as práticas e hábitos de consumo.

Como é imprescindível que se explane acerca da relação da arquitetura com o consumo e principalmente, com o consumidor, uma vez que esta relação só se torna possível devido à existência do mesmo, busca-se no item 2.4 entender quem é este consumidor, esclarecendo os conceitos que permeiam a sociedade pós-moderna, seus anseios e impactos sobre a forma de consumir. 
Por fim, no último item do capítulo 2 é traçado um perfil dos novos consumidores, elencando algumas perspectivas para o consumo até 2030. O objetivo principal deste capítulo é permitir reflexões sobre o comportamento do consumidor, ajudando a desenvolver uma noção da complexidade dos processos decisórios e das muitas implicações resultantes disso.

No capítulo 3 serão abordadas as adaptações e estratégias realizadas pela atividade comercial e sobre a transformação dos estabelecimentos comerciais ao longo do século XX para o século XXI, evidenciando a mudança no caráter de lugar de mercado para espaço de consumo e de consumo do lugar. Bem como, se buscará explanar a respeito das características dos estabelecimentos comerciais, como uma arquitetura que busca reinventar o urbano e a tendência do retorno às ruas, ao centro e à arquitetura pré-existente.

Nos demais itens deste capítulo serão apresentados o conceito e importância das vitrines para a arquitetura comercial, algumas definições e categorizações de fachadas comerciais, enquanto tipos de vitrine, estrutura e por fim as classificações segundo à estética, à mensagem e à função apresentada.

No capítulo 4 serão abordados princípios do design visual aplicados a fachadas comerciais, enquanto composição, disposição de produtos, mobiliário, comunicação visual, entre outros. O objetivo é apresentar as principais formas de aplicação do design visual em estabelecimentos comerciais varejistas. Para elucidar tais aplicações serão apresentados exemplos que facilitem a compreensão visual de tais categorias. Tais exemplos serão escolhidos de forma a poder comparar as principais referências estudadas com as soluções encontradas em São Paulo.

No capítulo final será feita uma síntese dos elementos constantes na dissertação, bem como uma análise dos resultados obtidos através dos estudos e investigações realizadas nesta pesquisa. Serão elencados os principais parâmetros pertinentes ao design visual aplicados em estabelecimentos comerciais, identificando possíveis elementos 
estruturadores de projeto e apontando potencialidades e contribuições deste tipo de interação do campo do design com a arquitetura. Por fim, pretende-se indicar sugestões para possíveis desdobramentos desta pesquisa.

\section{A) OBJETIVO GERAL}

Identificar parâmetros pertinentes ao design visual aplicados em fachadas de estabelecimentos comerciais e sua relação com o espaço da cidade, bem como as influências do comportamento de consumo do sujeito pósmoderno na concepção destes espaços.

\section{B) OBJETIVOS ESPECÍFICOS}

1. Investigar os conceitos relativos a sociedade pós-moderna, principalmente no que tange ao modo de consumir;

2. Selecionar referências de arquitetura comercial que tiveram parâmetros do design visual aplicados ao projeto;

3. Fazer um levantamento de ambientes comerciais de São Paulo que possam servir de exemplos;

4. Avaliar as potencialidades e limitações da aplicação dos elementos do design visual em arquiteturas comerciais;

5. Analisar as relações entre a tipologia dos estabelecimentos comerciais selecionados e a relação com a marca comercializada neste ambiente;

6. Comparar as referências estudadas com as soluções empregadas em São Paulo; 
7. Investigar quais elementos do design visual aplicados em projetos de arquitetura comercial possam ser considerados elementos estruturadores de projeto;

8. Catalogar as diversas soluções projetuais onde fora praticado o design visual, visando estabelecer parâmetros para futuros projetos e qualificação dos já existentes. 


\section{Capítulo 1}

\section{Paisagem urbana, \\ Comércio e \\ Comunicação Visual}

\subsection{PAISAGEM URBANA}

A paisagem é tudo aquilo que é percebido pelos nossos sentidos e por isso, se torna única para cada pessoa, pois depende da dimensão da percepção individual. De acordo com Santos (1991), uma paisagem é um conjunto de objetos que geralmente tem idades diferentes, sendo resultado da junção de diferentes momentos. Pode ser interpretada como uma combinação dinâmica, inter-relacionada e interdependente de elementos naturais e antrópicos, que em determinado tempo, espaço e momento social formam um conjunto único e indissociável, que podem estar em equilíbrio, gerando uma estética em unidade (HARDT, 2000).

Desta forma, a paisagem urbana é o reflexo da relação entre o homem e a natureza. Segundo Cullen (1984), a paisagem urbana é a arte de tornar coerente e organizado, visualmente, o emaranhado de edifícios, ruas e espaços que constituem o ambiente urbano. 
O modo como a paisagem é projetada e construída reflete uma cultura que é o resultado da observação e, principalmente, da experiência individual ou coletiva que se tem no ambiente. Assim, as paisagens urbanas não devem ser percebidas somente por meio daquilo que vemos, mas por meio de como nos identificamos ou sentimos. Isso porque a imagem é formada pelo conjunto de sensações experimentadas ao observar e viver em determinado ambiente. $E$ consequentemente, as imagens do meio ambiente resultam desta relação entre o observador e seu meio. Porém, o sentido dado ao que se vê pode variar entre diversos observadores e estas diferenças estão interligadas as características individuais, mas também a fatores sociais e culturais (LYNCH, 1999).

A imagem da cidade guarda em si um significado de apelo não somente visual, mas fundamentalmente desenvolve um sentido de lugar. Segundo Lynch (1999, p. 134): "Esse sentido de lugar realça todas as atividades humanas que aí se desenvolvem e estimula o depósito de um traço de memória".

Esta imagem da cidade é em grande parte influenciada pela arquitetura de edifícios voltados para o setor terciário da economia, que promove, de certa maneira, uma visão oficial da sociedade. Portanto, a paisagem urbana é um dos elementos de vital importância para o entendimento das cidades e de sua estrutura, e consequentemente, dos ambientes comerciais.

É através das construções, que as marcas do tempo se exprimem, revivendo lembranças que ali são identificadas A paisagem urbana revela-se repleta de vida, sendo, portanto, resultado de ações coletivas produzidas pela sociedade, unindo num mesmo lugar o espaço construído ao movimento da vida. Moreira (1988) reforça este pensamento ao definir a paisagem urbana como um mosaico de formas com funções variadas, que nos permite uma leitura em escalas diversificadas.

O espaço construído é o concretamente visível, o que primeiro se percebe numa cidade. Os prédios, casas, lojas, ruas e bairros se apresentam com configurações diferentes, possuindo características próprias a cada realidade que se inserem (CARLOS, 1992). Agregado a isto há o movimento 
peculiar à paisagem urbana, gerado pelo deslocamento das pessoas, que torna esta paisagem única.

Segundo Minami e Guimarães Júnior (2001) embora a funcionalidade seja a característica mais evidente quando se trata de uma cidade, o espaço urbano deve ser concebido para exercer além de funções eficientes de moradia, trabalho, circulação e lazer, mas também se deve considerar a função estética, com o objetivo de proporcionar sensações visualmente agradáveis às pessoas.

Isso porque, é através da paisagem urbana que as cidades se conectam aos seus habitantes e visitantes. Para Silva (1997):

a boa aparência das cidades surte efeitos psicológicos importantes sobre a população, equilibrando, pela visão agradável e sugestiva de conjuntos e elementos harmoniosos, a carga neurótica que a vida cotidiana despeja sobre as pessoas que nela hão de viver, conviver e sobreviver. (SILVA, 1997, p.273)

Morar em uma cidade agradável e bela é um interesse comum da população, pois a qualidade de vida e o seu bem-estar estão diretamente ligados à estética da paisagem urbana. Tal como, o potencial turístico das cidades, que se torna exponencialmente maior, conforme a beleza de sua paisagem, sua conservação e manutenção.

A paisagem da cidade deve evocar emoções positivas em seus usuários, para que estes se sintam parte da paisagem. Se uma cidade se apresenta "monótona, incaracterística ou amorfa, ela não cumpre a sua missão" (CULLEN, 1984, p.10).

Lynch (1999) acredita que uma boa imagem da cidade oferece reforça a profundidade e intensidade da experiência e a ação humana. Para ele, a organização visual de um ambiente, tornando-o nitidamente identificado, permite ao cidadão introduzir seus próprios significados e relações, tornado a cidade um "verdadeiro lugar, notável e inconfundível".

A clareza da paisagem urbana, ou seja, sua legibilidade, é um fator marcante para o entendimento da cidade. A identificação por parte de 
todos os seus agentes de suas próprias características e de sua própria organização segundo um determinado padrão, indica a facilidade de leitura da cidade. Um ambiente de fácil leitura é, então, um ambiente com boa legibilidade, de fácil identificação.

Para Choay (2000, p.309) uma cidade será legível quando seus "bairros, ou monumentos, ou vias de circulação são facilmente identificáveis e facilmente integráveis dentro de um esquema global". Desta forma, embora a legibilidade não seja o único atributo importante de uma bela cidade, este é um fator muito importante para a organização e o entendimento destas, e fundamental para o cenário urbano. O usuário precisa ler o ambiente em que se insere em busca de referências e orientações, o que o ajuda a construir uma percepção sobre o espaço.

Esta leitura do ambiente ocorre através de processos de estruturação e identificação, que para Lynch (1999) são capacidades vitais dos seres que se locomovem. Para isso, muitos tipos de indicadores são usados: as sensações visuais de cor, forma, movimento ou polarização da luz, além de sentidos como olfato, audição, tato, a sinestesia, o sentido da gravidade e talvez dos campos elétricos e magnéticos. Assim, no processo de orientação, "o elo estratégico é a imagem ambiental, o quadro mental generalizado do mundo físico exterior de que cada indivíduo é portador". (LYNCH, 1999, p.4).

Assim Lynch (1999) atenta para a importância da clareza no ambiente urbano. Uma imagem ambiental clara facilita o conforto e a rapidez nos deslocamentos, além de proporcionar um importante sentimento de segurança:

A necessidade de reconhecer e padronizar nosso ambiente é tão crucial e tem raízes tão profundamente arraigadas no passado, que essa imagem é de enorme importância prática e emocional para o indivíduo.

Sem dúvida uma imagem clara nos permite uma locomoção mais fácil e rápida: encontrar a casa de um amigo, um policial ou um armarinho. Contudo, um ambiente ordenado pode fazer mais do que isso; pode servir como um vasto sistema de referências, um 
organizador da atividade, da crença, ou do conhecimento. (LYNCH, 1999, p. 4)

O homem precisa ler o ambiente no qual está inserido em busca de referências e orientação, pois é através da leitura que ele irá construir uma percepção sobre o espaço. É a relação que o indivíduo mantém com o ambiente que irá influenciar de maneira impactante na sua forma de uso, na apropriação de significados e na sua valorização.

Dentro do entendimento das cidades, a imagem e o significado são questões importantes. Lynch (1999) acredita que uma imagem ambiental pode ser decomposta em três componentes: identidade, estrutura e significado. Tem-se por identidade, o sentido de singularidade, de identificação do objeto, sua diferenciação perante outras coisas e seu reconhecimento enquanto uma entidade separável individual. Assim, um objeto ou lugar que apresenta uma boa imagem é também aquele apreendido pelo usuário como único, que se diferencia facilmente de outros por características próprias e singulares. No que diz respeito à estrutura, a imagem refere-se à relação espacial e interação com o usuário ou à relação prática do objeto com o observador e outros objetos. Por último, esse objeto, ou lugar, deve ter algum significado para o observador, seja ele prático ou emocional.

Neste sentido, Lynch (1999) e Choay (2000), mostram-se em concordância ao afirmar que a imagem da cidade deve ser clara do ponto de vista prático e que permita ao indivíduo atuar a vontade dentro do campo do seu meio ambiente. Desta forma, para facilitar a orientação dentro da paisagem urbana, a imagem da cidade deve possuir um número suficiente de pontos de referência que permitam ao indivíduo uma escolha com o mínimo de segurança. Além de permitir que o indivíduo construa sua própria realidade, ou seja, que esta seja aberta e adaptável a mudanças. Para Choay (2000) estas não as únicas qualidades que a imagem deve possuir:

Para facilitar a orientação dentro do espaço de comportamento, a imagem deve possuir várias qualidades. Deve ser suficientemente exata do ponto de vista pragmático e permitir que o indivíduo atue a vontade dentro do campo de seu meio ambiente. $O$ 
plano, exato ou não, deve permitir que se volte para casa. Deve ser bastante claro e bem integrado para poupar os esforços mentais. (CHOAY, 2000. p.311)

Tendo em vista esta imagem da cidade, mutável e complexa, a imaginabilidade ganha destaque, devido sua relevância e necessidade de identidade e estrutura em nosso mundo perceptivo. Um ambiente belo tem várias propriedades básicas, como significado ou expressividade, prazer sensorial, ritmo, estímulo, escolha e a imaginabilidade, que é uma qualidade física relacionada aos atributos de identidade e estrutura na imagem mental. Esta é uma característica que confere uma alta probabilidade de evocar uma imagem forte em qualquer observador. Nas palavras de Lynch, "é aquela forma, cor ou disposição que facilita a criação de imagens mentais claramente identificadas, poderosamente estruturadas e extremamente úteis ao ambiente." (LYNCH, 1999, p.11)

Uma cidade altamente imaginável seria convidativa ao olhar, chamaria atenção de todos os sentidos, seria expressiva, teria ritmo e traria escolha aos indivíduos. Assim, para se construir cidades onde um grande número de pessoas de formação e experiências diversas possa desfrutar - e que sejam adaptáveis ao futuro -, "devemos ter a sabedoria de nos concentrar na clareza física da imagem e permitir que o significado se desenvolva sem nossa orientação direta". (LYNCH, 1999, p.10)

O conteúdo das imagens das cidades quanto a sua forma física, são classificados por Lynch (1999) em cinco tipos de elementos: vias, limites, bairros, pontos nodais e marcos. As vias são os canais de circulação ao longo dos quais os indivíduos se locomovem. Podem ser ruas, alamedas, canais, ferrovias, etc. Já os limites são as fronteiras entre os espaços, quebras de continuidade lineares. Podem ser barreiras mais ou menos penetráveis que separam uma região da outra, mas também podem ser costuras, linhas ao longo das quais duas regiões se relacionam e se encontram. Os bairros são regiões médias ou grandes de uma cidade, caracterizada por suas extensões bidimensionais, onde o observador penetra mentalmente, e são reconhecíveis por possuírem características comuns que os identificam. Os pontos nodais são pontos estratégicos que 
possuem focos intensivos, que determinam e auxiliam na locomoção dos indivíduos. São os chamados "pontos de decisão" e podem ser junções, cruzamentos, bifurcações e convergências. É o momento de passagem de uma estrutura para outra. Por fim, os marcos são os pontos de referência externos em uma cidade. São elementos físicos que servem para localização e que nem sempre estão ali para este motivo. Podem ser desde elementos naturais, como uma montanha, ou construídos, como um obelisco.

Nenhum dos elementos citados anteriormente existe de forma isolada. Isso significa que eles não são excludentes. Um bairro é composto por pontos nodais, definido por limites e estruturado por vias, com a presença de marcos.

Dentre estes cinco elementos da imagem da paisagem, os marcos são para este estudo, os mais importantes. Este último elemento pode ser classificados em referencias espaciais permanentes ou dinâmicos, dependendo da sua permanência no tempo e no espaço.

Em geral referenciais permanentes são elementos físicos que permaneceram em um local por um período de tempo relativamente longo, sem interferência ou mudança significativa em sua aparência e atributos. É sua longevidade e permanência que permite a identificação e reconhecimento de um local. Como exemplo, temos os elementos naturais como montanhas, grandes rochas e os construídos, como torres, pontes, monumentos. São mais confiáveis para a orientação que os referenciais dinâmicos, pois estes são elementos que permanecem em um determinado local por um período de tempo relativamente curto. Sua presença pode afetar a aparência e características de um lugar e facilita sua identificação e reconhecimento.

Desta forma, num bairro ou cidade, um estabelecimento comercial pode muitas vezes se constituir num referencial permanente. Ocorrem muitos casos onde mesmo depois do estabelecimento comercial não estar mais em atividade, este continuar por anos ainda funcionando como um referencial para os usuários da cidade. Um exemplo é o edifício do Bingo da Imperatriz (Figura 4), que funcionou entre 2005 e 2007 na Avenida 23 de maio em São 
Paulo e mesmo após seu fechamento, continuou sendo um referencial. Em reportagem veiculada na Veja São Paulo ${ }^{2}$ em 17/07/2015 o Bingo da Imperatriz foi assim definido:

O espaço virou ponto de referência na via por ostentar em sua fachada uma estátua negra de mais de 20 metros de altura e máscaras africanas penduradas nas paredes, que já não estavam mais ali há algum tempo.

Figura 4.

Prédio do antigo Bingo da Imperatriz, que se manteve como referencial da avenida 23 de maio em São

Paulo, mesmo depois do seu fechamento em 2007.

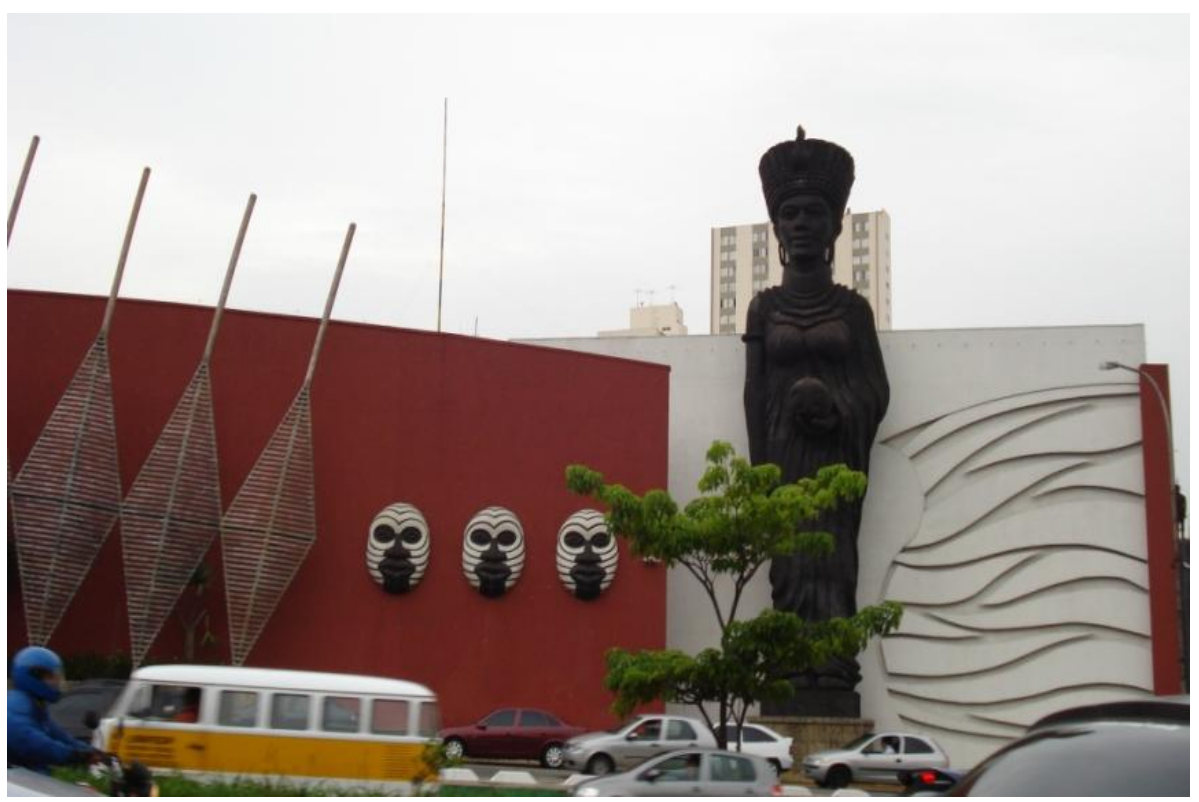

Além do estabelecimento comercial, uma campanha publicitária que utiliza grandes suportes, de mobiliário urbano e até mesmo outdoor, também pode se constituir como um referencial, mesmo que após seu período de promoção este seja removido. Neste caso o referencial é classificado como dinâmico, devido sua longevidade e permanência no espaço.

Um estabelecimento comercial também pode ser considerado um referencial dinâmico. Para tal, será determinante o tempo de permanência do estabelecimento no local e as mudanças ocorridas nas suas fachadas. Nestes casos, o referencial passa a não ser confiável, pois o grau de mudança na sua localização e seus atributos afetará a confiabilidade dos usuários para sua orientação e entendimento dos lugares.

\footnotetext{
2 Veja São Paulo. Prédio do Bingo Imperatriz virará concessionária de carros. São Paulo, 17/07/2015. Disponível em: http://vejasp.abril.com.br/materia/prediobingo-imperatriz-23-maio-concessionaria
} 


\subsection{COMUNICAÇÃO VISUAL}

Em função da necessidade do ser humano em se comunicar, instituíram-se sistemas de informação. Desde os primórdios, a comunicação visual acompanha o homem. Historicamente sempre estivemos conectados por uma forma de expressão visual, que buscava tornar gráfica a linguagem verbal, e de onde evoluiu todo um sistema de comunicação necessário ao desenvolvimento das atividades humanas.

Foi a partir das primeiras formas de expressão humana, que remetem às marcas deixadas nas paredes pelos homens das cavernas, que houve a evolução de todo um sistema de comunicação. De acordo com Minami (2001):

Seja um rabisco, um desenho, uma cor, uma letra ou uma forma qualquer em destaque, em algum lugar, a comunicação visual tem no seu próprio conceito do termo, um único e fundamental objetivo: informar algo, silenciosamente, expressando um significado, definindo um local, uma situação, dando uma orientação. (MINAMI, 2001)

Independente do tipo de comunicação visual, estas têm, em comum, a intenção de informar alguma coisa. Podem informar com persuasão, ludicamente, para prevenção, educação, ou ainda no sentido de explicar ou comunicar um novo produto (CURY, 2004.).

A comunicação visual pode ter caráter externo, denominada de comunicação exterior, que são as formas de propaganda pela qual os anúncios são vistos fora das casas dos consumidores, e interno, quando vistos dentro da casa dos consumidores (CURY, 2004).

É possível encontrar a comunicação exterior aplicadas na comunicação visual em promoção de vendas, merchandising visual, eventos, publicidade, comunicação de endomarketing ${ }^{3}$, marketing pessoal etc. Independente da aplicação, quando se fala de comunicação visual, se tem a imagem do todo

\footnotetext{
${ }^{3}$ conjunto de estratégias e ações de marketing institucional voltadas para o público interno (empregados, revendedores, acionistas, etc).
} 
e não apenas dos elementos que a constituem: o conteúdo, que é o texto e/ou imagem, sua forma, que é o tratamento dado ao conteúdo e seu suporte. Este último é o elemento que permite a materialização e funciona como apoio à peça. Segundo Cury (2004) é:

Indiscutível é a importância dos suportes na comunicação, ajudando a "vestir" embalagens, transmitir notícias impressas (papel para jornal e revista) e eletrônicas (tela da TV e da internet), recepcionar histórias e informações. Na comunicação exterior os suportes têm um significado muito especial, pela sua versatilidade ou transformismo. Espalham seus tentáculos em todas as direções do cenário da cidade e vão gerando um caótico mosaico de espaços de letras, imagens e símbolos visuais. Ora na função de bases, ora como sustentáculos das peças, ajudam a viabilizar, desde pequenos formatos, como cartazes e placas que identificam lojas, até gigantográficas como as empenas de edifícios. Permitem a produção de formatos em dimensões padronizadas (como o outdoor), e dão sustentação a criações especiais, redondas, com apliques, com partes que se movem, na forma de objetos. (CURY, 2004, p. 08)

Os suportes auxiliam na composição dos limites, indicam os eixos de direção da mensagem - frontalidade, horizontalidade, verticalidade, a natureza de sua forma - bidimensional ou tridimensional, o tipo de material e as suas dimensões.

Foi a partir da década de 1950 que a comunicação visual ganhou destaque, inserindo-se em todas as possibilidades de suportes que the fossem oferecidas para fazer com que suas mensagens chegassem ao usuário de forma cotidiana e ininterrupta (MÜLLER-BROCKMANN, 1988). Quaisquer que seja o aparato - prédios, estações de trem, ônibus, estradas, aeroportos, estádios - estes são portadores usuais de mensagens publicitárias que nos rodeiam de produtos, promoções e ideias.

Munari (2006) entende como comunicação visual toda forma de comunicação por meio de mensagens visuais, que fazem parte de uma família de elementos que atuam sobre os nossos sentidos sonoros, térmicos e dinâmicos. Para autor, praticamente tudo que é visto é comunicação 
visual, desde uma nuvem a um cartaz. A diferença está na intenção da comunicação, que pode ser casual ou intencional.

Na comunicação visual casual, a nuvem que está no céu, não possui a intenção de nos informar que existe uma possibilidade de chover, mas acaba por advertir a quem a queira ver, podendo ser livremente interpretada por quem a recebe. Já na comunicação visual intencional é produzida com o intuito de transmitir alguma informação. Assim, a comunicação intencional, em tese, deveria ser recebida de forma com que o significado pretendido, fosse completamente absorvido.

Toda esta comunicação visual é repleta de signos, que são, num primeiro momento, percebidos pelos olhos e, depois, enviados para o cérebro, aonde serão analisados e interpretados. É só a partir daí que a imagem captada adquire algum sentido, uma vez que é apenas no cérebro que serão decifrados os signos. Para Minami (2001), a comunicação visual é elaborada no intuito de impressionar, expressar e construir. Segundo o autor, o objeto percebido impressiona a retina, provoca uma emoção e é construtivo, no sentido de ter um signo que possui a capacidade de comunicar uma informação.

Esta forma de transmissão de mensagens por meio dos sentidos tem em seu processo os três elementos básicos da comunicação: o emissor, a mensagem e o receptor.

O emissor codifica a mensagem que deseja transmitir designando um sinal. $O$ receptor recebe o sinal e o decodifica de acordo com os muitos significados que possui em seu próprio repertório. Quando o receptor decodifica o sinal e obtém exatamente a mensagem que o emissor desejou transmitir, a comunicação se realiza. (PANIZZA, 200, p. 24)

De acordo com Munari (2006) presume-se que um emissor emita mensagens e um receptor as receba. Porém, nem sempre isso ocorre, pois ambiente ao qual o receptor está imerso é cheio de perturbações que podem alterar ou anular certas mensagens. Por exemplo:

um sinal vermelho num ambiente em que seja predominante uma luz vermelha ficará quase anulado; 
ou então, uma placa de transito em cores banais, fixada junto a outras placas igualmente banais, misturar-se-á com elas, anulando-se uniformidade. $O$ índio que transmite a sua mensagem com nuvens de fumaça, pode ser perturbado por um temporal. (MUNARI, 2001, p.68)

Ainda que a mensagem visual seja projetada adequadamente, de tal modo que evite qualquer deformação durante a emissão, ao chegar ao receptor encontrará outros obstáculos: os filtros individuais. Cada receptor, de modo diferente, possui filtros, através dos quais a mensagem terá de passar para ser recebida. Estes filtros são divididos em: sensorial, voltada a capacidade perceptiva do indivíduo; funcional, baseado em suas experiências; e a cultural, com base nas crenças do receptor.

Superado os filtros individuais, a mensagem chegará enfim a zona emissora do receptor, que nada mais é do que o íntimo do receptor. Esta zona pode emitir dois tipos de resposta à mensagem recebida: uma interior e uma exterior.

Uma mensagem visual pode, por exemplo, indicar que um estabelecimento vende bolos de chocolate. Ao avistar esta mensagem visual, o observador pode ter uma resposta exterior que o mande entrar e saborear o bolo, enquanto a resposta interior o informe "não tenho fome".

Uma vez a mensagem visual recebida, segundo Munari (2001) é possível dividi-la em duas partes: a informação propriamente dita, veiculada pela mensagem e o suporte visual, definido como o conjunto de elementos que tornam visível a mensagem, como: textura, forma, estrutura, módulo, movimento.

Para Dondis (1991), embora a comunicação visual não possua um conjunto de normas e preceitos, de metodologia e nem critérios definidos, tanto para a expressão quanto para o entendimento dos métodos visual, existe a sintaxe visual, que são as linhas gerais para a criação. Assim sendo, o conteúdo das mensagens da comunicação visual também pode ser influenciado pelos elementos que a constituem: pontos, linhas, formas, tom, cores, texturas, direções, proporções, dimensões e movimentos. Desta forma, talvez não seja possível, estabelecer uma fronteira exata entre as 
duas partes que compõem a mensagem visual, pois estas estão, em geral, fortemente interconectadas, mas não é isso que torna os recursos presentes na linguagem visual incapazes de uniformizar a maneira de se comunicar, muito pelo contrário, é possível através da sintaxe visual viabilizar esse tipo de comunicação visual, sem uniformizar a mensagem.

\subsection{A COMUNICAÇÃO VISUAL NA PAISAGEM URBANA}

A comunicação visual na paisagem urbana faz parte das cidades desde 1930, quando se deu o início do movimento moderno (MENDES, 2006; MÜLLER-BROCKMANN, 1988). Ganhou força a partir de 1950, chegando ao seu ápice na contemporaneidade, quando começou a estabelecer um forte impacto na imagem das paisagens onde estava inserida (VENTURI et al., 2003).

Segundo Minami (2001) a informação é algo inerente à arquitetura. O autor cita um exemplo de um projeto anterior aos anos de 1930, o Café De Unie (Figura 5), em Roterdã, que chegou a ter em seu projeto especificado o tipo de letra estampada na fachada, em 1926. O mesmo ocorreu nos projetos de Erich Mendelsohn, para o Armazém Schoken em Estugarda em 1926 e a Casa Colombus de Berlim em 1932, onde no croqui do projeto já era possível identificar o sinal tipográfico.

Figura 5.

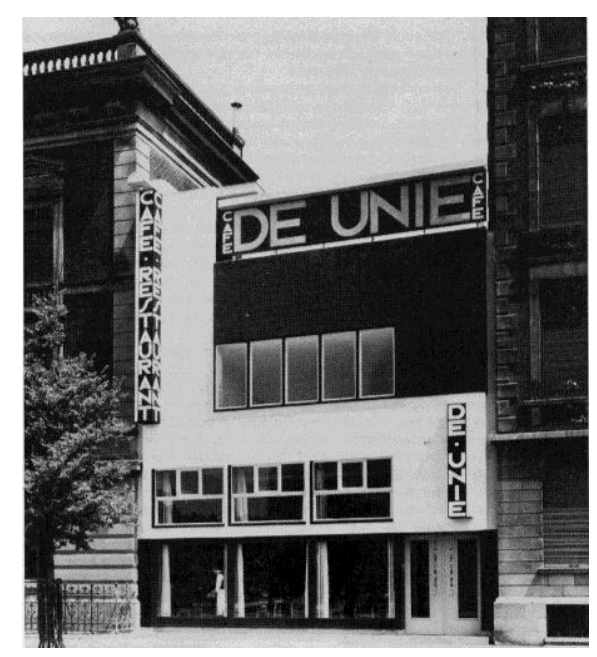


Apesar de existirem alguns formatos de comunicação visual em contextos históricos anteriores à modernidade, o surgimento da publicidade moderna, o qual inclui a mídia exterior tal como conhecemos hoje, está vinculada a um período específico do capitalismo. Com o desenvolvimento da publicidade moderna tornou-se visível o aumento significativo da presença da mídia exterior no meio urbano. Este tipo de comunicação pode ser encontrado em diferentes formatos, tais como: outdoors, placas, letreiros, front-lines, painéis eletrônicos e cartazes (MENDES, 2006).

De acordo com Mendes (2006), dentre os formatos de comunicações visuais externas há vários tipos de anúncios que podem ser classificados segundo suas funções e características em cinco categorias: identificação, cooperação, divulgação, móvel e mobiliário urbano. Dentre estes tipos as categorias de identificação, cooperação e divulgação são os que têm maior relação com a paisagem urbana.

As mídias classificadas como identificação têm a função de informar as atividades exercidas em determinado local. Os anúncios de identificação mantêm uma relação direta com o edifício sede da atividade que se quer divulgar, portanto, a construção dos suportes do anúncio deve considerar a boa visualização pelo público alvo, as características físicas do local, da fachada e do tipo de produto, entre outros. Este tipo de identificação é utilizado massivamente nas fachadas dos estabelecimentos comerciais.

As mídias de cooperação divulgam produtos ou serviços no espaço interior ou exterior do estabelecimento nos quais são comercializados, caracterizando assim uma parceria entre o fabricante e o ponto de venda. Em geral, possuem características semelhantes a mídia exterior de identificação.

Por fim, as mídias de divulgação são exclusivamente voltadas para a propaganda e não funcionam como os outros meio de comunicação (jornal, TV, radio, revista, e internet) que são concebidos em sua essência para transmitir exclusivamente uma mensagem publicitária. $O$ anúncio de divulgação tem como características principais a dimensão e a mensagem 
que deve ser apreendida em poucos segundos e, normalmente, é aliada a uma excelente localização.

Na Figura 6 é possível identificar os três tipos de mídia aplicados numa mesma fachada de um estabelecimento comercial em Fortaleza. A loja em questão se utiliza da mídia identificação, ao divulgar o nome da loja e seu segmento "Pop Club - Outlet"; da mídia de cooperação, ao expor as marcas parceiras comercializadas "Schutz, Luz da Lua, Luiza Barcelos e Arezzo"; e da mídia de divulgação ao informar ao observador da promoção que o aguarda no interior da loja através do dizeres: "Todas as marcas com descontos - até 70\%".

Figura 6. Loja Pop Club em Fortaleza traz na sua fachada 3 categorias de mídia: Existe a mídia de identificação, cooperação e divulgação. Fonte: Acervo pessoal da

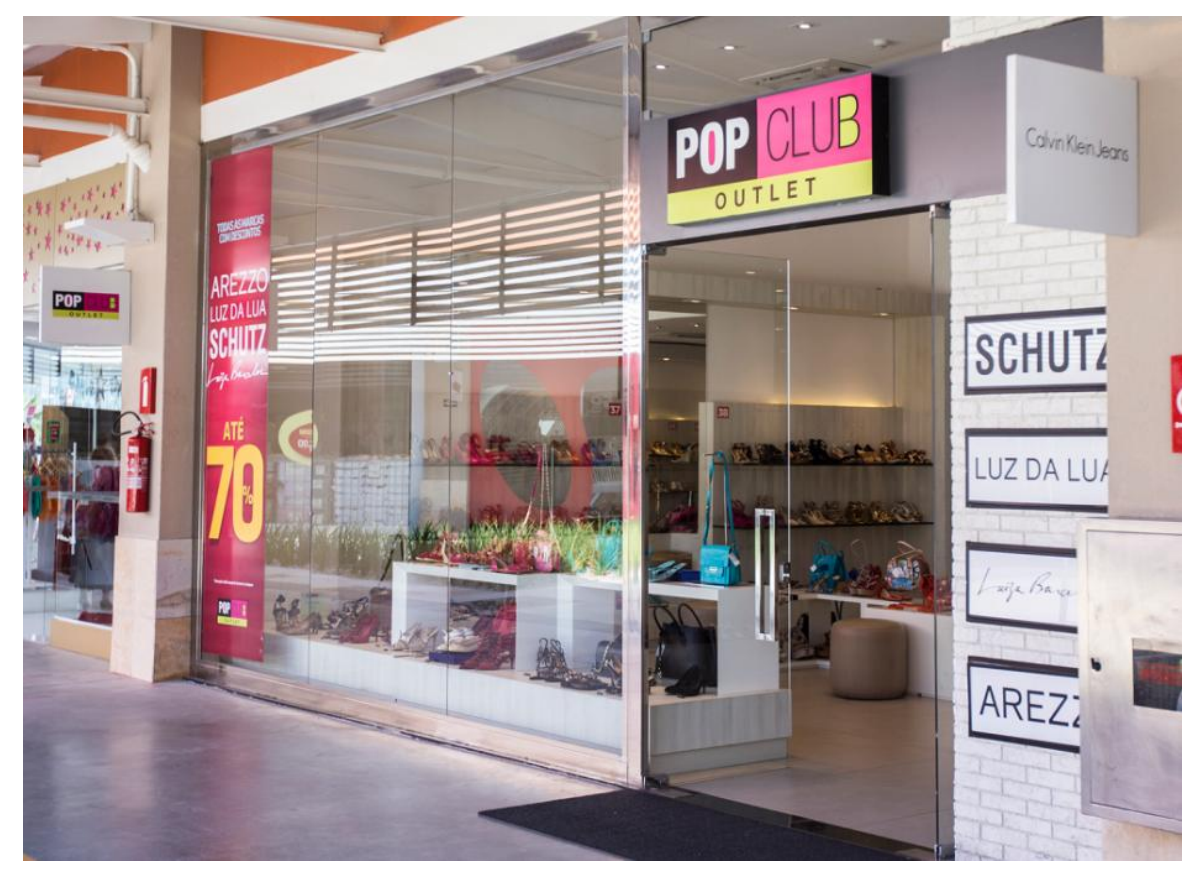

Cada vez mais, a comunicação visual externa tem se afirmado como um dos elementos estruturadores da paisagem urbana, assumindo, em certas situações, inclusive papel de marcos (LYNCH, 1999), estabelecendo até mesmo a identidade de bairros inteiros (Figura 7). Este tipo de comunicação, segundo Cury (2004):

Está presente como legítima porta-voz da informação de valores e objetos culturais, sociais, econômicos, tecnológicos e consumeristas da nossa sociedade. Interage com os outros elementos, usa-os como suportes e pode até virar ponto de referência. (CURY, 2004, p.4) 
Figura 7. A comunicação visual urbana em Times Square - Nova lorque Fonte: http://foundtheworld.com/ti mes-square-2/

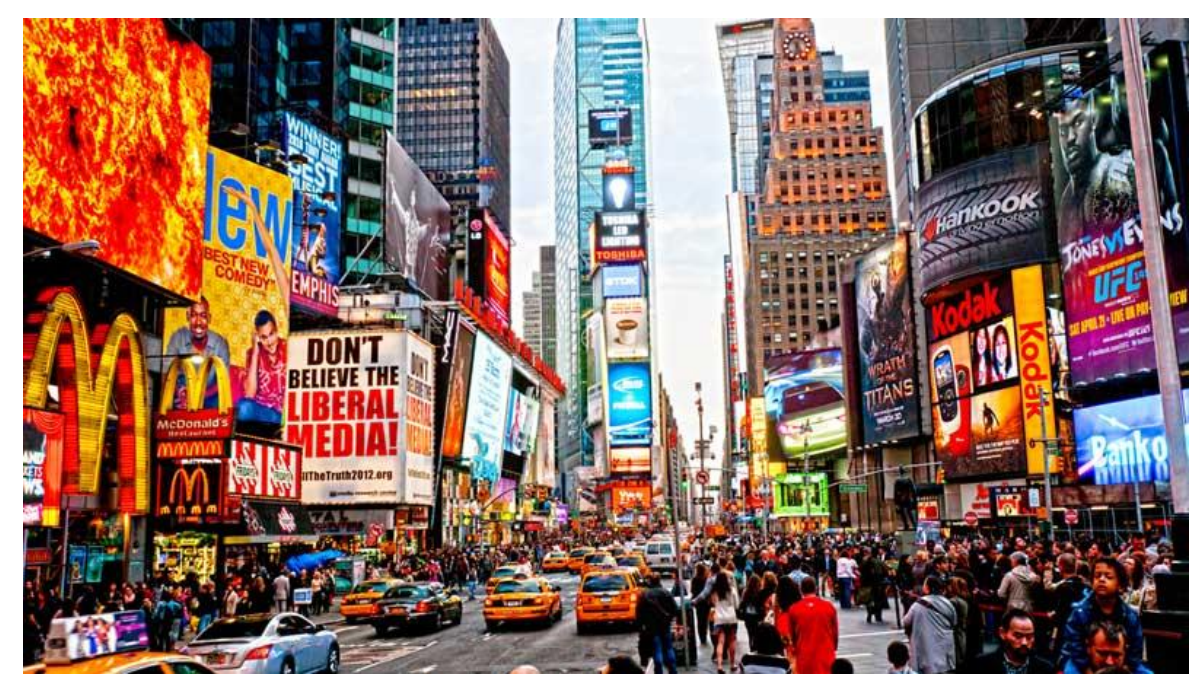

Associada à arquitetura dos edifícios, a utilização das fachadas como suporte serve, mais frequentemente, para identificação das atividades comerciais que ocorrem no âmbito da edificação, e, também, para divulgação externa, ou seja, fora do estabelecimento comercial, da marca, produto ou serviço. Minami (2001) lembra que a Comunicação Exterior faz parte do projeto do edifício, como elemento de informação. Cita como exemplos de aplicações visuais de comunicação, as agências de bancos, lojas de supermercados e redes de fast-foods.

Para Francisco Homem de Melo (1985), a comunicação visual na paisagem da cidade juntamente com a arquitetura, forma a mensagem ambiental urbana. Tal ligação entre a comunicação visual e a arquitetura mostra-se de tamanha importância, tendo sido objeto de estudo de Ohtake (1982), que fez uma análise da transformação dos marcos da cidade de São Paulo. Neste estudo sobre a evolução histórica, é possível verificar as alterações dos edifícios arquitetônicos, que passaram a ser representados por peças de comunicação exterior, como é o caso do relógio do Itaú localizado no alto do Conjunto Nacional na Avenida Paulista. Depois de 36 anos em exposição, o logotipo do banco Itaú foi removido em 2012 do topo do Conjunto Nacional, em função da Lei Cidade Limpa.

São Paulo foi uma das cidades brasileiras pioneiras em estabelecer uma lei para controle e ordenação da paisagem da capital. Em 2006, entrou em vigor a Lei 14.223, conhecida como Lei Cidade Limpa, onde foram estabelecidas as regras dos anúncios publicitários e quaisquer anúncios 
indicativos que façam parte da comunição visual de um estabelecimento. 0 objetivo da lei é coibir a poluição visual e a degradação ambiental, com o intuito de preservar a memória cultural e histórica e facilitar a visualização das características das ruas, avenidas, fachadas e elementos naturais e construídos da cidade.

Com a Lei Cidade Limpa, a colocação de anúncios indicativos nas fachadas dos imóveis ficou mais restritiva. Desde 2006, cada estabelecimento só pode ter na fachada um único anúncio indicativo com todas as informações necessárias ao público. Tal anúncio possui um tamanho máximo, que é calculado segundo a dimensão da testada do estabelecimento.

Para imóveis com testada inferior a 10 metros, a área total do anúncio com o nome do estabelecimento não poderá ser maior do que $1,5 \mathrm{~m}^{2}$ e nos casos dos imóveis cuja testada varie entre 10 metros à 100 metros, o tamanho máximo da placa será $4 \mathrm{~m}^{2}$.

Além disso, os anúncios indicativos deverão estar a uma altura mínima de 2,20 metros do chão e caso projetem-se no passeio, só poderão avançar 15 centímetros sobre este. No que diz respeito a propaganda no interior dos imóveis, a Lei estabelece que esta só não será considerada anúncio se estiver instalada a pelo menos um metro para o interior do estabelecimento.

A Lei ainda especifica para os casos dos estabelecimentos localizados nas esquinas ou com mais de uma frente para a rua, a permissão para a colocação de um anúncio indicativo em cada testada do imóvel, desde que respeitada a regra de tamanho máximo para placas de identificação.

Mesmo após a Lei em vigor, o logotipo do Itaú manteve-se fixado junto ao relógio do Conjunto Nacional por cerca de seis anos (Figura 8 e Figura 9). Isto, porque, segundo reportagem da Folha de São Paulo ${ }^{4}$, impasses com o órgão estadual do patrimônio histórico - Condephaat e com a

\footnotetext{
4 SPINELLI, Sandro. Síndica não deixa Itaú retirar marca do Conjunto Nacional. Folha de São Paulo. 23/07/2011. Disponível em: http://www1.folha.uol.com.br/cotidiano/948822-sindica-nao-deixa-itau-retirarmarca-do-conjunto-nacional.shtml
} 
administração do edifício impediam que fosse modificado o relógio sem autorização, uma vez que o Conjunto Nacional é tombado desde 2005 e o relógio é considerado um bem aderente e, portanto, também deveria ser preservado.

Figura 8. Relógio do Conjunto Nacional ainda com o logotipo do Itaú fixado em 2007

Fonte: http://noticias.r7.com/saopaulo/noticias/avenidapaulista-perde-tradicionalletreiro-do-conjuntonacional-20120105.html

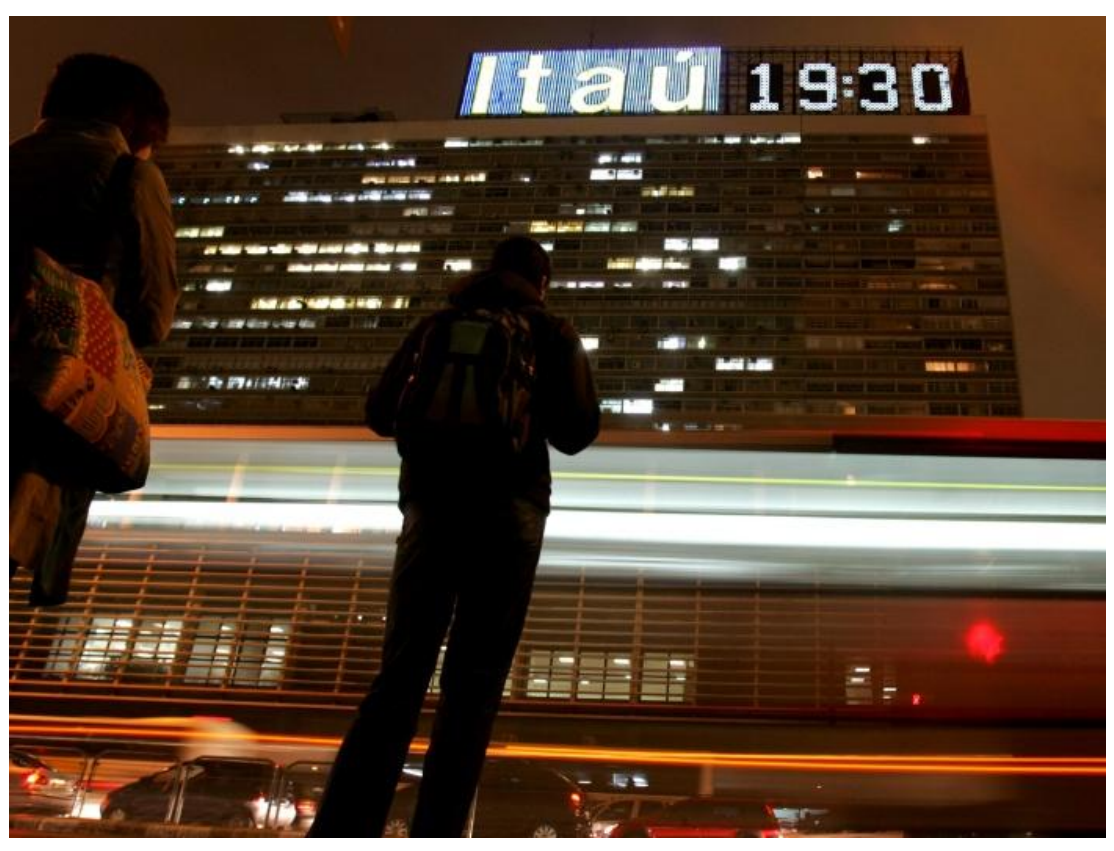

Figura 9. Relógio do Conjunto Nacional sem o logotipo do Itaú em

2013

Fonte:

http://www.panoramio.com/

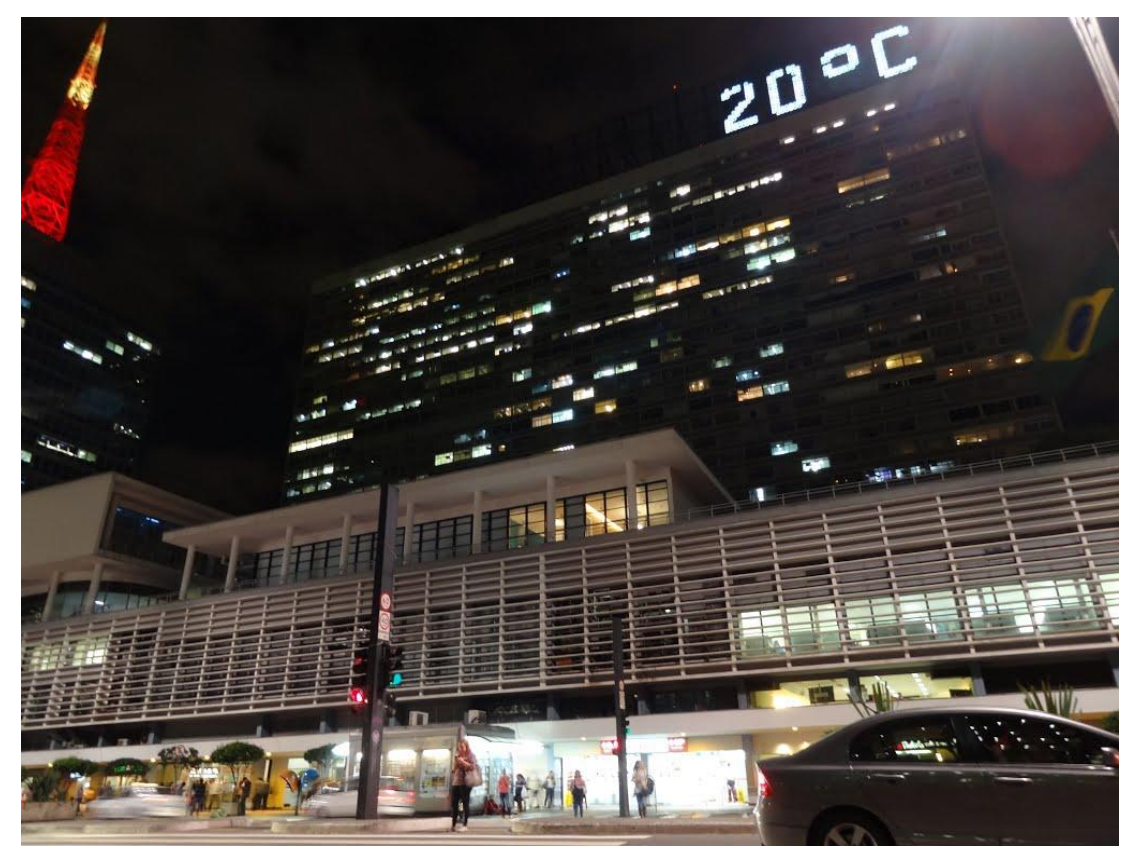
photo/90179763

A comunicação visual externa encontrou na paisagem urbana uma grande ferramenta para divulgação das empresas/marcas, atingindo de forma direta a sociedade de consumo. De acordo com Mendes (2006) a importância da paisagem urbana para a comunicação visual se deve ao fato: 
de ser um veículo pelo qual o público-alvo se expõe compulsoriamente. Em outros veículos, como televisão, jornais, revistas, rádio e internet, ao contrário, pressupõe-se a ação dos receptores para que se concretize o processo comunicativo. Além disso, a paisagem urbana é um meio de comunicação extremamente flexível, pois opera 24 horas por dia, transmite mensagens de forma instantânea e permite maior variabilidade de formatos e tamanhos para os anúncios (MENDES, 2006, p.33).

As vantagens expostas por Mendes (2006) fizeram com que a publicidade se voltasse para este poderoso canal de comunicação, o que gerou um excessivo número de anúncios publicitários em cidades que não possuíam uma legislação e/ou fiscalização eficazes. Consequentemente, problemas, como a poluição visual assolaram a paisagem urbana. $\mathrm{O}$ uso descontrolado da mídia exterior nos espaços públicos e privados das cidades, principalmente nos ambientes comerciais, atingiram de forma direta o espaço público, chegando ao ápice no começo do século XXI. Leis como a criada em São Paulo em 2006, multiplicaram-se por outras cidades do país, numa tentativa de regulamentar a comunicação visual aplicada na paisagem urbana, preservando o patrimônio paisagístico das cidades.

Iniciativas como esta são extremamente positivas para as cidades. Isso, porque, além dos benefícios para paisagem, sabe-se que a capacidade humana de processamento de informações tem um limite natural, que varia de acordo com o indivíduo e com os canais de percepção envolvidos. Em condições onde os estímulos excedam a capacidade de processamento, maior será a dificuldade de encontrar uma informação em particular, simplesmente porque o usuário terá que selecionar, identificar e reter tal informação dentre várias outras (PASSINI,1984).

Nesta concepção, Minami e Guimarães Júnior (2001) acrescentam que, os elementos que compõem a paisagem urbana precisam se organizados de forma harmônica para que a paisagem possa ser apreciada e a gerar uma sensação agradável pela população. 


\section{Capítulo 2}

\section{Comportamento do Consumidor}

Devido à complexidade envolvida na maneira como o consumidor se comporta, torna-se necessário o entendimento dos processos de decisão que moldam os padrões de compra e consumo, com o objetivo de ajudar a desenvolver uma visão geral do comportamento do consumidor, que posteriormente permitirá compreender os reflexos disso nas estratégias utilizadas pelos estabelecimentos comerciais.

O comportamento do consumidor, segundo Kotler (2000), abrange como o ser humano seleciona, compra, utiliza produtos, serviços e experiências para satisfazer as necessidades e desejos. De maneira um pouco mais ampla, Engel et al. (2000, p. 4) define como "as atividades diretamente envolvidas em obter, consumir e dispor de produtos e serviços, incluindo os processos decisórios que antecedem e sucedem estas ações".

Tais decisões são tomadas a partir do papel desempenhado pelo consumidor, seja ele o comprador - aquele que realiza a transação, o pagador - aquele que é responsável pelo pagamento do bem ou serviço adquirido, ou o usuário - aquele que usufrui daquilo que foi comprado (SHETH et al., 1999). 
Segundo Wilkie (1994) há quatro tipos básicos de decisão que o consumidor pode realizar. O primeiro deles diz respeito ao orçamento, que envolve escolhas de como gastar, quando gastar e de onde provêm os recursos. A segunda categoria se relaciona a decisão de compra, refletindo as escolhas feitas com respeito a cada tipo de produto ou serviço. Tendo o consumidor decidido sobre o produto a comprar, ele escolherá a loja de sua preferência, ou seja, onde ele irá concretizar a compra; e, por último, existem as decisões referentes à marca e ao estilo, quando se definirão com detalhes os itens que serão comprados.

Já Engel et al. (2000) reconhecem a complexidade desta tomada de decisão pelo consumidor e, desta maneira, fazem uma explicação minuciosa de cada etapa que faz parte deste processo. Para eles, o estágio inicial ocorre com o reconhecimento da necessidade, ou seja, é através de um estado de desejo que se inicia este processo de decisão de compra. Num segundo momento, depois de reconhecida a necessidade, ocorre uma busca interna na memória para determinar se seus conhecimentos sobre 0 produto/serviço a ser adquiridos são suficientes para que a escolha possa ser feita sem maiores buscas de informação. Em caso negativo, buscas externas serão exigidas. Este tipo de busca é afetado por diferenças individuais: recursos do consumidor, motivação e envolvimento, conhecimento, atitudes, personalidade, valores e estilo de vida; e influências ambientais: cultura, classe sociais, influências pessoais, família e situação.

O terceiro estágio se dá pelo processamento de informação. O usuário exposto a uma informação durante a busca externa terá um ou mais sentidos ativados e começará a partir daí um processamento preliminar. Se o conteúdo e a mensagem transmitidos forem considerados relevantes, existe uma maior probabilidade da atenção do usuário ser atraída. No estágio da atenção, os consumidores estão concentrados em um estímulo e para ele direcionam sua capacidade de processamento. De acordo com Solomon (2002), a atenção está relacionada ao grau em que a atividade de processamento é direcionada ou dedicada a um estímulo específico. Como a capacidade do cérebro dos indivíduos tem um limite para processar 
informações, estes acabam sendo muito seletivos quanto ao que dedicar sua atenção. Além das questões relacionadas à mente humana, as características do estímulo exercem um papel de grande importância na determinação do que será notado ou completamente ignorado. É neste momento em que os consumidores exercem a sua capacidade de atenção seletiva (ENGEL et al., 2000).

Após apreendida a atenção, passa-se a compreender a mensagem com base nas categorias de significado armazenadas na memória. Tendo sido feita a compreensão da mensagem, espera-se que esta seja aceita e, finalmente, armazenada na memória para que possa servir de subsídio para um próximo processo de busca de informação. A memória, por sua vez, possui três sistemas distintos de armazenamento: memória sensorial, memória de curto prazo e memória de longo prazo.

De acordo com Mowen e Minor (2004) a informação é registrada primeiramente na memória sensorial, momento em que acontece o estágio de atenção preliminar. Nesse instante, a análise do estímulo ocorre de maneira breve e inconsciente, para que se possa determinar a necessidade de se agregar uma capacidade extra de processamento ao mesmo. Caso o estímulo percebido seja entendido como algo relacionado aos objetivos do indivíduo, será direcionada a ele a capacidade cognitiva e a informação passará para a memória temporária. Nesta memória, que tem capacidade limitada, os indivíduos processam a informação ativamente. Uma de suas funções é auxiliar a transferência de informações para a memória permanente. Já na memória permanente a informação é armazenada de forma definitiva. O conhecimento de um indivíduo acerca do ambiente de consumo e a quantidade de experiência que possui sobre determinados bens fazem parte da memória permanente. O estado afetivo e o de excitação referem-se a sentimentos e emoções que os consumidores podem vivenciar e são os influenciadores das memórias temporária e permanente (MOWEN; MINOR, 2004).

Superado o estágio de processamento de informação, o consumidor passa a fazer uso de critérios de avaliação, que são fatores particulares que são 
usados no julgamento das alternativas de escolha antes de realizar a compra. Estes critérios podem envolver fatores mensuráveis e de mais fácil comparação, como segurança, confiabilidade, preço, garantia, etc., além de fatores pessoais, como o símbolo de status relacionado a uma marca, por exemplo. A complexidade envolvida com a avaliação de alternativa précompra está intimamente ligada ao processo particular de tomada de decisão de cada consumidor, que será descrita no item 2.1 deste capítulo.

Feita a avaliação preliminar do produto, o consumidor entra no estágio da compra, onde ocorre a aquisição do produto/serviço. Tais compras podem ser feitas num ponto de venda físico por intermédio, ou não, de um vendedor, ou ainda num ponto de venda online. Porém a compra, por si só, não garante o consumo. $O$ usuário pode fazer uso do que adquiriu numa primeira oportunidade conveniente ou armazenar por um curto - ou longo prazo, para uma oportunidade posterior, ou ainda abortar o processo de consumo. Esta última possibilidade tem sido cada vez mais usual nas compras pela internet, que dão direito ao consumidor desistir ou cancelar uma compra feita fora do estabelecimento comercial, com reembolso total garantido, caso haja arrependimento da transação nos 7 dias posteriores ao seu recebimento ${ }^{5}$.

Caso o usuário opte por realizar o consumo, este fará uma avaliação póscompra, que poderá resultar na sua satisfação ou insatisfação. A satisfação é a concretização de que o produto escolhido atende (ou supera) as expectativas que o consumidor levantou durante os estágios que antecederam a compra. É inegável a importância crescente da busca pela satisfação do consumidor, pois é através dela que possivelmente ocorrerá a retenção do cliente e sua lealdade perante a marca/estabelecimento. Em tempos tão competitivos, o retorno a um relacionamento mais íntimo, individual e próximo ao usuário são as chaves do sucesso empresarial.

Por fim a última etapa apontada por Engel et al. (2000) é o despojamento, onde o usuário após o consumo enfrenta as opções de descarte, reciclagem ou remarketing (revenda de itens usados). O problema relacionado ao

\footnotetext{
${ }^{5}$ Art. 49 da Lei no 8.078, de 11 de setembro de 1990.
} 
descarte do produto sempre existiu, porém com o avanço de preocupações com a sustentabilidade e o surgimento de um cliente mais responsável e ambientalmente consciente, este problema tomou grandes proporções, sendo muitas vezes um dos fatores avaliados no estágio de processamento de informação.

O organograma abaixo (Figura 10) apresentado por Engel et al. (2000) mostra uma síntese do processo decisório de compra, incluindo os diferentes estágios e os fatores que influenciam o indivíduo nesse processo.

Figura 10.

Organograma representando o modelo de processo decisório Fonte: Engel et. al., 2000.

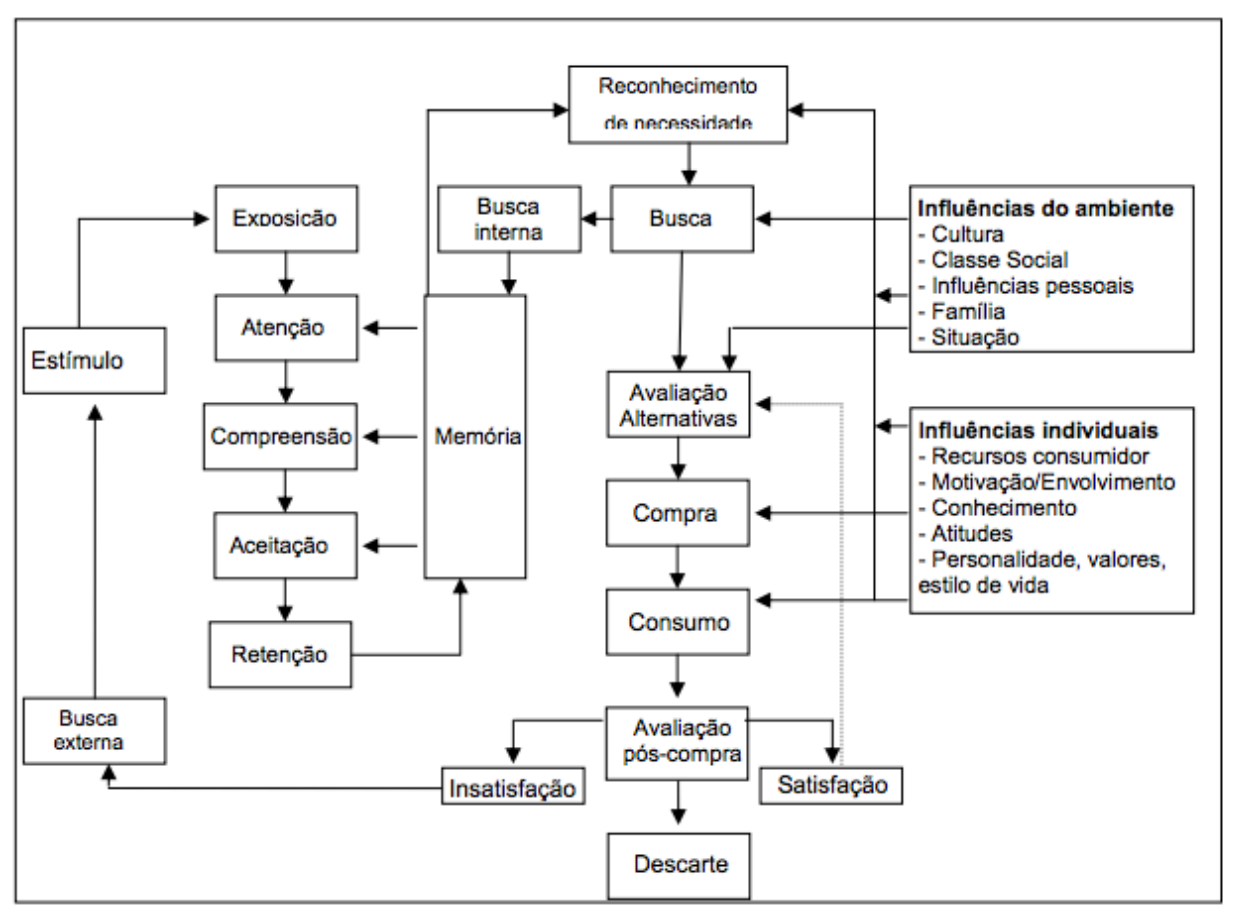

Apresentados as etapas que se dividem o processo decisório do consumidor, torna-se importante ressaltar, que não necessariamente este é um processo linear que respeita a forma e a sequência sugerida pelos autores, uma vez que os usuários podem passar por um processo complexo de decisão, mas que comumente são "processos bastante simples, em que relativamente pouco tempo e esforço são devotados à decisão" (ENGEL et al., 2000, p. 101). 


\subsection{OS PRINCIPAIS FATORES QUE INFLUENCIAM NO PROCESSO DE COMPRA}

O comportamento de compra do consumidor é influenciado por fatores culturais, sociais, pessoais e psicológicos, cujo primeiro exerce a maior e mais profunda influência (KOTLER, 2000). Engel et al. (2000) categorizam estes fatores de maneira mais abrangente, dividindo-os em: diferenças individuais, influências ambientais e processos psicológicos.

\subsubsection{DIFERENÇAS INDIVIDUAIS}

As diferenças individuais afetam o comportamento do consumidor através de diferentes modos, sendo as variáveis mais importantes, os recursos do consumidor, seu conhecimento, motivação, personalidade, valores e estilo de vida.

Os recursos do consumidor, por sua vez, dividem-se em três categorias: econômica, temporal e cognitiva. Há limites distintos entre o orçamento monetário e orçamento de tempo. Embora, o dinheiro, teoricamente, não tenha um limite de expansão, o tempo, por sua vez, possui uma restrição crítica. Como Engel et al. (2000, p. 207) exemplificam bem: "embora rendas altas possam permitir que alguns segmentos comprem mais de tudo, eles não podem compreensivelmente fazer mais de tudo". Já os recursos cognitivos representam a capacidade mental disponível para empreender atividades de processamento de informação. $O$ fato de a capacidade ser um recurso limitado tem implicações importantes na relação de como o consumidor processa informação e faz escolhas de produtos.

Lewis e Bridges (2004) estabelecem como os recursos mais preciosos da atualidade: tempo, atenção e confiança. Segundo os autores, estes recursos estão intimamente ligados, uma vez que:

A falta de tempo resulta, inevitavelmente, em períodos de atenção reduzidos. Isso, por sua vez, torna os Novos Consumidores menos dispostos a confiar. Em primeiro lugar, eles estão indispostos ou são incapazes de investir 
um pouco do seu precioso tempo para desenvolverem um relacionamento mais próximo com os fornecedores. Em segundo lugar, as pressões desse tempo muito curto os tornam menos tolerantes em relação a qualquer atraso ou erro por parte dos seus fornecedores. (LEWIS; BRIDGES, 2004, p. 42)

Já o conhecimento do consumidor consiste na informação armazenada na memória, tanto sobre características do produto em si, quanto sobre onde e quando comprar. Tal conhecimento é um fator importante, pois se sabe que as informações que o usuário possui sobre os produtos afetam substancialmente seus padrões de compra. Tornar os usuários familiarizados com uma marca há tempos já é reconhecido como um fator primordial para a construção da imagem da marca. Além disso, pode servir, como start para um conjunto de associações feitas pelo consumidor, que podem ser desde propriedades físicas e atributos da marca a benefícios e sentimentos que estão vinculados ao consumo do produto.

Porém antes que seja iniciado qualquer processo vinculado ao conhecimento, é preciso que seja despertada uma necessidade. As necessidades podem ser utilitárias, com o objetivo de se buscar um benefício funcional, ou hedônico, que abrangem respostas emocionais. Seja qualquer uma destas necessidades, o consumidor sente uma discrepância entre o estado desejado e o estado real, identificando-se desta forma o chamado estado de tensão, que impulsiona o consumidor na tentativa eliminar, ou pelo menos reduzir, esta ansiedade. Segundo Solomon (2000) é por este motivo que a motivação é um dos fatores que influenciam no comportamento do consumidor. Para o autor, é isso que faz "com que as pessoas se comportem do jeito que se comportam. Ocorre quando uma necessidade é despertada e o consumidor deseja satisfazê-la". (SOLOMON, 2000, p. 95)

Uma vez satisfeita esta necessidade, percebe-se que o estado de tensão retrocede, porém voltando a aparecer novamente num outro momento. Eis aí um dos elementos mais fundamentais de manutenção da sociedade de consumidores: a insatisfação. Se, paradoxalmente, o valor fundamental deste tipo de sociedade é a busca da felicidade, sua realização se 
transformaria, logicamente, na causa de sua extinção. É exatamente porque o consumidor não realiza sua felicidade, que o consumismo avança sobre ele como condição implacável para seu bem-estar. Muito bem explicitado por Bauman, que é claro ao afirmar:

A sociedade de consumo prospera enquanto consegue tornar perpétua a não satisfação de seus membros (e assim, em seus próprios termos, a infelicidade deles). $O$ método explícito de atingir tal efeito é depreciar $e$ desvalorizar os produtos de consumo logo depois de terem sido promovidos no universo dos desejos dos consumidores. (BAUMAN, 2008, p. 64)

Por fim, as decisões de compra variam entre os indivíduos devido às características únicas de cada um, sendo a personalidade, os valores pessoais e estilo de vida determinante na identificação desta singularidade. A personalidade é definida por Engel et al (2000, p. 283) como "respostas consistentes a estímulos ambientais". Já os valores pessoais representam as crenças do usuário sobre a vida e o sobre o que ele julga como comportamento aceitável, refletindo as escolhas que ele faz dentre uma variedade de valores sociais (ou sistema de valores) aos quais está exposto. E por último vemos o estilo de vida, que é um conceito mais popular para compreender o comportamento do consumidor, sendo definido pelos "padrões nos quais as pessoas vivem e gastam tempo e dinheiro" (ENGEL et al., 2000, p. 292). Os valores pessoais são em geral mais duradouros, enquanto os estilos de vida mudam mais rapidamente.

\subsubsection{INFLUÊNCIAS AMBIENTAIS}

É inquestionável a influência do ambiente na tomada de decisão do consumidor, sendo a cultura, a classe social, a influência pessoal e a situação, os principais fatores dentro desta categoria.

\subsubsection{Cultura}

Tradicionalmente entende-se cultura como sendo um conjunto de padrões de comportamento adquiridos socialmente e que são transmitidos aos demais membros de uma sociedade, seja através da linguagem ou fazendo uso de outro meio (MOWEN; MINOR, 2004). Contudo segundo os autores 
este conceito deve ser ampliado e de maneira mais ampla, "deve-se entender a cultura como um modo de vida"(MOWEN; MINOR, 2004, p. 294). A forma de vestir, pensar, comer e se divertir são todos componentes de nossa cultura, pois, na realidade, a cultura é fator determinante do comportamento do consumidor.

Engel et al. (2000) corroboram com esta ideia, uma vez que entendem que a cultura oferece um senso de identidade e padrão de comportamento aceitável na sociedade, sendo o vestuário, a aparência, os hábitos alimentares, a comunicação e o idioma alguns dos comportamentos mais importantes influenciados pela mesma. Para eles:

Cultura refere-se a um conjunto de valores, idéias, artefatos e outros símbolos significativos que ajudam os indivíduos a se comunicar, a interpretar e a avaliar como membros da sociedade. (ENGEL et al., 2000, p. 394)

O indivíduo aprende a cultura com o passar do tempo, pois diferentemente dos animais, os humanos não nascem com normas de comportamento. $\mathrm{A}$ cultura é passada através das gerações, principalmente por meio de instituição familiares, religiosas e escolares. É através das experiências vividas pelo indivíduo que haverá a transmissão de valores (ENGEL et al., 2000).

Porém, seria um erro entender a sociedade como totalmente unificada e estática. Dento do cenário da pós-modernidade, as sociedades possuem elementos e identidades que se articulam conjuntamente de maneira parcial, o que Engel et al. (2000) denominam de sub-cultura. Desta forma, os indivíduos são influenciados por esta sub-cultura que se refere a símbolos e valores de grupos restritos como religiosos, étnicos, geográficos.

Desta forma, Solomon (2000) entende que as opções de consumo têm que ser compreendidas considerando o contexto cultural em que são feitas, e os produtos e serviços devem sintonizar-se com as prioridades da cultura de cada época para terem mais chances de serem aceitos. As empresas que entendem as diferenças culturais e fazem estudos específicos para adaptação de estratégias diferenciadas que busquem valorizar e adequar-se 
as particularidades do consumo local, sabem o poder da sub-cultura no comportamento do consumidor.

\subsubsection{Classe Social}

O status proveniente da classe social que o consumidor se encontra (ou aspira se encontrar), frequentemente, influencia no seu comportamento. Quando escolhemos a bebida alcoólica que iremos saborear, se esta será uma cachaça popular ou um whisky raro, por exemplo, vemos como este fator social é presente.

Já se vê indicativos disso na própria definição de classe social segundo Seth et al. (2001). Conforme os autores a classe social refere-se a "posição relativa dos membros de uma sociedade, de modo que uma posição mais alta implica um status mais alto em relação às pessoas da classe social mais baixa" (SHETH et al., 2001,p. 178).

Colaborando com este conceito, Engel et al. (2000, p. 438) comenta:

Classes sociais são definidas como divisões relativamente permanentes e homogêneas numa sociedade, nas quais indivíduos ou familias partilhando valores semelhantes, estilos de vida, interesses e comportamento podem ser categorizados. Referem-se a um agrupamento de pessoas que são similares em seus comportamentos baseados em sua posição econômica no mercado.

A classe social afeta a forma como as pessoas gastam seu tempo, os produtos que compram, onde e como fazem compras. A estrutura hierárquica das classes tem extrema importância para a compreensão das preferências de consumo do consumidor, pois muitas marcas se associam fortemente à determinada classe social, de modo a influenciar o padrão de compra tanto dos indivíduos pertencentes à mesma classe, como os de outras camadas sociais. Um exemplo disso ocorre com marcas de bolsa de luxo, que são sinônimos de status para a classe mais alta e por serem produtos de desejo das demais classes, acabam sendo copiadas pelo mercado ilegal, que fornece a este público cópias falsificadas do produto.

Solomon (2002) assim como Engel et al (2000) concordam com a evidência que os produtos são percebidos de forma diferenciada, por diferentes 
culturas e classes sociais, já que o indivíduo pertencente a determinada cultura e classe social tem uma visão de mundo diferenciada dos demais, com comportamentos também diferenciados.

\subsubsection{Influência Pessoal}

O comportamento do consumidor é frequentemente afetado por indivíduos que estão ao seu redor e possuem uma estreita relação com este. A influência pessoal geralmente representa um importante papel no processo decisório de compra, principalmente quando há um grau de envolvimento. Esta influência ocorre tanto através de grupos de referência quanto através da comunicação direta, o chamado boca a boca.

Solomon (2002) apresenta três formas dos grupos de referência influenciar os consumidores. O primeiro deles é a influência informativa, que ocorre quando o consumidor busca informações sobre o produto junto a profissionais especialistas ou associações que trabalham com o produto como profissão. Esta influência tem se dizimado muito na internet através de postagens de avaliações de produtos. A segunda influência é a utilitária, onde a decisão de compra é baseada no desejo de satisfazer as pessoas com as quais o indivíduo tem interações. E por último existe a influência expressiva de valor, que ocorre quando o indivíduo compra determinado produto ou usa uma marca para associar a imagem que ele deseja ter ou aspira ser e promover a imagem que os outros possuem dele.

O grupo de referência pode ser qualquer pessoa (ou grupo delas) que influencia de forma significativa o comportamento do usuário. Normalmente o usuário procura a opinião de alguém que confia, como amigos e membros da família. Sendo o último, uma das mais impactantes influências recebida pelos indivíduos ao longo da vida(ENGEL et al., 2000).

Nos últimos anos tem ocorrido uma mudança na estrutura familiar tradicional e Solomon (2002) observa que em função destas mudanças, existe mais ênfase maior na relação com amigos e grupos de relacionamento intencionais, que se reúnem por afinidade. 
Segundo Solomon (2002) a família moderna tem dois núcleos principais. Um é a família estendida que inclui avós, tias, tios e primos e o outro é a família nuclear: mãe, pai, um ou mais filhos. $O$ autor acredita que à medida que muda o ciclo de vida familiar muda o padrão de consumo, pois as demandas e prioridades de gastos familiares com lazer, alimentação, roupas, bens duráveis e serviços mudam com o tempo. Isso, porque, de acordo com Mowen e Minor (2004), com o crescimento dos filhos, estes passam a aumentar sua influência nas decisões de compra da família. Estes jovens dividem suas discussões sobre compras com os amigos, o que demonstra que a opinião destes grupos de referência tem grande impacto sobre os adolescentes.

Para Mowen e Minor (2004) é clara a importância da família como agente de socialização, isto é, a fonte pela qual adquirimos conhecimentos e habilidades e que nos fornece condições de sermos membros de uma sociedade. A socialização do consumidor é definida como "o processo pelo qual os jovens adquirem habilidades, conhecimento e atitudes relevantes para sua atuação no mercado" (SOLOMON, 2002, p.295).

O processo de socialização do consumidor comentado acima determina as escolhas de consumo das crianças no futuro, uma vez que este processo começa ainda quando bebês, quando estes acompanham os pais em lojas. Para crianças pequenas as duas fontes primárias de socialização são a família e a mídia, quando a idade aumenta, a escola e amigos passam a serem fontes importantes deste processo.

Quando adultos, as influências podem ser despertadas no consumidor pelos chamados formadores de opinião, que são normalmente pessoas que estão em alta e possuem alguma relevância em determinado ponto. Incluem-se aqui artistas, estudiosos, personalidades, entre outros, que influem o consumo junto ao usuário, sendo motivo de aspiração. 0 consumidor os identifica como pessoas que devem ser seguidas em sua forma de pensar, agir, vestir e, com isso, passam a consumir o que estes "ídolos" consomem. Fica claro tal comportamento, quando a mídia noticia 
que as roupas usadas por Kate Middleton, duquesa de Cambridge, esgotam em poucos minutos após as primeiras fotos aparecerem na internet.

\subsubsection{Situação}

É indiscutível que o comportamento do usuário muda conforme a situação na qual o consumo do produto ocorre. Para Engel et al (2000, p. 507), a definição de influencia situacional pode ser vista como "a influência que surge de fatores que são particulares a um momento e lugar específicos, que são independentes das características do consumidor e do objeto".

As principais características que abrangem uma situação de consumo são os ambientes físicos de compra, os ambientes sociais, tempo, tarefa e estados antecedentes, que vão alem das características da pessoa e do produto. Para Mowen e Minor (2004), as influências situacionais são situações do consumidor, e, por sua vez, são fatores temporários que formam o contexto do consumo.

Propriedades do ambiente de informação, como, disponibilidade, quantidade, formato e forma de informação, podem afetar a tomada de decisão. Além de serem de extrema importância as características físicas do ambiente de loja, desde aspectos estruturais que influenciam na atividade de busca de produtos, como o layout, até elementos quase imperceptíveis, como sons, cores, cheiros e iluminação. Todos estes elementos podem influenciar o comportamento do consumidor, pois é através de técnicas do merchandising visual que se pode tornar a experiência de compra do consumidor mais agradável, assim como influenciar suas crenças e atitudes sobre a loja e a imagem da mesma.

Todas as interações sociais que ocorrem no ambiente de loja, sejam estas com outros consumidores ou com os próprios vendedores, são de grande importância na decisão de compra. A interação com outros consumidores, principalmente no que tange ao perfil do público que frequenta o ambiente, é decisiva no papel de formação da imagem da loja perante o consumidor, podendo gerar a identificação do indivíduo com a empresa ou afastamento do mesmo. Já q interação que ocorre com os vendedores é por vezes o ponto mais decisivo da compra. O grau de conhecimento do 
que está sendo vendido, a forma como ocorre o atendimento e até características pessoais dos vendedores, como simpatia ou antipatia, podem afetar decisivamente a ocorrência de uma compra ou não por parte do comprador.

Solomon (1999) acrescenta ainda um importante tipo de influência situacional no processo de compra: a questão do tempo. 0 tipo de decisão de compra que ocorre dentro da loja é moldado em parte pela maior ou menor disponibilidade de tempo para comprar. Igualmente, a percepção de tempo pode afetar fases anteriores do processo decisório, como a intensidade da busca de informações, a urgência para a avaliação de alternativas de escolha, etc. Quanto menor for o tempo disponível para compra, maior será a necessidade de um atendimento que seja percebido como rápido. Isso influencia de maneira significativa na percepção da qualidade do serviço prestado. Por isso é tão importante, que este tempo, conhecido como tempo psicológico, seja uma preocupação para ser gerenciada pelos ambientes comerciais.

O estado psicológico ou fisiológico que o consumidor apresenta na ocasião da compra é outro elemento situacional de grande relevância. O prazer e a excitação são duas dimensões que determinam se um comprador apresentará um estado emocional positivo ou negativo frente a um ambiente de consumo, isto é, se o indivíduo irá gostar ou não de uma situação e se sentirá estimulado ou não a comprar. De acordo com Donovan \& Rossiter (1982) é de acordo com os estímulos ambientais apresentados ao indivíduo, que se formam estados emocionais diferenciados que podem gerar uma resposta de aproximação ou afastamento. Em outras palavras, é o estado emocional que no caso de varejo trará a probabilidade de uma maior permanência no ambiente e consumo e a concretização ou não da compra.

Solomon (2002, p.234), afirma que "o modo como nos sentimos em um determinado momento, afeta o que temos vontade de comprar ou fazer". De acordo com o autor, o ambiente social refere-se às pessoas que acompanham os consumidores no processo de tomada de decisão de 
compra ou o presenciam. Churchill (2003) afirma que este ambiente social inclui as outras pessoas, suas características, o papel que parecem desempenhar e os modos como interagem entre si.

\subsubsection{PROCESSOS PSICOLÓGICOS}

De acordo com Engel et al (2000) são três os processos psicológicos centrais que moldam os aspectos da motivação e do comportamento do consumidor: aprendizagem, processamento de informação e mudança de atitude e comportamento.

Fator importante enquanto força propulsora e motivadora do indivíduo, a aprendizagem engloba mudanças no comportamento de um indivíduo em virtude de suas experiências. Grande parte do comportamento de um indivíduo é adquirida no decorrer de sua vida, pois segundo Kotler (2000, p. 196) quando as pessoas agem, elas aprendem. A aprendizagem envolve mudanças no comportamento de uma pessoa surgidas da experiência, que se acredita ser produzida por meio da interação de impulsos, estímulos, sinais, respostas e reforços. Um impulso é um forte estímulo interno que conduz à ação, enquanto os sinais são estímulos menores que determinam quando, onde e como uma pessoa reage.

De acordo com Schiffman e Kanuk (2000, p. 161) a aprendizagem do consumidor é definida como o processo pelo qual os indivíduos tomam consciência da compra e do consumo, sendo uma experiência que vão pôr em prática em seu comportamento futuro. Embora seja parcialmente intencional, muito da aprendizagem é acidental. Os elementos básicos que contribuem para uma compreensão da aprendizagem são a motivação, sinais, resposta e reforço.

A aprendizagem é um processo pelo qual a experiência leva a mudanças no conhecimento, atitude e/ou comportamento, por isso, qualquer pessoa que tente influenciar o consumidor está promovendo uma aprendizagem. Ela pode ser cognitiva - que se preocupa com os processos mentais que determinam a retenção da informação - ou behaviorista. Sob a perspectiva 
da abordagem cognitiva, a aprendizagem se reflete por mudanças no conhecimento, o que torna necessário entender os processos mentais que fazem com que a informação seja transferida para a memória de longo prazo. Já a abordagem behaviorista foca nos comportamentos observáveis, que ocorrem devido ao desenvolvimento de associações entre estímulos e respostas.

A retenção de informação depende do grau de repetição e de elaboração que ocorre durante o processamento de informação, que por sua vez, é afetado por muitas características individuais e de estímulo.

Influenciar as atitudes e comportamentos dos consumidores é uma das tarefas mais árduas das empresas, uma vez que a persuasão através da comunicação é uma tarefa complexa, que depende de respostas cognitivas e afetivas.

Uma atitude é algo duradouro, pois tem a tendência de persistir da mesma forma ao longo dos tempos, uma vez que o indivíduo tende a proceder e comportar-se de uma determinada forma ou estado, sendo razoavelmente coerentes e semelhantes. As atitudes estão diretamente relacionadas com a individualidade de cada consumidor e são maneiras únicas e pessoais de interagir com o meio, podendo ser alteradas, mas desde que haja necessariamente um maior esforço para isso ocorrer. Segundo Mowen e Minor (2004) uma forma de alterá-las é através do processo de condicionamento clássico que, segundo os autores permite:

(...) criar um estado motivacional que leve os consumidores a se assumirem em uma variedade de comportamentos, que inclui reagir mais positivamente à propaganda, desenvolver atitudes positivas em relação às marcas, comprar mais em restaurantes e mercearias $e$ utilizar com mais freqüência seus cartões de crédito. No condicionamento clássico, um estímulo neutro, como o nome de uma marca, é emparelhado a um estímulo que gera uma resposta. (MOWEN; MINOR, 2004, p. 92)

O condicionamento clássico foi descoberto pelo psicólogo russo Ivan Pavlov, que nos seus estudos descobriu que um estímulo que anteriormente se mostrava neutro - chamado de estímulo condicionado, 
quando emparelhado repetidamente ao estímulo de geração de resposta, denominado de estímulo incondicionado, faz com que ocorra uma transformação do estímulo neutro, fazendo com que este passe a gerar uma resposta incondicionada.

O efeito de um estímulo condicionado enquanto resposta a algo, segundo Skinner (2003) nos permite explicar o caráter das respostas aos estímulos que estão presentes, mas que são contrários ao que é visto. A visão condicionada pode se combinar com respostas a estímulos incondicionados, ou seja, podemos ver objetos familiares mais fácil e rapidamente do que objetos estranhos, devido aos emparelhamentos já gerados, que permitem estabelecer nosso repertório.

A atitude pode ser entendida como uma predisposição aprendida para se comportar de um modo coerentemente favorável ou desfavorável com relação a um dado objeto (Schiffman e Kanuk,2000). Segundo Kotler (2000, p. 196) é fazendo e aprendendo, as pessoas adquirem atitudes e crenças, que, por sua vez, influenciam no seu comportamento de compra. Uma crença é o pensamento descritivo que uma pessoa mantém a respeito de alguma coisa. As crenças podem ter como base conhecimento, opinião ou fé. Elas podem ou não conter uma carga emocional. Naturalmente, os fabricantes se interessam muito pelas crenças que as pessoas têm, pois são elas que estabelecem imagens de marca e produtos no consumidor.

Cada usuário percebe a realidade de forma diferente, tendo percepções diferenciadas sob um mesmo objeto ou produto, de acordo com três processos: atenção seletiva: estímulos selecionados e filtrados pelo indivíduo; distorção seletiva: transformação da informação em significados pessoais adaptados aos prejulgamentos individuais; e retenção seletiva: retenção de informações que satisfazem crenças e atitudes individuais.

Portanto, a percepção de um indivíduo não depende somente de estímulos físicos, mas também de estímulos propagados pelo meio ambiente ou relacionados a características pessoais. 
Estes estímulos podem ser afetivos, financeiros, sociais e até mesmo criados. Os afetivos ocorrem quando o estímulo é ocasionado por uma emoção, ou seja, o consumidor cria uma relação de afeto com o produto ou pensa no afeto da pessoa que o ganhará. Já os financeiros são causados pelo valor do produto, onde o produto possui um valor atrativo a ponto de o cliente realizar sua compra mesmo sem talvez tiver tido essa intenção. Há ainda os estímulos sociais, que surgem da necessidade de se adequar a determinado grupo social, ou seja, a necessidade de fazer parte de um grupo social faz com que 0 consumidor deseje o produto. Por último, temos os estímulos que são criados e formam no usuário uma necessidade de ter um produto, mesmo que ele não precise deste. Este tipo de estímulo normalmente é induzido pelo marketing da empresa/marca. Desta forma, o consumidor acaba sendo influenciado pelos estímulos de marketing que se tornar parte da tomada de decisão e por isso, o marketing torna-se um elo importante no processo de decisão compra.

\subsection{O PAPEL DO MARKETING NA INFLUÊNCIA DO CONSUMIDOR}

As empresas buscam fazer uso de diversas técnicas de marketing, para conseguir a atenção dos consumidores, uma vez que eles são hábeis em induzir quais estímulos que atenderão suas necessidades e expectativas. Em outras palavras, o marketing tem a habilidade de induzir o consumidor a perceber a importância da compra de um determinado produto, como forma de satisfação de suas necessidades.

O estímulo de marketing pode ser qualquer tipo de estímulo pessoal ou de comunicação, criado para influenciar o consumidor. Estes estímulos podem ser classificados como primário (ou interno), quando são provenientes do produto e seus componentes, ou secundário (ou 
externo), quando são resultantes da comunicação gerada pela propaganda.

As características do estímulo, em termos sensoriais e estruturais, e as características do indivíduo são fatores determinantes que influenciam a forma como o estímulo de marketing será percebido e interpretado pelos consumidores.

Estímulos provenientes da embalagem, do design do produto e até mesmo da própria marca são passíveis de percepção seletiva, que nada mais é do que filtros adquiridos pelo indivíduo cujos valores irão avaliar quão boa é a escolha a ser feita. Engel et al. (1970) constataram que o reconhecimento da marca de um produto reflete seletividade, pois as marcas preferidas por determinados consumidores são mais rapidamente reconhecidas do que as menos preferidas ou desconhecidas. Por isso, geralmente, os consumidores aceitam e respondem melhor às marcas que tanto Ihes parecem mais familiares quanto são eleitas como preferidas.

As estratégias de marketing para atrair o consumidor, em especial a publicidade, baseiam-se em alguns conceitos do campo da psicologia, tais como as distorções das percepções, a depreciação da fonte dissonante e a busca de apoio social. Tais estratégias têm como objetivo influenciar a percepção dos consumidores, amenizando ou modificando os efeitos da dissonância cognitiva e focando nos aspectos positivos da aquisição.

A dissonância cognitiva é uma teoria que trata das incoerências e/ou contradições existentes entre a forma como agimos e a forma como pensamos. É um conflito psicológico que o indivíduo vivencia perante uma escolha feita que não condiga com suas convicções.

Os aspectos negativos produzidos antes, durante e após o processo de consumo, dentre eles, a insatisfação, a frustração e a ansiedade, normalmente, são amenizados por meio da publicidade, que oculta os pontos negativos do produto de forma a justificar e assim, influenciar fortemente no processo decisório de compra. É o que ocorria, nas propagandas publicitárias de cigarro, onde a indústria tabagista vendia o 
produto sempre o associando a atividades esportivas ligadas ao bem-estar e, desta forma, induzia aos receptores da mensagem, que ignorassem as doenças associadas ao consumo do cigarro.

Entre as estratégias do marketing, está a de vender não só um produto, mas vender uma emoção. Segundo Norman (2008), o apelo emocional dos produtos, em muitos casos é decisivo na escolha do consumidor, uma vez que as emoções como prazer, diversão, alegria, entusiasmo, ansiedade, raiva e medo permeiam e dão sentido à experiência humana.

Existe uma estreita ligação entre consumo e emoção. Há os objetos que irão atender preceitos de usabilidade e utilidade, que são algumas necessidades importantes dos objetos, e outros que irão saciar desejos. Entende-se por este último, todos os objetos que irão mais do que apenas resolver problemas ou realizar tarefas complicadas, mas que serão uma forma de expressão, identidade, afirmação e farão parte da vida dos consumidores. A satisfação das vontades relaciona-se pouco com o aspecto racional e mais com o lado instintivo e emotivo do usuário (NORMAN, 2008).

Para que um indivíduo seja atingido emocionalmente, é possível utilizar meios simbólicos ou comportamentais. Os meio simbólicos são aqueles que irão despertar lembranças e memórias, evocando os sentimentos das pessoas. De acordo com Norman (2008) pode ser feito isso através de referências simbólicas dos objetos, onde a característica reflexiva destes remeteria as experiências pessoais por meio daquele símbolo e ao mesmo tempo serviria como sua autoimagem perante os outros indivíduos.

Devido à vida atual, repleta de estresse, ansiedade e imprevisibilidade, os indivíduos, segundo Lindstrom (2009), passaram a adotar mecanismos comportamentais ou rituais que garantam uma sensação de maior segurança, conforto e bem-estar. Este tipo de comportamento está, de certa maneira, associado aos hábitos de consumo, que superficialmente reduzem as angústias resultantes dele. 
Portanto, consumir vai além de questões utilitárias, mas há uma forte ligação com razões emocionais, psicológicas e socioculturais, que são a porta para a influência do marketing no comportamento do consumidor.

\subsection{CATEGORIAS DE COMPRA}

Como descrito anteriormente, o processo de tomada de decisão do consumidor é influenciado por fatores culturais, sociais, pessoais e psicológicos, este último decorrente de processos individuais, como motivação percepção, aprendizagem, formação de atitude e processos de tomada de decisão (ENGEL et al., 2004). A partir disso, o usuário pode se deparar com três diferentes intenções de compra, de acordo com o grau de planejamento do consumidor: a compra totalmente planejada, a compra parcialmente planejada, a compra não-planejada e a compra por impulso (ENGEL et al., 2004; MOWEN; MINOR, 2004).

A categoria totalmente planejada consiste na compra em que tanto o produto quanto a marca deste são escolhidas antecipadamente, ou seja, antes de ir ao ambiente comercial. A visita à loja torna-se então em uma mera exploração rotineira das prateleiras até encontrar o produto pensado.

Já na categoria de compra parcialmente planejada, a escolha do produto é feita antecipadamente, enquanto a marca é definida no ponto de venda. A decisão de compra pode depender de influências promocionais, preço, embalagens, display onde se encontra ou produto, alguma vantagem de compra associada, etc.

Diferente da compra planejada, na categoria de compra não-planejada, tanto o produto quanto a marca são escolhidos dentro da loja. No caso das compras não-planejadas as influências situacionais tem uma maior importância perante o consumidor. O ambiente da loja, localização geográfica, música, espaço interno, a presença de um amigo, exercem uma grande influência sobre o consumidor. 
Esse tipo de situação difere da compra por impulso, pois, na compra nãoplanejada, o consumidor já possui uma intenção de compra definida, porém não expressa ou registrada em uma lista de compras (KOLLAT; WILLET, 1967). Na compra por impulso, a necessidade de aquisição não é reconhecida antes da entrada no ambiente de loja. O consumidor vivencia um anseio repentino e poderoso de comprar algo imediatamente (ENGEL et al., 2004).

A compra por impulso é caracterizada pela tendência do consumidor a comprar espontaneamente, sem reflexão, de forma imediata, dominado pela atração emocional e absorvido pela promessa de gratificação imediata. Podem influenciar neste tipo de compra, tanto a ocasião, vitrines ou promoções no ponto de venda (SHETH et al., 2001).

Neste caso, ao realizar uma compra por impulso, onde se adquire produtos sem premeditação, o consumidor abrevia todo o processo de decisão da compra, em resposta a influências ambientais e fatores psicológicos (FABER, 1998), sem se preocupar com as consequências (ENGEL et al., 2004).

Como já dito anteriormente, comprar não é só adquirir um produto. $\mathrm{O}$ ato da compra é repleto de significados, sensações, emoções e imagens que os produtos geram nas mentes dos consumidores. Nas compras por impulso há um domínio dos aspectos emocionais, reduzindo qualquer avaliação objetiva que possa ser feita ou qualquer preocupação com as consequências que podem ocorrer devido a esta compra realizada. É um estado de desequilíbrio psicológico no qual a pessoa pode se sentir temporariamente fora de controle. O impulso para comprar um item específico é temporário e se concentra em determinado produto, num certo momento (SOLOMON, 2002), porém não resultando em consequências negativas (ROOK; HOCH, 1984).

O comportamento de compra por impulso é o que mais ocorre com os consumidores, sendo responsável pelo maior fluxo de compras. Pode ocorrer de maneira diferente, no caso da compra ser realizada em lojas físicas, por meio da Internet ou outro canal. (COSTA; LARÁN, 2003). Esta 
compra não se confunde com o consumo compulsivo, diferenciando-se pelas motivações e consequências do comportamento, e também pela frequência com que ocorrem (FABER; O'GUINN, 1988).

O consumo compulsivo é um transtorno psiquiátrico marcado pela vontade sem controle de comprar, não possuindo quaisquer critérios e consciência da sua verdadeira necessidade e/ou condição financeira. Por isso, não é considerado aqui uma categoria de compra, já que é avaliado como um problema patológico.

O comprar compulsivo é um comportamento de compra repetitivo e crônico, muitas vezes excessivo, incontrolável e estressante, que consome tempo e implica muitas vezes em dificuldades financeiras. Torna-se uma resposta primária a eventos ou sentimentos negativos, funcionando como uma válvula de escape para sentimentos de ansiedade, depressão ou tédio (SOLOMON, 2002). A compulsão torna a atividade de compra sintomática, acompanhada por um sentimento de restrição, falta de controle e, muitas vezes, de uma grande frustração e arrependimento.

Estas categorias de compra apresentadas variam substancialmente conforme o envolvimento dispensado pelo consumidor no processo de consumo e a busca de informação que ele realiza antes de concretizar a compra.

Normalmente num processo de compra de produtos de alto valor agregado, como imóveis e automóveis, há uma grande busca de informação e um alto envolvimento do usuário, o que em geral, ocorre com uma frequência menor, uma vez que estes produtos tendem a ser comprados esporadicamente. Em geral, este tipo de compra, faz parte da categoria totalmente planejada, exatamente por se caracterizar como extremamente racional, onde a busca e processamento da informação são fatores de grande peso para a decisão de compra.

De maneira geral, o nível de envolvimento depende da natureza do produto. Aqueles que possuem um alto valor simbólico tendem a exigir um alto envolvimento, pois, frequentemente estão agregados a este tipo de 
produto uma representação ao consumidor de status social e estilo de vida. Já produtos habituais de consumo, como os de conveniência, tendem a despertar menor envolvimento dos mesmos. Assim, o grau de envolvimento dispensado por cada consumidor é reflexo da importância que o mesmo agrega ao produto, tal qual a maneira com que o mesmo lida com suas preferências de consumo gerando diferentes graus de envolvimento para cada indivíduo.

Os produtos mais habituais, que possuem uma grande variedade e diferença entre as marcas, por não apresentarem maiores riscos no processo de escolha do consumidor, possuem, geralmente, um baixo envolvimento, com um nível de informação mediana, principalmente para efeitos de comparação das marcas no momento da compra. É o que ocorre nas compras parcialmente planejadas, onde os usuários não são fiéis às marcas por não perceber um alto valor agregado ao produto.

A fidelidade às marcas faz com que o consumidor não busque informações sobre os produtos por ter experiência e/ou ter desenvolvido a preferência, e até mesmo o hábito, por determinado produto de determinada marca. Ocorrem situações onde a marca se torna tão importante na hora da decisão de compra, que independente do produto que ela lance, esta já possui alta aceitação por parte do consumidor. É o que acontece, por exemplo, com os produtos da Apple, onde o produto não é tão importante, quanto o estilo de vida e o status que a marca vende. Os produtos da Apple não são simples tablets e smartphones, são produtos de desejo com um valor intangível agregado e por isso não são denominamos iguais às outras marcas, possuem nomes próprios: Ipads e Iphones.

Há ainda situações onde consumidores não possuem desejo de investir tempo no processo de tomada de decisão e por hábito acabam sendo leais a uma determinada marcar. É o que normamente ocorre com as compras de produtos de limpeza em geral.

Os tipos de compra acabam por ter íntima relação com os tipos de bens de consumo. Segundo Kotler (2006) a grande variedade de bens de consumo existente em nossa sociedade pode ser classificada em termos de hábitos 
de compra em quatro categorias diferentes: bens de conveniência, de compra comparada, de especialidade e não procurados.

Os bens de conveniência são aqueles comprados com alta frequência, e que demandam também um mínimo esforço para serem adquiridos. São produtos geralmente com preço menor e que tem por estratégia de promoção atingir a massa, ou seja, um público bem heterogêneo. Por isso, a distribuição destes produtos deve ser ampla, atingindo assim uma grande quantidade de clientes.

Os produtos de compra comparada são comprados após certo esforço por parte dos usuários, que buscam comparar características do produto em questão em termos de adequação, qualidade e preço e modelo. Um dos motivos para os clientes realizarem esta comparação é devido um maior impacto negativo que uma compra errada deste tipo de produto pode acarretar. Normalmente os produtos de compra comparada possuem preços um pouco mais altos que os de conveniência. A estratégia de promoção continua sendo de atingir a massa, mas agora com um foco mais específico, e a distribuição passa a ser mais seletiva, pois agora o volume vendido é bastante inferior, tendo então de ser mais direcionado para seu público-alvo. Os bens de compra comparados podem ser divididos ainda em bens de compra homogêneos, que são semelhantes em qualidade, mas têm diferenças significativas no preço, e bens de compra heterogêneos, que diferem em certos aspectos do produto e serviços cuja importância pode ser maior que a do preço. É devido à compra comparada que temos, nas grandes cidades, a existência de ruas especializadas, feiras e Shopping Centers especializados, onde você consegue encontrar uma grande variedade de marcas de um mesmo produto (VARGAS, 2001).

A terceira categoria é dos bens de especialidade, que são produtos com características singulares ou possuem uma identificação de marca pelos quais os compradores estão dispostos a fazer um maior esforço para obtêlos. Este tipo de produto não aceita comparações, os consumidores investem tempo e energia para chegar aos revendedores que dispõem dos produtos que eles desejam, uma vez que a distribuição é exclusiva e possui 
pontos de venda específicos para a classe do produto. Um carro importado é um bom exemplo desse tipo de produto.

Por último, estão os bens não procurados que são produtos que os consumidores normalmente não desejam comprar, ou produtos os quais estes consumidores não conhecem. Para que estes produtos sejam vendidos, é necessária que seja criado nos usuários a necessidade do valor destes produtos. São exemplos deste tipo de produtos, seguros de vida e jazigos.

Na Tabela 1 abaixo apresenta uma síntese comparativa das categorias de bens de consumo apresentado por Kerin et al. (2007):

Tabela 1. Quadro comparativo dos diferentes tipos de bens de consumo

\begin{tabular}{|c|c|c|c|c|}
\hline \multirow[b]{2}{*}{$\begin{array}{l}\text { BASE DE } \\
\text { COMPARAÇĀO }\end{array}$} & \multicolumn{4}{|c|}{ TIPO DE BEM DE CONSUMO } \\
\hline & CONVENIÊNCIA & $\begin{array}{l}\text { COMPRA } \\
\text { COMPARADA }\end{array}$ & ESPECIALIDADE & NĀO-PROCURADO \\
\hline Produto & $\begin{array}{l}\text { Pastas de dentes, } \\
\text { mistura para bolos, } \\
\text { sabonete, sabão em } \\
\text { pó }\end{array}$ & $\begin{array}{l}\text { Câmeras,TVs, malas, } \\
\text { roupas }\end{array}$ & $\begin{array}{l}\text { Carros Rolls Royce, } \\
\text { relogios Rolex }\end{array}$ & $\begin{array}{l}\text { Plano funeral, } \\
\text { dicionário }\end{array}$ \\
\hline Preço & $\begin{array}{l}\text { Relativamente } \\
\text { barato }\end{array}$ & Relativamente caro & $\begin{array}{l}\text { Geralmente muito } \\
\text { caro }\end{array}$ & Varia \\
\hline Local (distribuição) & $\begin{array}{l}\text { Pulverizada; muitos } \\
\text { varejistas }\end{array}$ & $\begin{array}{l}\text { Grande número de } \\
\text { varejistas selecionados }\end{array}$ & Muito limitado & Geralmente limitado \\
\hline Promoção & $\begin{array}{l}\text { Preço, disponibilidade } \\
\text { e ênfase no } \\
\text { conhecimento da } \\
\text { marca }\end{array}$ & $\begin{array}{l}\text { Enfase na } \\
\text { diferenciaçäo dos } \\
\text { concorrentes }\end{array}$ & $\begin{array}{l}\text { Exclusividade da } \\
\text { marca e ênfase do } \\
\text { status }\end{array}$ & $\begin{array}{l}\text { Conhecimento da } \\
\text { marca é essecial }\end{array}$ \\
\hline $\begin{array}{l}\text { Fidelidade à marca } \\
\text { por parte dos } \\
\text { consumidores }\end{array}$ & $\begin{array}{l}\text { Consciente da marca, } \\
\text { mas aceita substitutos }\end{array}$ & $\begin{array}{l}\text { Prefere marcas } \\
\text { especificas, mas } \\
\text { aceita substitutos }\end{array}$ & $\begin{array}{l}\text { Muito fiel à marca; } \\
\text { aceita substitutos }\end{array}$ & Aceita substitutos \\
\hline $\begin{array}{l}\text { Comportamento de } \\
\text { compra dos } \\
\text { consumidores }\end{array}$ & $\begin{array}{l}\text { Compras frequentes; } \\
\text { pequeno esforço e } \\
\text { pouco tempo } \\
\text { comprando }\end{array}$ & $\begin{array}{l}\text { Compras pouco } \\
\text { freqüentes; necessita } \\
\text { de muito tempo de } \\
\text { comparação para } \\
\text { compra }\end{array}$ & $\begin{array}{l}\text { Compra pouco frequiente; } \\
\text { necessita de tempo } \\
\text { muito maior e ampla } \\
\text { pesquisa para compra }\end{array}$ & $\begin{array}{l}\text { Compra muito pouco } \\
\text { freqüente; necessitando } \\
\text { de alguma comparaçäo } \\
\text { para compra }\end{array}$ \\
\hline
\end{tabular}

Fonte: Kerin et al., 2007, p.257

Independente do tipo de compra a ser realizada pelo consumidor sabe-se que o processo de escolha não se encerra antes da compra ser concretizada, pois diversas influências situacionais dentro do ambiente de loja podem, definitivamente, afetar a decisão de compra do consumidor. 
Segundo Mowen e Minor (2004) os efeitos situacionais são estabelecidos por elementos circunstanciais que formam o contexto no qual a atividade de compra ocorrerá em um determinado local e momento. Wells e Prensky (1996) apontam uma série de aspectos de natureza situacional que podem influir no comportamento de compra do indivíduo. Segundo os autores, fazem parte destes aspectos: características físicas, como layout, iluminação, música, propaganda, expositores, etc.; condições facilitadoras, como cartão de crédito, entrega rápida; interações sociais, e o humor do consumidor. Por isso, a importância em se investir num merchandising visual aplicado de maneira consciente ao ambiente comercial, pois desta maneira a chance da compra se concretizar torna-se muito maior.

\subsection{O SUJEITO PÓS-MODERNO E O CONSUMO: OS REFLEXOS DA SOCIEDADE PÓS-MODERNA NO MODO DE CONSUMIR}

Desde a Revolução Industrial ocorrida na Inglaterra no século XVIII, quando pode se considerar o marco para o início do reconhecimento do sujeito como consumidor, muitas mudanças sociais ocorreram, sendo uma das mais relevantes, a ascensão e centralidade dos processos de consumo. Esta questão é de fundamental importância para se entender as relações sociais do mundo atual, "o cimento que liga os sistemas sociais, suas instituições e as experiências cotidianas dos indivíduos" (ABERCROMBIE, 1994, p. 58).

O sujeito pós-moderno tem-se pautado pelo quase desapego às tradições, apesar de mesmo na mais moderna das sociedades a tradição ainda desempenhar um papel, este é muito menos significativo. No lugar disso, as relações do capitalismo, orientadas pela lógica do mercado, acabam assumindo um papel central na atualidade (SLATER, 2002). Na realidade, segundo Jameson (1997), o que ocorre não é um desapego às tradições, mas a apropriação da cultura à lógica capitalista, ou seja, esta acaba sendo assimilada como mercadoria. Isso ocorre, devido a lógica da pósmodernidade, onde o capitalismo se constitui como uma das dimensões 
institucionais mais relevantes da atualidade e sua influência sobre o indivíduo, através dos processos de percepção da experiência mercantilizada, é cada vez mais ampla (GIDDENS, 2002).

Giddens acredita que caso haja um consenso em praticamente todos os autores da atualidade que discorrem sobre o indivíduo desta sociedade, é a definição deste como um indivíduo que "experimenta sentimentos de impotência em relação a um universo social cada vez mais amplo e alheio" (GIDDENS, 2002, p. 178). Desta forma, é possível concluir que quanto mais extensos e diversificados os sistemas sociais, mais o indivíduo será privado de qualquer possibilidade de autonomia.

Outra característica importante da pós-modernidade são as inúmeras mudanças tecnológicas, que influenciam no modo de vida do sujeito pósmoderno. Galindo (2008, p.32) afirma que "os consumidores estão mudando, a mídia está mudando, a sociedade está mudando, as empresas estão mudando, as tecnologias estão em constantes mudanças, logicamente com os processos comunicativos [...] não seria diferente".

Desta forma, a publicidade, propaganda e marketing, que são os responsáveis pela propagação e veiculação de uma marca/empresa, promovem a determinação de públicos-alvo com a identificação de padrões de consumo e segmentação por estilo de vida, sendo fundamentais para alimentar o ciclo capitalista. A propaganda transforma-se em um poderoso mecanismo de atribuição de significado às mercadorias, fazendo com que qualquer produto desenvolvido possa adquirir qualquer significação, que sugira o valor desejado a este (MCCRACKEN, 1989). Um grande exemplo disso são empresas, como a Diletto ${ }^{6}$ (Figura 11), que para conquistar o

\footnotetext{
${ }^{6}$ A fabricante de sorvetes paulistana Diletto, fundada em 2008, recebeu um belo impulso de uma história única. A inspiração para criar os picolés veio do avô do fundador da empresa, o italiano Vittorio Scabin, que segundo marketing da empresa foi sorveteiro da região do Vêneto. Seu retrato e a foto do carro que usava para vender sorvete apareciam nas embalagens da Diletto e ajudaram a construir a autenticidade da empresa: "La felicità è un gelato". No entanto trata-se apenas de um personagem criado pela agência de publicidade para agregar valor à marca. (EXAME, 22/10/2014.)
} 
mercado e criar um vínculo afetuoso com o consumidor, se preocupam cada vez mais em contar histórias que as diferenciem das concorrentes, mesmo que estas histórias sejam inverídicas.

Figura 11.

Imagens do avô e do carro (que teria sido usado para vender sorvete na Itália) que

apareciam nas embalagens da Diletto

Fonte:

http://www.gelatodi

letto.com/nossa-

historia
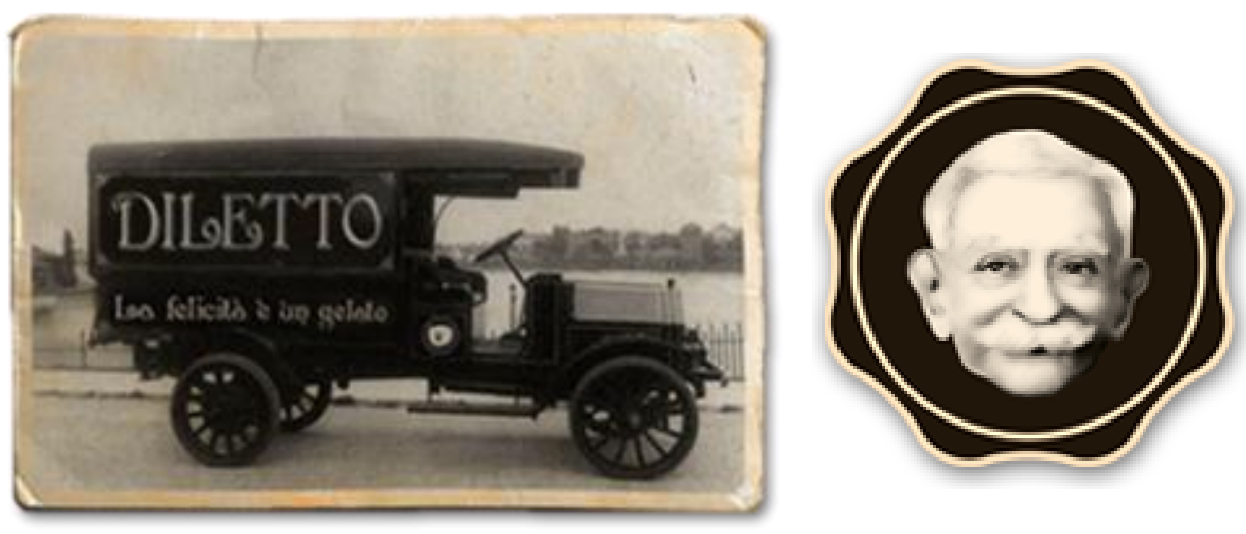

Dentro desta cultura de consumo é possível identificar diversas microculturas, também denominadas de comunidades de marca, comunidades de consumo ou tribos de consumo. Estas subcategorias delimitam o caráter fragmentado da cultura do consumo na atualidade e são orientados basicamente por padrões distintos de compra e compartilhamento de significados, práticas e valores sociais (THOMPSON; TROESTER, 2002).

Um exemplo de uma marca que busca se apropriar da realidade da microcultura é a Red Bull. Muito mais que uma marca de uma bebida energética, o Red Bull tem se direcionado a promover esportes focados em pessoas que buscam adrenalina, atingindo a um grande espectro de esportes radicais, promovendo inclusive competições, como a Flugtag (Figura 12), onde os participantes se propõem a dar asas aos mais variados objetos. Com isso, a marca se apropria de uma microcultura e ao mesmo tempo reforça seu conceito de liberdade, tão retratado pelo seu tagline ${ }^{7}$ : "Red Bull te dá asas".

\footnotetext{
${ }^{7}$ Tagline é uma frase que retrata a essência da marca, fazendo parte da sua existência, diferente do slogan que é criado para uma campanha, um produto novo ou um público específico e normalmente tem prazo de validade.
} 
Figura 12. Competição Flugtag promovida pela Red bull Fonte:

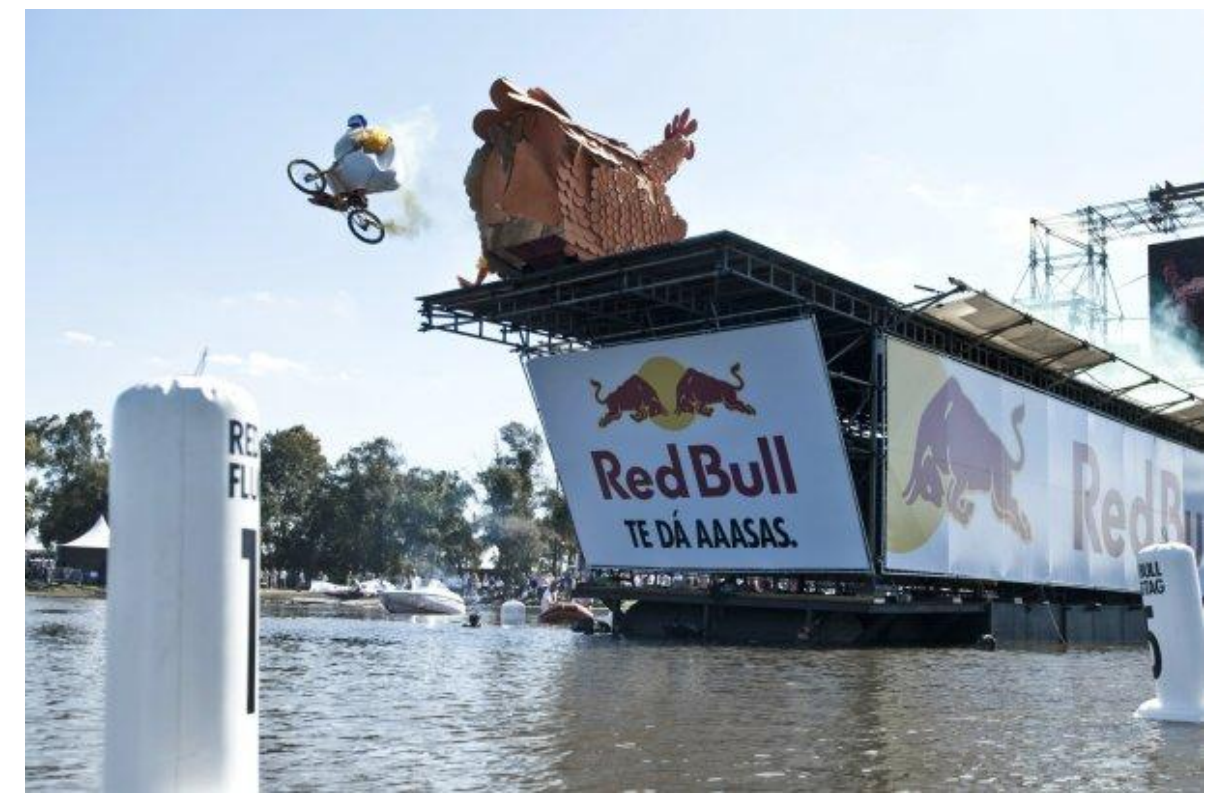

A Red Bull é um perfeito exemplo de marca que entrega algo democrático e universal, a adrenalina, e sabe evoluir muito bem para microculturas, através de esportes com pessoas de interesses comuns, atingindo diretamente este público específico.

A microcultura refere-se a uma rede de significados, estilos, visuais e práticas de modo de vida que segundo Thorton (1997) são expressões exclusivas de um determinado tipo de classe socioeconômica e ambiente social. Entretanto a realidade atual demonstra que a microcultura no âmbito do consumo se revela como um fenômeno social que não se limita a uma esfera socioeconômica particular, pelo contrário, permeia simultaneamente diversas posições e ambientes sociais, através de interesses comuns, compartilhados pelos indivíduos que a integram. Isso se deve ao fato do sujeito, antes entendido como possuidor de uma identidade unificada e estável, ser um sujeito fragmentado, composto não de apenas uma identidade fixa essencial ou permanente, mas um sujeito que assume várias identidades diferentes em diferentes contextos e por vezes até mesmo contraditórias. Segundo Hall (2001, p. 13) “à medida que os sistemas de significação se multiplicam somos confrontados por uma multiplicidade desconcertante e cambiante de identidades possíveis".

Este é um dos desdobramentos da pós-modernidade - a "crise das identidades". Hall (2001) caracteriza tal crise como a fragmentação e 
deslocamento cultural, as quais alcançam as dimensões das "paisagens culturais de classe, gênero, sexualidade, etnia, raça e nacionalidade" (HALL, 2001, p.9) e desdobram-se em nossas identidades pessoais, "abalando a idéia que temos de nós próprios como sujeitos integrados".

O que identificamos como cenário da pós-modernidade são sociedades que não são totalmente unificadas, porém seus elementos e identidades se articulam conjuntamente de maneira parcial, onde a estrutura da identidade permanece aberta. Se, por um lado, o quadro é perturbador por retirar a segurança e estabilidade que existia na modernidade, por outro é positivo, pois a inconstância e mobilidade abrem possibilidades para novas articulações e produção de novos sujeitos (HALL, 2001).

Se considerarmos o pensamento de Deleuze e Guattari (2010, p. 44), que afirmam que "eu não sou determinado no tempo, a não ser como Eu passivo e fenomenal, sempre afectável, modificável, variável", talvez seja possível conjeturar essa crise de identidade como apenas uma forma de exprimir a condição humana, antes limitada e reprimida por estatutos sociais e agora, de certa forma, permitida diante da possibilidade de se encontrar em seu estado puro de fluidez.

Esta crise das identidades que o usuário passa a viver durante a pósmodernidade impacta a forma de consumir e, consequentemente, na maneira como são planejados os espaços comerciais.

As marcas passam a entender que é uma necessidade atual que não seja estagnada a função de uma edificação. $E$ mais do que isso, veem a necessidade de que a arquitetura se renove enquanto função. Bógea (2009) é muito claro ao explicar que:

A arquitetura, em consonância com o caráter nômade da modernidade, criou novos conceitos, que já não a vinculam exclusivamente às construções monolíticas, projetadas para usos específicos. Erguem-se edifícios capazes de absorver o efêmero. Uma arquitetura mais do tempo que do espaço. (BÓGEA, 2009, pg. 7)

Um bom exemplo disso é loja American Girl Place em Nova lorque (Figura 13), onde você tem múltiplos serviços, que atendem a múltiplas 
identidades, dentro de um mesmo sistema. Além disso, a marca ultrapassa a barreira da lógica serializada e padronizada, permitindo ao consumidor a individualização de cada produto, indo além de uma simples customização, focando na verdadeira singularidade (Figura 14).

Figura 13.

Fachada da loja American Girl

Place em Nova lorque

Fonte: Acervo pessoal da

autora.

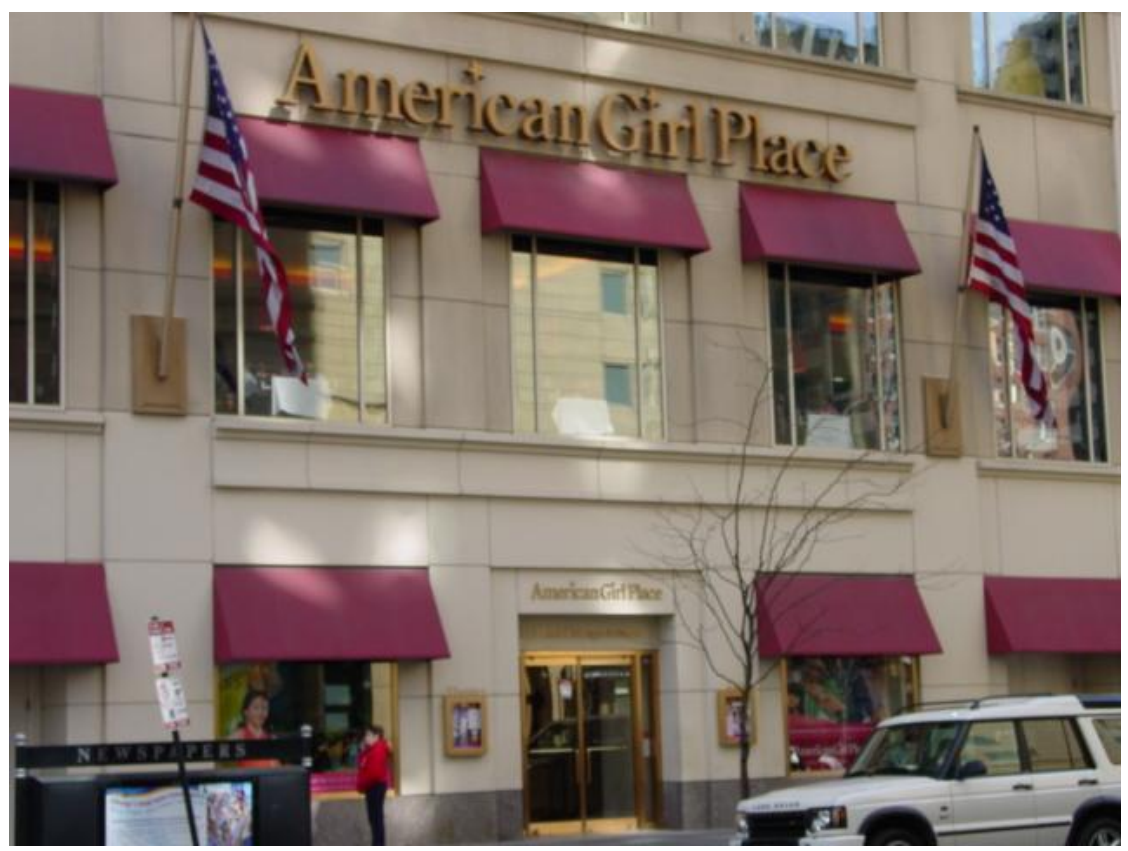

Figura 14.

Bonecas vendidas na American Girl Place que permitem a individualização por parte do

consumidor

Fonte:

http://www.americangirl.com/

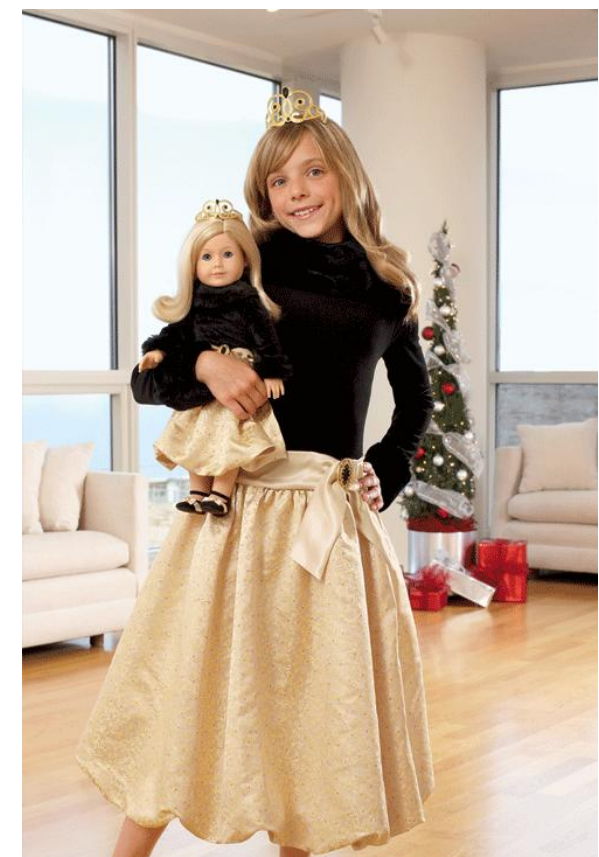

O indivíduo na pós-modernidade possui uma multiplicidade de identidades possíveis e segundo Sodré, seu poder de transformação quase que instantânea denotam uma espécie de modulação existencial em que o 
indivíduo torna-se vulnerável "à irradiação viral dos signos, e as identidades podem ser produzidas como um bem de mercado" (SODRÉ, 1996, p. 179).

A forma como este usuário mantém seu senso de identidade através do tempo e se define nas relações com outras pessoas está intimamente ligado com as interações do consumidor com os produtos e marcas. Tal fato é vivenciado pelos consumidores no momento que estes resolvem consumir produtos que consideram importantes para reforçar seu senso de identidade dentro da sua tribo de consumo (AHUVIA, 2005). Lipovetsky afirma que "jamais se consome um objeto por ele mesmo ou por seu valor de uso, mas em razão de seu 'valor de troca signo', isto é, em razão do prestígio, do status, da posição social que confere" (LIPOVETSKY, 1989, p. 171). Isso extrapola o próprio limite do produto, tornando os consumidores leais aos símbolos e imagens associadas à marca.

A dinâmica do consumo altera drasticamente a inserção social do sujeito, onde este acaba sendo valorizado por aquilo que ele possui, e não por aquilo que é. Segundo Benson (2000) a filosofia que sintetiza o atual momento é "compro, logo existo", uma vez que o ato de consumir é mais impactante do que sua aparente simplicidade. De forma objetiva o autor é claro ao afirmar que "não é acerca de comprar, é acerca de ser", pois entende que o ritual de consumo é uma experiência que vai além do simples ato de comprar, tendo raízes profundas nas dimensões humanas do sujeito, principalmente no que se refere a construção da sua identidade.

Há uma grande disparidade entre a ansiedade do indivíduo por uma coerência na construção da sua identidade e uma falta de suporte sociocultural para este fim, em função de uma ausência considerável da comunidade e da tradição compartilhada. $\mathrm{O}$ indivíduo experimenta estas ausências e é provocado a se inserir em um processo mutável de experimentação de estilos de vida, na busca pela identificação daquele que irá Ihe trazer o preenchimento ao vazio em questão.

Fato é que vivemos em uma sociedade de consumo na qual seus membros são moldados à revelia, com a obrigação de desempenhar o papel de consumidores. De acordo com Bauman (1999) para que isso ocorra, os 
indivíduos não podem de maneira alguma ter os estímulos ao consumo interrompidos, precisam estar sempre alertas e expostos a novas mercadorias e valores simbólicos, para que se mantenham num estado de excitação contínua, prontos a terem seus desejos renovados pela próxima novidade do mercado.

Baudrillard (1972), afirma que o consumo não reflete uma necessidade natural de mudança, mas atua como mecanismo de sanção psicológica para inquietações de outra ordem, social e de prestígio. Ou seja, segundo ele:

À medida que se sobe na escala social, os objetos multiplicam-se, diversificam-se, renovam-se. Muito rapidamente, aliás, e sob o signo da moda, a sua circulação acelerada acaba por significar e fazer ver uma mobilidade social que não existe realmente. É já este sentido de certos mecanismos de substituição: muda-se o carro porque se não pode mudar o apartamento. É ainda mais claro que a renovação acelerada dos objetos compensa muitas vezes a frustração de uma aspiração ao progresso social e cultural. (BAUDRILLARD, 1972, p. 39)

Neste sentido é de suma importância para o entendimento das dimensões psicológicas e sociais de consumo, a centralidade dos valores que atribuímos às coisas. Para Rokeach (1973), valores são crenças que não podem ser provadas por um senso convencional, elas são "ideais abstratos" que representam o que o indivíduo entende como "concepção do desejável" (ROKEACH, 1973, p. 10, apud D’ANGELO, 2004).

Segundo estudos realizados por Ahuvia, apesar de uma vasta quantidade de mercadorias serem consumidas através desta lógica descartável e substituível, o indivíduo elege alguns poucos objetos com os quais estabelece uma relação de amor. Por fim, o sujeito utiliza estes objetos para solucionar os conflitos e tensões provenientes da construção do seu 'eu', na busca de uma identidade que não seja contraditória e momentânea, numa tentativa de corromper a realidade. Para Giddens (2002), trata-se de uma eterna luta do eu contra as imposições do mercado. Fato é que o mercado publicitário não estimula e muito menos valoriza esta realidade, pois ela não é interessante para eles, uma vez que o caráter descartável das mercadorias é o responsável por gerar o anseio pela 
próxima novidade, movimentando o ciclo de produção, que gerará o lucro do modelo capitalista.

As atividades da publicidade, propaganda e marketing vendem a lógica de que a capacidade de acesso aos bens de consumo é praticamente igualitária, numa tentativa de omitir o hiato, cada vez maior, entre os excluídos e os incluídos, ou como classificaria Baumam (1999), entre os seduzidos e os reprimidos.

Quanto maior for a "procura do consumidor", gerada obviamente pela eficácia cada vez maior de sedução do mercado, mais segura e próspera será a sociedade de consumidores, tornando ainda mais ampla a separação entre os que desejam e os que podem satisfazer os seus desejos. (BAUMAN, 1999, p. 164)

Da mesma forma Debord (2003) teoriza a respeito do poder do ritual de consumo na sociedade pós-moderna, acreditando que a nossa sociedade alimenta-se e é alimentada pela anulação crescente do ser humano diante de um mundo tão cheio de coisas, imagens e pessoas. Segundo ele nos alimentamos do fácil, do descartável, daquilo que nos engessa, ao invés de nos fazer refletir e libertar. Sua teoria entende que este cenário é proveniente do sintoma da pressa, da falta de tempo, da aceleração em que se converteram os nossos dias atropelados e insanos. Este é o primeiro sintoma da dominação sobre a vida social que se degrada, transformando os valores de "ser" em "ter", que acaba resultando numa busca de posse e aparência.

O processo de absorção por parte dos indivíduos de um conjunto de símbolos e códigos torna-os peças estratégicas, onde se busca conseguir maximizar ganhos, num mercado simbólico e efetivo de trocas, não mais apenas entre bens, mas, agora, essencialmente entre pessoas transfiguradas na forma de mercadorias (BAUMAN, 1999). Produz-se aí uma relação cíclica paradoxal onde, ao consumir, o indivíduo se torna, ele próprio objeto de consumo, tendo em vista que a apropriação de bens se estrutura por uma lógica de preparação e habilitação dos "sujeitos" para os mais diversos tipos de mercado. 
O consumidor acaba sofrendo um processo de objetificação, sendo gravada na sua mente a ideia de que para 'ser' é preciso 'ter'. Tal consumidor tornase um escravo consumista pós-moderno, que enaltece a marca ao invés do 'sujeito'. (TAVARES, 2004)

A publicidade, aliada ao consumo vem como forma de concretizar o que se deseja ter e ser através de estratégias e apelos emocionais, empregados com o objetivo de criar a ideia de que o público será recompensado com sensações positivas, satisfação do ego e/ou projeção social.

Neste contexto, o consumismo leva a uma sobrevivência ampliada, gerando também 'pseudonecessidades' para garantir esse processo de expansão da produção e do consumo. As necessidades individuais de autoafirmação ou perfeição pessoal são todas traduzidas na necessidade de consumir e possuir. Como dito anteriormente, esse desejo faz parte da aparência de valor de uso de tais bens, e não do próprio valor de uso, e como tal é extremamente superficial, levando apenas ao alívio momentâneo dos desejos frente à frustração duradoura das necessidades (por isso a necessidade de ser produzir 'pseudonecessidades').

Eis aí um dos elementos mais fundamentais de manutenção da sociedade de consumidores: a insatisfação. 0 mercado se nutre da infelicidade que gera, induzindo o comportamento do consumidor indispensável à sua continuidade (BAUMAN, 1989, p. 189). Se, paradoxalmente, o valor fundamental da sociedade pós-moderna é a busca da felicidade, sua realização se transformaria, logicamente, na causa de sua extinção. É exatamente porque o consumidor não alcança sua felicidade, que o consumismo avança sobre ele como condição implacável para seu bemestar. Bauman (1989) é categórico ao afirmar que:

A sociedade de consumo prospera enquanto consegue tornar perpétua a não satisfação de seus membros (e assim, em seus próprios termos, a infelicidade deles). $O$ método explícito de atingir tal efeito é depreciar $e$ desvalorizar os produtos de consumo logo depois de terem sido promovidos no universo dos desejos dos consumidores. (BAUMAN, 1989, p. 64) 
Segundo Campbell (2001) esta valorização aparentemente paradoxal da insatisfação teria derivado da transição de valor: o que Bauman vê como busca da satisfação, na realidade trata-se da buscar do prazer. A satisfação implica o encontro ou reencontro de certo equilíbrio, na adequação daquilo que foi consumido com aquilo que foi desejado. Já o prazer é uma qualidade de experiência, ele é instantâneo e transitório. O consumo desempenha-se muito bem com esta forma de sensibilidade: cada produto é uma promessa de prazer multiplicado a cada aquisição e, posterior, decepção.

O consumo como processo de significação deixa de ser voltado "para o outro" e passa a ser orientado "para si", em favor de um valor experiencial, no qual a relação com o objeto é agora o elemento determinante na motivação das práticas consumistas. Tal mudança envolve a retomada da centralidade do valor de uso dos bens como elemento predominante no interior destas práticas. Segundo Lipovetsky:

Das coisas, esperamos menos que nos classifiquem em relação aos outros e mais que nos permitam ser mais independentes e mais móveis, sentir sensações, viver experiências, melhorar nossa qualidade de vida, conservar juventude e saúde. Naturalmente as satisfações sociais diferenciais permanecem, mas quase já não são mais que uma motivação entre muitas outras, em um conjunto dominado pela busca das felicidades privadas. (LIPOVETSKY, 2007, p. 42)

Este novo cenário tem criado consumidores mais interessados em experiências emocionais e que the tragam bem-estar. É um consumidor cada vez mais informado, infiel, reflexivo e estético (LIPOVETSKY, 2007).

Gade (1998) afirma que esta postura do sujeito pós-moderno em busca do prazer é útil para a sociedade do consumo, pois desta forma o usuário procura maximizar seu prazer e minimizar seu sofrimento, buscando consumir bens e serviços que Ihe proporcionem uma maior sensação de bem-estar.

No raciocínio de Campbell, o consumismo atual está pautado numa realidade onde a sensibilidade e a imaginação predominam sobre a razão. 
Através do consumo busca-se satisfazer necessidades simbólicas e oferecer a experimentação dos prazeres criados pela imaginação. Segundo as próprias palavras do autor:

O consumidor moderno desejará um romance em vez de um produto habitual porque isso o habilita a acreditar que sua aquisição, e seu uso, podem proporcionar experiências que ele, até então, não encontrou na realidade. (CAMPBELL, 2001, p. 130).

O consumo de experiência serve como um apoio aos anseios do usuário. Só uma simples contemplação de vitrines já se torna um bom exercício de se entregar às compras, sem necessariamente consumir, funcionando assim, como uma representação de experiência mental e prazerosa aos sujeitos da nossa sociedade.

Tal forma de consumo chega ao seu ápice, quando os motivos de compra passam a ser movidos exclusivamente pelo status. Neste momento, compra-se outra coisa: "a experiência da marca". E essa é a grande novidade do consumo atual, muito ligado à perfeição criada pelo anúncio e o consumo do simbólico. Este tipo de consumo é extremamente explorado pelas marcas de luxo, que oferecem experiências que despertam nos consumidores o desejo de continuar vivenciando isso (LIPOVETSKY; ROUX, 2005).

Autores como Lindstrom (2007) afirmam que a sociedade pós-moderna é ideal para o uso da experiência da marca como ferramenta de comunicação, pois segundo o autor "no mundo atual, não são as mensagens em alto volume que tem maior chance de serem ouvidas. $O$ que aumenta a chance de atingir os objetivos é uma mensagem que apela aos diversos sentidos". O pesquisador mostra que atualmente, as marcas devem deixar de lado o dogma da comunicação bidimensional, baseada apenas em som e imagem e passar para uma comunicação que explore todos os sentidos humanos.

Quanto maior o número de estímulos sensoriais envolvidos na construção de uma marca, maior será o número de memórias sensoriais e mais forte será a adesão do consumidor a esta marca. Este apelo multissensorial 
melhora a percepção de qualidade do produto, gerando ainda mais valor a marca (LINDSTROM, 2007).

Enquanto as mídias tradicionalmente consolidadas vêm perdendo investimentos, os pontos de venda, em geral, registram alta valorização financeira (BLESSA, 2010). São vários os motivos para o ocorrido, mas a autora ressalta que o principal deles é a dificuldade em acessar os novos consumidores, que são conscientes e possuem conhecimento sobre o valor do seu tempo e do seu dinheiro, além de serem mais seletivos quanto aos meios de comunicação.

Desta forma, a ambientação da loja se torna fundamental para estimular e interferir na percepção do consumidor, determinando seu tempo gasto e apresso pelo espaço, influenciando diretamente no seu comportamento de compra.

\subsection{O PERFIL DOS NOVOS CONSUMIDORES}

O perfil do consumidor vem se alterando ao longo dos anos, de forma mais rápida e impactante. Segundo Ventura (2010) até 2030, as empresas irão se defrontar com estas mudanças, o que de fato tem ocorrido ao longo desta última década.

Fatores relacionados a questões estruturais, como envelhecimento populacional, a valorização da qualidade de vida, o consumo precoce, o aumento do poder de consumo das classes de baixa renda e do poder de decisão de crianças e adolescentes estão sendo responsáveis pelo ingresso de novos consumidores que, se mostram cada vez mais exigentes e responsáveis do ponto de vista socioambiental.

Essa variedade de transformações no comportamento do consumidor brasileiro implica em nove perspectivas de consumo, conforme classificado por Ventura (2010) em consumo exigente, consumo +60 , consumo 
saudável, consumo responsável, consumo de baixa renda, consumo precoce, consumo online, consumo prático e consumo em nichos.

\subsubsection{CONSUMO EXIGENTE}

Cada vez os consumidores estão com uma maior exigência de produtos e serviços de qualidade e isso inclui a valorização crescente da certificação e rastreabilidade. Selos de certificação, como os fornecidos pelo Inmetro e Procel, e de garantia, como os certificados ISO 9001, tem se tornado requisitos indispensáveis para aqueles que anseiam solucionar as crescentes preocupações do consumidor com a qualidade.

A importância da certificação em alguns ramos de negócio se tornou tão grande, que visando a saúde e segurança do usuário, o governo brasileiro tornou compulsório a certificação em alguns casos. Berços e carrinhos infantis, chupetas e artigos escolares são alguns dos produtos que obedecem tal regulamentação. Desde 2005, por exemplo, todo brinquedo comercializado no Brasil utilizado por crianças de até 14 anos, necessita de uma certificação, independente do produto ser nacional ou importado. A certificação de brinquedos visa evitar possíveis riscos que, mesmo não identificados pelo público, podem surgir no uso normal ou por consequência de uso indevido do brinquedo.

Tais certificações tem acumulado um aumento significativo ao longo dos anos, conforme é possível verificar no Gráfico 1:

Gráfico 1.

Número acumulado de brinquedos certificados pelo Inmetro (bilhões) Fonte: Elaborado pelo autor com base nos dados do Inmetro http://www.inmetro.gov.br/

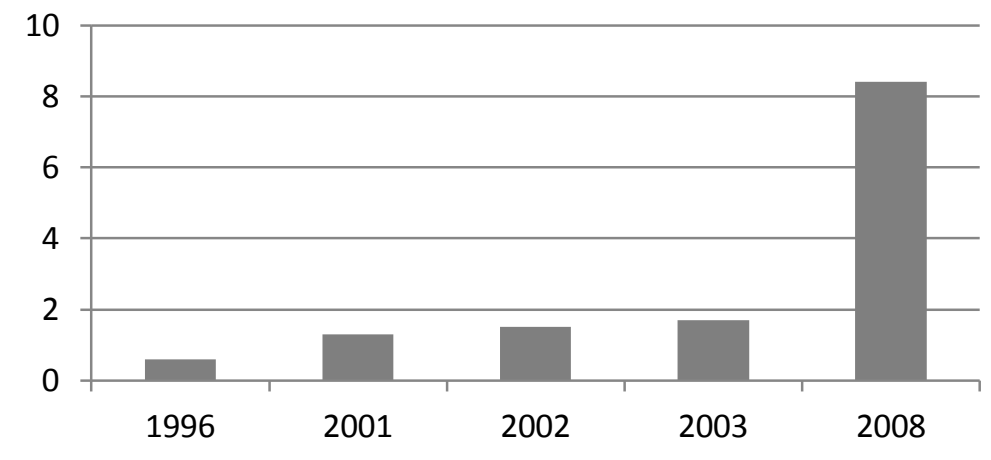

Diante deste consumidor cada vez mais exigente, a rastreabilidade de produtos e processos produtivos é outro fator que tem possuído valor 
crescente. Isto permite não somente adequar os produtos às normas de qualidade e aos requisitos de aparência, funcionalidade e facilidade de manutenção exigidos pelo consumidor, como garantirá também o acesso à informação da história, percurso e processos pelos quais o produto passou desde sua origem até a chegada a casa do consumidor.

Uma marca que já entendeu a importância disso e tem investido em campanhas publicitárias que divulgam sua preocupação com o monitoramento de todo o processo que envolve seu produto, é a Friboi. Além de ter como slogan "Carne confiável tem nome: Friboi", a empresa investe em campanhas (Figura 15) que demonstram toda sua preocupação com a cadeia produtiva, reforçando este pensamento através de frases de impacto como "confiança do início ao fim":

Figura 15. Campanha da Friboi veiculada em jornal impresso Fonte:

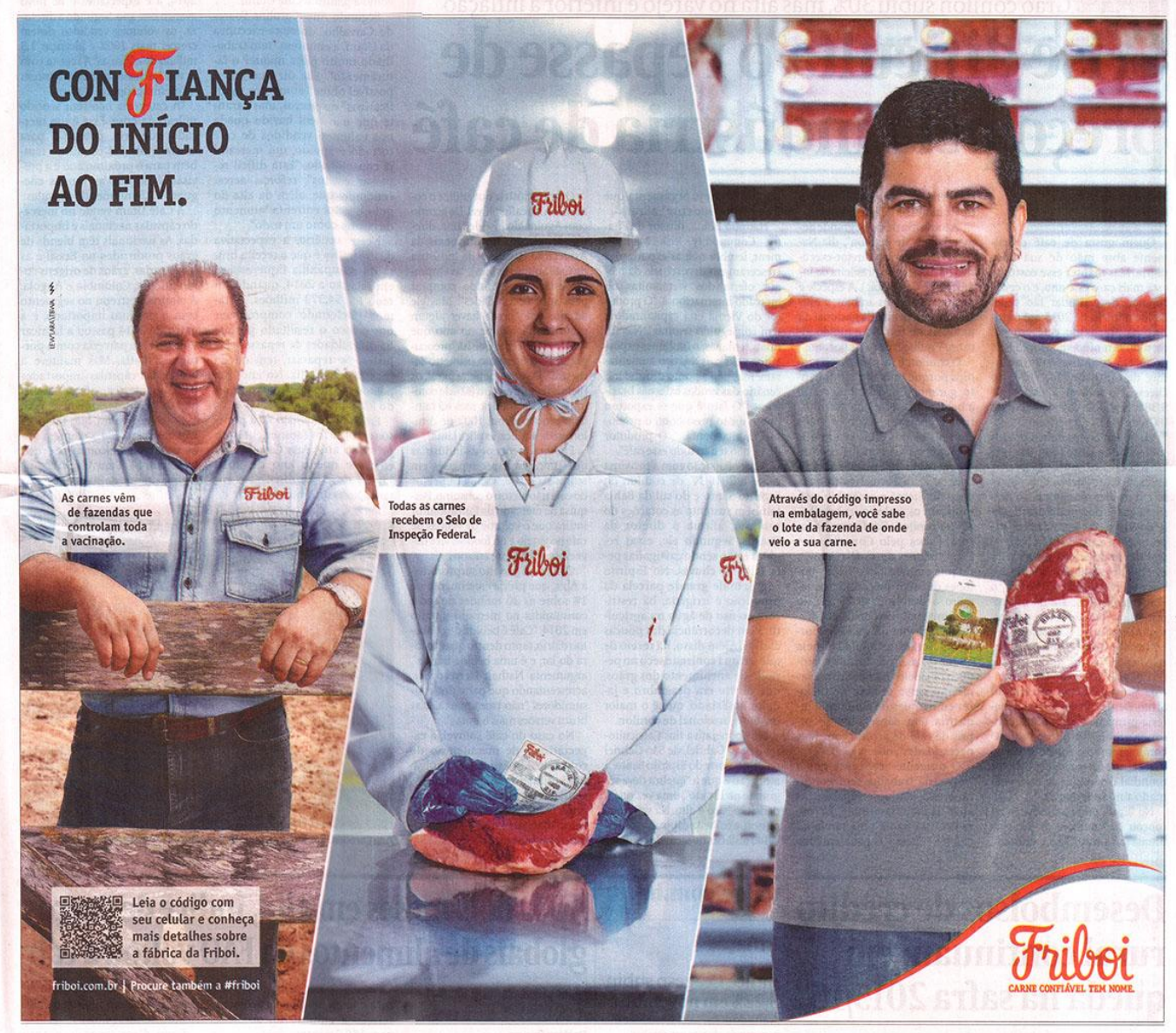




\subsubsection{CONSUMO +60}

O aumento da demanda por produtos e serviços orientados ao consumidor com mais de 60 anos, em virtude do envelhecimento populacional, é uma realidade do panorama brasileiro. As estatísticas do Censo 2000, do IBGE, apontam um aumento de $17,8 \%$ no número de brasileiros com mais de 60 anos, em relação ao Censo de 1991. Em 2000, o Brasil tinha 14,6 milhões de idosos e a expectativa do IBGE é que em 2020 o grupo de idosos chegue a quase 30 milhões. E este número deve continuar crescendo, conforme é possível verificar no Gráfico 2:

\section{Gráfico 2.}

Projeção de

crescimento

da População

Brasileira com

mais de 60

anos

Fonte:

Elaborado

pelo autor

com base nos

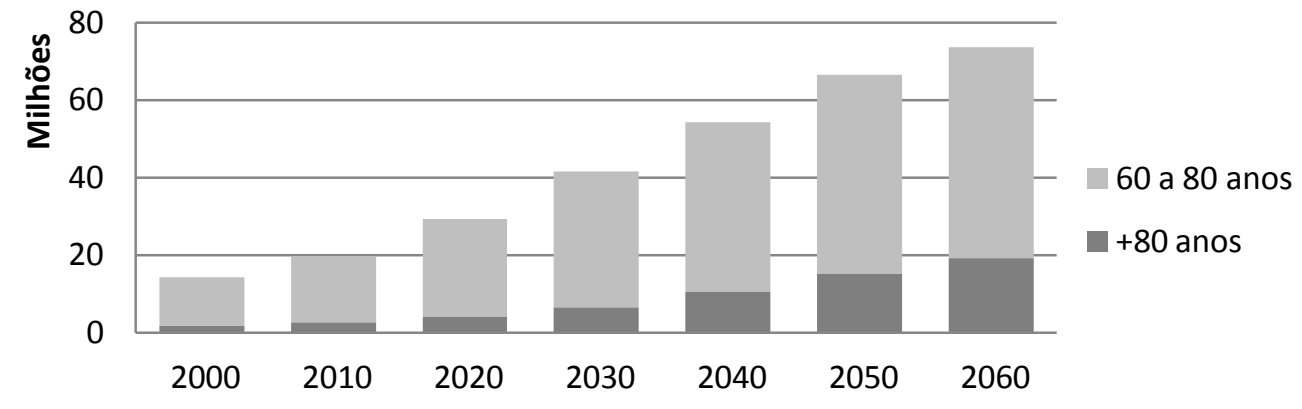

Este crescimento não foi apenas em números absolutos, mas também percentualmente sobre o total da população brasileira, saltando de 7,3\% em 1991 para 8,6\% em 2000, chegando a 9,7\% em 2004, atingindo 11,1 \% em 2008.

Por trás deste movimento encontra-se o expressivo aumento da longevidade da população brasileira. Em apenas 34 anos (1980-2014), a expectativa de vida ao nascer aumentou em cerca de treze anos. A média de vida passou de 62,6 anos em 1980 para 75,2 em 2014.

Progressivamente ao aumento de idosos no Brasil, há um aumento significativo da renda mensal dessa faixa etária. E de acordo com Ventura (2010), estima-se que o rendimento dos idosos, que em 2006 era de 16 bilhões de reais, alcançara 25 bilhões de reais em 2020 . 


\subsubsection{CONSUMO SAUDÁVEL}

A valorização da saúde nas decisões de consumo e aumento da demanda por produtos e serviços orientados a uma vida saudável é a terceira tendência de consumo brasileiro, apontada por Ventura (2000).

A preocupação em ter e manter uma vida saudável tem se mostrado uma forte influência na maneira de consumir do brasileiro, principalmente no que tange a alimentação, onde produtos taxados como saudáveis ganham cada vez mais espaço nas prateleiras dos supermercados.

O segmento de alimentos orgânicos, por exemplo, cresceu 25\% em 2015 e neste ano deve aumentar $35 \%$. Nos últimos dois anos, o número de produtores aumentou de maneira impressionante, em 2013 eram 6.719 produtores orgânicos, hoje são $80 \%$ a mais, alcançando 12.136 .

Sem contar, o surgimento de lojas especializadas em tais produtos (Figura 16), que tem servido como ponte entre os produtores e o consumidor final.

Figura 16. Mercado São Jorge Loja especializada em produtos orgânicos de

Florianópolis/SC

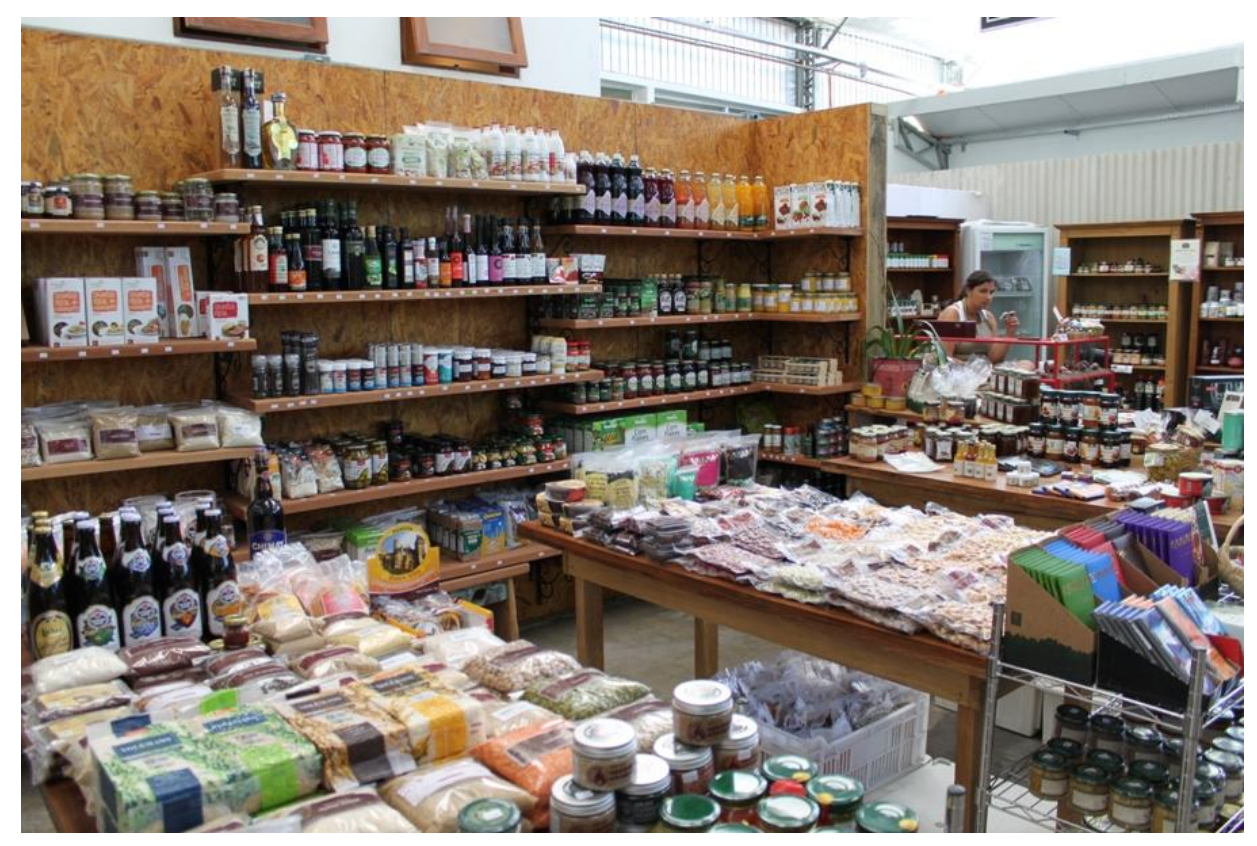

Juntamente com este espírito de consumo saudável, tem seguido a mesma tendência de crescimento, a quantidade de academias e clínicas de estética instaladas. De 2007 a 2010, o número de academias dobrou no Brasil. Hoje, segundo IHRSA Global Report 2015 (International Health, Racquet \& Sportsclub Association), aproximadamente 15 milhões de latino-americanos 
são membros de uma academia, sendo que só o Brasil possui mais da metade das academias na América Latina. O país possui cerca de 31.800 academias, sendo o segundo no ranking de maior número de academias por habitante.

\subsubsection{CONSUMO RESPONSÁVEL}

A expressão consumo responsável é um termo utilizado para incluir a preocupação com aspectos sociais, além dos ecológicos, nas atividades que envolvam a aquisição de produtos/serviços. O consumidor responsável possui um compromisso ético, uma consciência e responsabilidade quanto aos impactos sociais e ambientais que suas escolhas e comportamento de consumo podem acarretar (MMA et al., 2005).

Tem ocorrido um aumento da conscientização socioambiental do consumidor brasileiro, onde produtos que possuem esta preocupação sustentável tem sido cada vez mais valorizados. Segundo pesquisas realizadas pelo Monitor de responsabilidade social corporativa 2009 (apud VOLTOLINI, 2010) 9\% dos consumidores consideram a análise sobre o comportamento socioambiental da empresa fabricante como fator decisivo de compra, ficando atrás de fatores como confiança na marca (16\%), características funcionais (19\%) e o preço (35\%), sendo este último o quesito mais importante para o consumidor brasileiro no momento da escolha do produto.

Além disso, a intensificação das exigências éticas e de eficiência no processo produtivo, com a criação de leis de regulação ambiental, tem colaborado para que se torne mais concreto a conscientização do consumidor.

Nesse contexto, muitos consumidores tem buscado obter cada vez mais informações sobre os produtos oferecidos, desde a aquisição de matériasprimas, passando pelo processo de fabricação, até o destino final.

Questões relacionadas a fase que antecedem a colocação do produto no mercado, principalmente no que tange a fase de testes está cada vez mais 
em voga. A utilização de animais como cobaias para testes de produtos é cada vez mais discutida. Para a indústria de cosméticos, por exemplo, tais testes foram proibidos recentemente em toda a União Europeia. Já no Brasil, eles ainda são permitidos e apesar da existência de selos internacionais (Figura 17) que certificam que nem o produto final nem nenhum ingrediente usado para fabricar o mesmo foram testados em animais, no Brasil a informação não é obrigatória e vai da decisão da empresa informá-las ou não.

Figura 17.

Três tipos de selos encontrados nas embalagens:
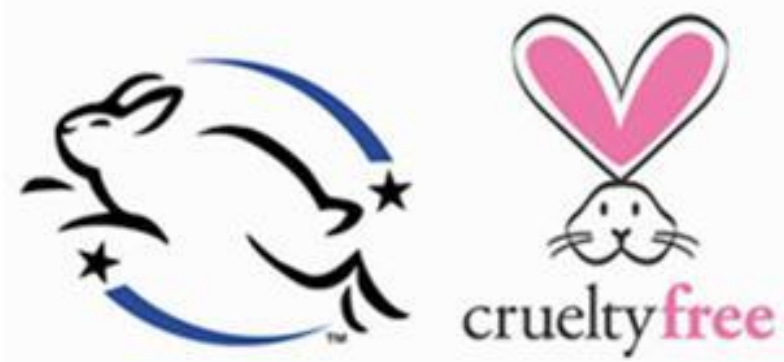

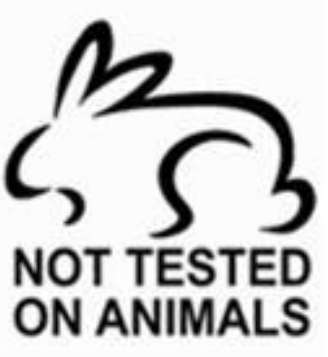

De acordo com Ventura (2010), o consumidor busca cada vez mais conhecer a composição, as condições de processamento e transporte e os fabricantes dos componentes do produto. Para isso, ele acredita que:

(...) serão cada vez mais demandados o acompanhamento e o monitoramento dos produtos, serviços e respectivos processos produtivos, que deverão ser feitos de forma mais rigorosa, visando ao aumento da credibilidade dos fornecedores para com os clientes (VENTURA, 2010, p.06).

\subsubsection{CONSUMO DE BAIXA RENDA}

O ingresso de novos consumidores à economia de mercado tem ocorrido devido múltiplos fatores ligados a políticas públicas, entre eles estão o aumento real do salário mínimo, ampliação do crédito, a redução de IPI Imposto sobre Produtos Industrializados - e a criação e expansão de programas sociais. 
Com isso, milhões de brasileiros, desde 2002, aproveitaram os incentivos governamentais para ingressar na economia de mercado e vivenciar a experiência do consumo. . De acordo com pesquisa realizada pelo instituto Ipsos, em apenas dois anos, de 2005 a 2007, um contingente de 23,5 milhões de brasileiros deslocaram-se da base para o centro da pirâmide social. Esta ascensão social gerou um novo e surpreendente panorama brasileiro (Gráfico 3), pela primeira vez na História, a classe média passou a ser maioria no Brasil. Somada aos 29 milhões de pessoas que fazem parte das classes A e B, o Brasil já possuía em 2008 cerca de 114 milhões de brasileiros que podem ser considerados consumidores. Segundo o IBGE, O potencial de consumo da classe $C$ somou $R \$ 365$ bilhões em 2007, um quarto da capacidade total de compra de todas as famílias que moram nas cidades.

\section{Gráfico 3. Percentual das classes econômicas na população brasileira}

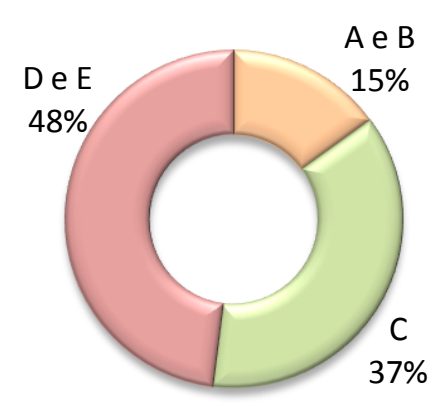

2002

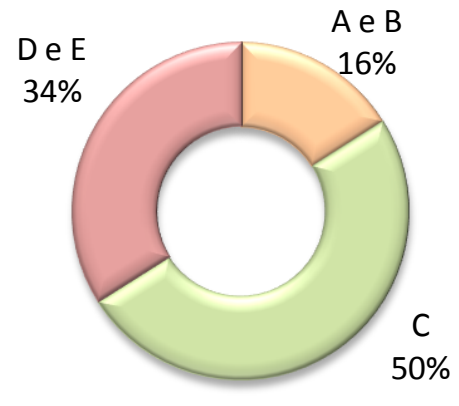

2009

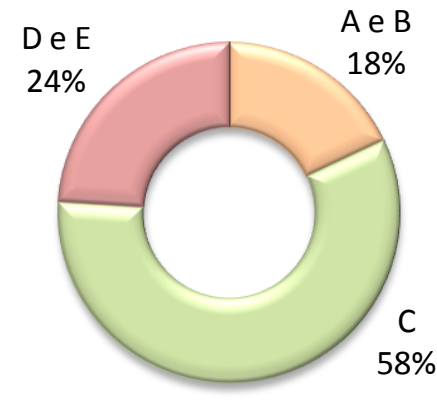

2014

Fonte: Elaborado pelo autor com base nos dados encontrados em http://blogdomassa.com/2014/09/11/faixas-salariais-x-classe-social-qual-a-sua-classe-

Com a ascensão das classes de mais baixa renda, há também um aumento da demanda por bens de consumo popular. Isso ficou claro quando ocorreu a redução do IPI, como forma de estimular as vendas e amortizar os efeitos da crise global, aplicada pelo governo em 2009 para produtos da linha branca - fogões, geladeiras, etc. - e as vendas no varejo cresceram $30 \%$ no mês seguinte a redução do IPI, em comparação ao mesmo período de 2008. Este aumento resultou a falta de produtos no comércio devido ao aumento impactante das vendas. 


\subsubsection{CONSUMO PRECOCE}

Cada vez mais as crianças e adolescentes tem exercido um maior papel na decisão de compra da família, sendo considerados como clientes potenciais. Isso se deve ao fato de que o público infanto-juvenil está se tornando adulto mais cedo, ou melhor, tem assumido hábitos de consumo mais precocemente, tanto devido às mudanças ocorridas na dinâmica familiar nas últimas décadas, quanto o impacto da tecnologia sobre o mundo infanto-juvenil. O autor McNeal (2000) reforça a realidade deste consumo precoce:

Hoje se consideram as crianças como consumidores de todos os tipos de serviços e produtos... As crianças representam um mercado primário de consumidores que gastam seu próprio dinheiro conforme seus desejos $e$ necessidades; um mercado de influência que orienta o gasto do dinheiro de seus pais em benefício próprio, $e$ um mercado de futuro de todos os bens e serviços que, se cultivados desde então, proporcionarão um fluxo constante de novos consumidores (MCNEAL, 2000, p.11 apud SANTOS, 2007, p.75).

Segundo pesquisa realizada pela InterScience e divulgada em $2007,80 \%$ das crianças brasileiras influenciam as compras de produtos, enquanto que, em 2000 , esse valor era de $71 \%$. O estudo ainda abordou o poder das crianças sobre a escolha de marcas, constatando que $98 \%$ dos pequenos são influenciados pela imagem de seus ídolos. A pesquisa ainda trouxe alguns outros dados importantes relativos ao comportamento de consumo das crianças, conforme é possível verificar no Gráfico 4: 
Gráfico 4.

Influência das crianças brasileiras na compra de produtos

Fonte: Estudo Kids Power InterScience 2007 apud VENTURA, 2010.

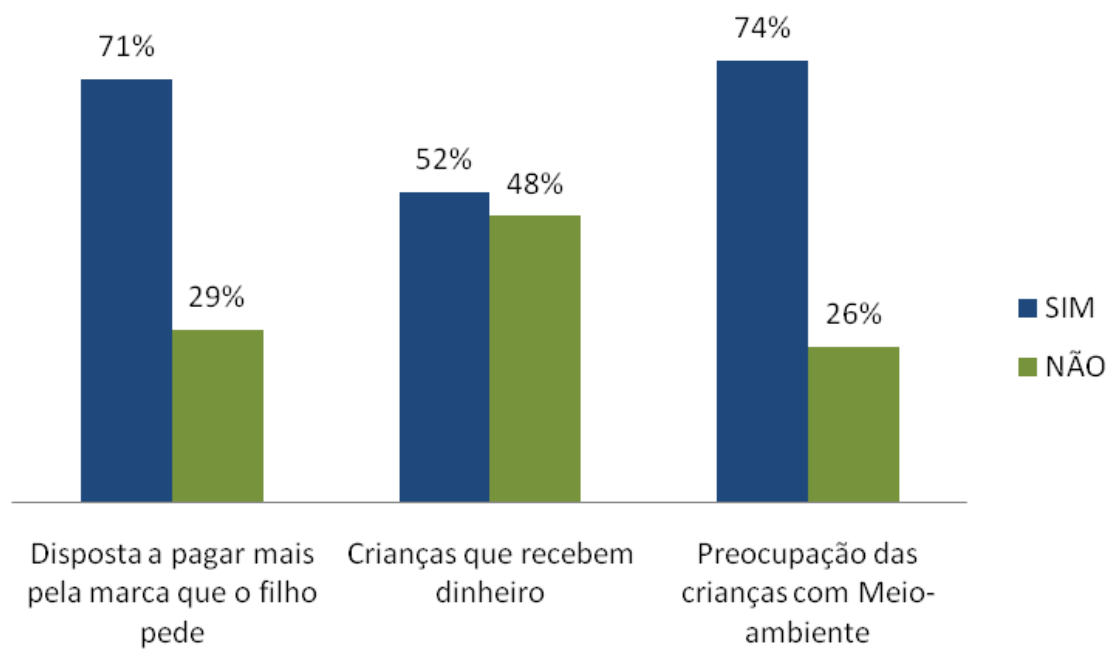

O estudo da InterScience vem complementar a pesquisa realizada pela agência de publicidade Young \& Rubican, que revelou que o público infanto-juvenil da faixa etária entre 0 e 14 anos, movimentam $R \$ 1,3$ bilhão por ano em mesadas administradas por elas mesmas, consumindo pequenos objetos e lazer (Sampaio, 2000: 152-153).

As novas situações familiares, o aumento da violência e a participação crescente da mulher no mercado de trabalho, são alguns dos fatores que tem contribuído para que as crianças permaneçam mais tempo dentro de casa. O tempo médio diário que crianças e adolescentes passam em frente à televisão tem subido constantemente desde 2004 e segundo dados do Ibope, houve um aumento de 52 minutos de 2013 a 2014. Segundo dados de 2015, este tempo médio contabilizado diariamente em frente a TV foi equivalente a cinco horas e trinta e cinco minutos.

O que vemos é um panorama muito favorável para a publicidade infantojuvenil. Não é à toa, que o consumo infantil tem faturado cerca de US\$15 bilhões por ano e, o poder de persuasão das crianças nas compras dos adultos aproxima-se de US\$600 bilhões (LINN, 2006 apud SANTOS, 2007).

Nesse contexto, a tecnologia passa a ter papel de destaque. A televisão, o computador e o telefone celular consistem em poderosos canais de comunicação que disseminam novos comportamentos e estimulam o consumo. A partir do instante em que crianças e adolescentes passam a ter acesso a este meio, mais precocemente produtos vinculados a tecnologias 
da informação e conhecimento, como celulares e eletrônicos, também passam a ser consumidos com maior intensidade por essa faixa etária.

Diante do exposto, torna-se uma realidade cada vez mais presente, a possibilidade do redirecionamento das estratégias de marketing das empresas, com intuito de alcançar este público, tão facilmente seduzível, mesmo que esta ainda seja uma questão bastante delicada, que esbarra em discussões éticas e da regulação da publicidade infantil.

\subsubsection{CONSUMO ONLINE}

Segundo dados da Comissão de Banda Larga pelo Desenvolvimento, da Organização das Nações Unidas, a população mundial que, ainda em 2015, não tem acesso à internet é cerca de 4 bilhões de pessoas, o que equivale a $57 \%$ da população mundial.

O relatório também traz dados sobre o Brasil, onde $57 \%$ da população utiliza a internet, sendo que $48 \%$ das residências brasileiras estão conectadas. No caso da internet móvel este número sobre para 78 entre 100 brasileiros com acesso.

A internet tem se tornado uma realidade e presente no cotidiano de grande parte da população brasileira. Os usuários buscam informações, se conectam a outras pessoas, fazem compras, estudam e, inclusive, trabalham utilizando a Internet. E por isso, a internet torna-se uma ferramenta fundamental para as empresas.

O comércio eletrônico de bens de consumo no Brasil em 2015 atingiu faturamento de $\mathrm{R} \$ 41,3$ bilhões, crescimento de 15,3\% em relação a 2014, de acordo com a Ecommerce. Para um setor que faturava algo ao redor de $\mathrm{R} \$$ 0,5 bilhões em 2001, este faturamento representa um extraordinário crescimento de mais em 10 anos (Gráfico 5). 


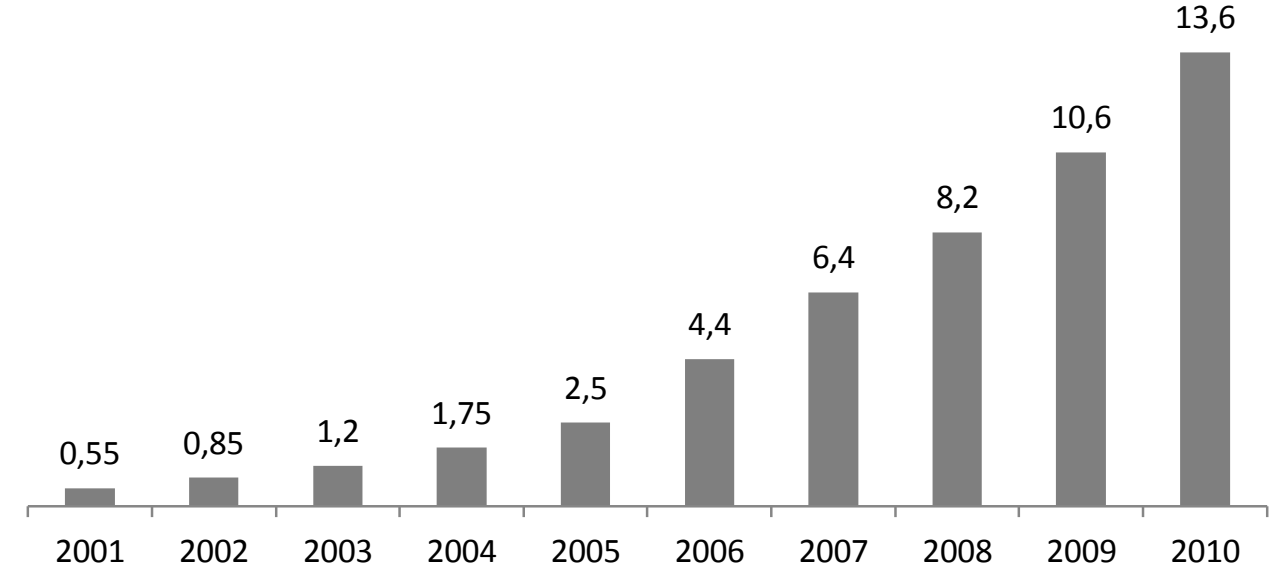

Diretamente proporcional ao crescimento do varejo online, encontra-se o aumento do número de consumidores. Em 2009, 17,6 milhões de consumidores já participavam do e-commerce, número 16 vezes maior quando comparado ao 1,1 milhão registrado em 2001. Segundo a Ecommerce, no período entre 2004 e 2007, os setores com maior expansão de vendas online foi o turismo, $62 \%$ ao ano, acompanhado pelo setor de bens de consumo, 38\% ao ano, e o de automóveis, 20\% ao ano. Em 2010 os produtos mais vendidos online foram livros, revistas e jornais (cerca de $21 \%)$ seguidos de artigos relacionados à informática (12\%), saúde e beleza (9\%), eletrônicos (7\%) e eletrodomésticos (6\%).

O perfil desse novo consumidor é bem diversificado, mas a maior parte é formada por adultos nascidos antes do boom da Internet e que tiveram que se adaptar a esta nova tecnologia. Sendo este perfil de usuário o maior realizador de compras online, imagina como será o panorama quando os jovens nascidos e criados junto com a Internet tiverem atingido a maioridade. Muito dificilmente estes não se tornarão e-consumidores no futuro, expandindo ainda mais o mercado e transformando o consumo online numa realidade cada vez mais concreta.

\subsubsection{CONSUMO PRÁTICO}

A falta de tempo é uma realidade do perfil do novo consumidor. Aliado a isso, surge uma demanda cada vez maior oriunda das pessoas que moram 
Gráfico 6.

Distribuição percentual das

unidades domésticas unipessoais por idade do

responsável

Fonte: Elaborado pelo autor

com base nos dados do

IBGE, 2010. sozinhas. Em torno de $12 \%$ dos 57 milhões de domicílios brasileiros são habitados por uma única pessoa, ou seja, um pouco menos 7 milhões de pessoas morando sozinhas no Brasil, segundo dados de 2010 do IBGE. A expectativa é de que este número aumente em 2016 para 12 milhões de pessoas.

Estas famílias unipessoais - definição presente no IBGE para pessoas que moram sozinhas - são compostas em sua maioria por pessoas de 40 a 59 anos, o que equivale a $34,5 \%$ (Gráfico 6). Isso significa que uma grande maioria de pessoas encontra-se na faixa economicamente ativa, o que, em termos de mercado, implica numa população com plena função produtiva e, por consequência, com maior poder de compra.

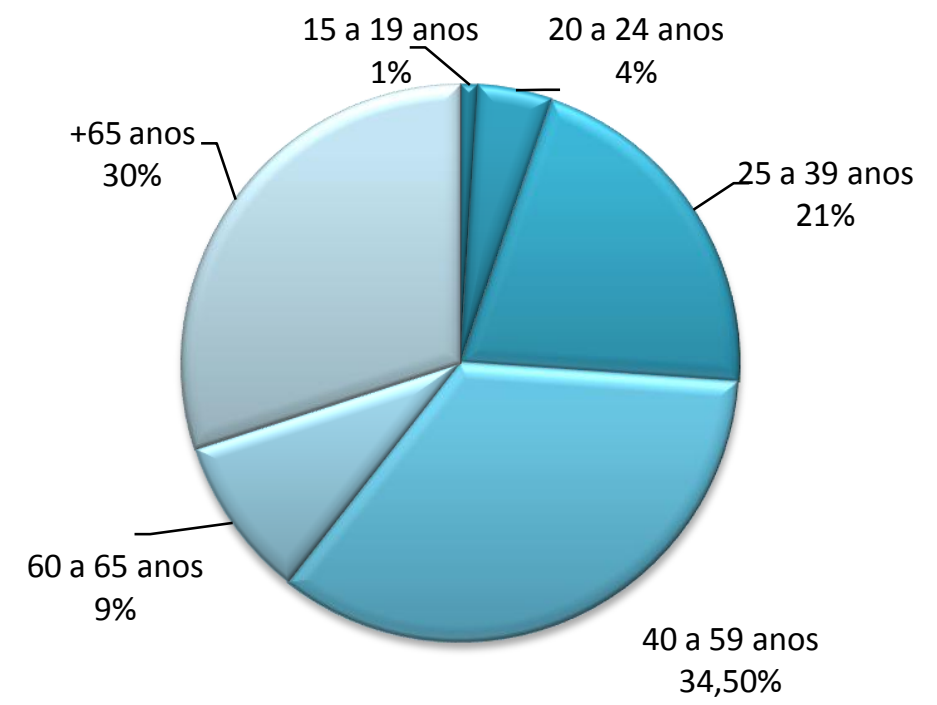

Das mulheres que moram sozinha, $40 \%$ são viúvas, enquanto os homens são em sua maioria solteiros, $58,9 \%$. Entender o perfil deste público tornase necessário, uma vez que as famílias unipessoais acabam por ter demandas e formas próprias de consumo de bens e serviços, em muitos casos, bastante diferenciadas de quem mora com outras pessoas.

Umas das principais necessidades envolve a otimização do tempo, a fim de conseguir conciliar as atividades pessoais e/ou profissionais com a administração do lar. Por esta razão, produtos ou serviços que possam facilitar as tarefas domésticas deste público têm grande chance de aceitação. Bem como, há uma crescente busca por produtos ou serviços que tarefas e compromissos extras. 
Segundo Ventura (2010), o consumo das pessoas que moram sozinhas vem crescendo em média $6 \%$ ao ano. Este público sozinho é responsável por $40 \%$ do aumento das vendas de produtos práticos e em porções individuais. O setor alimentício, por exemplo, tem sido impactado diretamente por essa tendência. Dados da consultoria Euromonitor indicam que a venda de pratos prontos congelados terá crescimento de 85,4\% entre 2013 e 2019.

De acordo com estudo publicado pelo Sicongel - Sindicato dos Congelados, Supercongelados, Sorvetes, Concentrados e Liofilizantes - o setor de alimentos congelados alcançou em 2014, um faturamento de $\mathrm{R} \$ \mathbf{1 0 , 9 8}$ bilhões, com um crescimento de 21,7\% acima de 2013 (Gráfico 7) o que a situa entre os segmentos de maior expansão da indústria brasileira da alimentação.

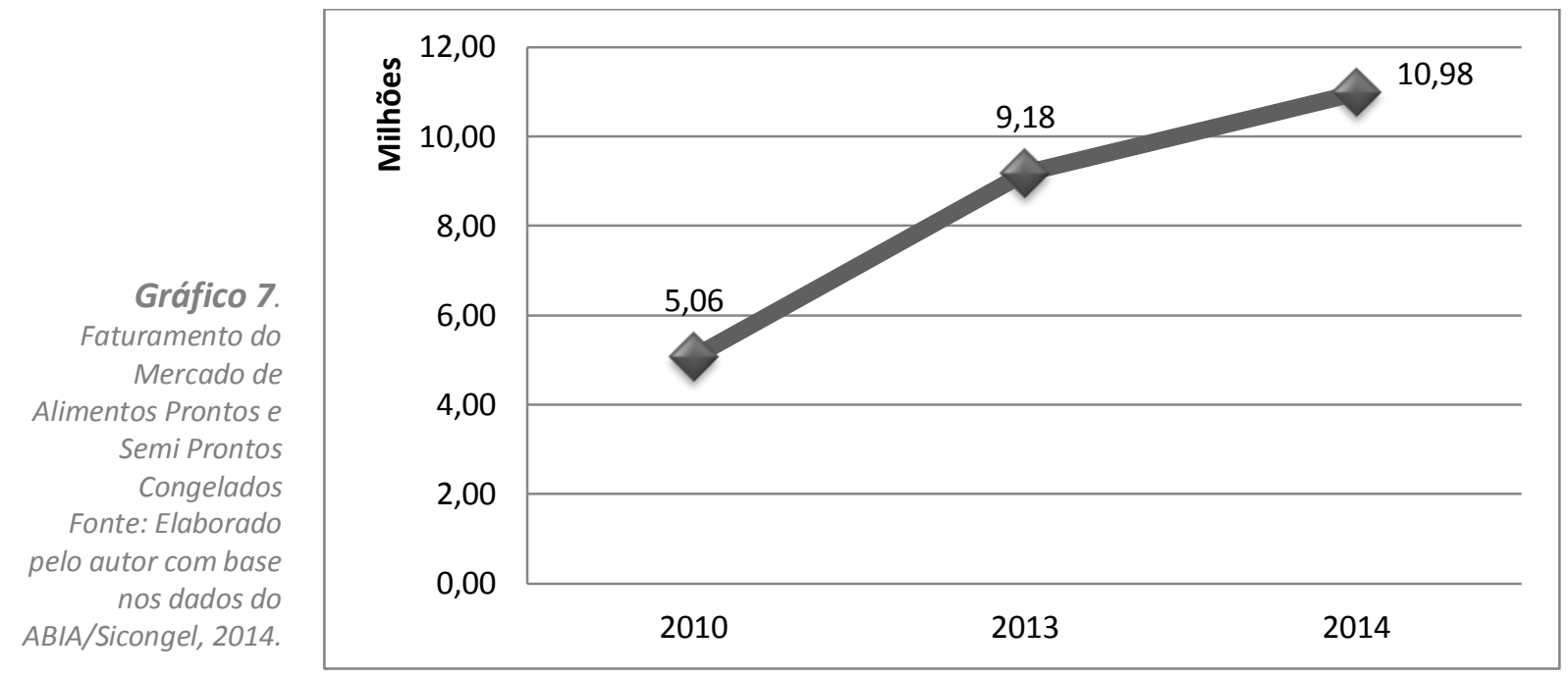

\subsubsection{CONSUMO EM NICHOS}

A emergência de mercados específicos voltados a determinados nichos de consumo tem tido resultados cada vez mais significativos e consolidados. Entre estes mercados ascendentes destacam-se aqueles voltados a portadores de necessidades especiais, homossexuais, produtos religiosos e afrodescendentes.

Segundo o censo de 2010, no Brasil, os portadores de deficiência já somam 45,6 milhões de pessoas, correspondendo a cerca de $23 \%$ da população 
Figura 18. Anúncio publicitário da Unimed Blumenau/SC veiculado em 2005

Fonte:

www.cafecomgalo.com.br/ publicidade-no-setorimobiliario-publico-alvo/

brasileira (IBGE, 2010). Trata-se de um mercado consumidor que movimenta anualmente $\mathrm{R} \$ 1$ bilhão, sendo $\mathrm{R} \$ 100$ milhões só com vendas de cadeiras de rodas e mais $\mathrm{R} \$ 400$ milhões no comércio de automóveis com isenção de impostos e adaptações veiculares (ROQUE, 2007).

Outro nicho que apresenta elevado dinamismo é o voltado ao público homossexual. $\mathrm{O}$ investimento com publicidade nos meios de comunicação dirigidos à comunidade GLS (gays, lésbicas e simpatizantes) nos EUA foi de 223 milhões de dólares em 2006, um aumento de 8\% em relação a 2004, segundo informações da consultora Primeaccess. Este é um fenômeno que também começa a ganhar força no Brasil, mas de maneira ainda muito tímida, sendo pontuais os anúncios publicitários que incluem tal público (Figura 18 e Figura 19)

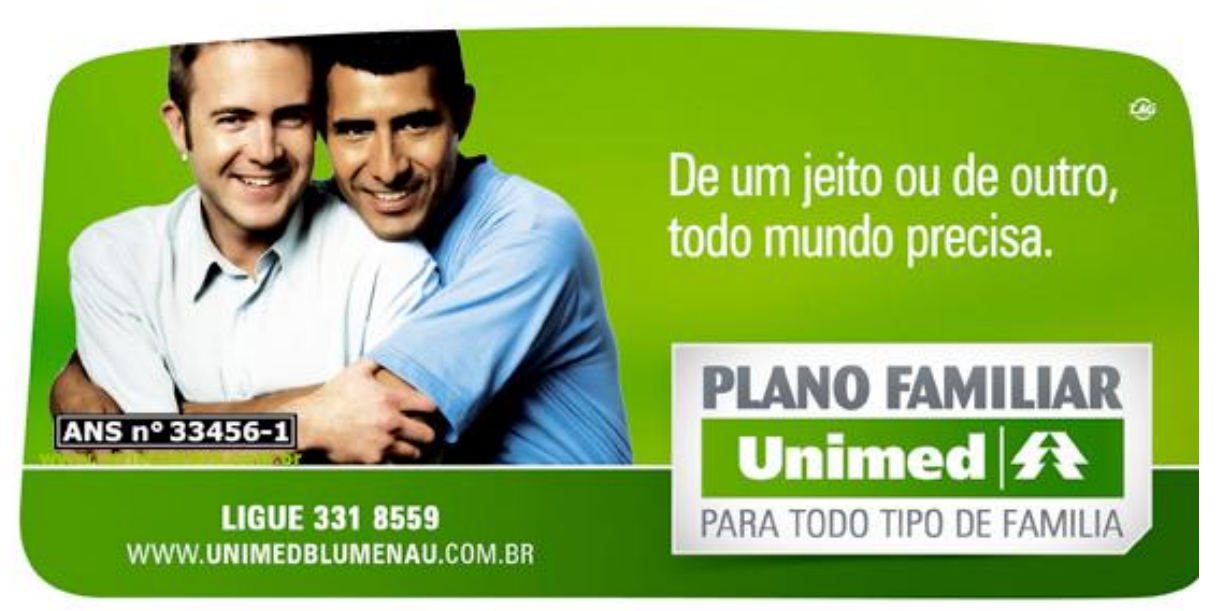

Figura 19. Anúncio da Tecnica divulgada em 2011 Fonte: www.cafecomgalo.com.br/ publicidade-no-setorimobiliario-publico-alvo/

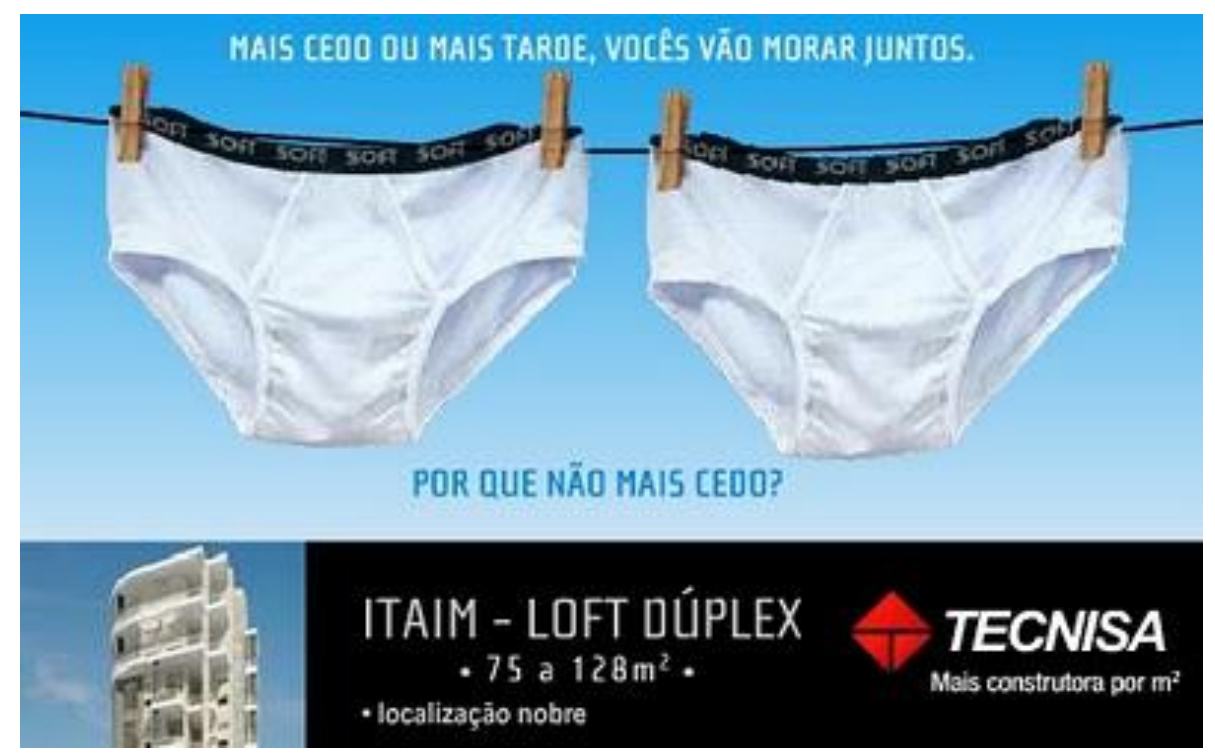


Dentre aqueles que se declaram homossexuais, $36 \%$ estão na classe $A$, enquanto $47 \%$ estão na B e $16 \%$ na C. Trata-se, portanto, de um público dotado de elevado poder aquisitivo, que deveria entrar no plano de mídia dos anunciantes, por ser um consumidor formador de opinião.

Há ainda outro nicho de mercado que tem recebido pouca atenção: os afrodescendentes. No Brasil, país com ampla diversidade étnica e cultural, $48 \%$ da população é parda ou negra. Segundo o IPEA, entre a classe socioeconômica mais rica, os negros e pardos representam 9,17\% e um terço de toda a classe média. Tendo em vista tais dados, é visível um crescimento na renda e, por conseguinte, no poder de compra entre os pardos e negros.

Os negros consumidores tem necessidades próprias, como identificação com suas raízes, ter produtos específicos para suas características e ser representada nos meios de comunicação. Com isso, vemos um crescimento de produtos destinados a este público. Só o segmento formal de beleza negra deve faturou em 2014 a quantia de $\mathrm{R} \$ 320$ milhões. Algumas empresas, como "O Boticário", já possuem maquiagens específicas para negras (Figura 20).

Figura 20.

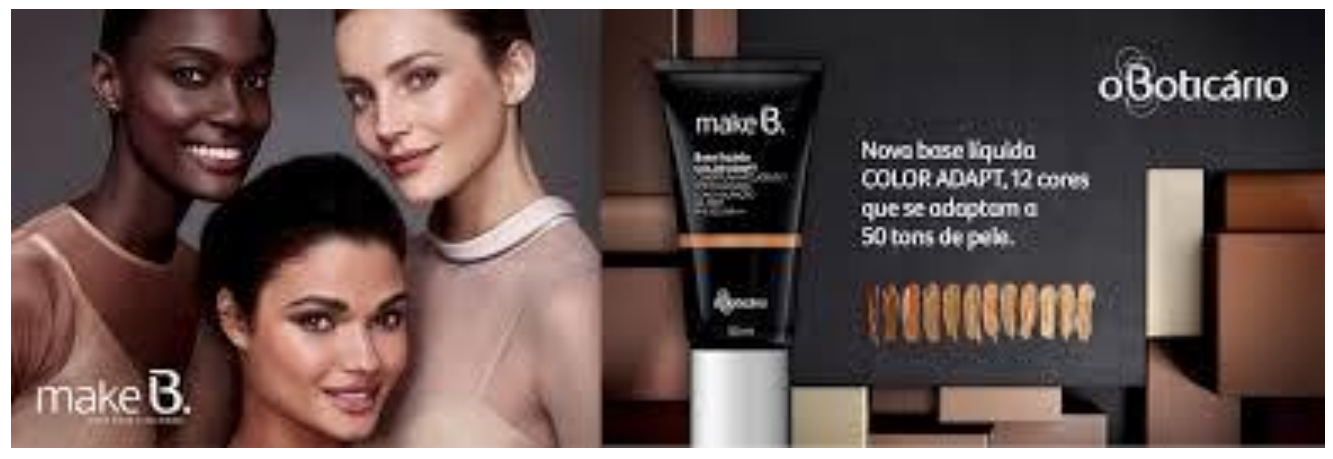

Outros setores também focam esse público, como o de brinquedos. A Estrela, tradicional fábrica de brinquedos brasileira, lançou bonecas negras (Figura 21) que tiveram uma venda acima das expectativas. 
Figura 21.

Bonecas negras da marca

Estrela

Fonte:
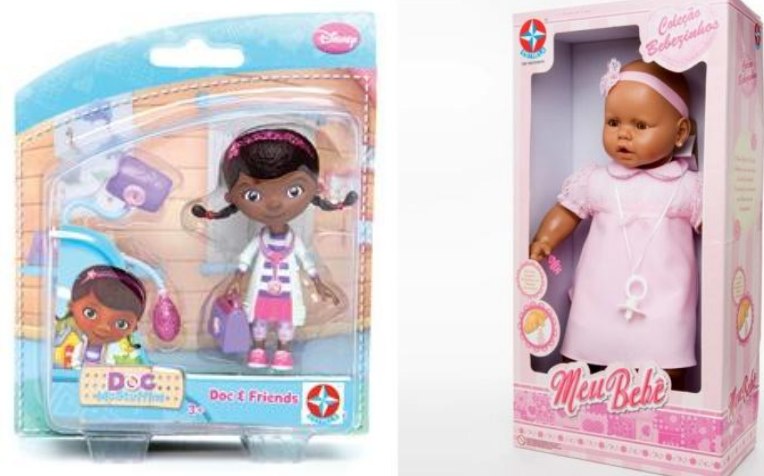

http://www.estrela.com.br/

Já no que se refere ao mercado de produtos religiosos, tem ocorrido um crescimento deste segmento em torno de $30 \%$ ao ano, gerando receitas de cerca de 15 bilhões de reais por ano, sendo 10 bilhões de reais apenas no segmento católico, de acordo com o instituto Data Popular. Já são mais de 900 empresas oferecendo todo tipo de produtos e serviços religiosos em todo o Brasil, oferecendo desde enfeite de geladeira até roupas (REBELLO, 2010). 


\section{Capítulo 3}

\section{Arquitetura comercial e as vitrines}

\subsection{UM PANORAMA DO COMÉRCIO VAREJISTA}

As novas formas de perspectivar o consumo e, por sua vez, o comportamento dos consumidores, discutidas no capítulo anterior, tem sido acompanhadas por mudanças significativas na concepção dos espaços comerciais e nas funções que os mesmos tem desempenhado. Na essência de sua função, os ambientes comerciais existem para que se vendam mercadorias. Porém, para que as lojas possam continuar a desempenhar com eficiência tal função, cada vez mais se torna necessário que estas ultrapassem a barreira de espaços de negociação, assumindo novos papéis.

Estas mudanças sempre estiverem presentes no comércio, uma vez que é da natureza do espaço comercial, que estes sejam espaços competitivos. Os comerciantes, por sua vez, para expandirem seus negócios ou simplesmente sobreviverem à concorrência, tiverem que se renovar constantemente, lançando novos produtos no mercado e/ou criando novas lojas e ambientes de consumo. Enquanto os consumidores, impulsionados por quaisquer que sejam as influências, culturais, sociais, pessoais e psicológicos, renovam continuamente seus desejos e necessidades, 
alterando seu comportamento e adotando novos estilos de vida, que impactam nas práticas de consumo.

Embora seja uma característica intrínseca ao comércio e ao contexto em que existem, as mudanças no ambiente comercial se aceleraram de forma impactante nas últimas décadas, trazendo profundas consequências à dinâmica de muitas cidades. Autores como Messerlin (1982 apud Cachinho, 2010), consideram que se tem vivido nas cidades a uma verdadeira revolução comercial. Tal revolução só fez se fortalecer de 1982 para cá, sendo visíveis seus impactos no setor econômico, na organização espacial, no significado das lojas e na forma como os indivíduos vivem, experienciam e se relacionam com a cidade através do processo da compra.

Tais mudanças, compartilhadas por muitas cidades, de diferentes contextos culturais e geográficos, alteraram a vitalidade e viabilidade econômica de diversas áreas comerciais. Com o crescimento das grandes cadeias de distribuição, houve um declínio dos pequenos comerciantes. O mesmo ocorreu com o comércio de bairro, que começou a perder força, frente à conveniência criada pela difusão dos estabelecimentos orientados para o uso do automóvel, bem como a desvalorização das lojas utilitárias e funcionais em relação às lojas espetaculares fundamentadas na lógica do fascínio e da atenção. Salgueiro e Cachinho (2009) reforçam tal pensamento ao afirmar que:

As relações da actividade comercial com a cidade sofreram naturalmente profundas mudanças ao longo dos tempos. Ao casamento secular construído com base na centralidade e na proximidade, a partir da qual os geógrafos estabeleceram um sistema hierárquico de áreas comerciais intra-urbanas, sobrevém um período em que acessibilidade e a facilidade de circulação $e$ estacionamento parecem critérios dominantes na seleção das lojas pelos consumidores, ao mesmo tempo que o comercio se desenrola em grandes espaços fechados e voltados para dentro, ignorando e negando a cidade pública feita de praças, avenidas e ruas coloridas, repletas de movimento, animação, luz e representação cênica, que tinha nos comerciantes e nos consumidores os principais protagonistas. (SALGUEIRO; CACHINHO, 2009, p. 10) 
A Tabela 2 pretende sintetizar algumas destas mudanças ocorridas ao longo dos anos 1950 até os dias atuais.

Tabela 2. Mudanças do perfil dos espaços comercias ao longo das últimas décadas

\begin{tabular}{|c|c|c|c|}
\hline Atributos & $\begin{array}{c}\text { Modernidade } \\
\text { (de } 1950 \text { a 1970) }\end{array}$ & $\begin{array}{l}\text { Pós-modernidade } \\
\text { (de } 1970 \text { a 1990) }\end{array}$ & $\begin{array}{l}\text { Hipermodernidade (Após } \\
\text { os anos 1990) }\end{array}$ \\
\hline Tipo de Loja & $\begin{array}{l}\text { Lojas tradicionais: } \\
\text { ancoradas numa } \\
\text { gama limitada de } \\
\text { bens e serviços; } \\
\text { - Hierarquizadas em } \\
\text { função das classes } \\
\text { sociais. }\end{array}$ & $\begin{array}{l}\text { - Novos formatos e } \\
\text { conceitos: centros } \\
\text { comerciais, megastores, } \\
\text { hipermercados; } \\
\text { - Segmentadas por estilos } \\
\text { de vida e valores } \\
\text { socioculturais. }\end{array}$ & $\begin{array}{l}\text { - Diversificação de } \\
\text { conceitos, espaços de } \\
\text { comércio e lazer, lojas de } \\
\text { experiências; } \\
\text { - Fragmentadas por temas } \\
\text { e experiências de } \\
\text { consumo. }\end{array}$ \\
\hline Oferta & $\begin{array}{l}\text { - Bens e serviços de } \\
\text { acordo com linhas } \\
\text { padronizadas; } \\
\text { - Determinada pelos } \\
\text { produtores. }\end{array}$ & $\begin{array}{l}\text { - Bens e serviços de acordo } \\
\text { com uma ampla } \\
\text { variedade de linhas e } \\
\text { nichos de mercado; } \\
\text { - Influenciada pelos } \\
\text { consumidores. }\end{array}$ & $\begin{array}{l}\text { - Bens, marcas, insígnias, } \\
\text { ambiências, experiências; } \\
\text { - Influenciada pelos } \\
\text { marketers, a ecologia e } \\
\text { outros valores sociais. }\end{array}$ \\
\hline $\begin{array}{l}\text { Estratégia de } \\
\text { Segmentação }\end{array}$ & $\begin{array}{l}\text { Preço e qualidade dos } \\
\text { bens e serviços. }\end{array}$ & $\begin{array}{l}\text { Valores socioculturais e } \\
\text { estilos de vida. }\end{array}$ & $\begin{array}{l}\text { Potencial dos signos dos } \\
\text { objetos/marcas e das } \\
\text { ambiências da compra. }\end{array}$ \\
\hline Alvo & $\begin{array}{l}\text { Satisfação de } \\
\text { necessidades }\end{array}$ & $\begin{array}{l}\text { - Satisfação de } \\
\text { necessidades e desejos; } \\
\text { - Realização de sonhos e } \\
\text { fantasias. }\end{array}$ & $\begin{array}{l}\text { Criação de espetáculo e } \\
\text { promoção de valores } \\
\text { sociais: convivência, } \\
\text { felicidade, ecologia... }\end{array}$ \\
\hline $\begin{array}{c}\text { Perfil dos } \\
\text { comerciantes }\end{array}$ & $\begin{array}{l}\text { Pequenos } \\
\text { comerciantes. }\end{array}$ & Cadeias de distribuição. & $\begin{array}{l}\text { Cadeias de distribuição e } \\
\text { comerciantes } \\
\text { independentes }\end{array}$ \\
\hline $\begin{array}{l}\text { Princípios de } \\
\text { localização }\end{array}$ & $\begin{array}{l}\text { Centralidade e } \\
\text { proximidade. }\end{array}$ & $\begin{array}{l}\text { Acessibilidade e facilidade } \\
\text { de estacionar. }\end{array}$ & $\begin{array}{l}\text { Espaços topológicos e hiper- } \\
\text { reais, lugares virtuais. }\end{array}$ \\
\hline $\begin{array}{c}\text { Significado dos } \\
\text { espaços comerciais }\end{array}$ & Espaços comerciais. & Lugares de consumo. & $\begin{array}{l}\text { Espaços e lugares de } \\
\text { experiências de vida. }\end{array}$ \\
\hline
\end{tabular}

Por muito tempo o processo de compra era apenas uma atividade básica ligada à satisfação necessidades. Foi apenas com o surgimento da sociedade de consumo (BAUDRILLARD, 1995), que ocorreram transformações radicais tanto no modo de organização do social, quanto nas relações que se constituem entre os indivíduos.

A sociedade de consumo é um termo utilizado na economia e sociologia, para designar todo tipo de sociedade que corresponde a uma avançada etapa de desenvolvimento industrial capitalista e que se caracteriza pelo consumo massivo de bens e serviços, disponíveis devido a produção massiva dos mesmos. 
Segundo Lipovetsy (2007), a sociedade de consumo teria se iniciado em 1880 e passado por diversas fases. Num primeiro momento, foi marcado pelo movimento de massificação das práticas consumistas. De 1950 até meados de 1970, teria sua marca na abundância e na redistribuição em massa dos bens, se constituindo como o período de consolidação de uma sociedade de consumo efetivamente massificada, até chegar à fase atual, onde as práticas consumistas se encontram desregulamentadas e descoladas de todo tipo de determinações. Hoje dia o consumo se constitui como essencialmente privado e tendo como suporte a experiência do consumidor, sua busca por satisfação, prazer e felicidade. Esta experiência tem caráter essencialmente emocional e é responsável por produzir uma dinâmica do "consumo para si".

A mudança nos paradigmas da humanidade é clara. Enquanto nossos antepassados se perguntavam, se o homem trabalhava para viver ou vivia para trabalhar, passamos a cogitar "se é necessário consumir para viver ou se o homem vive para poder consumir" (Bauman, 1999, p.89).

Com isso, Lipovetsky (2007) evidencia o processo de individualização crescente da atividade consumista, marcado pelo deslocamento do signo. 0 consumo como processo de significação deixa de ser voltado 'para o outro' e passa a ser orientado 'para si', em favor de um valor experiencial, no qual a relação com o objeto é agora o elemento determinante na motivação das práticas consumistas. Tal mudança envolve a retomada da centralidade do valor de uso dos bens como elemento predominante no interior destas práticas.

A imensa gama de bens e serviços disponíveis hoje no mercado e os impactantes ambientes comerciais de espetáculo, tornaram as compras numa experiência de lazer. O foco que estas adquiriram no cotidiano das pessoas e o fascínio despertado nos consumidores por algumas lojas estão transformando a sociedade de consumo numa verdadeira "cultura do consumo" (Morace, 1990).

Foi devido às alterações no modo de consumir do sujeito, que os espaços comerciais tiveram que se adaptar a nova realidade. Foram significativas as 
modificações na organização espacial das lojas. Num primeiro momento, as relações de conveniência proporcionadas pela facilidade de acesso e estacionamento, conduziram a uma descentralização da atividade comercial e num enfraquecimento enquanto espaços de compra exercidos pelos centros da cidade e bairros tradicionais. De acordo com Cachinho e Salgueiro (2010):

Nos tempos pós-modernos e hipermodernos, o interesse dos comerciantes reside sobretudo nas áreas suburbanas. Irrigados de vias rápidas, preços de solo incomparavelmente mais baixos e sem património construído a preservar, os subúrbios dificilmente encontram concorrentes à altura adequados à implantação dos mega projectos explorados pelos grandes grupos imobiliários com interesses na distribuição. (CACHINHO; SALGUEIRO, 2010, p.4)

Iniciou-se nesta fase a ruptura do comércio com as ruas e quaisquer outros espaços públicos da cidade. O fenômeno do Shopping Center começou a ganhar cada vez mais força nas cidades. Segundo Vargas (1995) havia no Brasil em 1968 apenas um shopping. Em um pouco mais de 20 anos já eram 71 empreendimentos deste tipo, sendo 9 só na capital paulista.

Para o usuário ir ao shopping era sinal de prestígio e embora os produtos tivessem um valor maior, os shoppings surgiam como uma forma de entretenimento para família, que ainda possuía a facilidade de ter estacionamento. De acordo com Vargas (1995, p.742) "os Shopping Centers foram o resultado de uma sequência de alterações que se processou na organização das áreas comerciais, visando responder às transformações da economia, e da cidade".

Um novo panorama surgiu com a expansão do capital varejista, a descentralização comercial e a multiplicação de shoppings centers nas cidades. Os espaços comerciais deixaram de ser simples espaços de troca para se transformar em lugares de consumo. Os consumidores não procuravam mais as lojas para satisfazer as suas necessidades de abastecimento, eles queriam algo a mais. Os mercados deram lugar aos supermercados - que foram absorvidos pelos hipermercados - com suas 
técnicas de self-service (autosserviços). Surgiram as Grands Magasins, lojas de departamento, segmentadas por estilos de vida e valores socioculturais.

Essa reestruturação na forma de enxergar os espaços comercias tem como base o simbolismo das mercadorias e das ambiências dos estabelecimentos. Esta transformação não constitui apenas uma mera figura de estilo, sem significado, mas muito pelo contrário, sintetiza todas as metamorfoses vivenciadas pelas lojas. Técnicas apuradas de marketing e design, através das quais se busca seduzir os usuários, visam transformar os estabelecimentos comerciais em mercadorias, destinadas a serem "consumidas" tal qual os produtos e marcas propagadas por esta.

Os espaços comerciais transformaram-se num objeto passível de ser consumido. Mais do que bens e serviços, através da arquitetura, do design, das ambiências, das marcas, das insígnias, do espetáculo e do simbolismo dos objetos, atualmente, um grande numero de estabelecimentos estão empenhados em proporcionar aos consumidores verdadeiras experiências de vida. Desta forma, as pessoas aliam a satisfação de uma necessidade de consumo com a realização de desejos, criando um verdadeiro espetáculo e promoção de valores sociais.

Esta mudança de paradigma do espaço comercial ocorre devido à sensação eterna de insatisfação. A dependência cada vez maior desta forma de experiência de felicidade atrelado ao consumo, está relacionada a necessidade primária de vivenciar uma experiência subjetiva e emocional, voltada para a felicidade e o bem-estar do indivíduo, que acaba sendo alimentada por esta relação felicidade e consumo.

O consumidor atual busca mais que uma compra, ele quer viver uma experiência de consumo, buscando experiências sensoriais variadas que aliam estímulos a estados emocionais, resultando numa resposta derivada de ambos. Neste sentido, há uma procura por novidades, enquanto fontes de prazer para evitar o tédio da repetição:

Hoje, o que se busca no consumo é, antes de tudo, uma sensação viva, um gozo emotivo, que se liga menos às exigências do padrão de vida que à própria experiência 
do prazer da novidade [...]. Comprar é sentir o gozo, é adquirir uma pequena revivescência no cotidiano subjetivo. Talvez esteja aí o sentido definitivo da engrenagem hiperconsumista (LIPOVETSKY, 2004, p. 121).

Cachinho e Salgueiro (2010) reiteram este pensamento, demonstrando como isso ocorre no espaço comercial. Eles acreditam que não há lugar na cidade contemporânea, que consiga agradar e seduzir os consumidores, sem oferecer uma experiência de vida. Segundo estes autores:

Um café, uma praça, uma boutique, a cidade em si, têm de se dirigir cada vez mais às pessoas não como simples lugares, mas como experiências activas. Parafraseando Welsch (1996), passamos o dia vivenciando experiências: de manhã deslocamo-nos para o trabalho para usufruir de um escritório-experiência, no final da tarde vamos às compras para desfrutar de uma shopping-experiência, $e$ porventura relaxar com uma gastronomia-experiência, $e$ ao fim do dia dirigimo-nos para casa para gozarmos de uma residência-experiência. Numa cidade onde tudo parece girar em torno do "consumo de espectáculos, de espectáculos de consumo, do consumo de signos e de signos de consumo" (Lefèbvre, 1969: 150), as experiências estão a transformar-se numa espécie de refúgio colectivo (CACHINHO; SALGUEIRO, 2010, p. 05).

O consumo de signos rege a lógica do mercado atual. Independente de serem criados, ou não, estes estão presentes em todos os lugares. Por isso, hoje, este é o foco da estratégia de segmentação das marcas, uma vez que seus códigos de identidade e valor vão se adaptando para seduzir o consumidor. Numa concorrência cada vez maior, os mercados de grande consumo se diferenciam através da criatividade, dos valores e ideias agregadas a da marca em oposição ao custo da mercadoria. O diferencial está em não se vender um produto, mas uma visão, conceito, estilo de vida que estão vinculados à marca (RODRIGUES, 2012).

O mesmo ocorre com os espaços comerciais. Numa tentativa de resposta a estes anseios tem crescido o número de lojas-conceito pelo mundo. $\mathrm{O}$ termo loja-conceito tem sido usado como tradução das expressões em inglês flagship store e concept store. Tais termos são utilizados para se referenciar a loja líder e exemplar da marca, onde sua essência estará representada de uma maneira inovadora, explorando um conceito para 
comunicar sua posição no segmento de varejo ao qual pertence. Mais do que gerar receitas diretamente, como ocorre em uma loja convencional no varejo, as lojas conceito possuem como objetivo principal impactar e encantar as pessoas com suas experiências. Plascak $(2008$, p.5) define a loja-conceito como "o espaço sensorial da marca, onde todas as suas manifestações falam a mesma língua e permitem uma relação direta com o cliente, através dos sentidos".

Além das lojas-conceito, existem os lifestyle centers - que são centros comerciais que combinam funções de varejo tradicionais de um shopping center com comodidades de lazer orientados para a experiência de compra - e as ruas comerciais com a concepção de shopping a céu aberto. Segundo Rodrigues (2012, p. 51) estas ruas:

Idealizadas como 'lugar de consumo' serão renovadas a partir de estratégias como inovação, horários flexíveis, campanhas e eventos promocionais, padronização visual, logomarca, tratamentos de fachadas alinhadas com a linguagem universal dos centros de compra planejados, a exploração político-cultural de suas identidades particulares, para melhor dizer sua autenticidade. Enfim, tudo aquilo que pode vir a promover novas experiências e elevar o número de possibilidades de uso do antigo-novo espaço faz parte agora da forma como as ruas comerciais serão organizadas, administradas e apresentadas para um consumidor ávido por novidades. (RODRIGUES, 2012, pg. 51)

A revolução comercial tem gerado em nossas cidades duas realidades. Enquanto um pequeno número de ambientes comerciais - que tem crescido exponencialmente - oferece experiências legítimas de vida ao consumidor, através da teatralidade das imagens e mercadorias, expostas em ambientes cênicos; há outra vertente, onde está a maior parte das lojas, que desprovidas de um valor simbólico significativo para os consumidores, continuam a funcionar como simples espaços de transação comercial. Este último grupo tem buscado lentamente uma reaproximação com a cidade. Em muitos países, o incentivo de iniciativas governamentais tem trazido consequências positivas para as ruas comerciais, que começaram a realizar uma gestão comercial coletiva, enfrentando de frente o declínio dos 
centros urbanos. No Brasil tem-se caminhando para resgatar a dinâmica social e econômica das áreas centrais em declínio, dando sinais, mesmo que tardios (comparado com as iniciativas de outros países), das primeiras tentativas de reconciliação com o urbano e também com o espaço público.

\subsection{CONCEITO E IMPORTÂNCIA DA VITRINE}

O primeiro fator observado por um usuário ao avistar uma loja é seu aspecto exterior: o local, o prédio e sua fachada. A fachada é a embalagem que envolve a construção onde a loja se encontra e funciona como um verdadeiro anúncio tridimensional da marca ali comercializada. Vitrines, esquadrias, placas, logos, toldos e acessos fazem parte desta composição.

As vitrines de rua funcionam como a ligação direta entre rua e loja e por tal motivo, elas contribuem para a construção do próprio espaço urbano. Elas são muitas vezes a imagem de uma cidade, podendo qualificar, ou não, o espaço em que se encontram. Tal fato se torna ainda mais visível nos centros urbanos, onde a presença marcante das atividades terciárias se transforma nos referenciais simbólicos das cidades (VARGAS, 2009). Tal pensamento é confirmado por DEMETRESCO (2004):

Nosso primeiro contato com uma cidade é por meio de sua arquitetura, seus anúncios de rua e suas vitrinas: as luzes da cidade somam-se à iluminação das suas vitrinas, espelho de seu viver, reflexos de sua vida, expressão de sua sociedade e de seu tempo. (DEMETRESCO et al.,2004, p.29)

Ao fazer parte da cidade, a vitrine se torna a estética dos espaços urbanos, podendo qualificar o espaço em que se encontram. Nela muitos profissionais se expressam, seduzindo, dialogando e interagindo com o público e a cidade.

As vitrines de rua ajudam a construir a imagem da loja como a do próprio espaço urbano, pois além de projetar a marca nela inscrita, as vitrines são uma forma de manifestar o imaginário social e um meio de entender as relações sociais de uma época. 
A vitrine estabelece uma comunicação direta com o consumidor e sua principal função é expor os produtos para atrair a atenção e despertar desejos. Nem sempre é fácil mensurar o êxito de uma vitrine ou sua eficácia na concretização da venda, mas de acordo com Demetresco et al. (2004), o olhar de um consumidor não permanece mais do que dez segundos numa vitrine e mesmo assim esta é a responsável pela maior concretização de vendas, cerca de $70 \%$.

Mais do que expor apenas produtos, as vitrines veiculam símbolos e signos culturais que estão associados à marca comercializada na loja e num segundo momento serão identificadas pelo consumidor. Segundo Sackrider (2009):

O consumidor se identifica à tematização que dá uma identidade própria à marca. É assim que as marcas comerciais exploram a segmentação do público, dirigindo-se a uma clientela exigente que procura encontrar traços de sua própria identidade no universo criado. (SACKRIDER et al., 2009, p. 15)

Isso porque, é através da vitrine, que se tem o primeiro contato físico com o consumidor, e com isso, se possibilita despertar um desejo ou necessidade, que pode ser real ou criada. O importante é que a exposição encante o observador a ponto de criar desejo pela mercadoria, persuadindo a comprá-lo. Na vitrine é possível criar uma história, informando a quem o produto poderá ser destinado e como poderá ser consumido, tendo papel importante nisso a marca ali comercializada que poderá incentivar ainda mais o desejo.

Através da vitrine, a loja pode informar como aspira ser reconhecida pelo seu público, seja pela sua política de preços, pela variedade de produtos que trabalha ou pela quantidade de produtos que expõe.

É interessante para a loja, que a vitrine surpreenda o observador, de modo a criar a cada instante novas soluções e alternativas que visem buscar um diferencial na exposição de determinados produtos (Figura 22). Na exposição de produtos deve-se conciliar aspectos estéticos, artísticos e técnicos, cujo objetivo principal é atrair a atenção do consumidor, o 
informando e, com isso, possibilitando que este conheça ou reconheça o produto.

Cada tipo de produto apresenta uma necessidade diferente de exposição. Cada mercadoria tem suas particularidades e dificuldades, que exigem cuidados que precisam ser respeitados e valorizados, mas quando conseguimos tirá-los do espaço óbvio, causamos um grande impacto para quem observa a vitrine.

Figura 22. Flores de chocolate da vitrine de uma confeitaria em Las

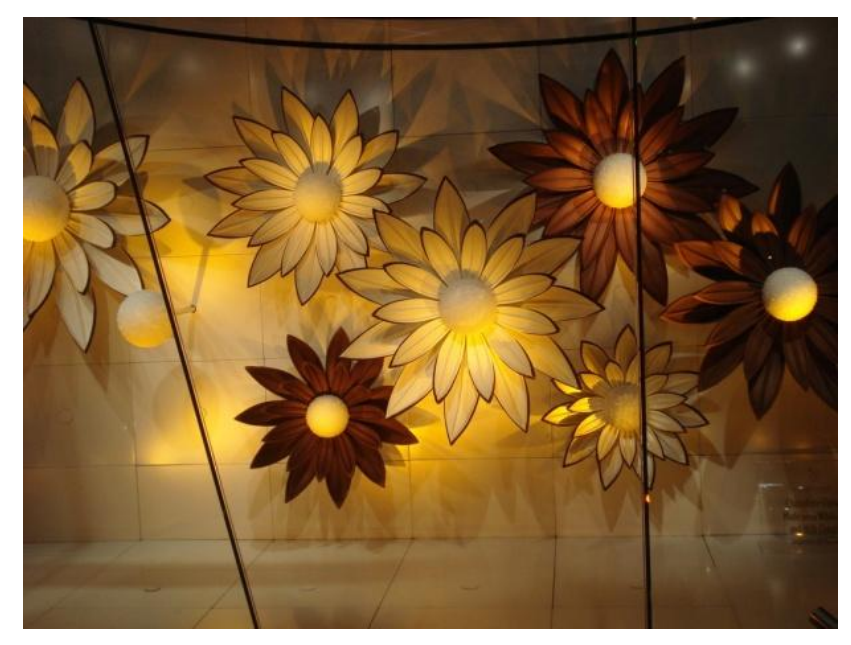

Além de local de exposição, a vitrine é local de evidência, de promoção visual de um produto, ou grupo de produtos, que tem o papel de expô-lo, mas também, segundo Lourenço e Sam (2011):

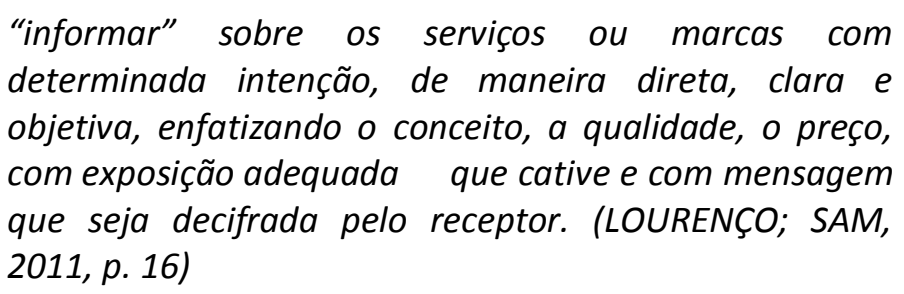
determinada intenção, de maneira direta, clara $e$ objetiva, enfatizando o conceito, a qualidade, o preço, com exposição adequada que cative e com mensagem que seja decifrada pelo receptor. (LOURENÇO; SAM, 2011, p. 16)

Entender a importância da vitrine enquanto estratégia de comunicação visual do ponto de venda é admitir a necessidade de se respeitar os diferentes tipos de exposição, até mesmo nos casos onde os mostruários não são utilizados. Os centros comerciais costumam ter bons exemplos de lojas que não possuem vitrines propriamente ditas. Toda a parte frontal da loja fica exposta ao público, induzindo os consumidores a entrar e circular livremente por esta. 
Independente do tipo de vitrine a ser utilizada, esta sempre vai funcionar como um grande convite à compra e por conta disso a importância de ser frequentemente renovada. Para Sackrider et al. (2009):

O ritmo de alteração das vitrinas varia em função do tipo de localização do ponto de venda: a cada dez ou quinze dias no centro da cidade, com mais frequência (toda semana) em um centro comercial. (SACKRIDER et al., 2009, p. 187)

A cada renovação, o mesmo espaço deverá sugestionar novidade, encantando o consumidor por meio de novos produtos, novas formas de exposição e/ou novas decorações. Mesmo quando a cartela de produtos comercializados é pequena, deve-se ter em mente novos arranjos espaciais para que seja transmitida uma sensação de novidade e desperte curiosidade e surpreenda o consumidor.

O importante é que se entenda que cada arranjo espacial criado irá transmitir informações ao observador. Em geral, serão transmitidos conceitos, que podem ou não ser bem recebidos pelo observador. Através da vitrine é possível identificar a cidade, estado ou país dos quais os produtos se originam, bem como o valor, estilo, tendência de moda, novas tecnologias, as características dos produtos e como esses poderão ser combinados e utilizados.

\subsection{ESTRUTURA DA VITRINE}

Uma vitrine, como qualquer espaço tridimensional, é composta basicamente por três partes: paredes, que são os painéis que compõem as paredes laterais, o vidro frontal e o fundo; o teto, que limita a sua altura e o piso, que pode ser simplesmente o piso da loja, ou um tablado que eleve e dê destaque.

O vidro frontal, as laterais, o fundo, o teto e o piso podem fazer parte dessa estrutura. Cada componente desenvolve um papel importante na vitrine e por este motivo, é adequado que seja explorada suas características de 
modo a aproveitar ao máximo toda a estrutura, para que a distribuição dos produtos fique mais adequada e mais visível.

As laterais tem a função de delimitar o espaço da vitrine, podendo ser usadas para fixação de algum aparato. Em geral, estas não são um componente principal em uma vitrine, uma vez que muitas vezes podem nem existir. Em lojas onde o fluxo de clientes é alto ou onde o produto apresentado na vitrine possui um alto valor econômico, a lateral pode ser utilizada como forma de segurança, já que isola os produtos do fluxo dos clientes e inibe que um furto ocorra de maneira inesperada.

Segundo Basso (2008), as laterais podem ser classificadas em praticáveis com painéis verticais que limitam o espaço; em ângulo - com painéis nas laterais que se fecham no fundo; móveis - possibilitam a subdivisão da vitrine ou simplesmente inexistentes, quando a vitrine é definida apenas pelo piso, teto e fundo.

Além das laterais, tem-se o fundo, que tem o principal objetivo de isolar a vitrine do restante da loja. O fundo limita a profundidade da vitrine e pode ser fixo, móvel, inexistente ou psicológico, e tal como as laterais, também pode não existir, deixando o interior da loja exposto. Quando esta não tem fundo, a loja por si só funciona como uma imensa vitrine. De acordo com Sackrider et al., (2009):

A escolha de uma loja visivel do exterior, que ofereça ao consumidor, logo à primeira vista, uma boa percepção do que tem dentro dela, implica garantir a ordem no ponto de venda com um rigor particular. Será necessário, ainda, cuidar para que o móvel do caixa seja dissimulado e que as vendedoras não indiquem que estão à espera de um cliente hipotético. (SACKRIDER et al., 2009, p. 185)

A vitrine sem fundo oferece a possibilidade de colocar perto dela artigos associados, ampliando a quantidade de produtos ofertada, porém é sempre um desafio para que esta não transpareça uma desordem e dê o destaque necessário para cada produto (Figura 23). 
Figura 23. Vitrine sem fundo da loja de acessórios ULM em

Florianópolis Fonte: Acervo pessoal da autora.

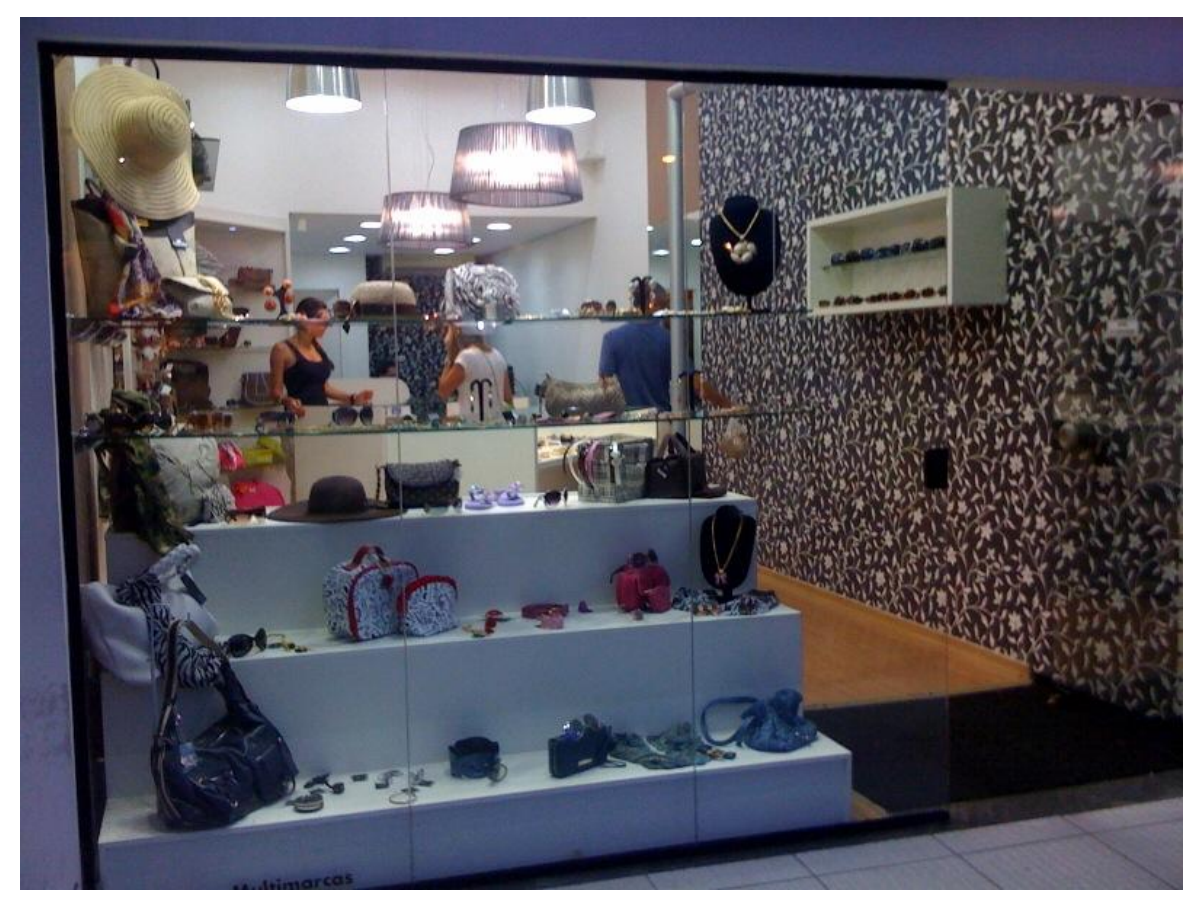

O fundo fixo é parte ativa integrante da vitrine, isolando-a completamente da loja e possibilitando uma superfície a mais para ser explorada. A principal vantagem em possuir um fundo é que este permite uma imagem mais "limpa" da vitrine, auxiliando que o produto tenha um destaque maior.

No caso do fundo móvel, a vitrine ganha uma flexibilidade maior, uma vez que se torna possível ampliar ou reduzir a profundidade ou variar a exposição da loja.

E por fim no fundo psicológico, utiliza-se de um artifício para que se tenha certo isolamento da vitrine com o restante da loja e com isso, permitindo um direcionamento de atenção ao produto. Na Figura 24 percebe-se que as águas-vivas criam um fundo, que não escondem totalmente a visibilidade da loja e mesmo assim trazem o foco do usuário para os produtos expostos nos manequins. 
Figura 24.

Vitrine da Loja Anthropologie em 2012.

Fonte:

http://www.brabbu.com/en/i

nspiration-and-

ideas/products/summerwindow-shopping-yes-please

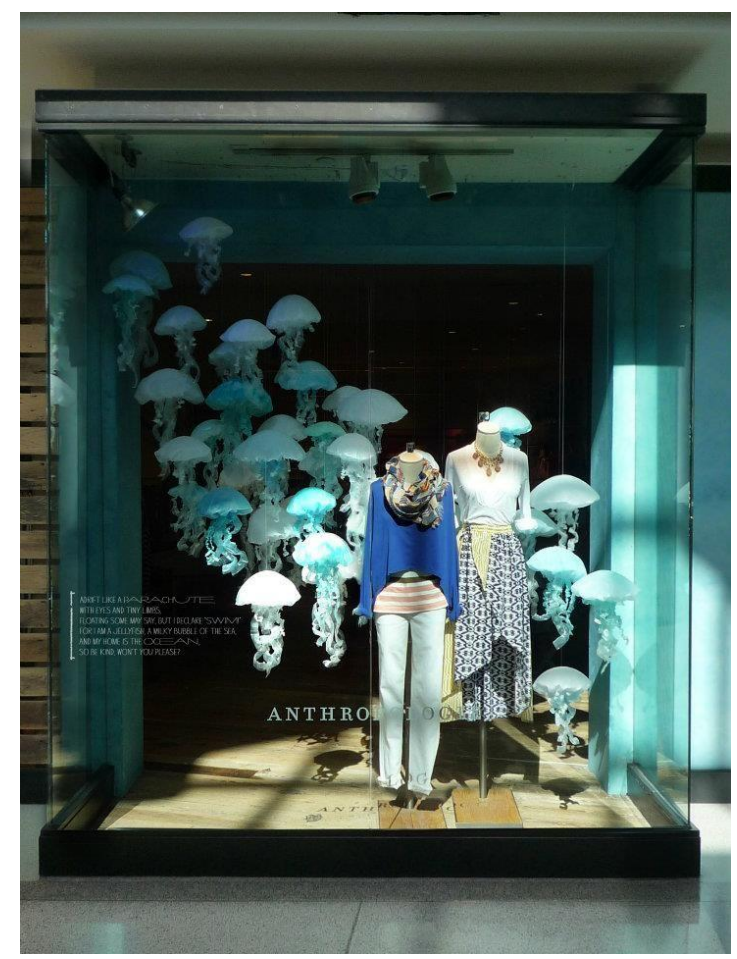

O fundo pode ser criado utilizando um painel ou até mesmo elementos como, peças de arte, móveis, molduras, banners, chapas de acrílico, cortinas ou o próprio produto exposto.

Já o teto limita o espaço da vitrine, em relação ao seu pé-direito e pode servir de suporte para fixação de elementos decorativos e até mesmo de suportes que servirão para a exposição de produtos (Figura 25).

Figura 25. Vitrine da loja Chanel em

Paris, onde o teto foi utilizado para fixar balanços que apoiam os expositores.

Fonte:

http://wgsn.tumblr.com/post /85027883174/rainbowbrights-and-anunconventional-swing-set

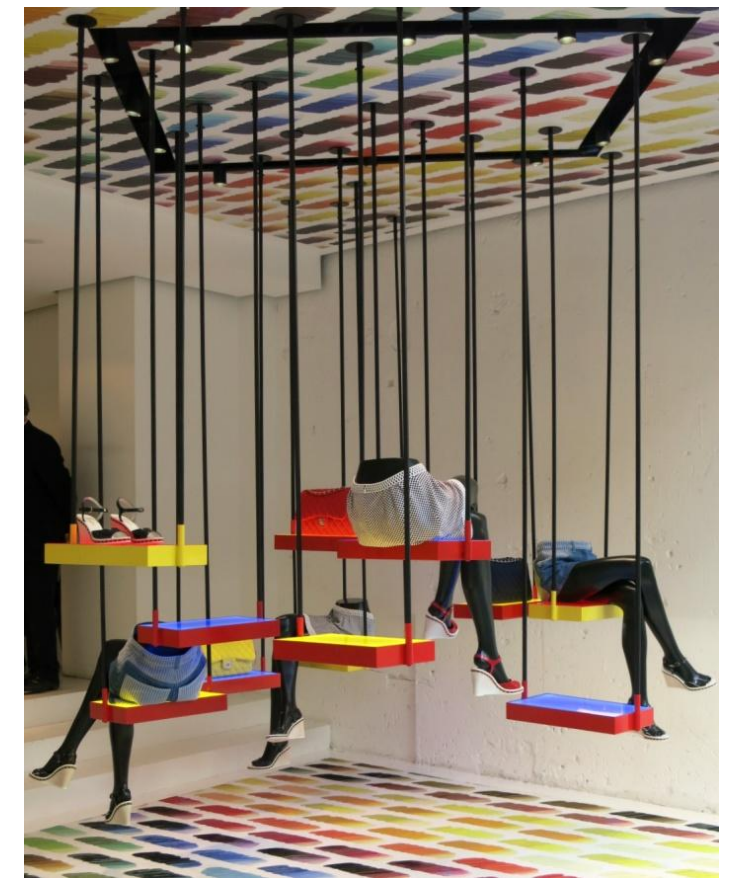


Por último, temos o piso que é a base sobre a qual os produtos ficam apoiados e por esta razão é considerado o principal elemento da estrutura. Além de limitar o espaço de circulação e de exposição, o piso tem como maior função destacar os produtos. Diante disso, não é aconselhável colocar os produtos diretamente sobre este sem destacá-lo, pois ao colocálos no chão reduzimos seu valor aparente e menosprezamos a mercadoria.

De acordo com Sackrider (2009) as características do piso da vitrine são inegáveis.

Se ele é mais alto em relação ao nível da rua, ou se a vitrina comporta um pódio, o destaque é dado aos produtos que ali são apresentados, já que o transeunte terá de levantar os olhos. Em algumas vitrinas, o piso, levemente inclinado para trás, cria um efeito de rampa. Os produtos ali dispostos se encontram assim tão visíveis como os apresentados no primeiro plano. (SACKRIDER et al, 2009, p. 186)

Para saber a altura ideal do piso da vitrine, uma vez que este pode estar tanto do mesmo nível que o piso da loja, quanto abaixo ou mais alto que este, é importante entender a melhor forma para se expor um produto, que será abordado no próximo capítulo.

Como estrutura da vitrine, poderíamos ainda considerar como um dos elementos o vidro, que isola o observador da vitrine e faz o fechamento frontal desta. $\mathrm{O}$ vidro também pode servir de suporte para decoração, mas o ideal é que sua utilização não impeça a visualização dos produtos e não cause poluição visual na vitrine. O importante é que independente do elemento a ser fixado, seja um desenho, uma frase, uma palavra, este faça parte do conceito e historia contada pela vitrine (Figura 26). 
Figura 26. Loja de departamento SteffI em Viena na sua inauguração. Fonte: $h$ ttp://www.stefflvienna.at/season-opening-2/

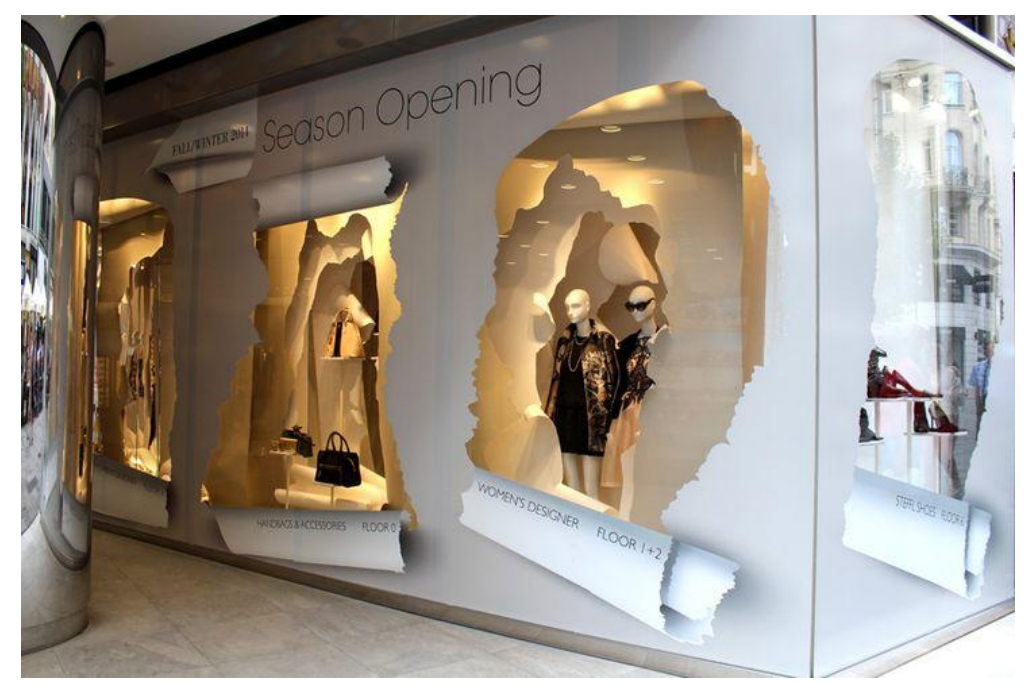

Em algumas situações, pode-se optar por esconder a vitrine (Figura 27), impedindo a visualização do produto, o que geralmente ocorre em vitrines ligadas a liquidações.

Figura 27. Vitrine da loja Schutz do Shopping Morumbi - São

Paulo.

Fonte:

http://www.adesivarts.com.b r/adesivos-paravitrine/envelopamento-vitrine

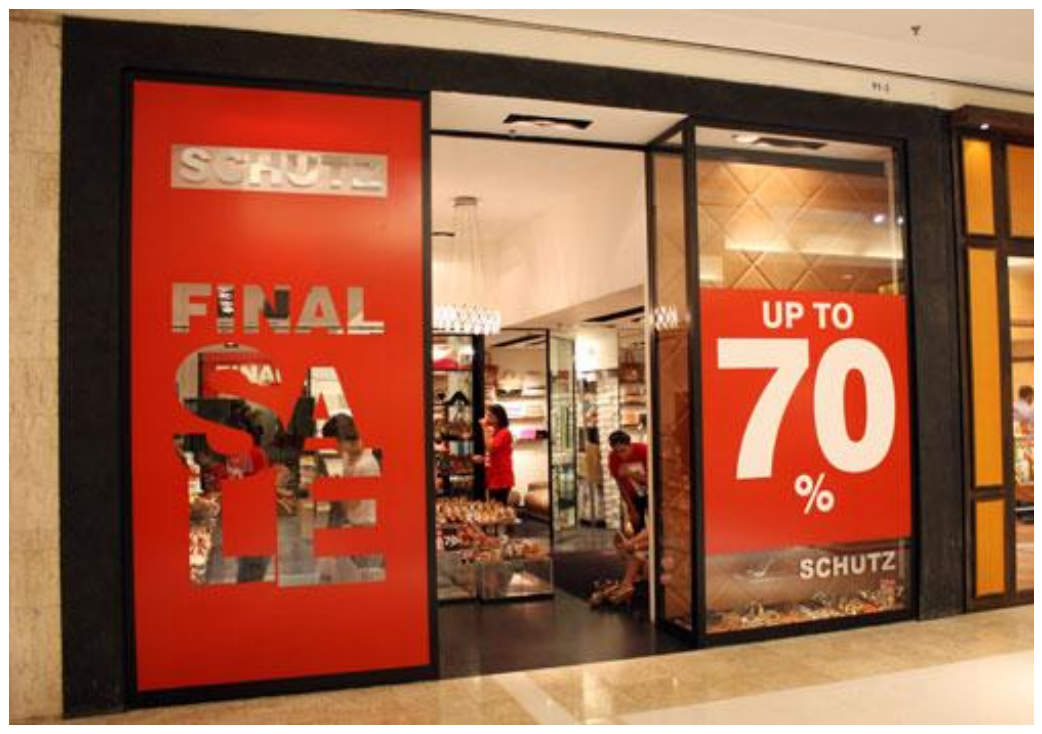

\subsection{TIPOS DE VITRINE}

As vitrines são os locais de atração inicial no ponto de venda e, para tanto, devem ser projetadas com o intuito de criar uma apresentação atraente, estimulando a atenção do cliente para a mercadoria que será exposta. É composta por diferentes partes que devem interagir de maneira 
harmoniosa para conseguir os resultados desejados na exposição dos produtos.

Uma vitrine pode possuir as mais distintas configurações, possuindo variações que dependem das condições estruturais, características da loja, localização, objetivos, tipo e quantidade de produtos expostos, temas abordados, os quais irão influenciar nas características que definirão, na maioria das vezes, os atributos que podem potencializar a atração do consumidor.

A localização de uma loja, se esta é dentro de um Shopping Center ou na rua, por exemplo, as dimensões e estrutura da vitrine podem trazer empecilhos para a disposição dos produtos. Isso é recorrente, principalmente nos centros históricos, onde prédios tombados pelo patrimônio histórico, os quais possuem restrições para alterá-los, tem que ser adaptados ao uso comercial (Figura 28).

Figura 28. Prédio comercial localizado no centro histórico de Florianópolis Fonte: Acervo pessoal da autora.

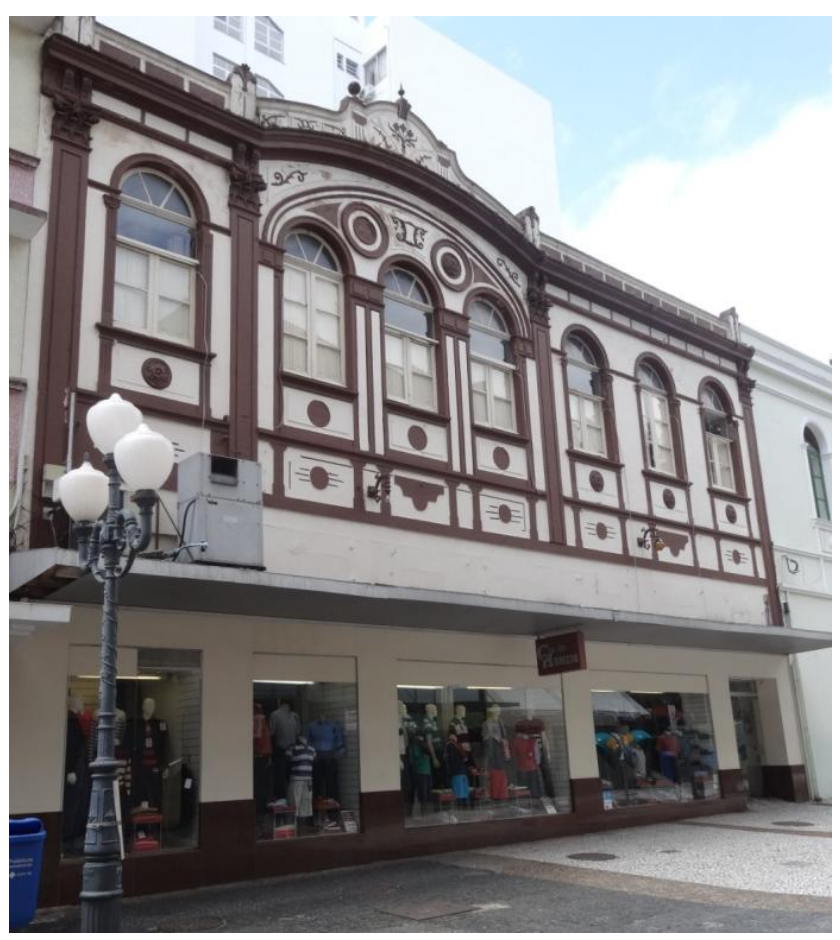

Nos casos onde temos a presença de vitrine, Lourenço e Sam (2011) as classificam em duas categorias: externas e internas. A seguir serão apresentados os diversos tipos de vitrine e suas aplicações. 


\subsubsection{VITRINES EXTERNAS}

As vitrines externas são as que estão presentes nas fachadas dos estabelecimentos comerciais. Entre as classificáveis como externas, estão as vitrines abertas ou fechadas, frontais, tipo corredor e mostrador.

Quando não há barreiras entre o fundo da vitrine e o restante da loja, a vitrine é considerada aberta. Elas podem ou não ter paredes laterais, mas necessariamente constitui-se como espaço único para e exposição, unificando os espaços da loja, tornando a própria loja uma grande vitrine. Segundo Lourenço e Sam (2011):

Esse tipo de vitrina costuma aumentar as vendas, porque deixa o público mais à vontade para entrar na loja, já que possui um tipo de estrutura que facilita a interação com o cliente. (...) Essa propriedade faz com que a vitrina aberta também atraia o consumidor pelos estímulos internos que a loja apresenta. Isso pode acontecer quando for trabalhado o visual merchandising em pontos estratégicos de PDVs que, mesmo estando no interior da loja, contribuirão para chamar a atenção de quem observa a vitrina. (LOURENÇO; SAM, 2011, p. 43)

As vitrines abertas (Figura 29) permitem uma integração visual do observador com o restante da loja e, por tal motivo, tornam-se uma preocupação para que todos os elementos estejam em harmonia, pois o consumidor poderá visualizar e saber o que está acontecendo dentro da loja, sem nem mesmo adentrar ao estabelecimento.

Figura 29.

Vitrine aberta de uma loja do

shopping Iguatemi Fonte: Acervo pessoal da autora.

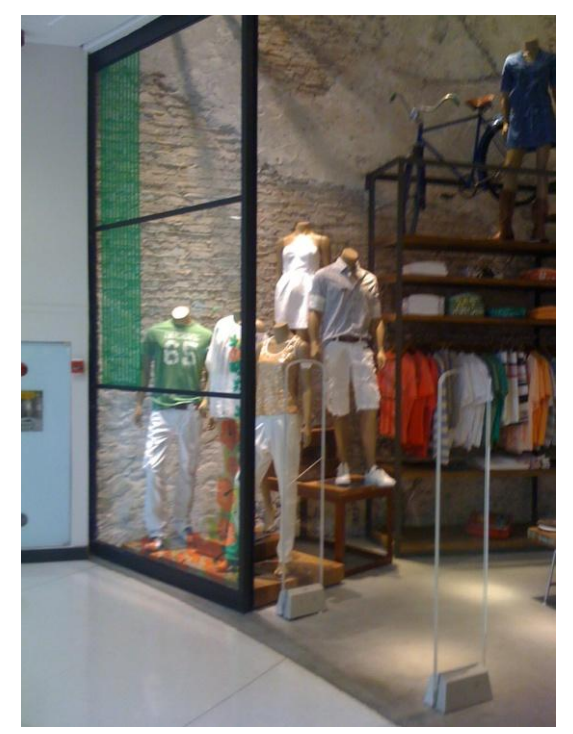


Existe ainda a categoria das vitrines abertas que estão completamente expostas ao público (Figura 30), não possuindo um vidro que impeça o observador de interagir com os objetos expostos. Este tipo se torna um convite escancarado para que o consumidor penetre na loja, pois ao tirar a barreira física, é eliminado também qualquer empecilho que possa afugentar o usuário.

Esse tipo é muito utilizado em lojas populares, bem como nas localizadas em shopping centers, com o objetivo de criar fluidez entre o espaço da loja e o do entorno, reduzindo ao máximo possível a transição entre eles.

Figura 30. Vitrine aberta de uma loja de rua de Florianópolis. Fonte: Acervo pessoal da autora.

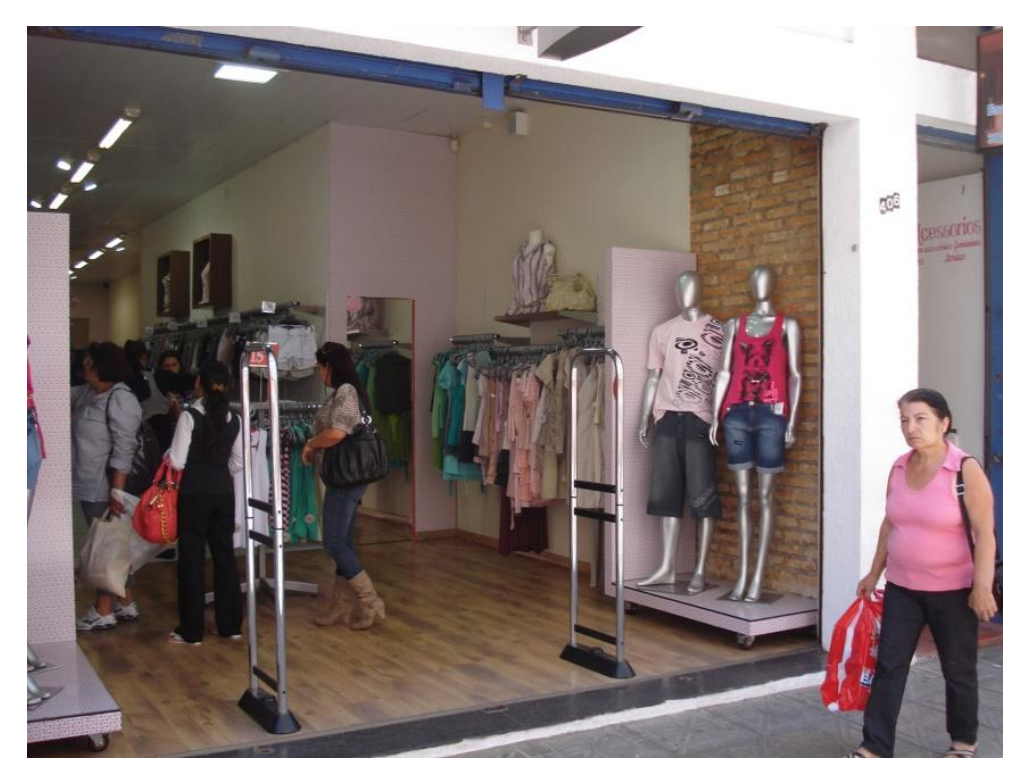

Diferente das vitrines abertas, as fechadas geralmente possuem um grande pano de vidro na parte frontal e uma parede ao fundo (Figura 31). Tal tipo de vitrine tem a particularidade de possui um plano limitando sua profundidade, que pode ser fixo ou móvel. De acordo com Pinto (2005):

Em certos casos, esse tipo de loja pretende transmitir a sensação de sofisticação e exclusividade de seus produtos. Tais valores têm se somado à segurança do recinto e à privacidade do cliente no caso de lojas como as joalherias, sejam localizadas em shopping centers ou na rua. A vitrina fechada também permite outro tipo de comunicação, com a possibilidade de elaboração cenográfica, iluminação especial, painel de fundo e um espaço delimitado capaz de abrigar um cenário especial. (PINTO, 2005, p.77) 
Figura 31.

Vitrine fechada de uma loja do Shopping Iguatemi Fonte: Acervo pessoal da autora.

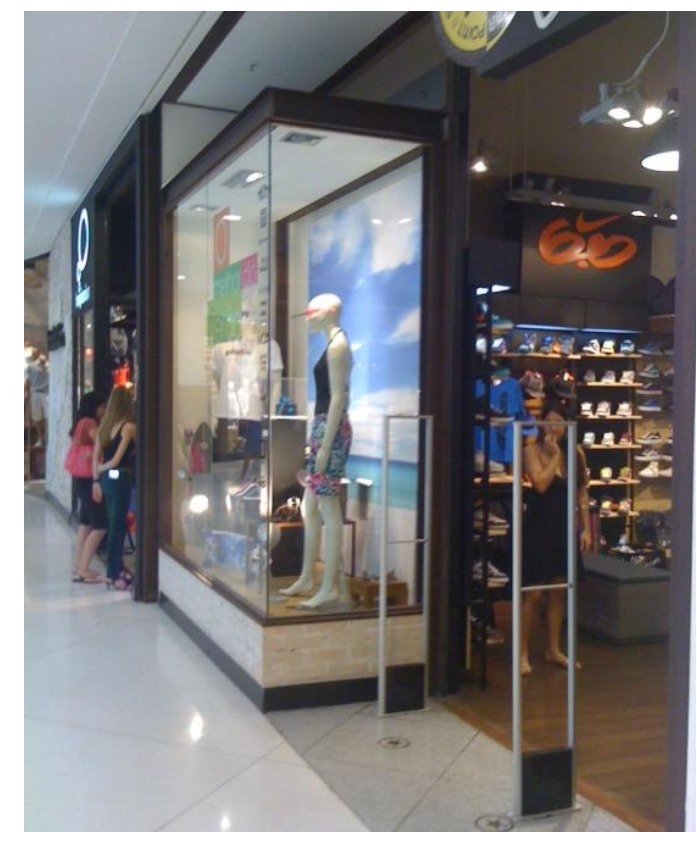

Tanto as vitrinas abertas, quanto as fechadas podem ser frontais, que são as vitrines que estão diretamente expostas na fachada do estabelecimento comercial e no caso das lojas de rua são as que separam a calçada do interior da loja.

Ocorrem ainda situações, onde as vitrines mesmo sendo frontais, possuem uma entrada recuada (Figura 32), criando um percurso onde o consumidor acaba tendo contato com mais superfícies expostas até chegar literalmente à entrada da loja.

Figura 32. Vitrine frontal com entrada recuada Fonte: BASSO, 2008.

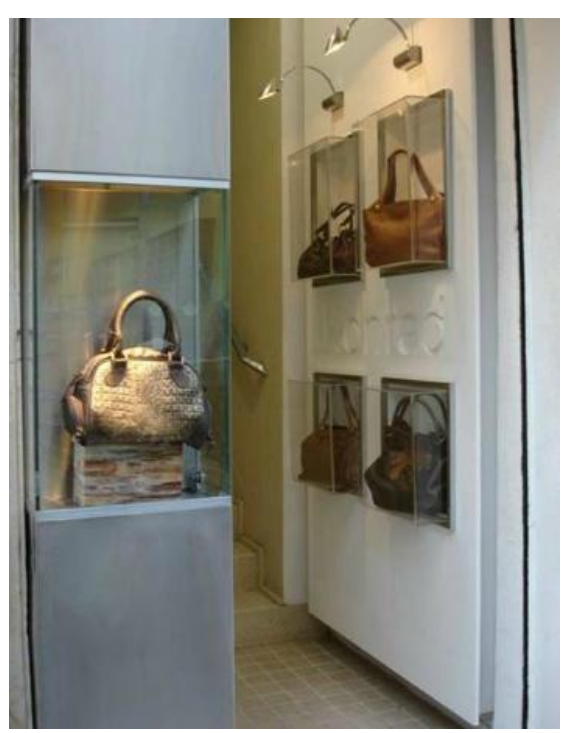


As vitrines frontais podem ainda ter uma configuração especial, quando estão localizadas em esquinas. Nestes casos os produtos expostos conseguem ser visualizados por diferentes ângulos. Isso ocorre, por exemplo, na loja Riachuelo de São Paulo/SP (Figura 33). Inaugurada em novembro de 2013, a Riachuelo, abriu sua primeira loja-conceito localizada na esquina da Rua Oscar Freire com a Haddock Lobo. A loja de três andares conta com 1.200 metros quadrados construídos e já abrigava outro estabelecimento comercial antes da Riachuelo.

Figura 33. Loja da Riachuelo na Oscar Freire em São Paulo Fonte: Acervo pessoal da autora.

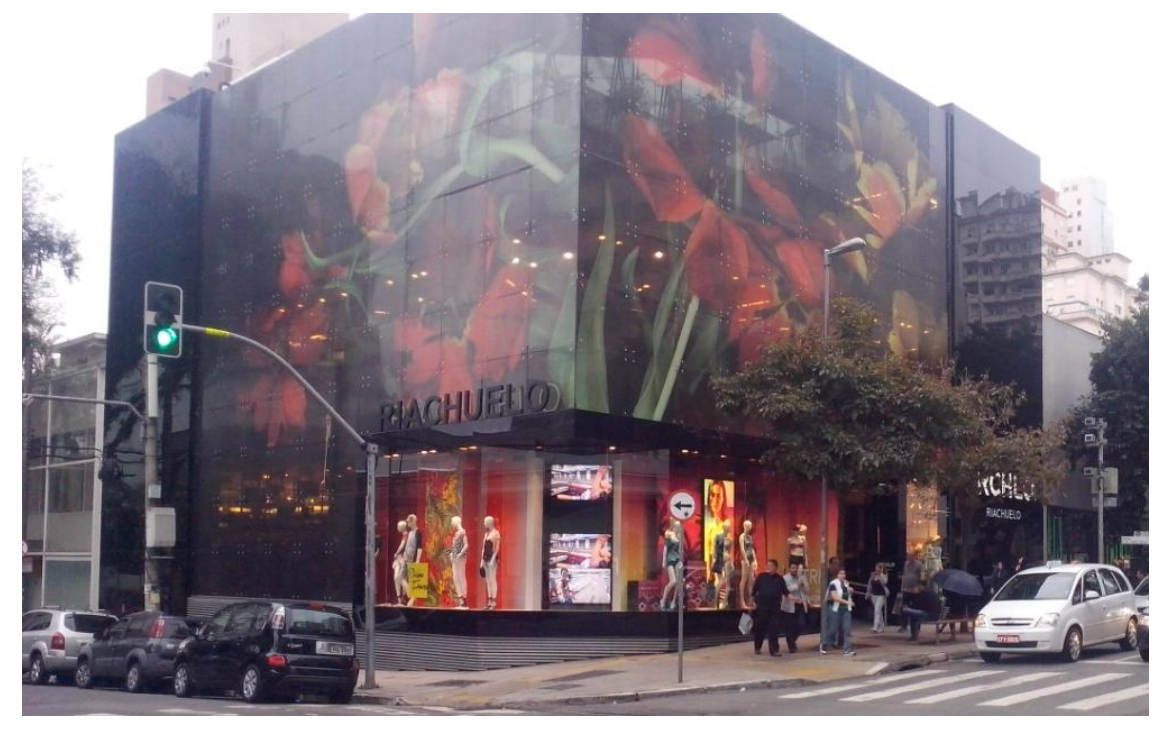

Além da vitrine frontal, tem-se a corredor (Figura 34). Este tipo é posicionado estrategicamente ao longo da entrada da loja, numa tentativa de encaminhar o cliente para se interior. A vitrine corredor facilita a abordagem do vendedor, uma vez que o limite de "dentro" e "fora" da loja é tênue.

Figura 34. Loja de calçados com vitrine corredor localizada no centro de Florianópolis Fonte: Acervo pessoal da autora.

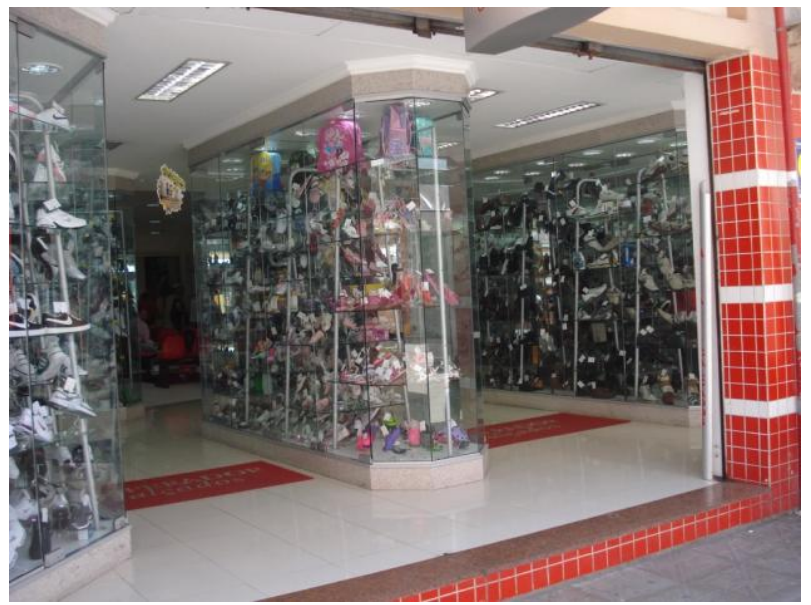


Este tipo de vitrine foi explorada na livraria da Vila (Figura 35) em São Paulo, que possui ainda a vantagem de manter uma comunicação com o consumidor, independente do horário comercial. Projeto de Isay Weinfeld, a vitrine possui o diferencial de ser móvel e se abrir para o interior da loja, transformando-se numa vitrine corredor.

Figura 35. Livraria da Vila aberta e fechada - São Paulo/SP

Fonte:
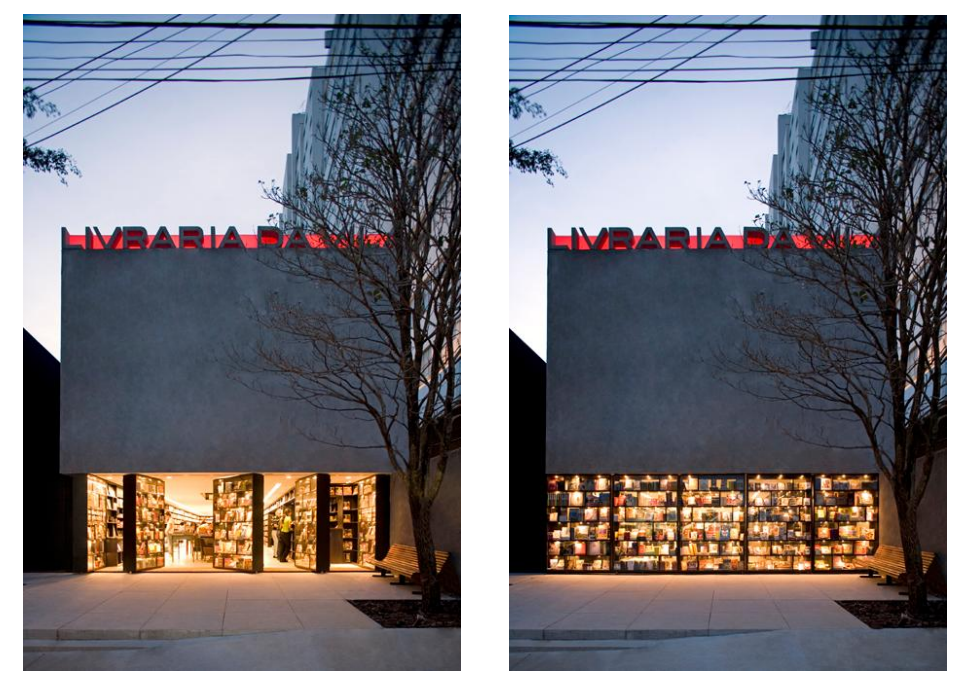

Lourenço e Sam (2011) elencam ainda como tipo de vitrine externa a tipo mezanino (Figura 36), que estão localizadas acima do ponto focal do observador e tem a função de atrair a atenção do consumidor a longa distância. Neste tipo de vitrine deve-se preferencialmente utilizar produtos de grandes proporções ou com exposições cenográficas. As vitrines tipo mezanino funcionam muito bem em situações onde o estabelecimento comercial encontra-se numa via com baixo fluxo de pedestres e o principal usuário será o que passará motorizado pela loja. Desta forma, toda a comunicação visual deve ser maior, para que possibilite uma fácil leitura, considerando a velocidade da via, e, desta forma, alcance de bons resultados. 
Figura 36. Loja Forma em São Paulo Fonte: http://www.designboom.com /interviews/paulo-mendesda-rocha-interview/

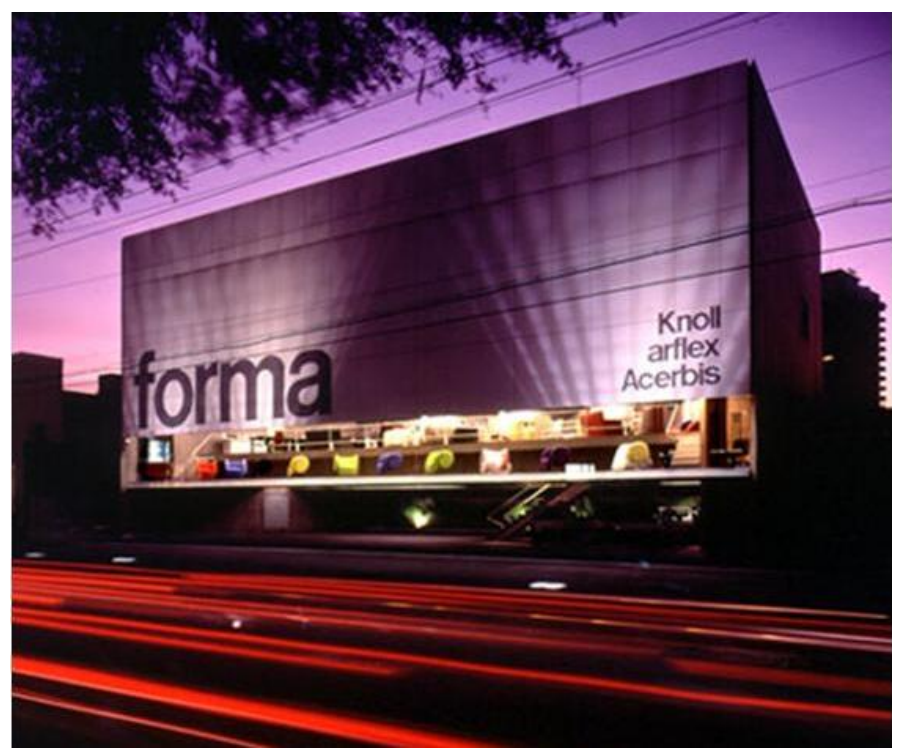

Há ainda as vitrines suspensas (Figura 37), também denominada de vitrines mostradores ou Shadow Boxes. Estas são vitrines mais altas que as demais, comumente utilizadas por lojas que comercializam produtos de menor tamanho, como joias, relógios, perfumaria, cosméticos, entre outros. A exposição dos produtos fica na altura dos olhos ao longo da parte frontal da loja e servem para aproximar a mercadoria pequena do campo visual do consumidor, dando destaque às peças e com isso, atraindo a atenção para aquele ponto.

Figura 37. Vitrine suspensa da loja de joias H.Stern do shopping Iguatemi Florianópolis Fonte: Acervo pessoal da

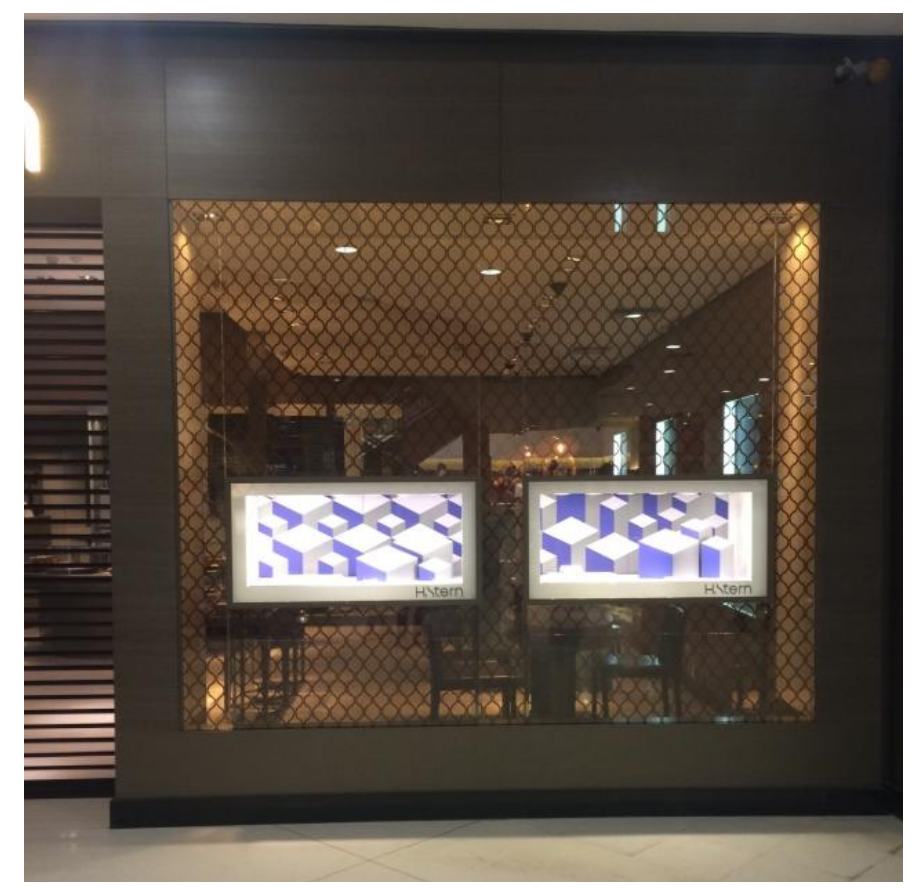




\subsubsection{VITRINES INTERNAS}

As vitrines internas ocorrem dentro dos estabelecimentos comerciais e podem ter múltiplas configurações (Quadro 1).

As vitrines centrais ou ilha podem estar localizadas nos centros das lojas, em estandes, em quiosques de shoppings centers ou em qualquer outro lugar que permita a comunicação com o consumidor. Estas permitem uma visualização do produto por diversos ângulos, dando na maioria dos casos uma visão em 360 o daquilo que está exposto. Sua altura pode varia conforme o tamanho do produto e do espaço de que a loja dispõe.

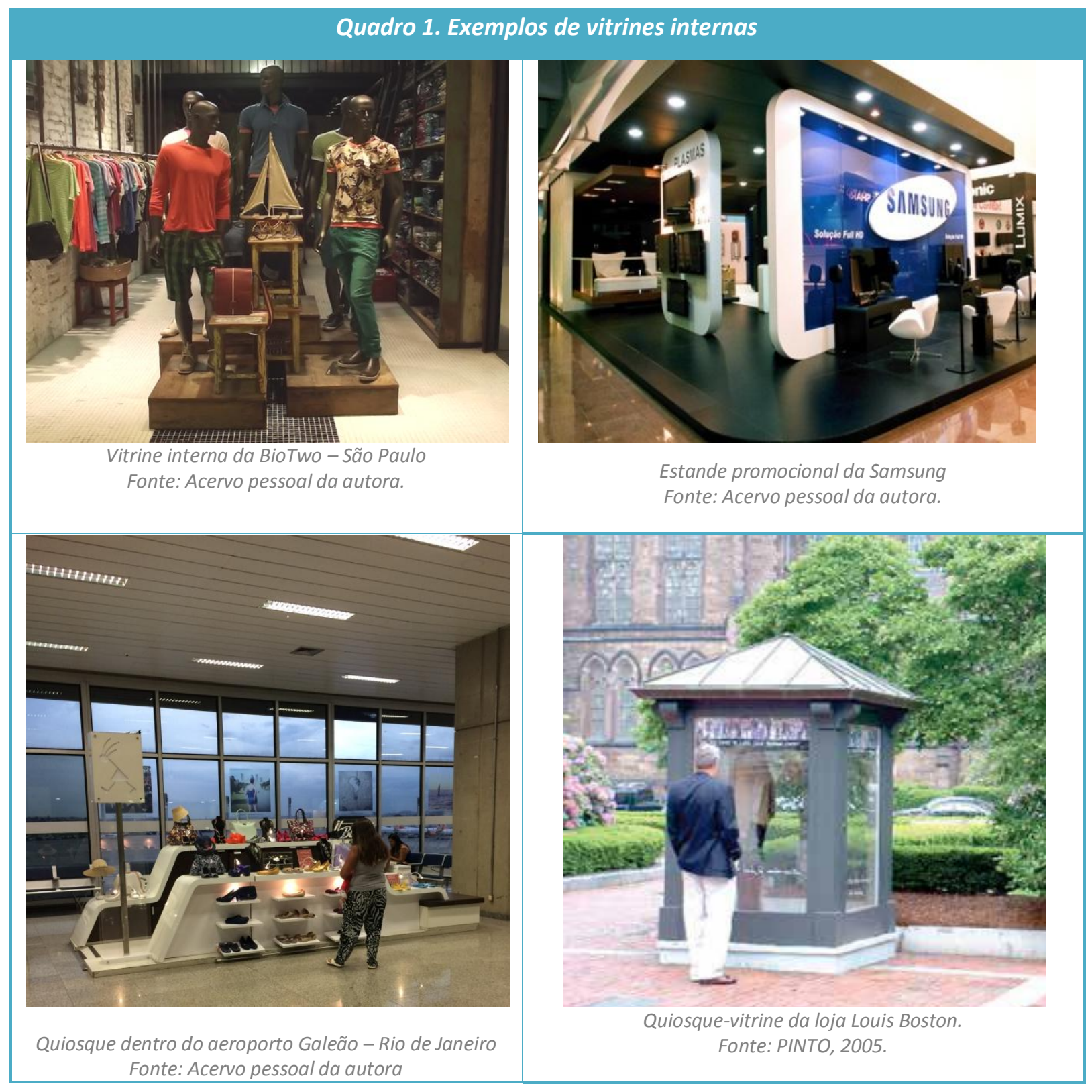


Além das ilhas, existem os nichos (Figura 38), que são vitrines pequenas de pouca profundidade, que podem ou não ter iluminação própria. Normalmente se localizam em paredes de corredores e são utilizados para dar destaque a certos produtos.

Figura 38. Nichos como forma de vitrine para expor tênis Fonte:http://fixturescloseup.c om/2015/02/26/mix-paintto-match-your-merchandise/

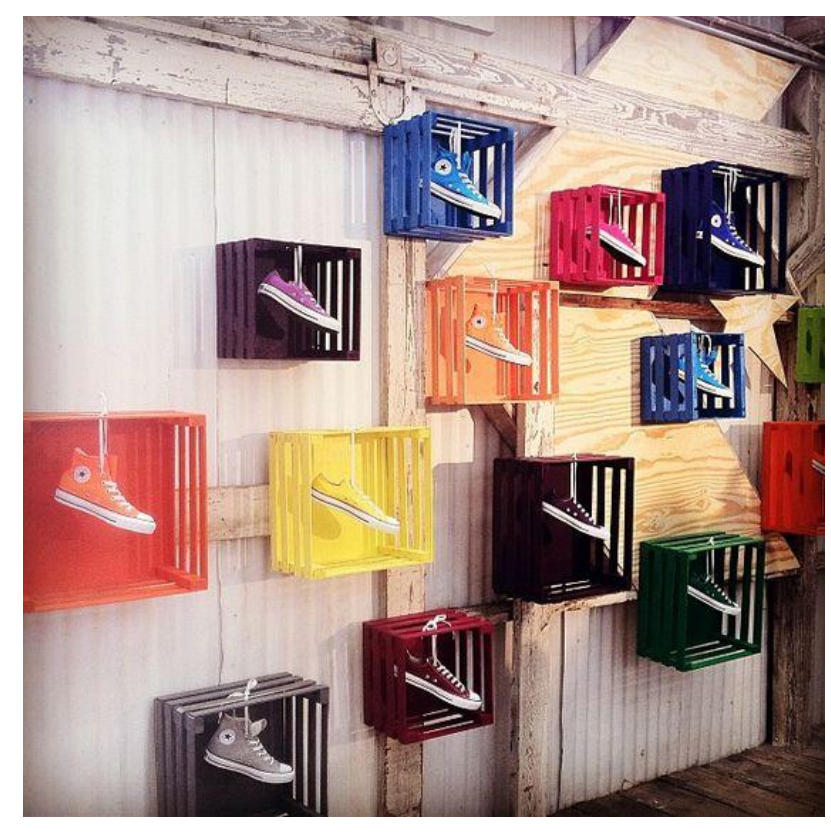

Outro tipo de vitrine interna é o balcão (Figura 39), também denominado de show-case. Este tipo de balcão tem normalmente um metro de altura, funcionando para expor produtos pequenos e podendo servir de balcão de atendimento.

Figura 39. Vitrine tipo balcão na loja Vivara do Shopping Iguatemi Fonte: Acervo pessoal da autora.

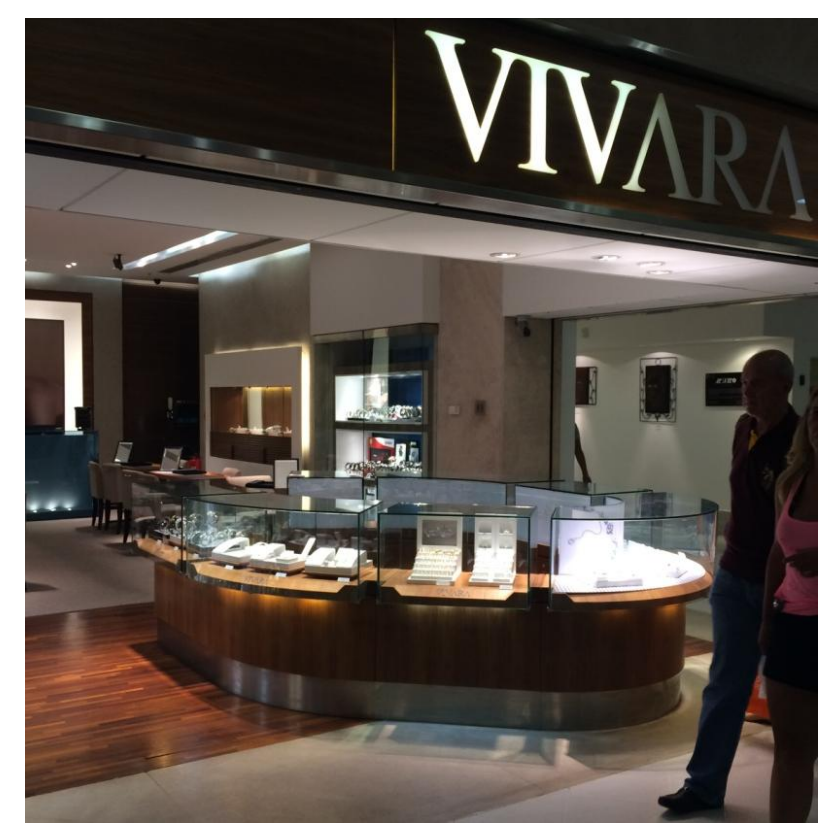


E por último, tem-se as gôndolas (Figura 40) que é um tipo de vitrine usada mais frequentemente em supermercados, farmácias, lojas de departamento e conveniência. Podem ser móveis ou fixas, com possibilidade de utilização em ambos os lados, o que permite uma maior visibilidade do produto. Em geral, as pontas das gôndolas são usadas para expor produtos em promoção ou lançamento, pois pelo maior destaque, acaba trazendo maior visibilidade em relação ao resto da gôndola.

Figura 40. Gôndolas da loja Extra de Fortaleza Fonte: Acervo pessoal da autora

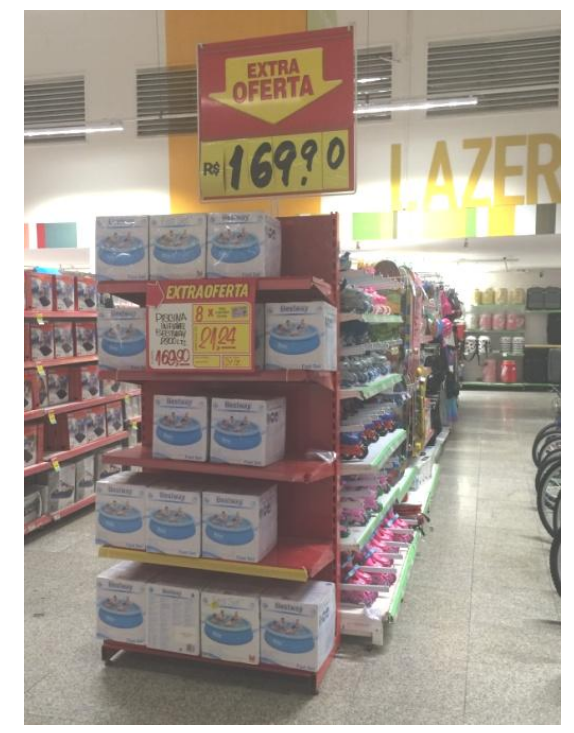

\subsection{CLASSIFICAÇÕES DE VITRINE}

A função da vitrine é determinante na escolha de produtos que comporão este espaço. Isso porque, a maneira como ocorre a divulgação destes produtos deve estar relacionada aos objetivos aos quais a vitrine se propõe, ajudando a reforçar os signos transmitidos por esta.

Segundo Lourenço e Sam (2011) é possível classificar as vitrines em relação a sua estética, às mensagens veiculadas nela e às funções que pode desempenhar (Tabela 3). Uma mesma vitrine pode ser composta por mais de uma classificação, ou seja, a vitrine pode, por exemplo, ser popular (classificação relativa à estética) e ao mesmo tempo ter uma mensagem comemorativa. 
Tabela 3. Classificações de vitrine

\begin{tabular}{|c|c|c|}
\hline \multirow[t]{7}{*}{ Quanto à estética } & \multirow{3}{*}{ Expositiva } & Popular \\
\hline & & Prestígio \\
\hline & & Clean \\
\hline & \multirow{4}{*}{ Figurativa } & Cenário \\
\hline & & Cenográfica \\
\hline & & Conceitual \\
\hline & & Impacto \\
\hline \multirow[t]{4}{*}{ Quanto à mensagem } & \multicolumn{2}{|r|}{ Publicitária } \\
\hline & \multicolumn{2}{|r|}{ Oportunidade } \\
\hline & \multicolumn{2}{|r|}{ Comemorativa } \\
\hline & \multicolumn{2}{|r|}{ Institucional } \\
\hline \multirow[t]{3}{*}{ Quanto à função } & \multicolumn{2}{|r|}{ Informativa } \\
\hline & \multicolumn{2}{|r|}{ Social } \\
\hline & \multicolumn{2}{|r|}{ Emotiva } \\
\hline
\end{tabular}

\subsubsection{QUANTO À ESTÉTICA}

No que refere-se a classificação da vitrine segundo a estética adotada, estas podem ser expositivas e figurativas.

As expositivas tem o foco no próprio produto, realçando suas qualidades e atrativos, através do uso ou não de expositores e material promocional, que terão o objetivo de valorizá-lo ao máximo.

São vitrines do cotidiano, comuns em lojas de centros comerciais e shoppings destinados a um consumidor menos exigente. Pode até utilizar técnicas de composição, mas sem uma decoração direcionada a um tema.

A vitrine expositiva subdivide-se em vitrine popular, de prestígio e clean.

As populares estão atreladas a lojas populares, que costumam trabalhar na vitrine com um grande volume de produtos (Figura 41), sem muitas vezes fazer uso de uma organização composicional racional. Normamente este tipo de vitrine está localizada em lojas que não possuem uma preocupação 
com o merchandising visual e nem ao menos possuem um projeto arquitetônico direcionado para o comércio, adaptando muitas vezes espaços para este uso.

Figura 41.

Vitrine popular, onde é possivel ver o excesso de produtos expostos. Fonte: Acervo pessoal da autora.

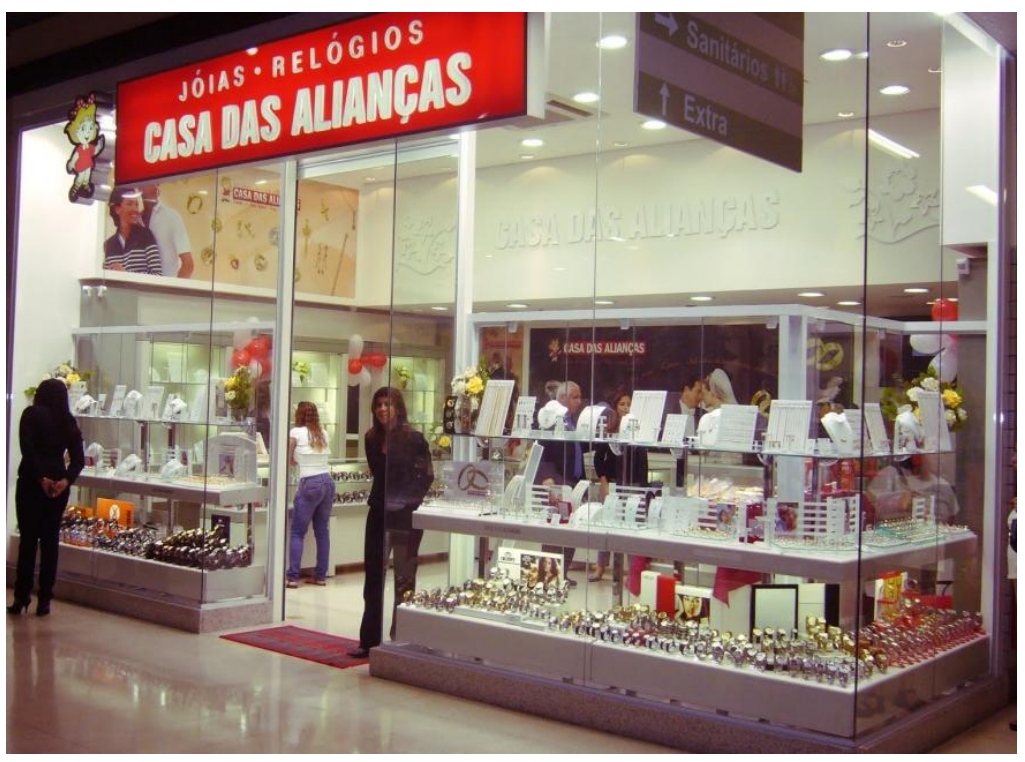

Este tipo de vitrine popular normalmente atrai um público que tem preferência por produtos mais baratos. Desta forma, a loja pode utilizar da estratégia da exposição excessiva de produtos para transmitir a impressão que seus produtos são mais baratos que na concorrência, mesmo que estes não sejam. A variedade e quantidade de produtos expostos, em detrimento de valores estéticos e artísticos, é uma variante que o mercado varejista popular tem, por crença, ser fundamental para aumentar o número de vendas, talvez por interferências históricas dos grandes mercados (Figura 42).

Figura 42. Vitrine de uma loja em Dubai, 2015. Fonte: Acervo pessoal da autora.

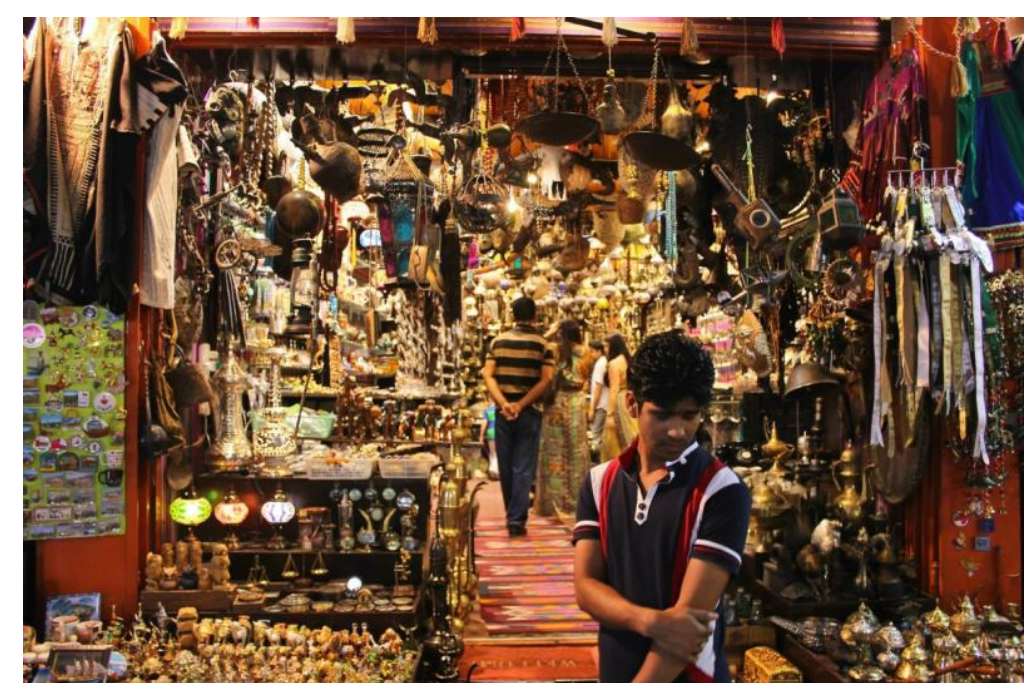


Além da vitrine exposita popular, tem-se a vitrine de prestígio, que busca prestigiar uma linha de produtos ou marca da loja. Pode ser uma linha de uma única marca ou uma linha de produtos de várias marcas selecionadas de um mesmo segmento.

Normalmente este tipo de vitrine está voltada a consumidores de alto padrão, onde a mensagem transmitida tem fator determinante na conceituação do produto, insinuando características específicas como durabilidade e qualidade.

E por fim, dentro da categoria exposita, tem-se a vitrine clean (Figura 43), onde os elementos decorativos são utilizados de maneira mínima possível, para que só o produto seja valorizado. Comum a lojas que comercializam poucas peças e com caráter exclusivo, estas vitrines normalmente possuem poucos produtos, o que agrega o conceito de individualidade.

Figura 43. Vitrine clean da loja Céline

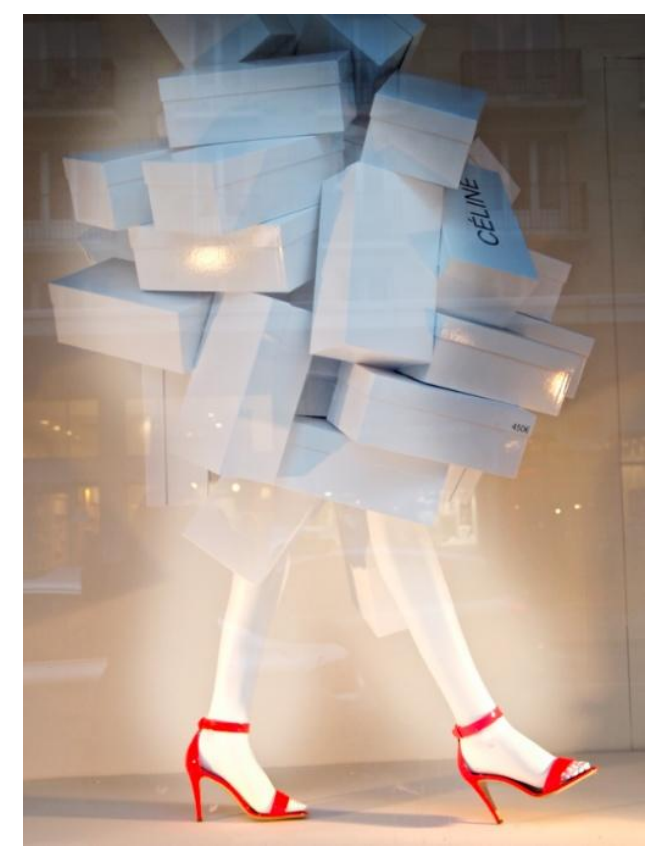

Existe ainda dentro da classificação quanto à estética adotada, das vitrines figurativas, que são as que fazem uso de elementos decorativos no intuito de valorizar os produtos expostos com o objetivo de sensibilizar e criar um vínculo emocional com o consumidor. A decoração surge para reforçar o conceito da vitrine, da loja, da marca e/ou do produto. 
A vitrine figurativa geralmente está relacionada a um tema, datas comemorativas ou pode simplesmente ser o principal elemento norteador do projeto da vitrine, integrando o produto ao cenário criado.

Desta forma, muitas são as possibilidades de uma vitrine figurativa. Para melhor compreensão, estas estão subdivididas em cenário, cenográfica, conceitual, cinética e de impacto.

As vitrines figurativas de cenário (Figura 44) buscam retratar um espaço específico, podendo passar conceitos, atitudes, estilos e características. Grande parte das vezes é dramática e cria um clima abusando de luzes cênicas e objetos decorativos.

Figura 44. Vitrine cenário da loja Dolce \& Gabbana (Milão) onde é retratado uma cena de um salão de beleza

Fonte:

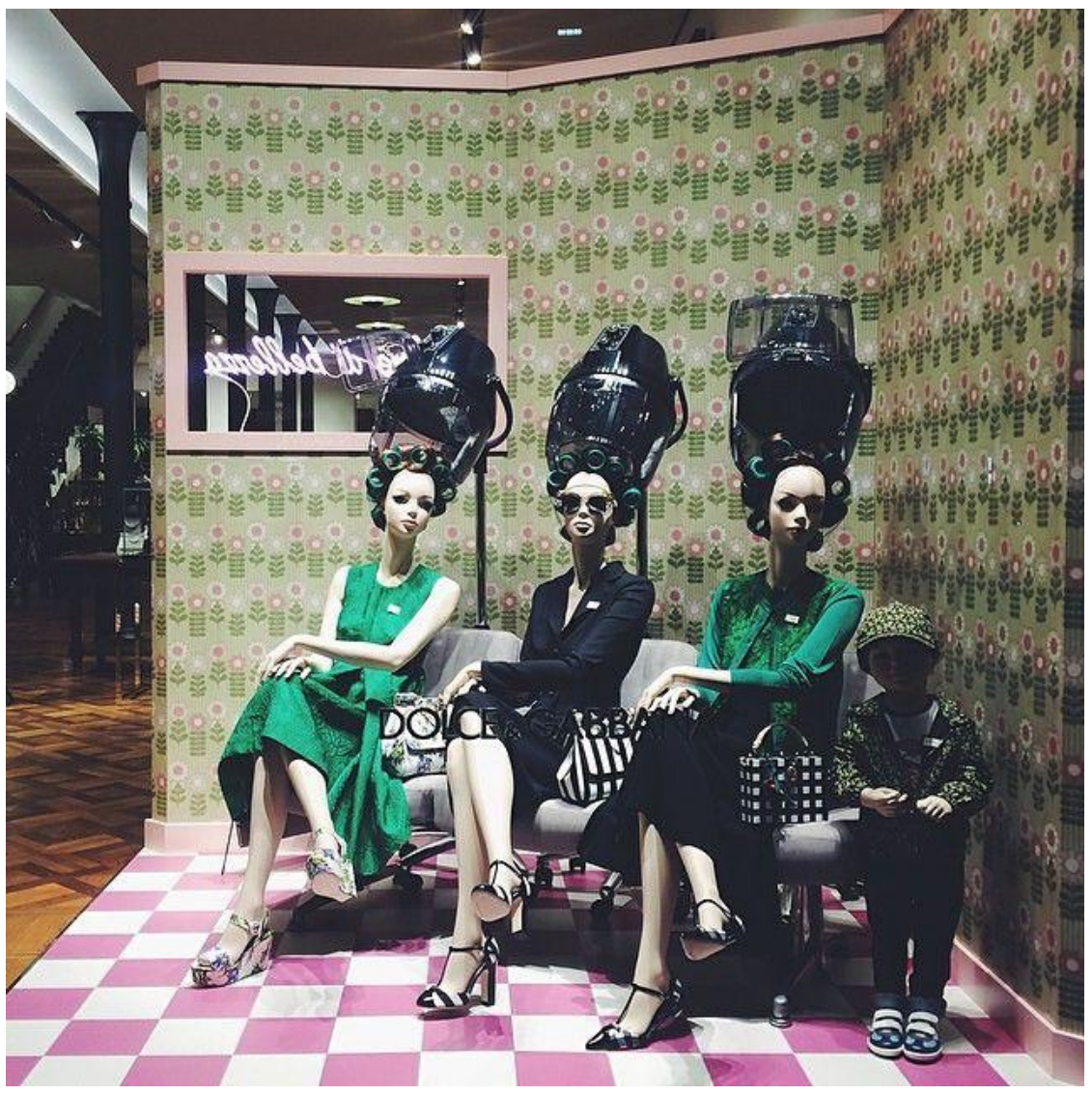

Já as vitrines figurativas cenográficas (Figura 45) utilizam normalmente um tema, uma história, para divulgar um produto e não retratam fielmente um ambiente, mas apenas insinua símbolos que remetem ao tema e/ou espaço a ser projetado na mente dos consumidores. 
Figura 45. Vitrine cenográfica da Loja tiffany \& CO - Nova lorque, 2013.

Fonte:

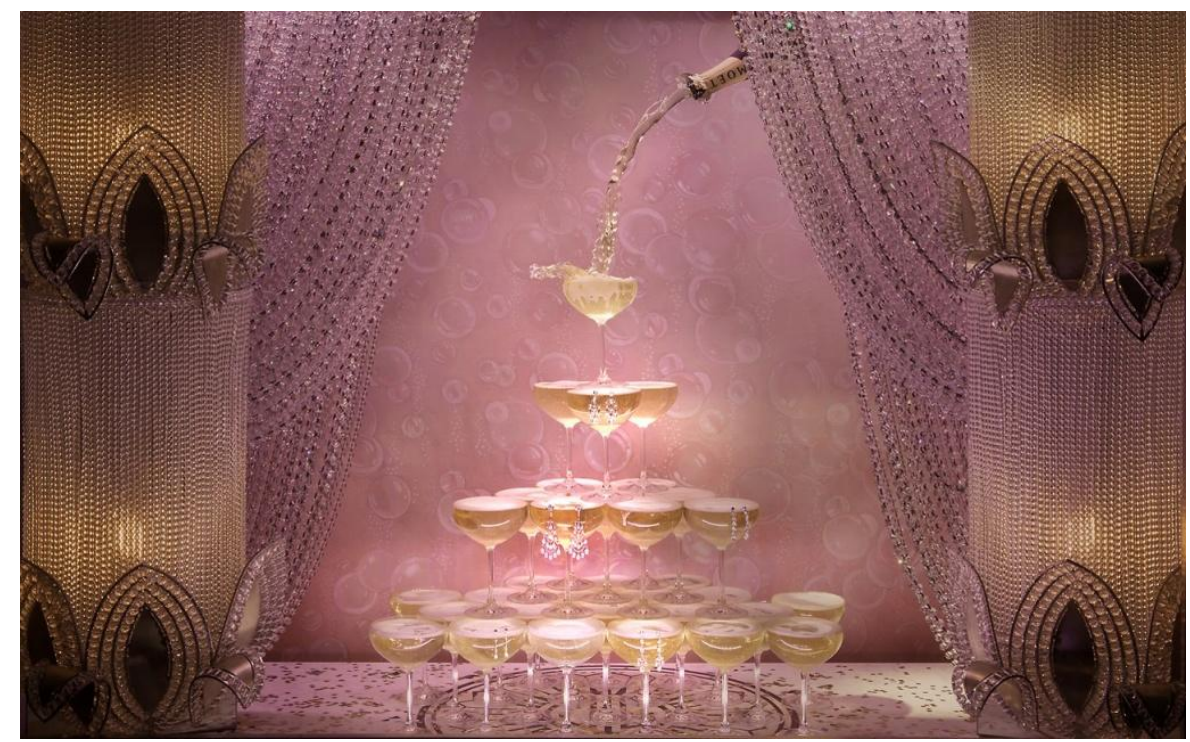

Há ainda as vitrines conceituais (Figura 46), que não necessariamente tem o objetivo de vender um produto, mas sim de transmitir um conceito, que pode estar implícito tanto no elemento decorativo, quanto nas imagens, no comportamento e na atitude representados pelos manequins, nos objetos decorativos associados a marca ou ainda na própria arquitetura do ambiente comercial. Este tipo de vitrine, normalmente é mais utilizada quando se já tem uma marca consolidada na mente dos consumidores.

Figura 46. Vitrine conceitual da Chanel em Paris (2011)

Fonte:

http://cibilbao.com/2011/12/ 07/escaparates-de-navidad2011-hoy-viajamos-a-paris-y-

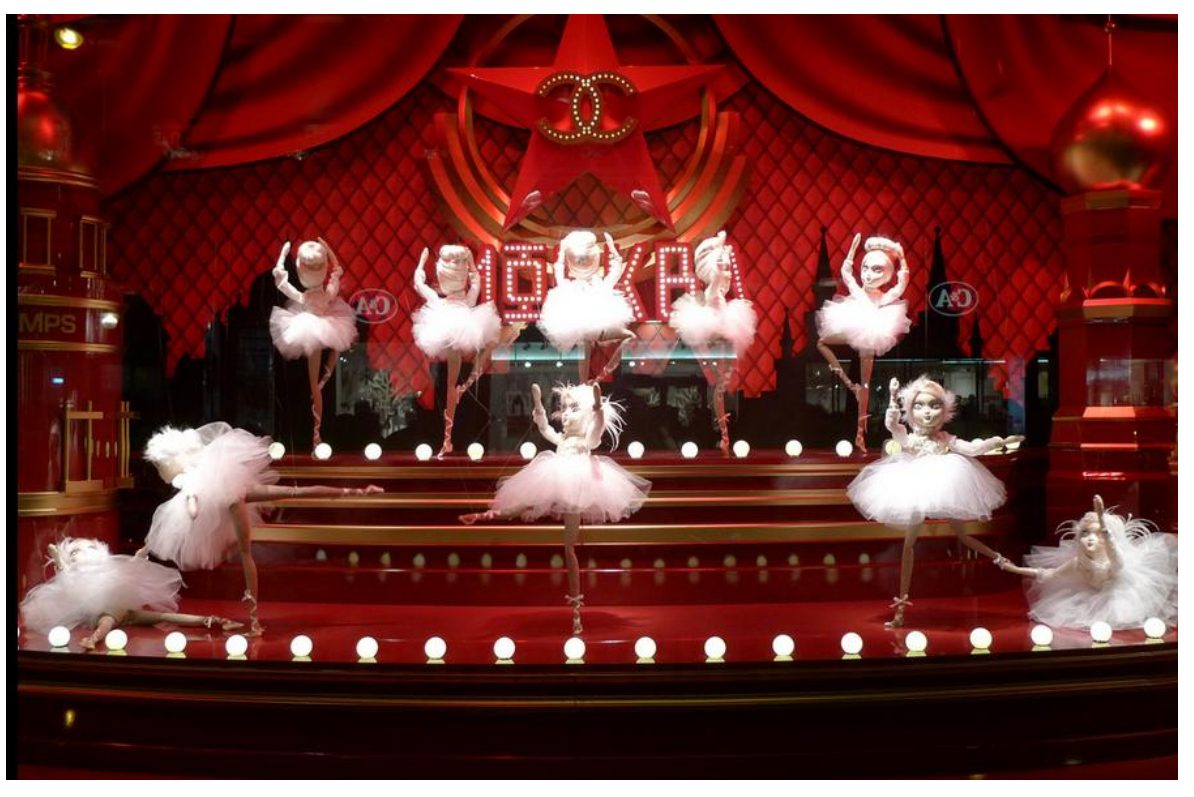

Outra categoria das vitrines figurativas é a cinética. Nela, a presença de algum elemento que possua movimento, ou que induza o consumidor a isso, é explorando na vitrine. A experiência visual do movimento induzido 
por um artifício está sujeita a fatores sinestésicos, que tornam possíveis a sensação do movimento, mesmo que o elemento não esteja realmente se mexendo.

Existem vitrines cinéticas, onde o movimento pode ocorrer realmente através de elementos animados, displays giratórios, recursos com projetores, etc. Ou ainda uma junção do movimento induzido com o movimento real. Foi o que ocorreu em 2009, quando o designer japonês Tokujin Yoshioka criou uma instalação na vitrine da marca Hermès em Tóquio (Figura 47). Na vitrine estava projetado um filme de uma mulher soprando um lenço pendurado (Figura 48), que se movimentava conforme o vídeo, criando a ilusão que realmente o vento gerado para movimentá-lo era proveniente do sopro da mulher.

Figura 47. Vitrine da loja Hermès com a instalação do designer

Tokujin Yoshioka Fonte: www.iainclaridge.co.uk

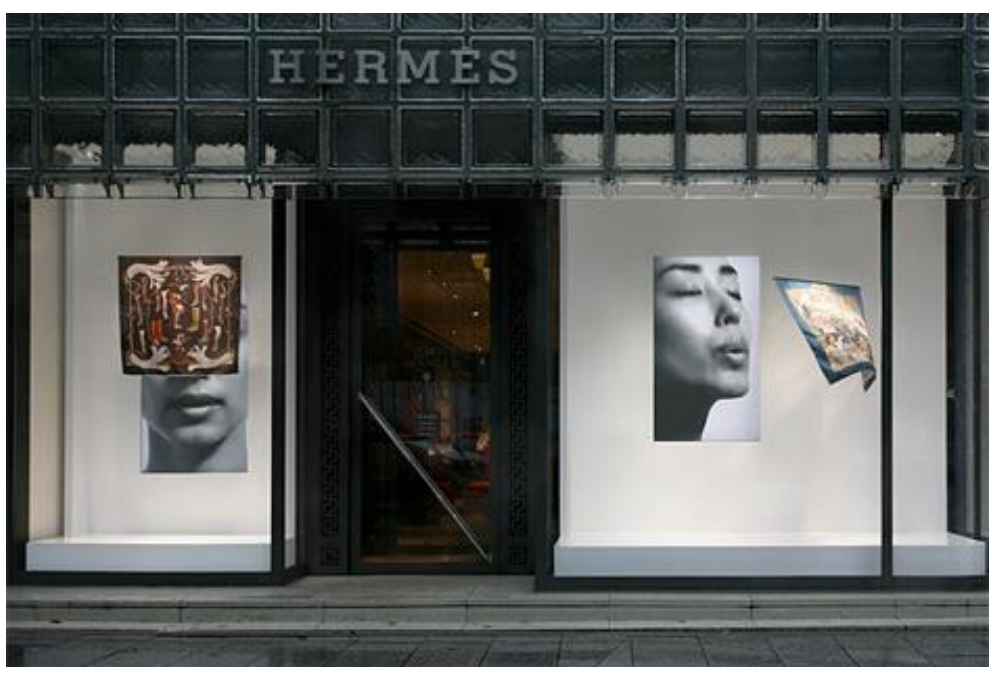

Figura 48. Sequência dos movimentos do vídeo da instalação de Tokujin Yoshioka Fonte: www.iainclaridge.co.uk

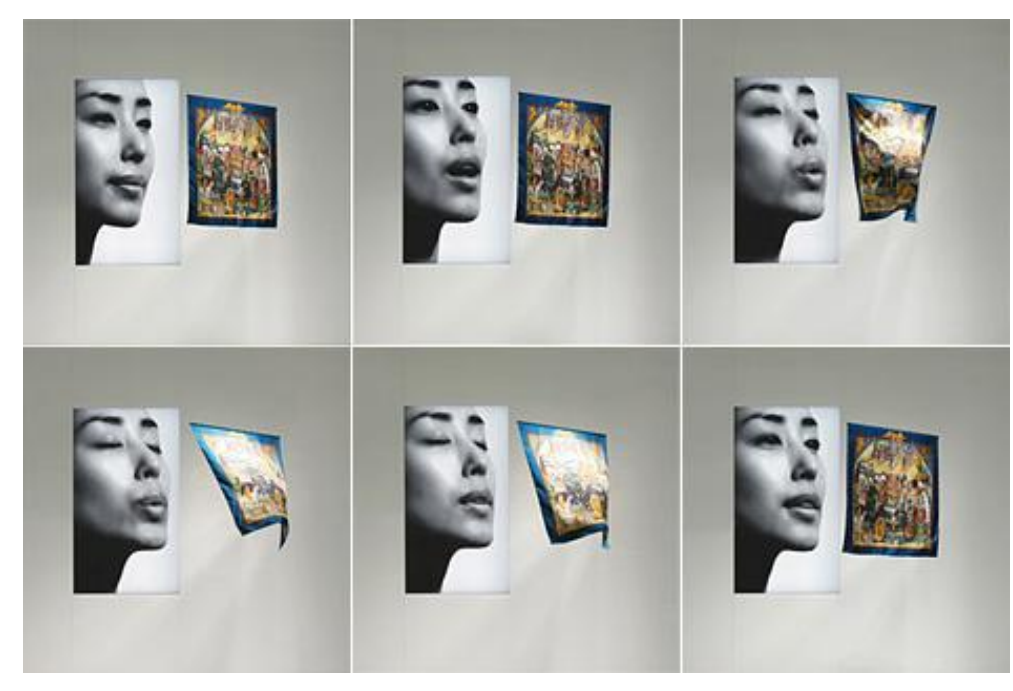


A última categoria de vitrine figurativa é a de impacto. Como o próprio nome já sugere, o obejtivo deste tipo de vitrine é causar um impacto visual ou emocional, gerado por qualquer recurso pertinente ao design visual. Isso inclui desde objetos decorativos, cores, formas, dimensões e iluminação que interfira no comportamento do consumidor, atraindo sua atenção para a vitrine.

Esta atração por ocorrer devido à utilização de uma escala maior do objeto real (Quadro 2), a elementos decorativos inusitados, que fogem de um padrão, tanto o próprio elemento em si, quanto na sua forma de exposição. Ou ainda ao uso de cores no intuito de criar um apelo visual e até mesmo no uso de um tema geral para composição da vitrine, podem criar um impacto no consumidor.

\section{Quadro 2. Vitrines com objetos em escala alterada}

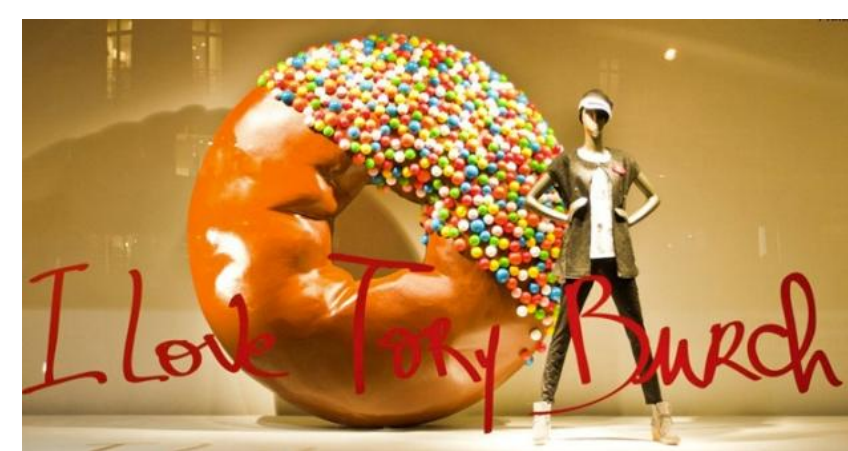

Donut gigante da vitrine da loja Printemps - Paris, 2010. Fonte: http://retaildesignblog.net

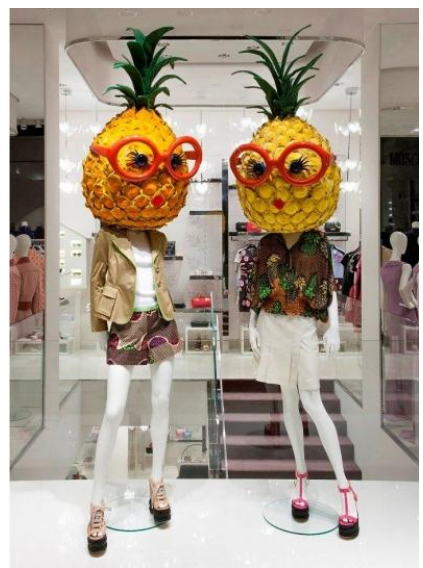

Manequins com cabeça de abacaxi na vitrine da loja Moschino Milão, 2013

Fonte: https://br.pinterest.com/pin/132363676524570796

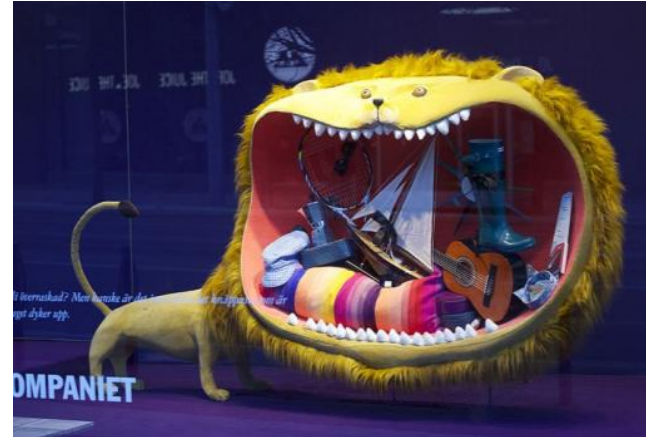

Leão com cabeça gigante de uma vitrine de Estocolmo Fonte: http://mi3ch.livejournal.com/2299020.htm/

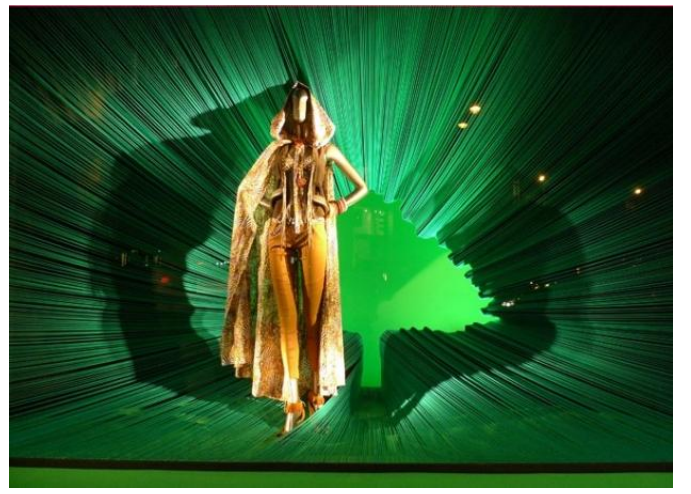

Iluminação cênica conciliada com o uso de um fundo de cor predominante verde na vitrine da loja Printemps - Paris, 2011 Fonte:

https://br.pinterest.com/pin/268386459016822709 


\subsubsection{QUANTO À MENSAGEM}

Cada vitrine carrega consigo uma mensagem contida em cada elemento que a compõe. Pode ser mensagens que transmitam alguma tendência, um conceito, um direcionamento de público, entre outros. Sendo a vitrine, então, uma forma de mídia que veicula uma informação e transmite uma visão a partir de uma montagem discursiva, fará parte desta relação o diálogo visual entre uma dupla de agentes importantes e de existência concomitante: emissor e o receptor, no caso a loja e o consumidor.

Neste quesito podemos classificar as vitrines em: mensagem publicitária, de oportunidade, comemorativa e institucional.

A vitrine com mensagem publicitária (Figura 49), geralmente integra a uma campanha publicitária para a divulgação do lançamento de um novo produto ou uma nova linha de produtos. Neste sentido, o restante da loja se integra a este tipo de vitrine, mantendo a mesma comunicação no interior do estabelecimento.

Uma estratégia adotada por vitrines publicitárias é a repetição dos produtos de lançamento, sendo apresentados em grande quantidade para que seja reforçada na mente do observador esta novidade. Assim, a vitrine indica que neste momento, o mais interessante para o cliente é o que está sendo lançado, já que os outros tipos de produtos se encontram no interior da loja.

Figura 49.

Vitrine publicitária para o lançamento do perfume Miss Dior em 2012

Fonte:

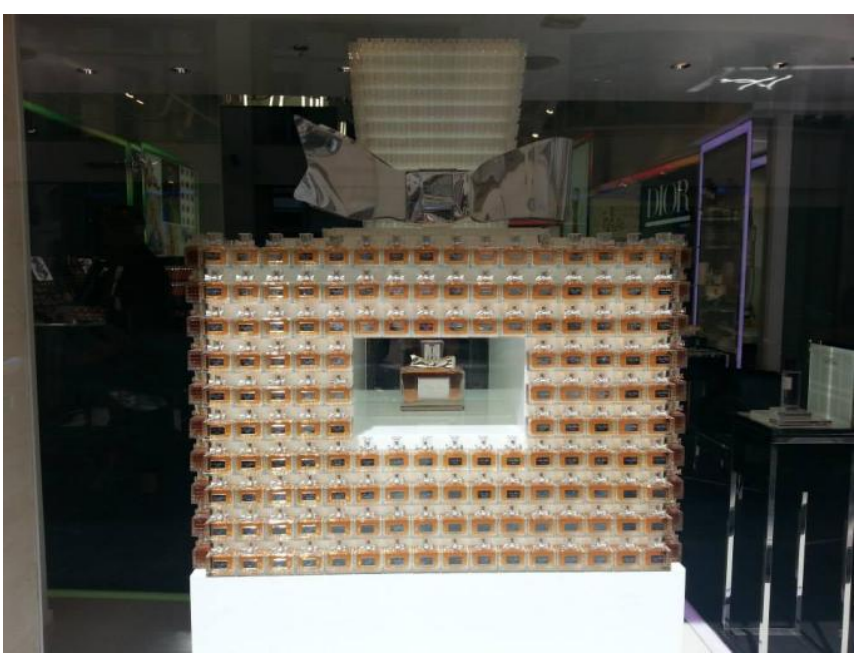


Há ainda as vitrines que trazem a mensagem de oportunidade. São realizadas em épocas de pouco movimento para estimular as vendas e sinalizam promoções e vendas especiais. Normalmente ocorrem no fim/início de uma estação para que se liquidem os produtos que estão na loja e, assim, seja possível renovar o estoque.

Como estratégia para este tipo de vitrine são feitos descontos especiais ou qualquer outro tipo de oportunidade que ajude a aquecer o movimento.

É comum neste tipo de vitrine, as lojas não exporem produtos na vitrine (Figura 50), indicando ao consumidor que a liquidação gerou efeitos tão positivos que o resultado é a falta de produtos até na vitrine. No caso de vitrines com produtos, é frequente a utilização de banner e adesivos com forte impacto visual. Segundo Lourenço e Sam (2011):

Embora seja uma comunicação de impacto pela dimensão e proporção da mensagem, quando o adesivo fecha totalmente a extensão do vidro da vitrina, perdemos a visão do que é prioridade, ou seja, as peculiaridades do produto, seus detalhes, cor, modelos. Também pode impedir o acesso de consumidores que se sentirão inseguros $e$ inibidos para entrar na loja, $e$ mesmo a captação e a conquista de novos clientes. Assim, esse tipo de vitrina é mais indicada para clientes que conheçam o perfil da loja e seus produtos. (LOURENÇO E SAM, 2011, P. 89)

Figura 50.

Vitrine da loja Richards do Shopping Iguatemi

Florianópolis.

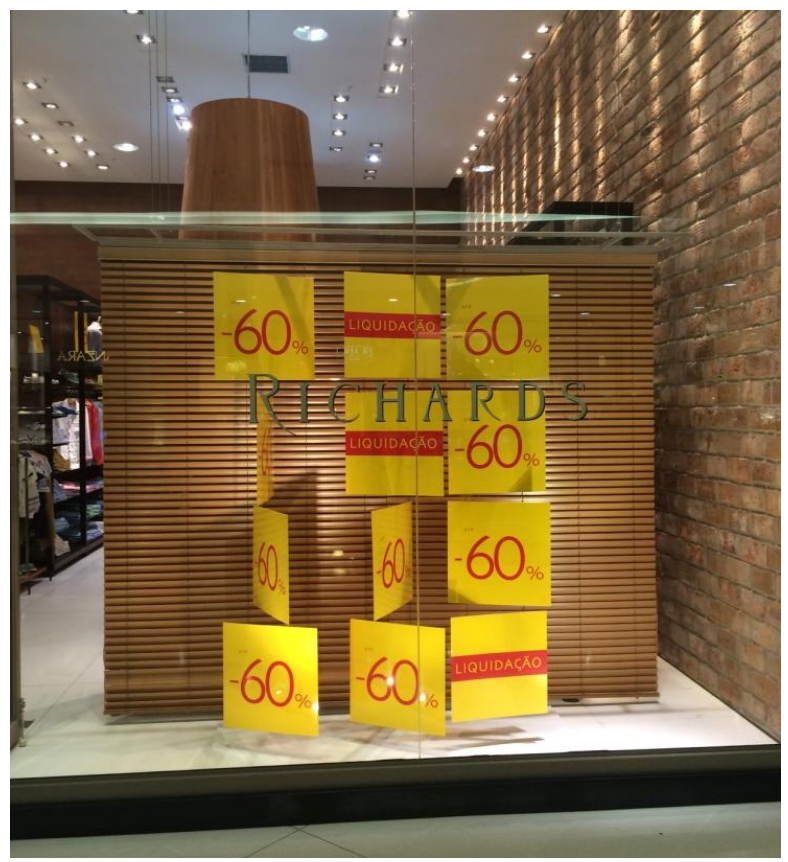


Já as vitrines comemorativas retratam datas festivas comuns à sociedade, como por exemplo, natal, dias das mães, dos pais (Figura 51), dos namorados (Figura 52), das crianças e páscoa. Estas datas comemorativas já estão definidas no calendário anual, que as lojas podem ter acesso em associações comerciais, como o Sebrae - Serviço Brasileiro de Apoio às Micro e Pequenas Empresas. As vitrines com datas especiais são comemoradas conforme o ramo de atividade. Uma loja exclusivamente voltada para o público masculino não terá vitrines comemorativas do dia das mães, o mesmo ocorrerá com as lojas femininas no dia dos pais ou lojas infantis no Dia dos Namorados, por exemplo.

Figura 51. Vitrine comemorativa do dia dos pais na Renner, 2011. Fonte: http://www.colunistas.com/

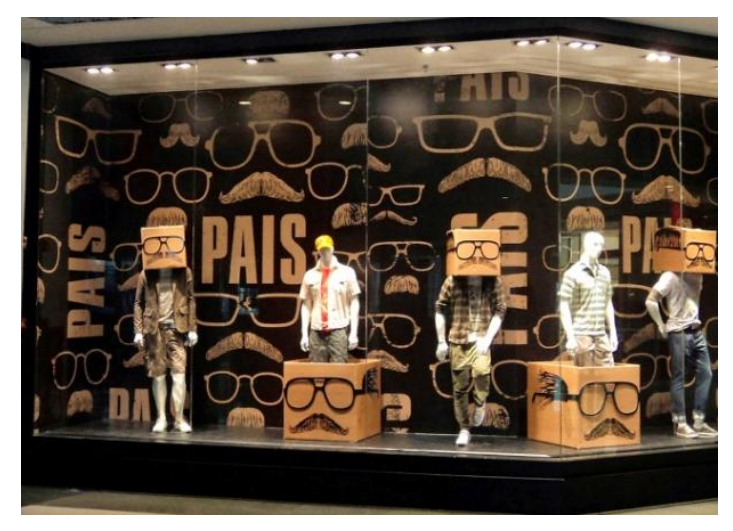

Figura 52. Vitrine da loja Pucker Up para o dia dos namorados Fonte:

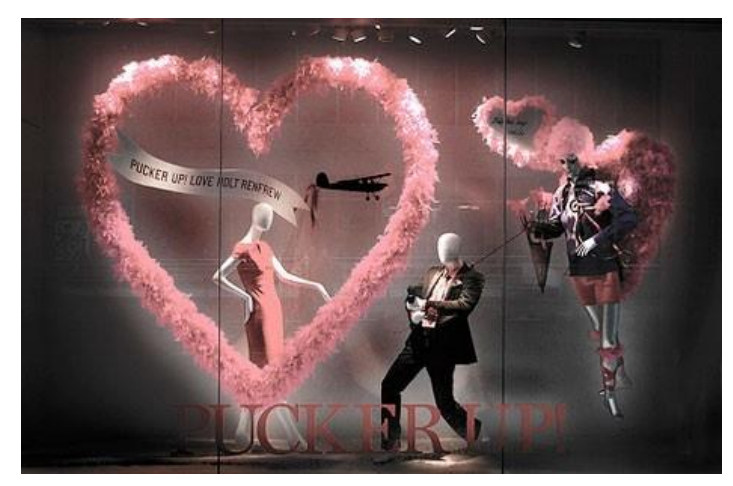

Além disso, as vitrines comemorativas podem retratar festas locais, como o aniversário da cidade, chegada de uma estação - primavera, verão, outono e inverno (Figura 53), algum evento importante, como olimpíadas (Figura 54), copa do mundo, e etc. 
Figura 53.

Vitrine comemorativa do inverno da loja Anthropologie, 2009.

Fonte: http://gottstyle.net/portfoli

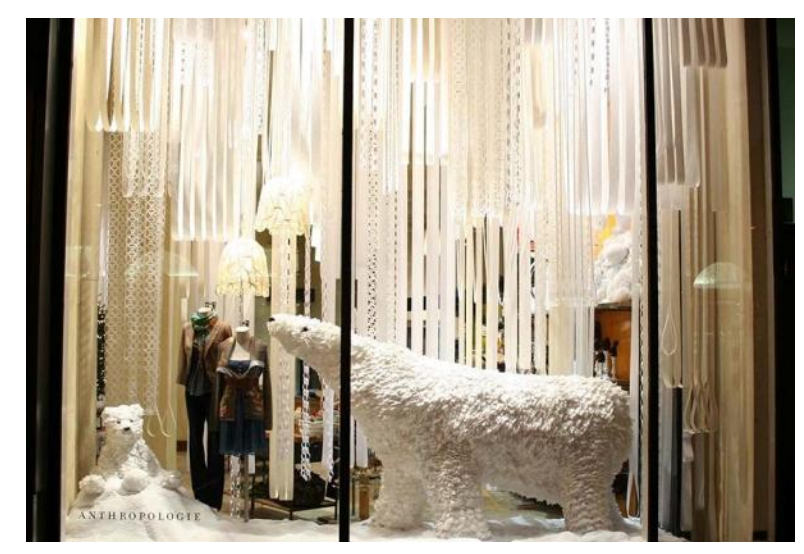

Figura 54. Vitrine comemorativa das olimpíadas da loja Forever

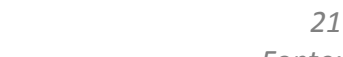

http://www.boymeetsfashi on.com

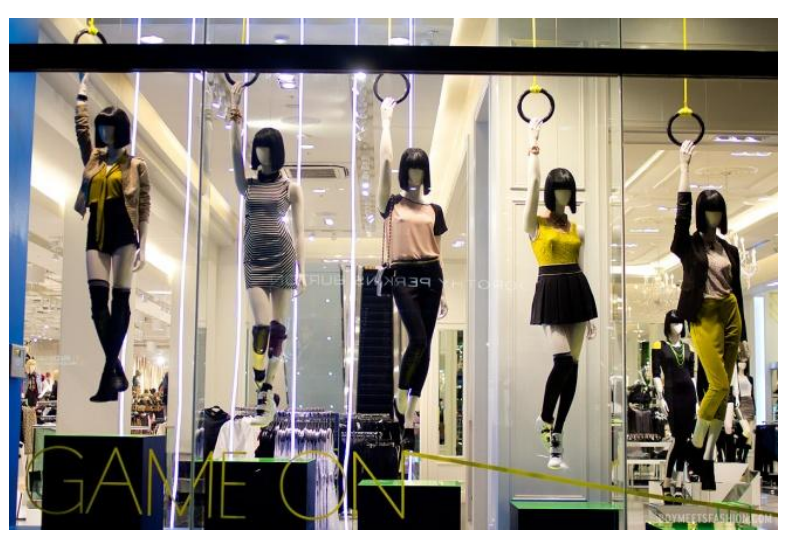

A última classificação é a vitrine com mensagem institucional, onde ocorre a transmissão do conceito da marca e sua imagem em detrimento do produto. Nestas vitrines são explorados normalmente o logo da empresa ou qualquer outro símbolo que represente a instituição. Sua utilização serve para destacar a marca do produto que é oferecido neste estabelecimento. Geralmente é direcionada a um consumidor de padrão mais elevado, pois este tipo de vitrine é na maior parte dos casos utilizada por marcas já consolidadas, que possuem um conceito de status vinculado a si.

Ocorre também em lojas de departamento de alto padrão, que trabalham com várias marcas consideradas importantes e precisam divulgar os produtos que vende. Desta forma, fazem uso da vitrine institucional, trocando periodicamente suas vitrines conforme as marcas parceiras, fazendo com que todas as marcas fiquem em evidência por um determinado período de tempo na loja.

Pode-se observar na Figura 55, um exemplo de vitrine institucional destacando uma marca específica, no caso a Chanel, comercializada na loja 
Printemps em Paris. Constituído por duas letras ' $C$ ' entrelaçadas - iniciais de Coco Chanel, o logotipo da Chanel possui destaque na composição da vitrine, assumindo papel articulador dos elementos, com grande impacto visual. Este logotipo foi projetado por Coco Chanel-se em 1925 e permanece inalterada desde então, sendo um dos logos mais simbólicos da indústria da moda.

Figura 55. Vitrine da Chanel na loja Printemps - Paris Fonte:

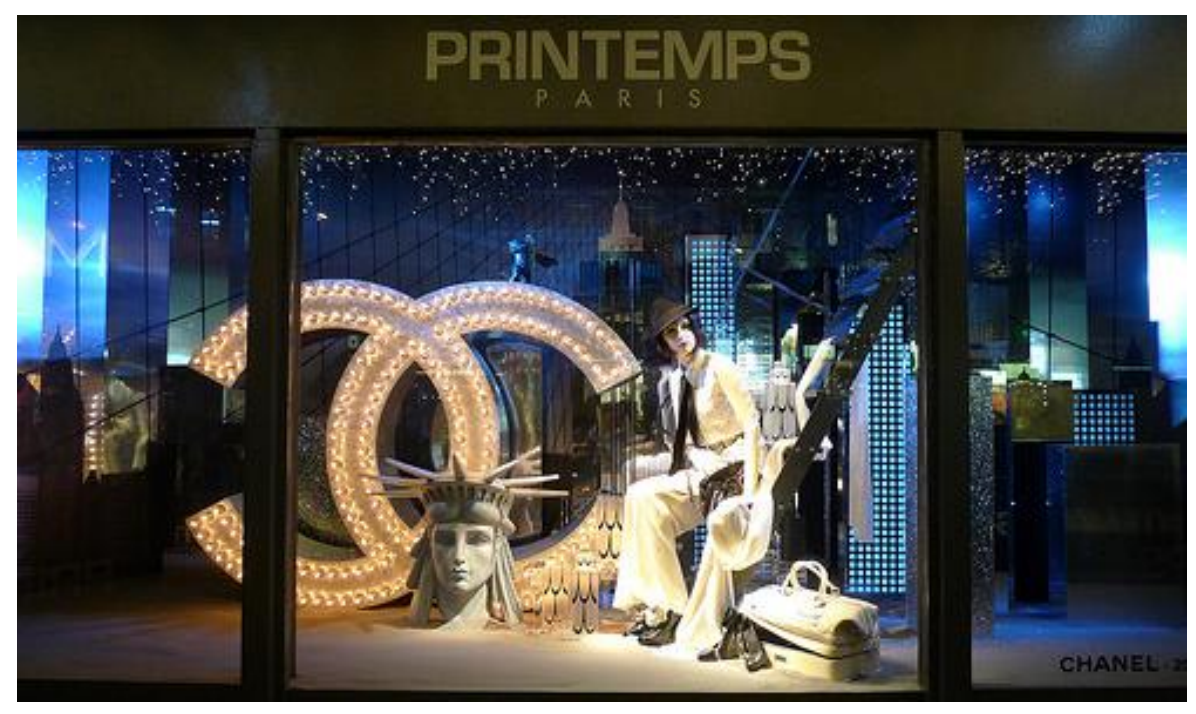

\subsubsection{QUANTO À FUNÇÃO}

As vitrines podem ainda ser classificadas de acordo com as diferentes funções que assumem. Tais funções podem ser projetadas tendo por base os objetivos e conceitos ligados a marca, ou marcas, comercializada na loja.

As funções podem ser informativas, quando se tem por objetivo transmitir de maneira objetiva e clara características de um produto exposto, como funcionalidade e tecnologia, a simples apresentação de um serviço oferecido ou ainda informações sobre o lançamento de algum objeto tecnológico. É possível neste tipo de vitrine informativa fazer uso de painéis de tendência, que permitam o consumidor ter informações que o ajudem a entender o panorama da moda, por exemplo.

As vitrines podem ainda ter função social, ao ter um enfoque na cultura e características de uma população/país, ao vincular mensagens ligadas ao 
bem-estar e saúde, à educação, à conscientização social, racial, de gênero e etc. O papel social da vitrine também pode ser exercido ao se buscar elementos de artesanato regionais.

A função social pode estar interligada de forma concomitante à função informativa e à emotiva. Esta última tem o objetivo de incitar no sujeito emoções, sensações e lembranças. A vitrine emotiva busca sensibilizar o consumidor, de maneira que o atraia para a compra, o que normalmente é feito pelas vitrines comemorativas que se utilizam de artifícios emocionais para despertar o desejo do consumo.

$\mathrm{Na}$ Figura 56 é possível ver as três funções numa mesma vitrine. Apresentada na loja Bergdorf Goodman, de Nova lorque, em celebração a abertura da exposição sobre a cultura Punk no museu Metropolitan. Esta vitrine é informativa, pois aborda conceitos da cultura punk, de forma que seu público possa refletir sobre este tema, além de informar ao observador sobre a exposição que ocorre no museu. Traz a questão social, pois veicula uma cultura específica de um movimento americano relevante. E por fim, possui função emotiva, pois desperta sensações ao observador, podendo trazer à tona lembranças e reações emotivas.

Figura 56. Vitrine da loja Bergdorf Goodman em Nova lorque (2013) sob o título "Punk Influence: Past, Present, Future" [Influência punk: passado, presente, futuro]

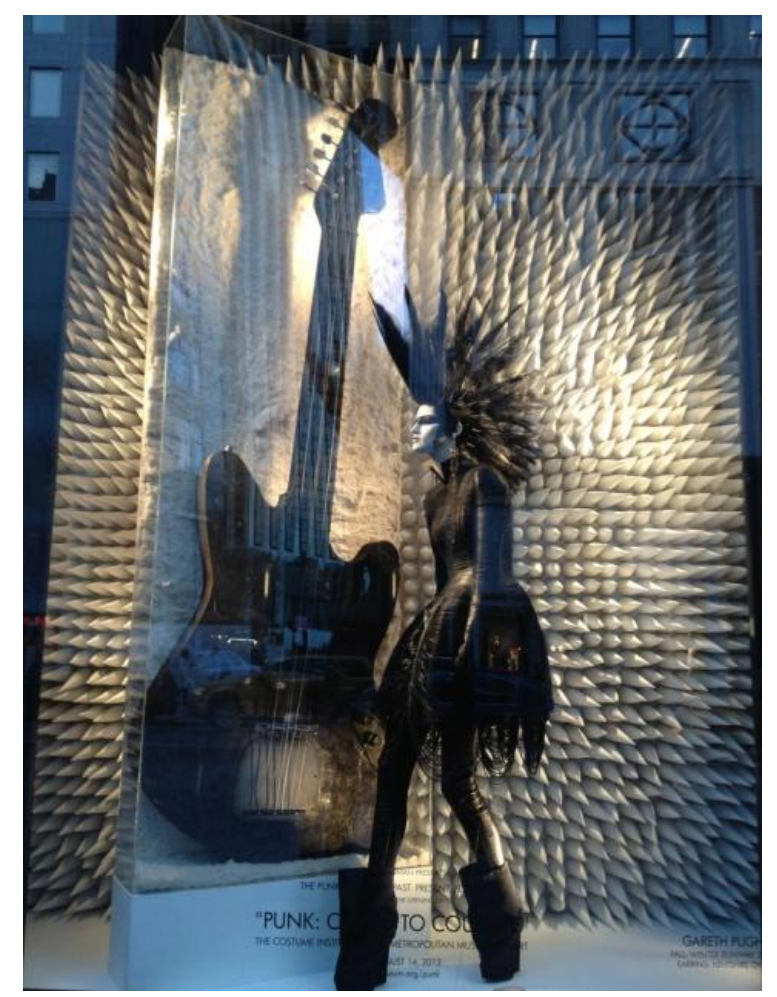




\section{Capítulo 4}

\section{Design Visual e}

\section{Fachadas Comerciais}

As fachadas comerciais, na sua imensa diversidade de formas, cores e estruturas, em conjunto com a arquitetura do edifício são uma imensa tela branca de múltiplas possibilidades para apropriação do design visual.

Adota-se neste trabalho, como definição de design visual, todas as diversas facetas existentes no design aplicadas na comunicação que ocorre através de canal visual para transmissão de mensagens, não se limitando ao suporte de determinada mídia envolvida, como ocorre com o design gráfico ou design digital (ARNHEIM, 1997; GARRET, 1975).

Enquanto caixa vazia, a vitrine não apresenta nenhum significado, porém quando é preenchida pelos diversos elementos arquitetônicos e de design visual, esta se torna uma manifestação de um discurso tridimensional, que pode ser decodificado. Esta leitura é possível:

No momento em que ela toma parte de uma estrutura arquitetônica de uma loja, ou de um stand, terá marcas indicadoras que determinarão modos de leitura que serão reforçados pelos elementos inseridos no seu discurso, e pela disposição para cima e para baixo, à direita ou à esquerda, ela firma a condição em que está instalada (DEMETRESCO, 2001, p. 36).

Muitas são as mensagens que se podem transmitir ao observador. Exclusividade, elegância, popularidade, simplicidade são alguns conceitos 
que podem ser explorados. O design visual aplicado nas fachadas comerciais surge para tornar mais eficaz a comunicação entre a marca e o consumidor. Além de otimizar a forma como ocorre a atração deste à loja, que por sua vez está ligado diretamente ao efeito visual criado para este espaço. Considerando o fato que a vitrine influencia o consumo, então podemos afirmar que este depende consequentemente da ordem visual estabelecida naquela.

Desta forma, o objetivo será apresentar abaixo as principais formas de aplicação do design visual em estabelecimentos comerciais varejistas através da composição de vitrine, exposição de produtos, iluminação, elementos decorativos e de apoio, identidade visual, entre outros.

\subsection{ARQUITETURA DAS LOJAS: NOVAS CATEGORIAS PARA O SÉCULO XXI}

Como visto no capítulo anterior, muitas foram as mudanças ocorridas nos espaços comerciais ao longo das últimas décadas. A arquitetura dos ambientes comercias tem-se reinventado, buscando uma aproximação com a cidade e tornando-se por vezes um marco na paisagem urbana.

Tendo em vista estas novas possibilidades, buscou-se agrupar em categorias as lojas com este novo perfil. Desta forma foram criadas as categorias: loja multifunção, com espaço semi-público, experiência, conceito e escultural.

\subsubsection{LOJA MULTIFUNÇÃO}

Tem feito parte da mudança do perfil dos estabelecimentos comerciais, a diversidade de serviços encontrados num mesmo espaço. Quase como uma resposta as múltiplas identidades assumidas pelo consumidor a partir dos desdobramentos da pós-modernidade. Cada vez mais as lojas tem se 
adaptado a esta nova realidade, tornando seus espaços mais versáteis, explorando ao máximo o caráter nômade, onde a arquitetura se renova enquanto função.

É uma nova forma de apresentar a arquitetura comercial, resignificando conceitos em consonância com a tentativa de se estabelecer um caráter nômade da construção. A arquitetura da loja tem deixado de ser rígida e começa a se flexibilizar as novas possibilidades.

Em São Paulo, um dos casos mais representativos é a loja Caos. Localizada desde 2011 no Baixo Augusta, a loja que é um misto de antiquário, brechó, bar e boate. Por fora, a fachada de grafites coloridos, assinada pelo grafiteiro Chivitz, já insere o observador na atmosfera que o aguarda dentro da loja (Figura 57). Uma profusão de imagens e cores caoticamente ordenadas transmite com exatidão a essência da loja.

Figura 57.

Fachada da loja Caos Fonte: Acervo pessoal da autora.

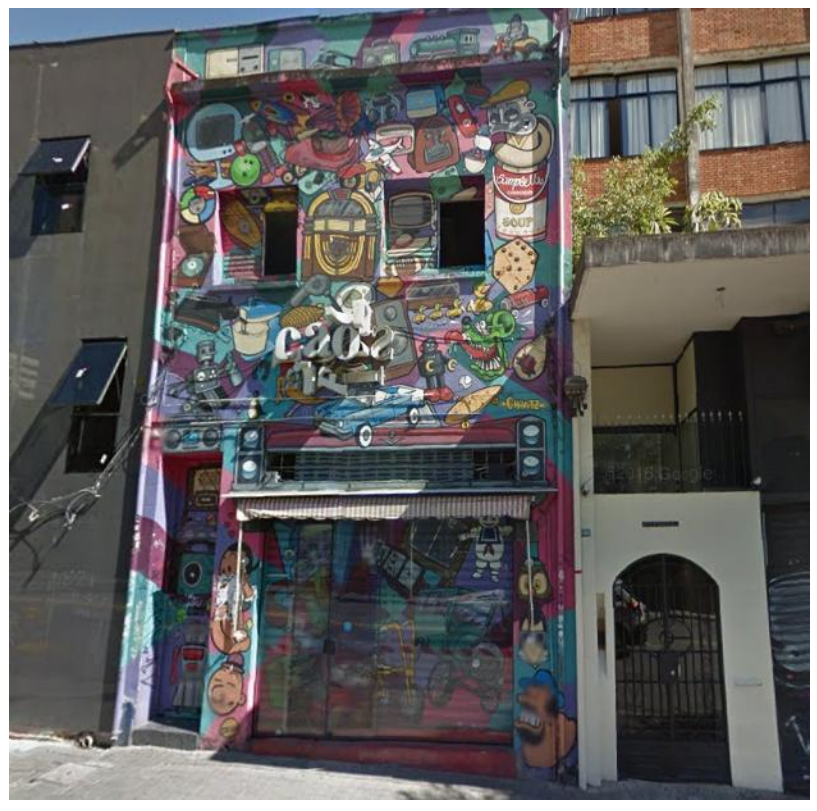

A comunicação na fachada do nome da loja é feita através de letras caixas, distribuídas de maneira desordenada (Figura 58), que reforça ainda mais a identidade da marca. 
Figura 58. Sinalização da marca da loja na fachada é feita por letras

caixa.

Fonte: Acervo pessoal da autora

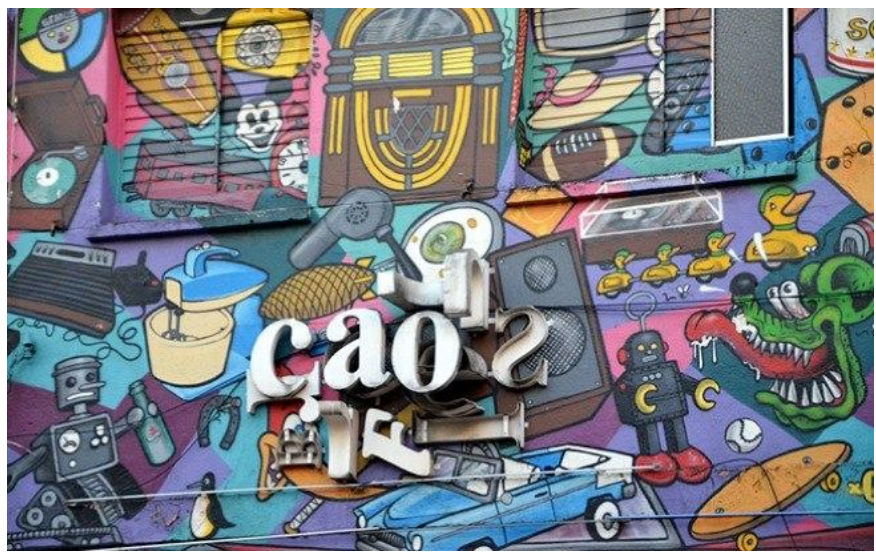

A noite a iluminação da fachada é feita através de lâmpadas de neon (Figura 59) que foram extremamente populares nas décadas de 1980/1990 e hoje reforçam na fachada o conceito de antiguidade, mas que, ao mesmo tempo, por ter caído nas graças das tribos amantes do retrô, retorna com força e traz com ele o conceito de criatividade. E segundo reportagem na folha online ${ }^{8}$ (2011): "O neon virou 'hype ${ }^{9}$. É procurado por gente criativa e moderna."

Figura 59. Fachada da loja Caos vista a noite, detalhe para os luminosos de neon Fonte: Acervo pessoal da

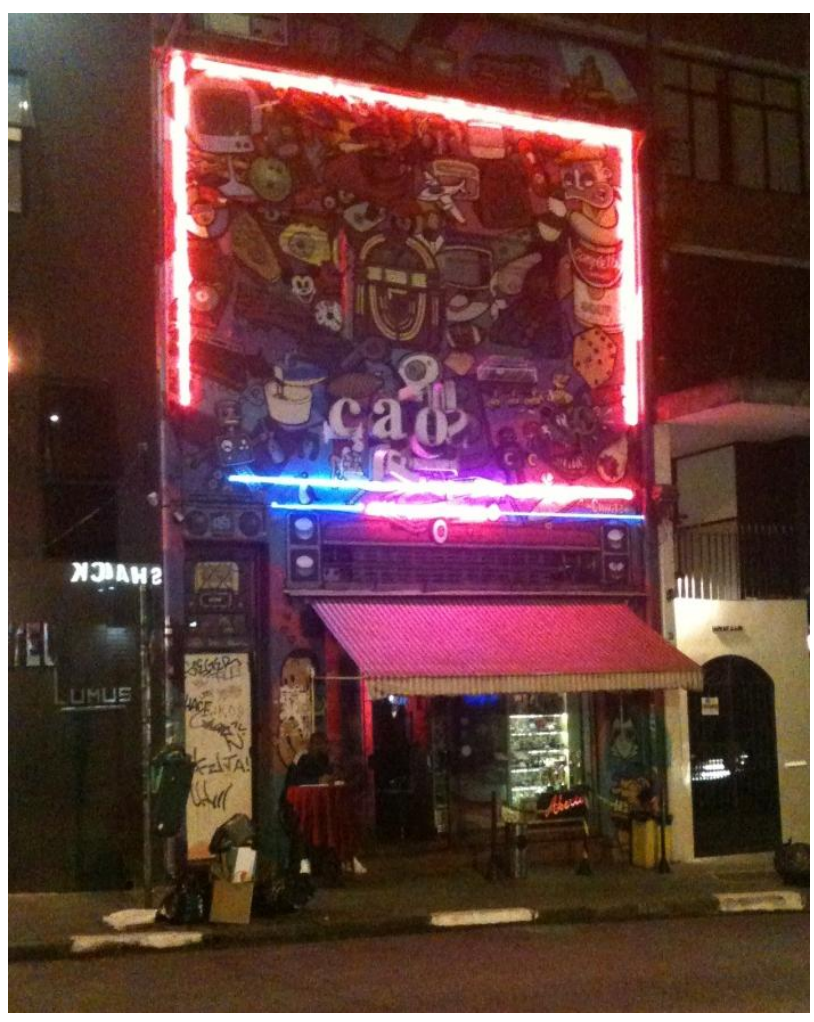

autora.

\footnotetext{
${ }^{8}$ O iluminado. Folha online. 03/07/2011. Disponível em: http://www1.folha.uol.com.br/revista/saopaulo/sp0307201108.htm

${ }^{9}$ Hype é um termo inglês que tem sido usado para designar algo que está na moda e tem uma divulgação excessiva sobre um assunto, produto ou até mesmo pessoas.
} 
Na loja Caos, a vitrine possui uma grande quantidade de objetos expostos e por serem produtos pequenos, estes ficam localizados em prateleiras, para que tenham mais destaque (Figura 60). Por se uma loja que abriga também um antiquário, onde naturalmente a diversidade de produtos é algo intrínseco ao segmento, a profusão de objetos numa mesma vitrine é justificável. Independente disso, vê-se que há uma preocupação em se agrupar as categorias de produtos, criando uma organização visual. A falha fica por conta da iluminação, que acaba criando muitas zonas de sombreamento, não valorizando as mercadorias.

Figura 60.

Vitrine da loja Caos Fonte: Acervo pessoal da autora.

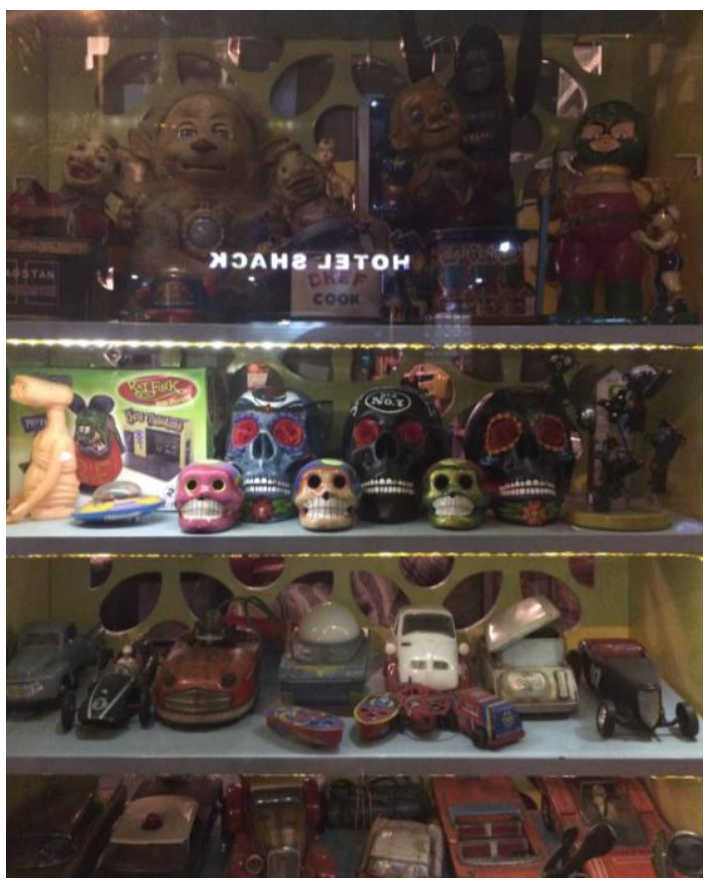

Ao entrar na loja, o excesso mantém-se como característica dominante (Figura 61). Para cada lugar que se olha, há uma descoberta. Não é à toa que o próprio dono da loja a define como uma "loja de curiosidades". 
Figura 61. Parte interna da loja Caos. Fonte: Acervo pessoal da autora.

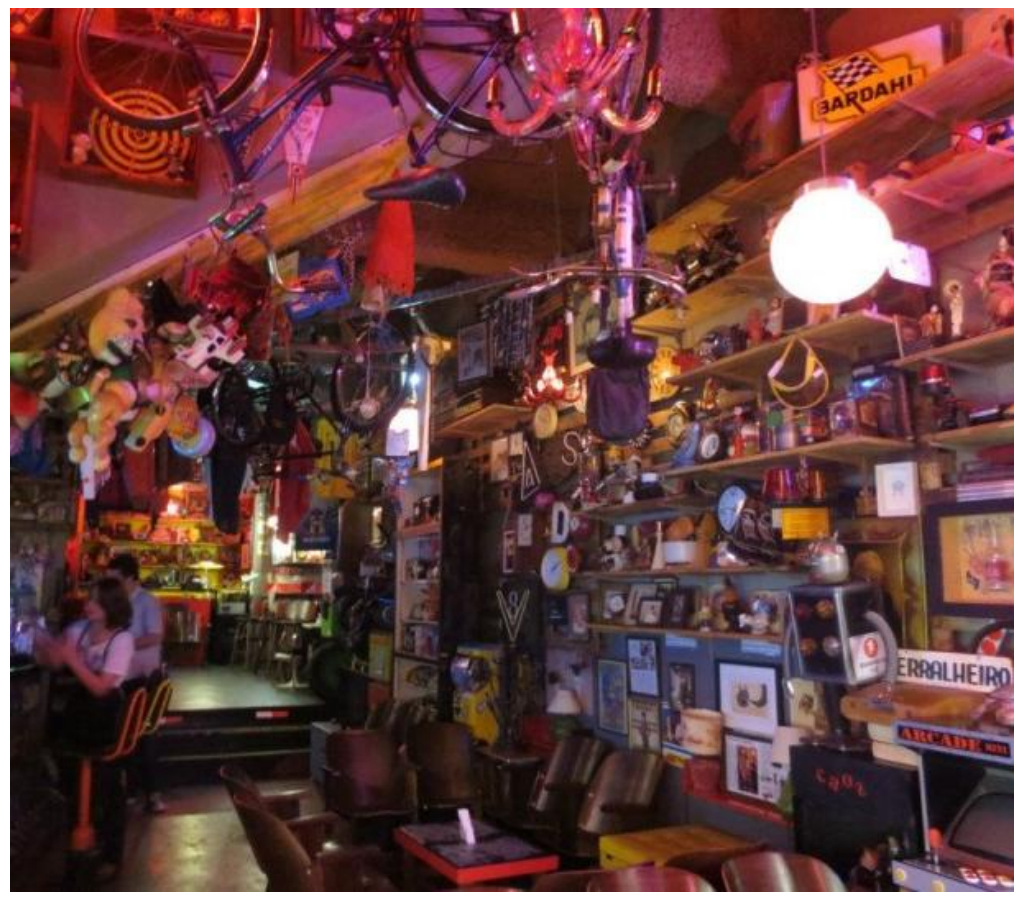

A decoração confunde-se com os objetos comercializáveis, que ora estão a venda, ora só tem a função de ambientar e criar a atmosfera da loja. Brinquedos, rádios (Figura 62), discos raros, luminárias e roupas vintages estão à disposição do usuário. Itens bastante procurados por colecionadores e profissionais que procuram objetos para locação. Além das locações, durante o dia, é possível o consumidor comprar, vender e até trocar produtos antigos na loja, enquanto saboreia algo regado a café.

Figura 62.

Rádios expostos em prateleiras dentro da loja Caos Fonte: Acervo pessoal da autora.

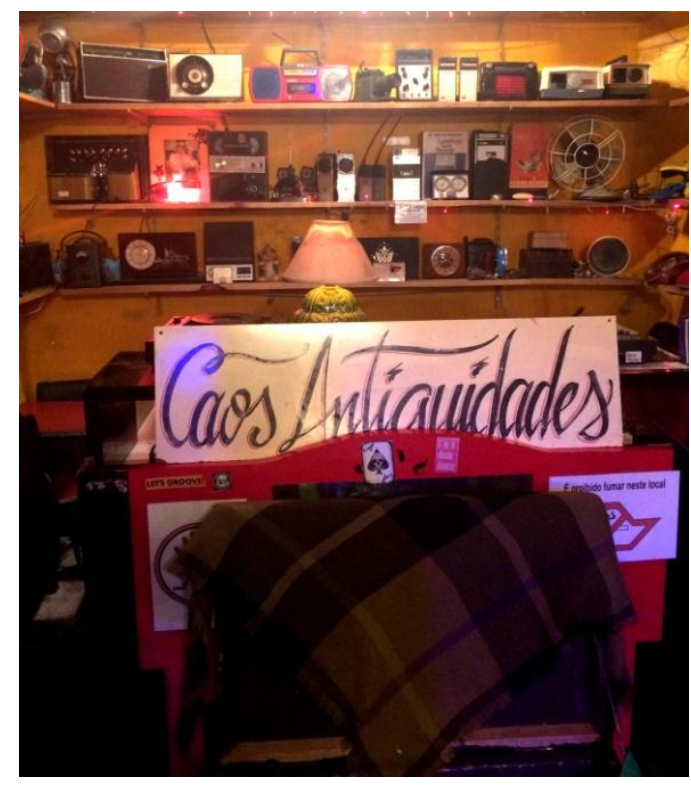


O lugar é bastante procurado por turistas, principalmente após 2012, quando a loja se tornou protagonista de uma série de televisão, no canal The History Channel, intitulado com o mesmo nome da loja, que narrou em 20 episódios o cotidiano da curiosa loja.

À noite, a loja se transforma: o balcão de atendimento torna-se o bar (Figura 63), os cafés dão lugar as bebidas alcoólicas, os cabides de roupas do brechó são retirados para abrir espaço para a pista de dança, os DJs assumem o som do ambiente e a loja vira uma descolada balada. Os 80 lugares disponíveis na casa geram concorrência, se transformando em um dos bares mais frequentados da Rua Augusta, em São Paulo.

Figura 63.

Vista do balcão e bar Fonte: Acervo pessoal da autora.

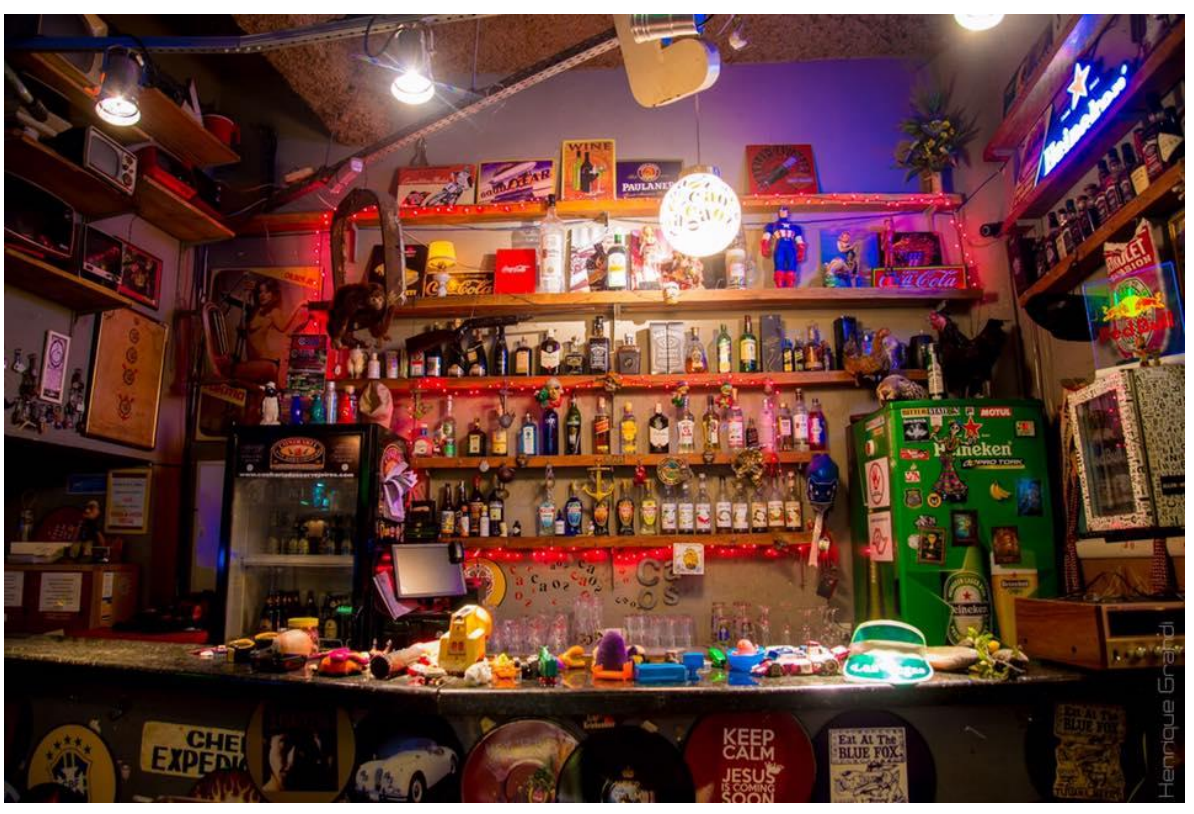

Desta forma, a loja Caos mostra sua versatilidade, renovando suas funções, num espaço mutável, que se adapta ao público e com uma configuração de espaço liberto de um programa específico.

\subsubsection{LOJA COM ESPAÇO SEMI-PÚBLICO}

A arquitetura dos ambientes comerciais tem reinventado o espaço urbano. Uma busca pela conexão com a cidade, tornando os espaços de transição cada vez mais sutis, tem sido algo explorado nas lojas do século XXI. 
Este espaços podem ser definidos como espaços semi-públicos, que são exatamente espaços de transição entre o espaço público - rua, e o espaço privado - loja propriamente dita. Ambos os espaços possuem uma relação complexa de interdependência, uma vez que o espaço gerado entre eles, não é nem completamente privado, nem totalmente público e corresponde a ambientes de socialização mais restrito e direcionado.

Um bom exemplo de loja que possui um espaço semi-público é a Galeria Melissa (Figura 64) em São Paulo. A loja é projeto do Multi Randolph e está localizada na Rua Oscar Freire na região dos Jardins. A fachada da loja possui um imenso vão livre com área superior a 100 metros quadrados e foi propositalmente projetada para abrigar eventos ao ar livre. No próprio site da loja ${ }^{10}$, o espaço é assim definido:

Na urbe mais cinza do hemisfério Sul, a Galeria Melissa São Paulo propõe um sopro de cor, forma, volumetria e vanguarda que soa como um camaleônico respiro estético na paisagem da megalópole de 20 milhões de habitantes.

Figura 64. Galeria Melissa enquanto aberta, em abril de 2014 (São

Paulo - SP) Fonte: Acervo pessoal da autora

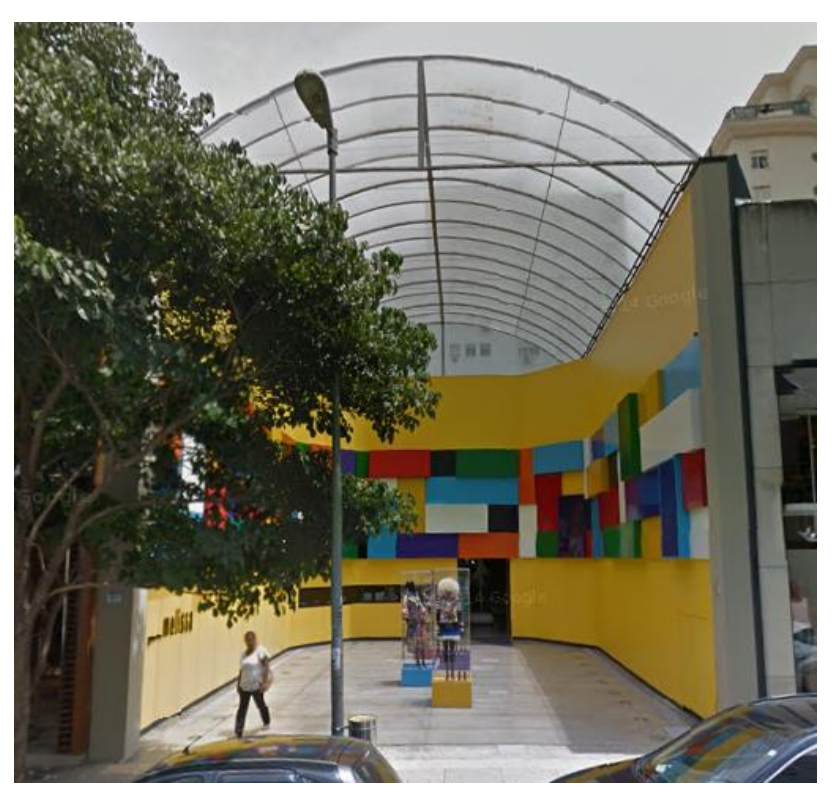

A fachada recuada foi idealizada para que esta pudesse funcionar como um grande vitrine tridimensional a ser trocada periodicamente. Desde 2005, a Galeria já recebeu um pouco mais de 30 diferentes instalações temporárias (Quadro 3), que refletiam um novo lançamento da marca, a troca de coleção ou uma nova parceria firmada. Esses temas eram manifestados na

\footnotetext{
${ }^{10}$ http://www.melissa.com.br/galerias/sp/10-years
} 
Galeria na forma de artes, instalações e padronagens - assinadas por diferentes designers e arquitetos. Esta é a essência da Galeria. Segundo o designer responsável pelo projeto, a Galeria Melissa:

foi projetada para mudar constantemente. Busco criar experiências imersivas e dinâmicas, nas quais dimensões e sentidos se confundem. Arte, pesquisa e inovação devem fazer parte do nosso dia a dia, e não se restringirem apenas à museus, galeria e laboratórios (MUTI RANDOLPH, 2015)

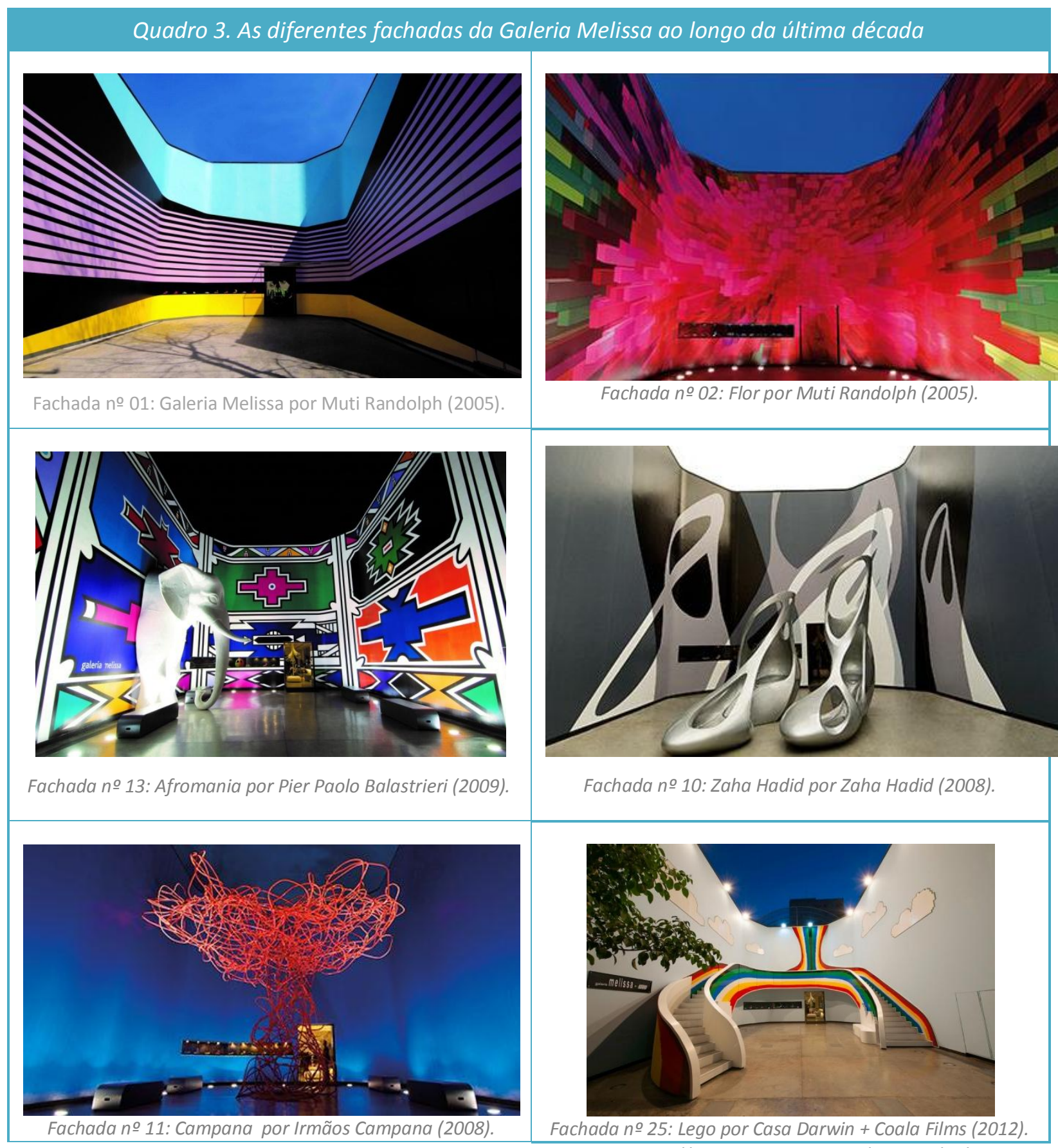

Fonte: http://www.melissa.com.br/galerias/sp/10-years 
Um fator muito interessante deste espaço semi-público, é que mesmo durante o horário de fechamento da loja (Figura 65), a grande galeria continua a ser acessada e sua vitrine suspensa ao fundo se mantém à mostra atraindo olhares dos pedestres que ali transitam.

Figura 65. Galeria Melissa durante o horário de fechamento, em junho de 2014 (São Paulo -

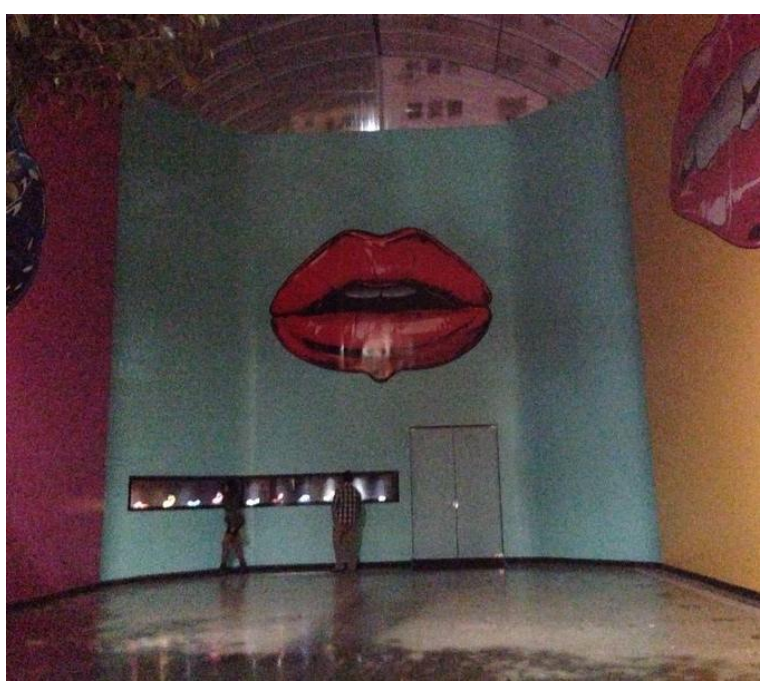

O que ocorre na Galeria Melissa a noite é algo extremamente interessante para a cidade. Soluções como esta poderiam ser replicadas em outras lojas, pois quaisquer que sejam as configurações da vitrine externa, independente da loja encontrar-se fechada, estas poderiam ser transformadas num espaço bastante diversificado, além de poder criar narrativas, até mesmo, inesperadas, constituindo espaços para descobertas informativas, culturais e estéticas, estabelecendo diálogos entre o produto e o público através de diferentes formas.

Pode-se pensar que o investimento em fachadas interativas e/ou diferenciadas no horário de fechamento apenas se torna viável economicamente por onde há a circulação do consumidor em potencial, porém sua existência em si já é uma excelente forma de comunicação de marca e atração de consumidor.

A importância de uma comunicação com o consumidor é inquestionável e o papel da vitrine nisso se torna fundamental. Tal pensamento é reforçado por Sackrider:

Se os olhos são as janelas da alma, as vitrinas revelam a alma da loja. Elas comunicam dia e noite, numa exposição duradoura que vive até a saída do último cliente e continua noite adentro. Assim, a vitrina é certamente o elemento exterior fundamental do ponto de venda. Capital para a 
identificação da marca, a vitrina é o reflexo dela mesma e de seus produtos, com o intuito de reforçar o estilo da marca e focar o seu posicionamento em relação ao consumidor. (SACKRIDER, 2009, pg. 10)

Utilizar a vitrine ativa durante todos os momentos, independente da loja se encontrar aberta ou fechada é reforçar o posicionamento da marca perante o consumidor, além de contribuir com a dinâmica da cidade.

Logicamente, em lojas populares - que atraem seu consumidor apenas pelo preço baixo, ou em restaurantes fast-food talvez o uso de vitrines não seja algo primordial e necessário, mas mesmo assim um fechamento que fosse além das esteiras metálicas poderia ser considerado. Em São Paulo, exemplos como a loja Havaianas (Figura 66) da Rua Oscar Freire demonstram claramente que não é necessário fazer um projeto de fechamento apenas visando a continuação da comunicação do produto ao consumidor, mas simplesmente a arte de estabelecer a arquitetura como um verdadeiro anúncio da marca, pode transmitir de maneira muito mais eficiente os conceitos do produto ali comercializado.

Figura 66. Loja Havaianas aberta e fechada

(São Paulo)

Fonte:
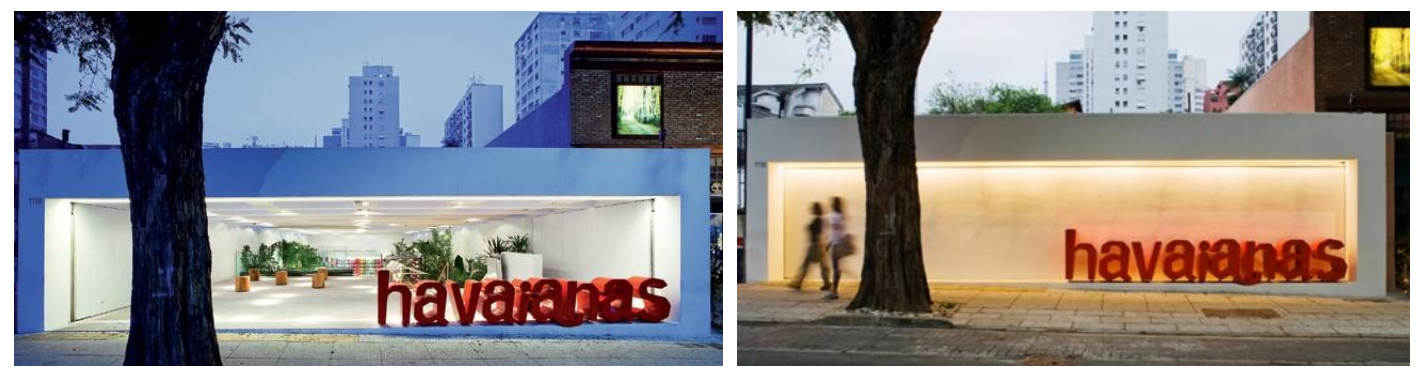

Uma outra possibilidade a ser explorada é comunicar a marca, enquanto a loja ainda está em reforma ou antes mesmo de ser aberta. O que poderia ser um simples tapume, cobrindo a fachada da loja e anunciando que em breve ela será reaberta, pode se tornar um verdadeiro display dos valores, conceitos e produtos da marca.

Talvez a primeira a utilizar deste artifício na frente de sua loja durante uma reforma foi a loja da Louis Vuitton em Paris, que se utilizou das suas bolsas em grande escala para cobrir a fachada em reforma (Figura 67). Um pouco depois a francesa Goyard (Figura 68), utilizou do mesmo artifício para cobrir sua loja que antes de ser inaugurada e um pouco mais recente a Dior fez na sua em Nova lorque (Figura 69). 
Figura 67. Loja da Louis Vuitton na Champs-Elysees em Paris.

Fonte:

http://mainamorena.blogspo t.com.br/2010_04_11_archiv

Figura 68

Mala gigante da Goyard, indicando a localização da futura loja na Mount Street -

Inglaterra.

Fonte:

https://ameconsultoria.word press.com/2010/09/15/openi

ng-soon/

Figura 69.

Loja da Christian Dior na 57th Street em Nova lorque, com um tapume em formato de uma bolsa gigante com os dizeres "Fechada para renovação. Inauguração em dezembro de 2010".

Fonte:

https://bruegio. wordpress.co m/2010/08/17/default-59/
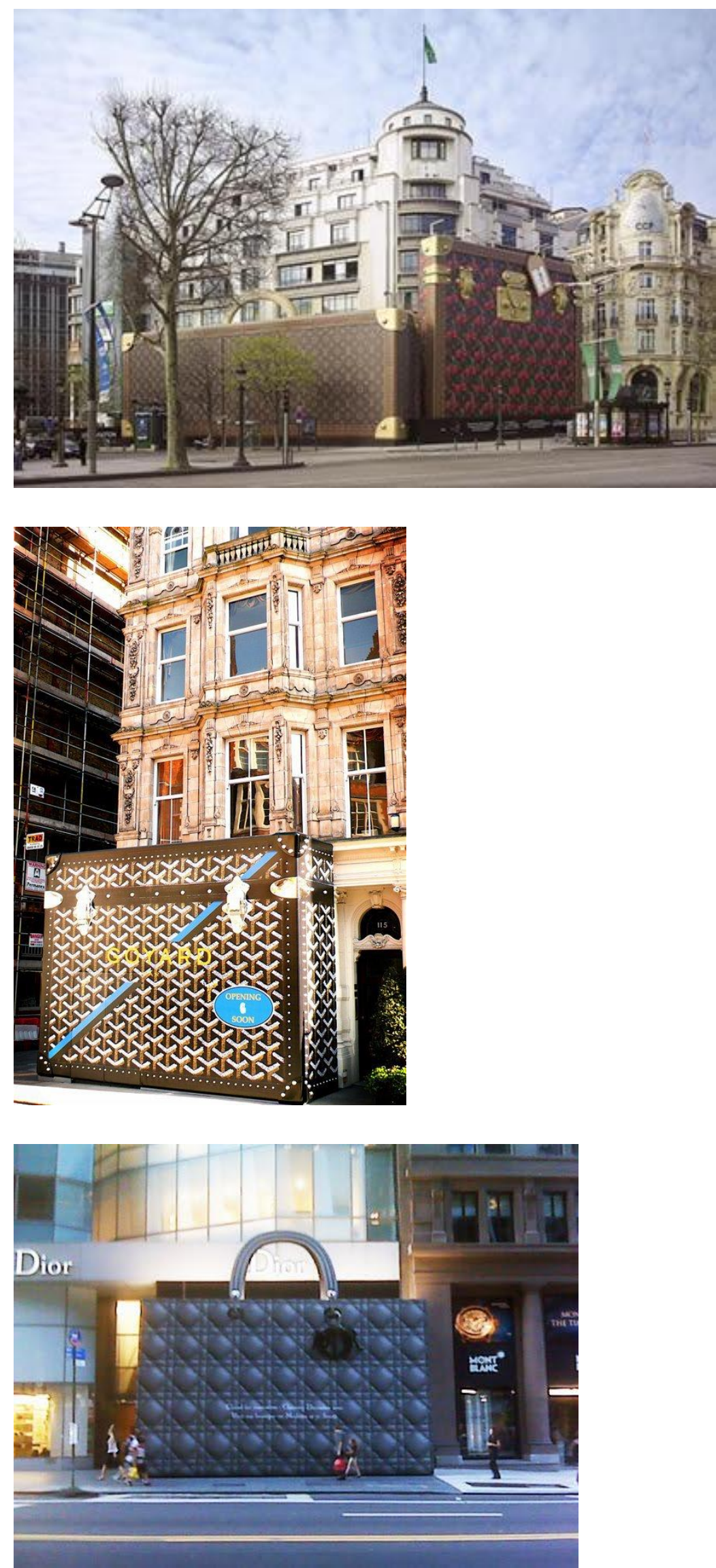


\subsubsection{LOJA EXPERIÊNCIA}

Muitas lojas cientes da importância de promover uma experiência de consumo ao invés de simplesmente vender um produto, têm investido na criação de espaços que permitam ao consumidor vivenciar numa experiência de lazer.

Uma das melhores definições sobre a experiência de consumo é do autor Csikszentmihalyi (1990), que conceitua como um intenso grau de sentimento positivo oriundo de uma completa absorção e envolvimento por parte do consumidor, e que deste modo, transforma-se em algo memorável na percepção do mesmo. Hirschman e Holbrook (1992), autores reconhecidos no estudo de experiência e suas ligações com analises psicológicas do consumo, acreditam que a busca do consumidor por sensações mais fantasiosas o feito se aproximar de uma vivência de emoções mais concretas e que, assim, permitem uma maior absorção dos conceitos de experiência. Dessa forma, as características de experiência do consumidor são aproximadas de questões hedônicas, simbólicas, fantasiosas, sentimentais, sensitivas e divertidas. Tudo isso para efetivamente criar para o consumidor uma atmosfera de experiência de consumo (HIRSCHMAN; HOLBROOK, 1992).

A fuga da realidade em busca destas sensações tem aproximado o consumidor da busca por inquietações sensoriais-emocionais de modo a absorver e desejar de forma mais consistente o conceito de experiência.

Assim, as lojas que exploram o conceito da experiência de consumo, tem criado lojas que são verdadeiros ambientes laboratoriais, espaços exploratórios de descoberta, onde é gerado uma série de experiências para o consumidor, de modo a proporcionar um contato direto e mais íntimo com a marca.

Este tipo de loja tem-se se difundido pelo mundo, mas ainda aparece de maneira muito tímida e pontual no Brasil.

Em São Paulo, por exemplo, em junho de 2015, aconteceu uma ação da loja Decathlon para apresentar sua nova coleção de inverno e suas marcas 
exclusivas de esportes de montanha, Quechua e Wed'ze. Nesta ação a loja promoveu aos usuários a experiência de vivenciar um ambiente com temperatura abaixo de zero.

Um pequeno contêiner foi aberto ao público na loja Decathon do Morumbi (Figura 70), em que a temperatura chegou a marcar 10 o negativos. Ao chegar, o consumidor era instruído por um especialista em produtos de esportes de montanha, sobre o sistema de 3 camadas e a importância de cada peça para a proteção contra o frio e para a prática segura e confortável dos esportes de inverno. Após isso, o consumidor era convidado a se vestir com os produtos selecionados pela marca - casacos, calças, luvas e tocas, e depois era só entrar no contêiner (Figura 71) e vivenciar a experiência de temperaturas negativas.

Figura 70.

Entrada do contêiner da Experiência Zero Grau da loja Decathlon Fonte: http://www.runningnews.co $\mathrm{m} . \mathrm{br} /$ noticias/faz-acao-comexperiencia-abaixo-de-zeroem-sao-paulo/2015/06/

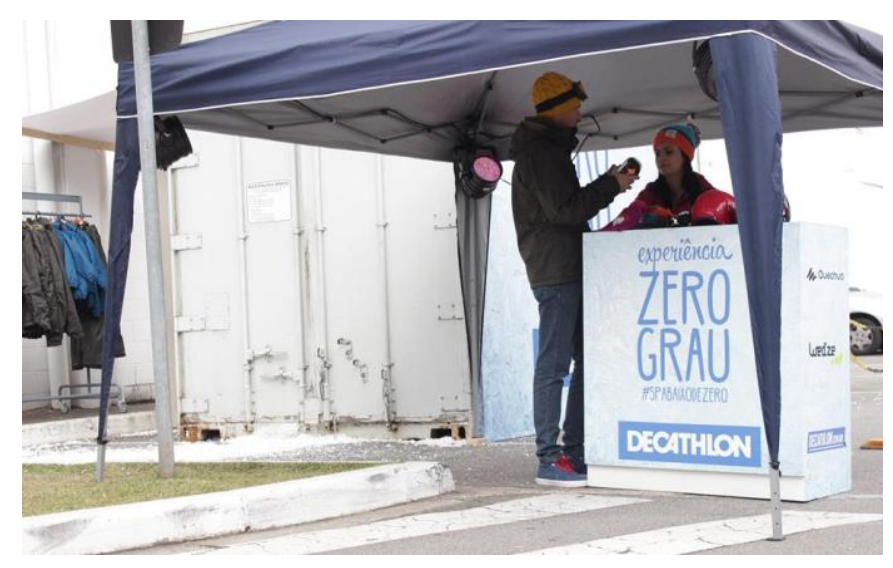

Figura 71. Espaço interno do contêiner onde ocorria a experiência Zero Grau. Fonte: http://www.runningnews.co m.br/noticias/faz-acao-comexperiencia-abaixo-de-zeroem-sao-paulo/2015/06/

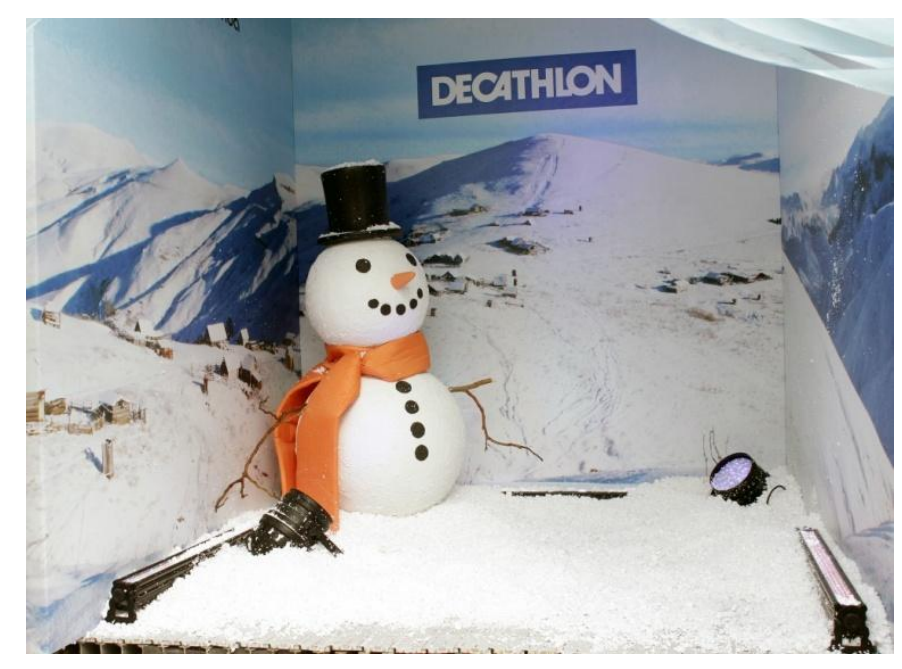

Um exemplo onde era possível vivenciar uma experiência de consumo é a Build-a-Bear Workshop (Figura 72). Inaugurada em junho de 2011 no shopping Eldorado em São Paulo, a loja ficou em funcionamento por alguns 
anos, tendo encerrado suas atividades no Brasil há pouco mais de 2 anos. A loja era uma filial da marca americana, que surgiu em 1997 e hoje conta com lojas espalhadas em outros 14 países ao redor do mundo. Nela é possível ter uma experiência única ao criar seu próprio urso de pelúcia.

Figura 72.

Loja Build-a-bear worshop do shopping Eldorado (São

Paulo)

Fonte: Acervo pessoal da autora.

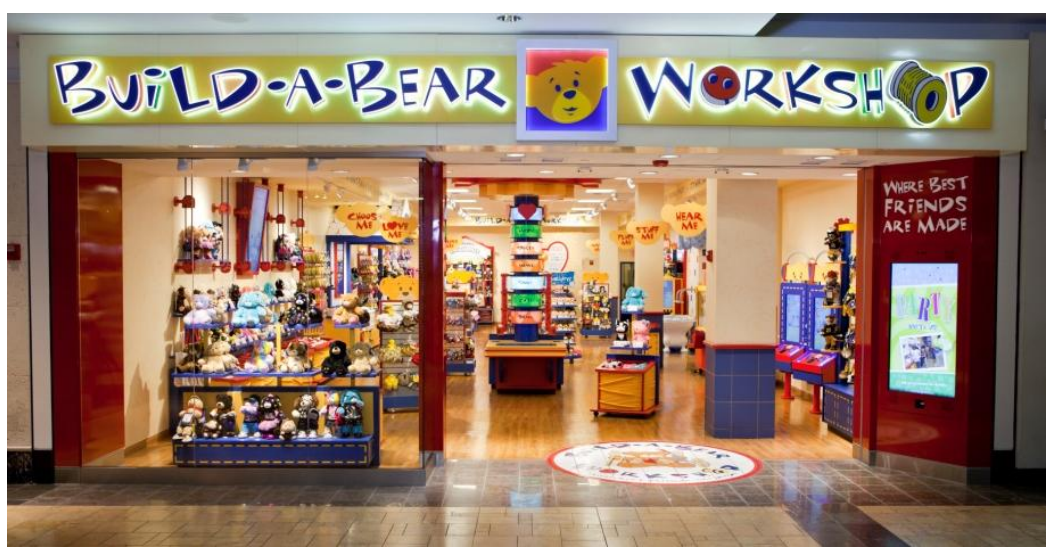

A experiência é dividida em oito etapas (Figura 73), começando com a escolha do urso que o consumidor deseja montar, dentre mais de 30 opções de animais disponíveis, que incluem ursos, coelhos, cães e personagens de desenhos famosos. O interessante nesta fase é que o urso de pelúcia escolhido vem com o corpo vazio (Figura 74) e é o próprio consumidor que vai até a máquina de enchimento (Figura 75) e "recheia" o bichinho até o ponto que desejar, deixando-o mais fofo ou mais duro.

Figura 73.

O processo da experiência na Loja Build-a-bear worshop Fonte: http://www.form aes.com.br/

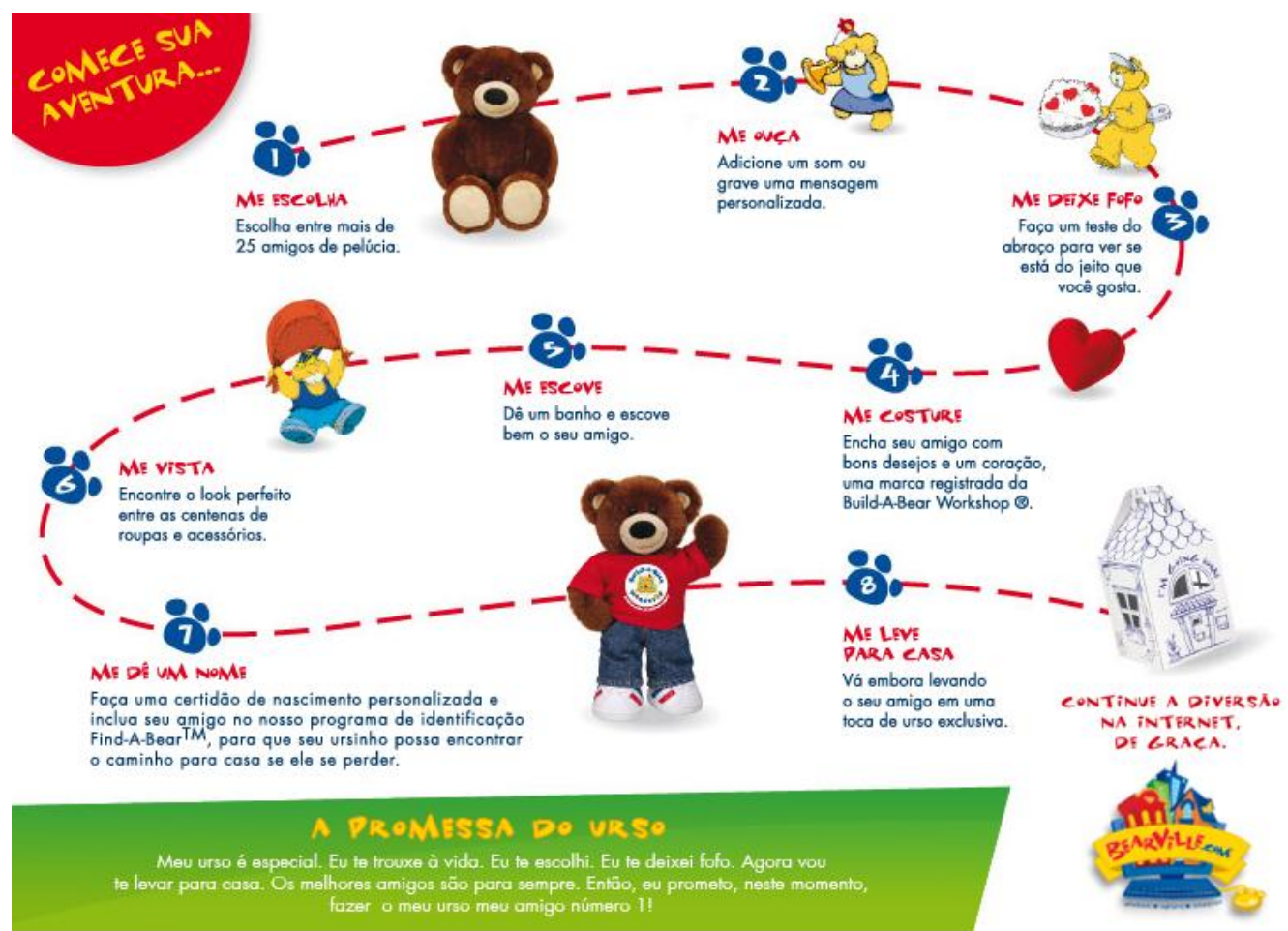


Antes de finalizar o processo do enchimento, o usuário ganha um coração que será colocado no interior do ursinho (Figura 76), mas não antes de segurá-lo entre as mãos e fazer um pedido.

Em seguida, é possível gravar uma mensagem especial ou escolher entre os sons e músicas pré-gravadas que será tocada quando apertar a mãozinha do ursinho. Após isso, o processo de enchimento é então finalizado e o funcionário costura o ursinho e orienta ao usuário passe para a próxima fase do processo, denominada "me escove". Nela o usuário leva seu bicho de pelúcia a um ambiente que simula uma banheira (Figura 77), onde um chuveiro exala ventos com produtos que deixam o ursinho mais cheiroso, enquanto o usuário o escova para que ele fique mais fofinho.

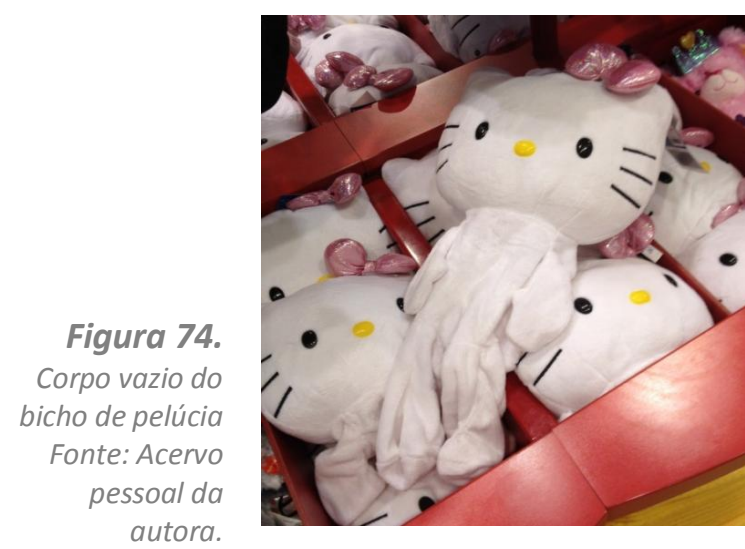

Figura 75.

Máquina de enchimento do bicho de pelúcia

Fonte: Acervo pessoal da autora.

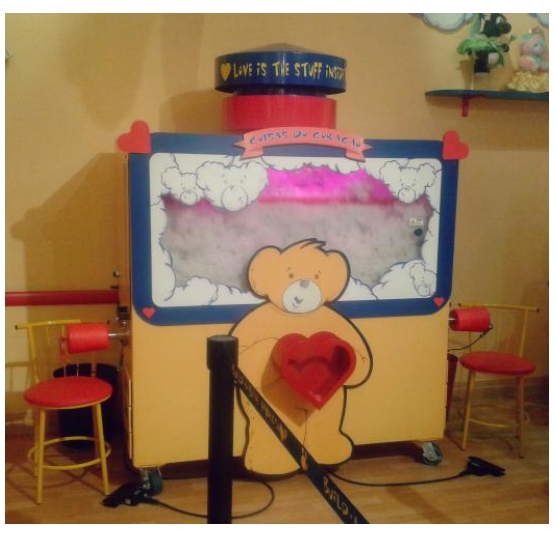

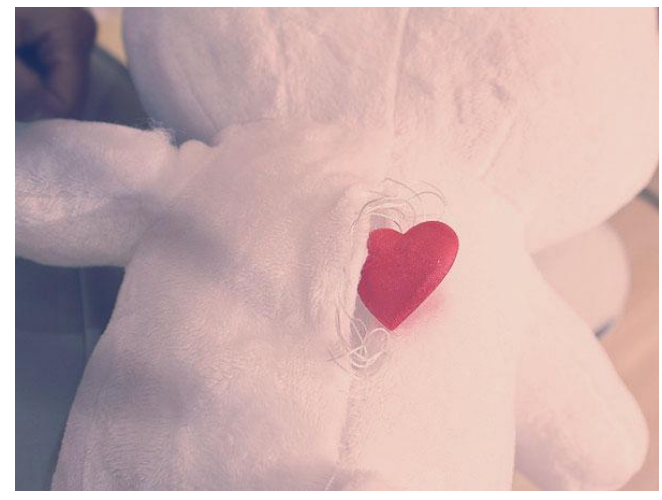

Figura 76. Coração sendo colocado no interior do bicho de pelúcia

Fonte: Acervo pessoal da autora.

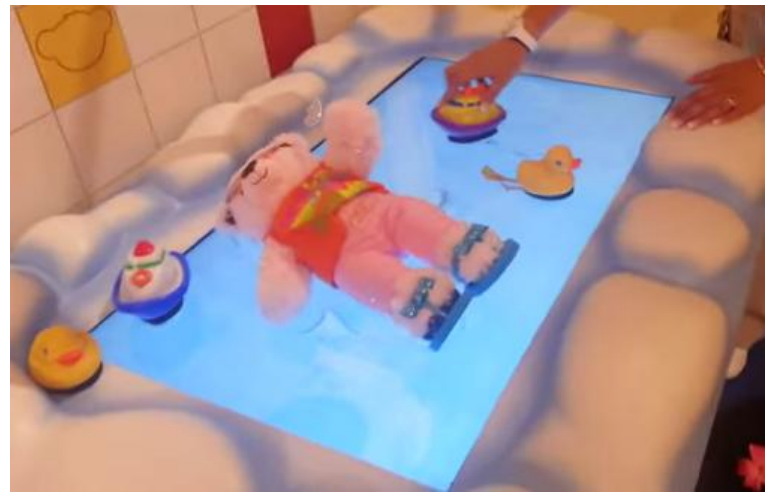

Figura 77. Ambiente que simula a hora do banho Fonte: Acervo pessoal da autora.

Feito isso, chega a hora de escolher as roupinhas e vestir o seu amiguinho (Figura 78), dentre as infinidades de opções de roupinhas e acessórios, que vão desde personagens famosos até fantasias de petiscos. Após isso, o 
usuário pode levar seu bichinho até um provador especial (Figura 79), onde é possível experimentar as roupas escolhidas.

Com o seu ursinho pronto, o usuário escolhe um nome e registra a certidão de nascimento do ursinho (Figura 80), pra ele poder ter uma vida profissional, amigos, ir ao médico, fazer compras, etc. Tudo isso numa comunidade virtual da Build-a-Bear, onde todos os ursos se encontram pra brincar.

Depois chega a hora de passar no caixa, onde é necessário que o usuário faça o juramento do urso (Figura 81) e tem a opção de adquirir um passaporte para seu urso - pataporte (Figura 82), assim ao levar o ursinho em viagens internacionais para conhecer outras filiais da Build a Bear pelo mundo, o usuário pode colecionar carimbos no passaporte. Por fim, para levar seu urso embora, este é colocado numa caixa com formato de casinha (Figura 83).

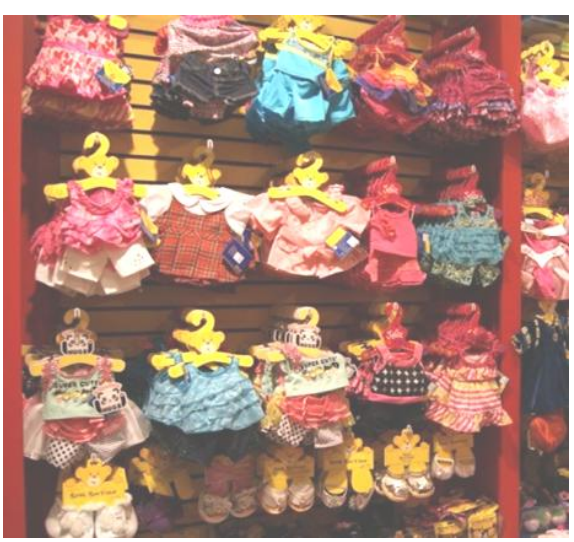

Figura 78. Exposição das roupas a venda. Fonte: Acervo pessoal da autora.

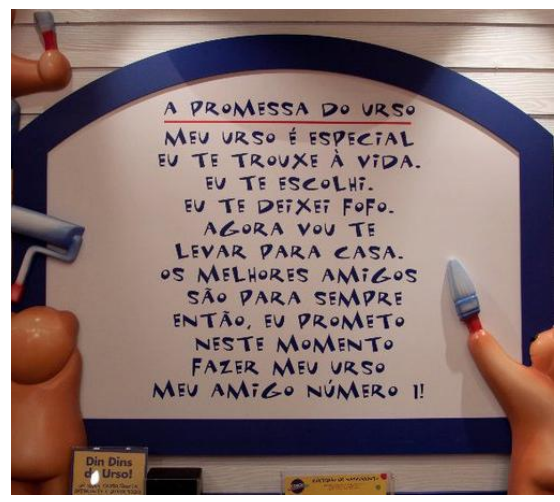

Figura 81. Juramento do urso fixado na parede.

Fonte: Acervo pessoal da autora.

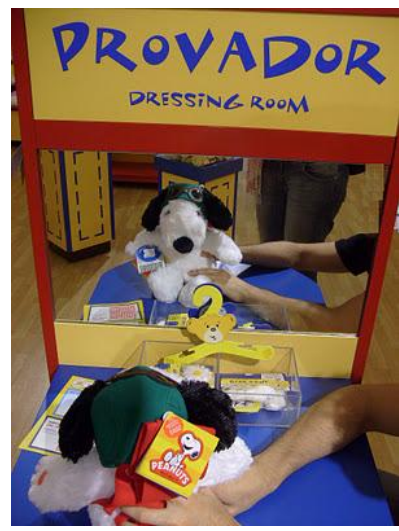

Figura 79. Provador para o bicho de pelúcia

Fonte: Acervo pessoal da autora.

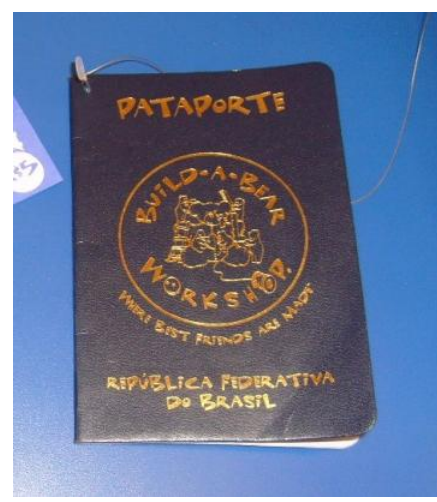

Figura 82. Pataporte do urso de pelúcia. Fonte: Acervo pessoal da autora.

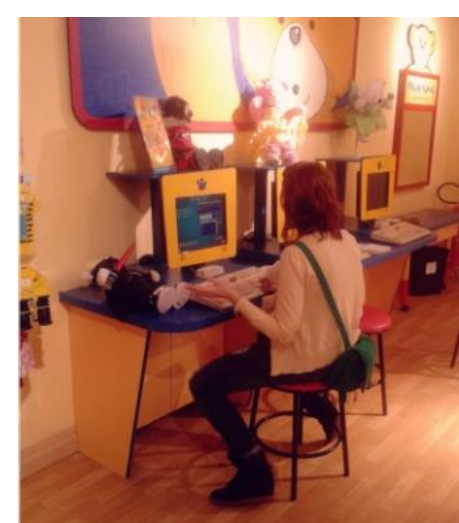

Figura 80. Lugar de registro da certidão de nascimento do urso. Fonte: Acervo pessoal da autora.

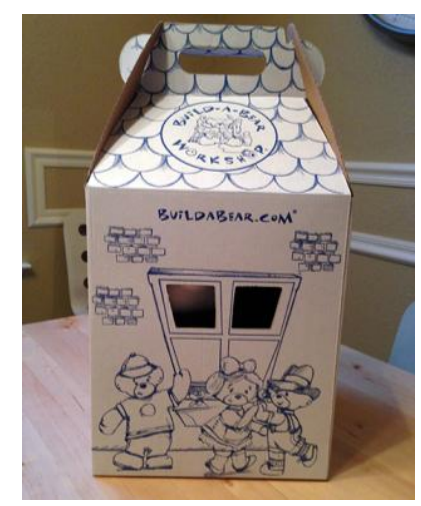

Figura 83. Caixa-sacola do urso de pelúcia da Build-a-bear Fonte: http://frugalnovice.com/2013/11/ 
A loja vende sonhos em formato de ursos de pelúcia, através de uma experiência lúdica incrível para qualquer usuário, onde o envolvimento criado pela marca ao fazer o consumidor participar de todo o processo de fabricação, transforma-se em algo memorável e único.

\subsubsection{LOJA CONCEITO}

É diante do atual consumidor hedonista, que busca experiências reais e prazerosas, que o ponto de venda tem adotado uma nova configuração e passou a exercer também o papel de meio de comunicação. Grande exemplo disso são os pontos de vendas denominados "Ioja conceito", que prometem uma vivência sensorial da marca aos consumidores, por meio de estímulos de todos os sentidos. Segundo definição de Plascak (2008, p.5), a loja-conceito é "o espaço sensorial da marca, onde todas as suas manifestações falam a mesma língua e permitem uma relação direta com o cliente, através dos sentidos".

Assim, o ponto de venda se torna uma interface entre consumidor e a marca, onde é criado um ambiente que inspire narrativas. Neste sentido, as lojas conceito são erguidas como locais de assinatura de uma marca, ou seja, locais onde ocorrem a representação máxima da identidade da marca e onde seus conceitos encontram-se estampados em todas as suas possibilidades.

A Farm tem utilizado deste preceito para a elaboração de todas as suas lojas (Figura 84). A marca tem investido em lojas conceito, que possuem projetos de grande personalidade, com inspiração no comportamento e estilo de vida da mulher carioca, despertando a curiosidade do usuário e, o mais importante, intensamente conectada com seus conceitos. 
Figura 84. Loja FARM do Iguatemi de São Paulo Fonte: Acervo pessoal da autora.

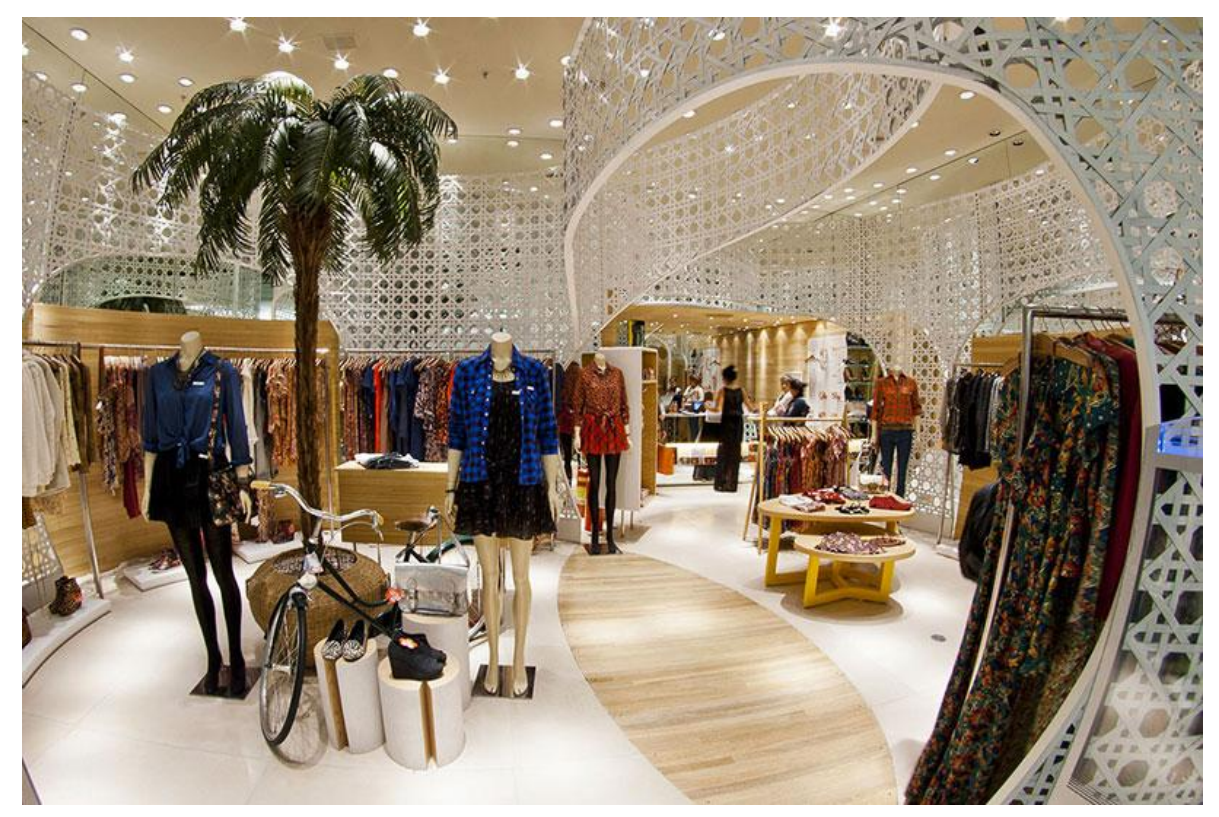

A Farm explora ao máximo a estação do ano que melhor expressa a sua marca: o verão. Coqueiros, revestimentos naturais, como madeira e pedras, e uma iluminação quente trazem a ambiência necessária para seu ponto de venda.

Num clima praiano e bem tropical, as lojas trazem a atmosfera carioca para o ambiente, com um movimento que se repete nas estampas das roupas, que trazem a personalidade do Rio de Janeiro.

Todas as lojas possuem um aroma produzido exclusivamente para a marca, que funciona como uma identidade olfativa. Segundo LINDSTROM (2007) os odores personalizados ajudam os consumidores a codificar a marca somente pelo olfato, além de remeter a uma boa sensação somente pela memória olfativa.

Além da identidade olfativa, a Farm explora a memória auditiva, possuindo uma rádio própria com uma seleção das músicas tocadas nas lojas, compatíveis e direcionadas para as preferências do público alvo da loja. Desta forma, a rádio Farm funciona como um conector emocional com os usuários, difundindo também o conceito da marca através dos sons.

Em 2009, a marca inaugurou em São Paulo, na Vila Madalena, uma loja de rua que se destaca na paisagem de São Paulo pelo seu design moderno, conciliando conceitos de sustentabilidade e arquitetura verde. 
A loja denominada Farm Harmonia (Figura 85), está completamente em sintonia com todos os conceitos que a marca deseja transmitir aos seus usuários. Todo o prédio que funciona como um jardim vertical, é muito verde e tira partido da iluminação natural para criar a atmosfera natural.

A loja possui 2 andares, sendo no térreo a recepção da loja e o "Espaço Praia", no primeiro andar encontra-se a parte de lançamentos e provadores e no último andar fica o bazar com todas as coleções passadas e outros provadores.

Figura 85.

Loja Farm Harmonia Fonte: Acervo pessoal da autora.
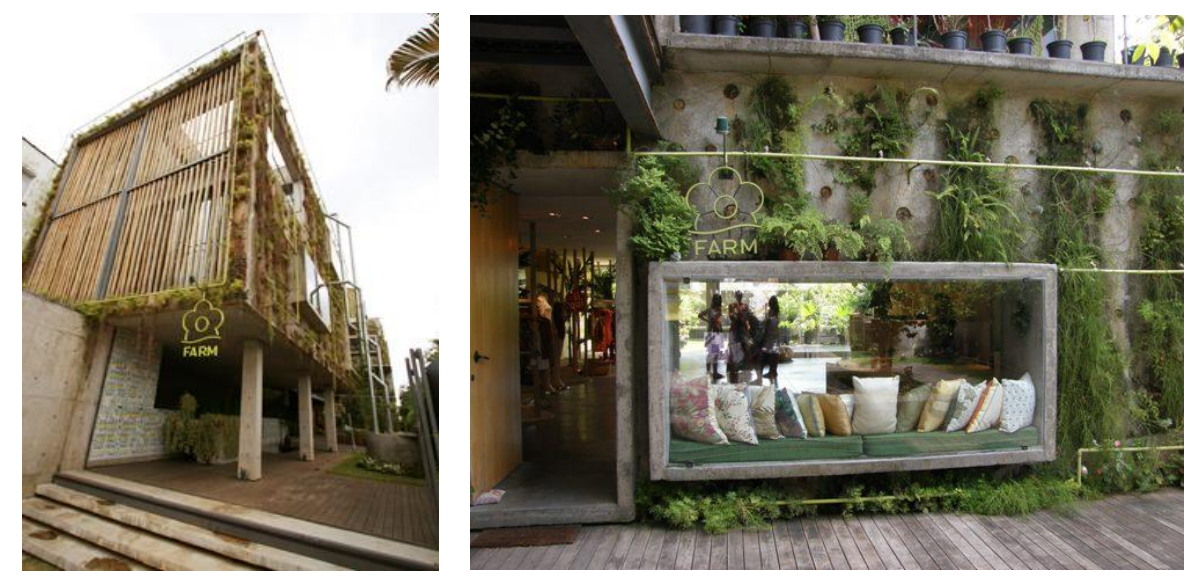

\subsubsection{LOJA ESCULTURAL}

Os aspectos externos da edificação, ou seja, o invólucro que dá forma a loja, são extremamente importantes para atrair o consumidor, uma vez que é através da arquitetura que se terá a primeira impressão sobre o ambiente comercial e consequentemente, estimar a qualidade e o tipo de loja. Por meio de aspectos como visibilidade, tamanho, estilo arquitetônico, material de acabamento, fachada, comunicação externa, vitrinas e conservação a loja projeta a sua imagem. Esta imagem pode transmitir diversos conceitos, como sofisticada, popular, conservadora, jovem, entre outros (PARENTE, 2000).

Não faltam exemplos em São Paulo de lojas que explorem o projeto arquitetônico como uma forma de comunicar-se com o consumidor. A loja 
que funciona como showroom das marcas Ferrari e Maserati, instalada na esquina da Avenida Brasil com Rua Venezuela faz parte desta categoria.

Uma loja de arquitetura escultural impressiona os observadores que por ali transitam. Transmitindo conceitos de elegância, sofisticação e modernidade, o projeto alia-se aos preceitos de exclusividade associados às marcas comercializadas neste espaço.

Os requisitos do projeto solicitam que as fachadas fossem transparentes, para expor os veículos Ferrari e Maserati, mas protegidas de forma a garantir o conforto ambiental. A criação de uma malha metálica com planos inclinados e formas não ortogonais, vedada por elementos opacos e transparentes, atendeu a estas condicionantes (Figura 86).

Figura 86. Edifício da loja Ferrari e Maserati. Fonte: Acervo pessoal da autora.

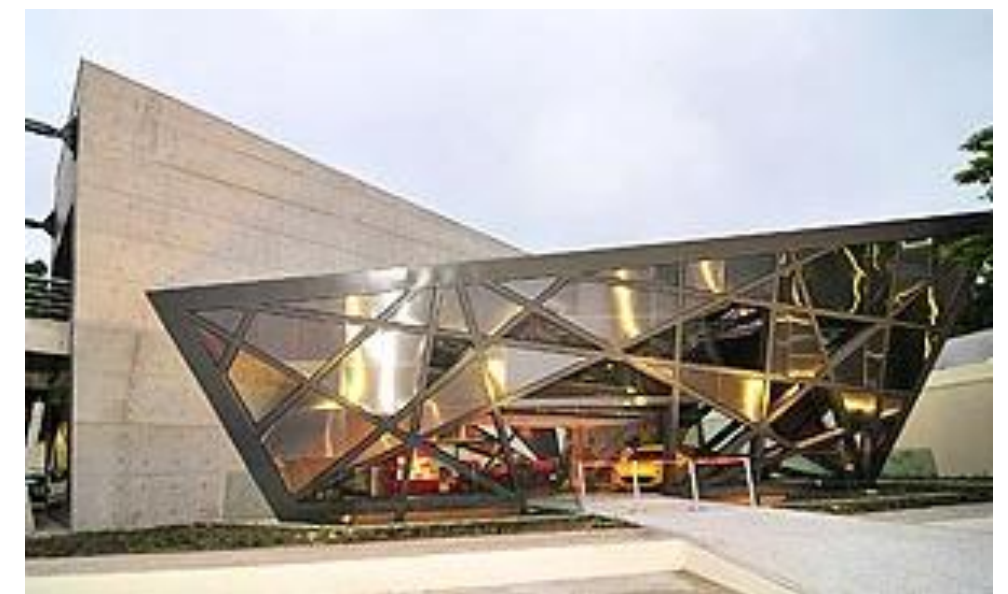

O projeto desenvolvido pelos arquitetos do escritório Noosfera Arquitetura, possui uma área construída de 1.500 metros quadrados. Implantado em um lote de esquina, o prédio tem três partes diferenciadas pela função, formato, tratamento de materiais e setorização. A partir de um eixo diagonal no terreno foi desenhado o corpo central, em concreto, do qual se destacam duas partes estruturadas em aço (Figura 87), que abrigam no térreo o salão de exposições. Nelas, fachadas e coberturas se transformam em uma única pele, tornando o edifício uma escultura moldada, resultado de um trabalho em malha metálica executado sem modularidade. 
Figura 87. Maquete eletrônica com vista superior da edificação da loja Ferrari e Maserati. Fonte: https://arcoweb.com.br/fines tra/arquitetura

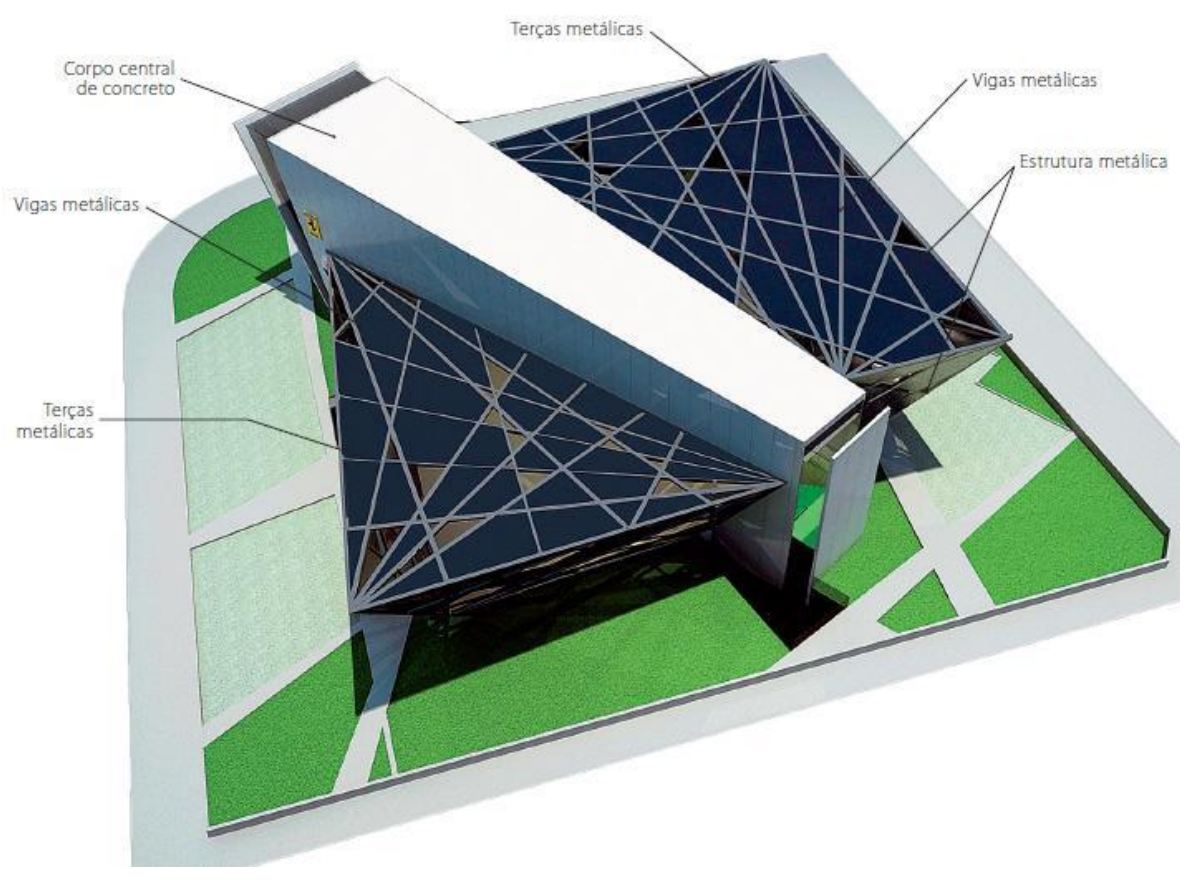

\subsection{COMPOSIÇÃO DE VITRINE}

A composição de vitrines requer o entendimento de algumas categorias e técnicas fundamentais utilizadas no campo do design visual. Elementos básicos de composição visual estruturadores de projeto se aliam para tornar possível a comunicação: linhas, planos, volumes, luz e cor.

A composição destes elementos tem por objetivo tornar o espaço comercial mais atraente. Para que isso seja alcançado é necessário conciliar diferentes fatores, como a quantidade de elementos a serem distribuídos no espaço e a forma como serão ordenados. Influenciará também no resultado final da composição, a própria dimensão da vitrine, seu espaço físico como um todo, bem como o meio que a loja está inserida, pois o ambiente externo é determinante da definição do campo visual do observador.

Inúmeras são as combinações que podem resultar dos diferentes arranjos organizados com os objetos no espaço da vitrine. Independente da combinação a ser feita, segundo Demetresco (2005) existem três princípios básicos que regem uma boa composição: o equilíbrio, o ritmo e a unidade. 
O equilíbrio, como qualquer outro item referente à composição, pode ser explorado separadamente, mas independente de que seja esta a escolha, inevitavelmente este acabará interagindo com os outros.

Uma composição equilibrada transmite a sensação de ordem, de estabilidade, aproveita a potencialidade dos seus componentes. Através do equilíbrio é possível ordenar o espaço, o roteiro visual, o tempo de apreensão da composição, estabelecer o vínculo entre o observador e a composição da vitrine. $O$ equilíbrio é importante em qualquer composição, seja esta artística ou não, pois evita a ambiguidade e favorece a clareza da mensagem transmitida. O desequilíbrio, por sua vez, pode produzir múltiplas interpretações, algumas delas indesejáveis para um ambiente comercial, como a sensação de amadorismo e de inacabado.

Fatores específicos em termos de percepção visual influenciam no equilíbrio, como as características dos elementos visuais, a propriedade física dos elementos, seus valores agregados e, obviamente, a posição dos objetos na composição, se estão acima, abaixo, à direita ou à esquerda do centro visual de equilíbrio. Segundo Pinto (2005) o arranjo destes fatores irá proporcionar um efeito de completude à manifestação visual.

Tal completude, caracterizada pela ausência de tensão ou por sua pausa, é o que se pode chamar de equilibrio. Por sua vez, este não significa necessariamente monotonia ou simplicidade absoluta. De acordo com Ching (1998, p. 320), para a arquitetura, "ordem sem diversidade pode resultar em monotonia e enfado; diversidade sem ordem pode produzir o caos". (PINTO, 2005, p. 64)

O equilíbrio na vitrina pode ser obtido tanto por uma composição simétrica ou assimétrica. Na simetria (Figura 88), a distribuição dos elementos, linhas e formas é feita de maneira equivalente a partir de um eixo central imaginário da vitrine, que divide o espaço em dois. A simetria proporciona um equilíbrio elementar e primário e transmite mensagem de ordem, rigidez, formalismo, pois é uma composição mais estática. Normalmente esta é utilizada na vitrine quando há compatibilidade e semelhança na cor, forma e tipo de elementos que serão expostos. 
Figura 88.

Vitrine com composição simétrica a partir de um eixo

central vertical da loja Selfridges de Londres (2012)

Fonte:

http://blog.usefashion.com/b log/conteudo.aspx?idconteud $o=104194$

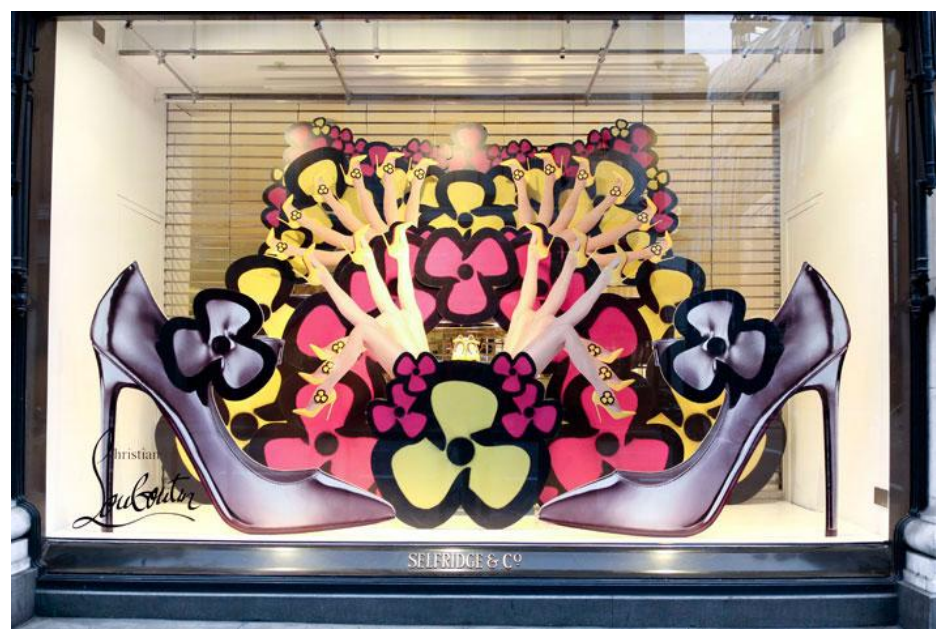

De acordo com Lourenço e Sam (2011), existem três tipos de simetria: rígida, variável e polar (Figura 89).

Figura 89.

Esquema demonstrando a simetria rígida, variável e polar, respectivamente. Fonte: Elaborada
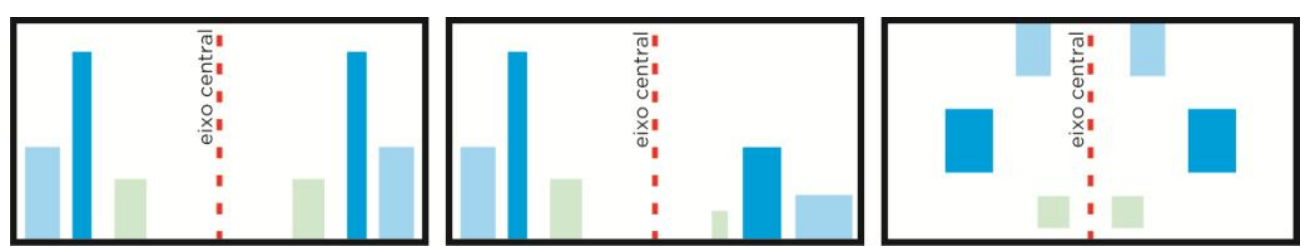

pela autora.

A vitrine possui simetria rígida, quando os dois lados da composição são reciprocamente idênticos; variável (Figura 90), quando se mantém a simetria apenas na forma e/ou ordenação; e polar, também denominada radial, (Figura 91), quando as formas estão dispostas de forma circular em direção a um produto ou grupo de produtos.

Figura 90. Vitrine com simetria variável, pois se percebe que ao traçar um eixo central os elementos que compõem cada lado da vitrine não são exatamente idênticos, mas estão distribuídos da mesma maneira. Fonte: https://br.pinterest.com/pin/ 285415695104463828/

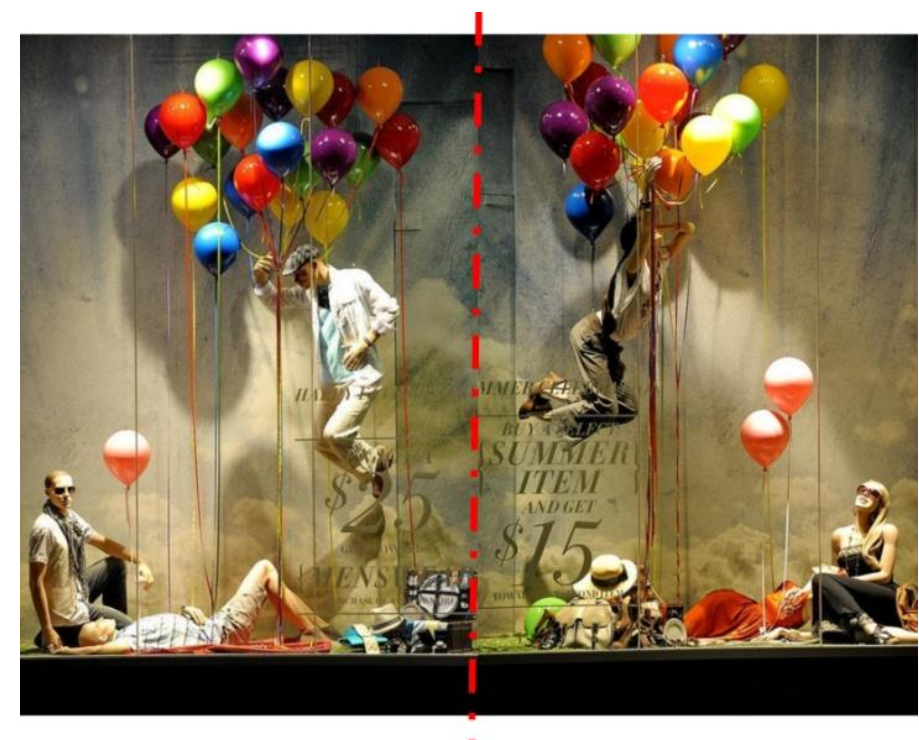


Figura 91.

Vitrine da loja Louis Vuitton com composição simétrica polar, onde o produto exposto é colocado no centro

do eixo focal, enquanto os elementos decorativos estão dispostos radialmente. Fonte:http://retaildesignblog.

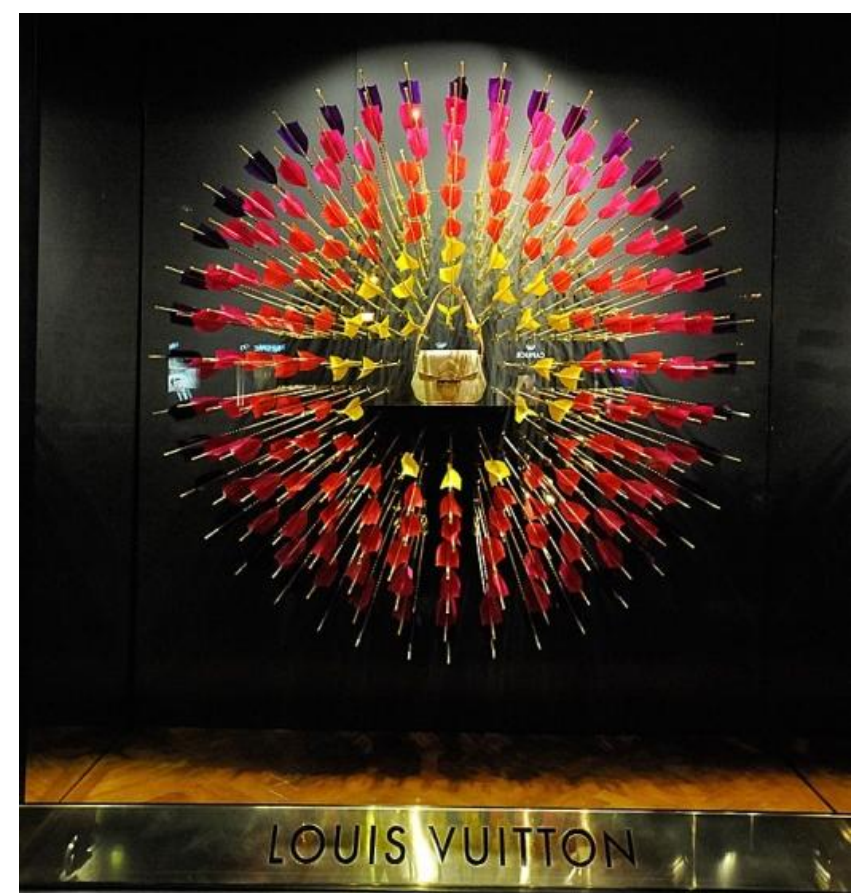

O equilíbrio da vitrine pode ainda ser alcançado através de uma composição assimétrica (Figura 92). Este tipo de composição ocorre quando há a distribuição desigual dos elementos em ambos os lados de um eixo central. Os produtos podem ser de diferentes tamanhos, formas, gerando uma composição mais dinâmica, de maior liberdade e, segundo Lourenço e Sam (2011,) mais próximos dos padrões estéticos contemporâneos.

Figura 92.

Vitrine assimétrica da loja Mara Mac em Belo Horizonte

(2012)

Fonte:

http://www.maramac.com.br /blog/inverno-2012-vitrinesmara-mac

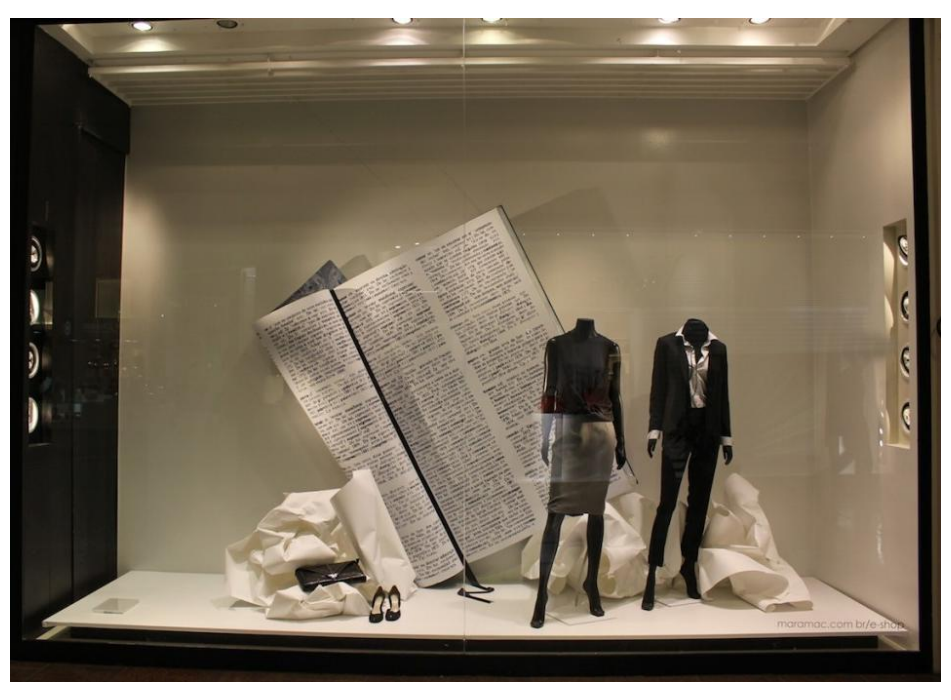

Para alcançar composições harmoniosas através da assimetria é necessário equilibrar elementos diferentes que possuam o mesmo peso ótico, para que se busque uma unidade e estes não concorram entre si. 
O segundo princípio básico que regem uma boa composição é o ritmo, que se dá pela relação entre a forma, a linha e a cor. O ritmo produz efeitos de movimento na encenação da vitrina, de modo a torná-la dinâmica e harmoniosamente atraente (Figura 93). Os elementos são dispostos em intervalos iguais ou alternados, desde que respeitem uma sequência de movimento.

Figura 93. Ritmo da vitrine da loja Louis Vuitton, proveniente da disposição para cima e para baixo dos expositores. Fonte: Elaborada pela autora com base em foto [https://picomeanslittle.com/ blog/2015/10/15/louisvuitton-windows/]

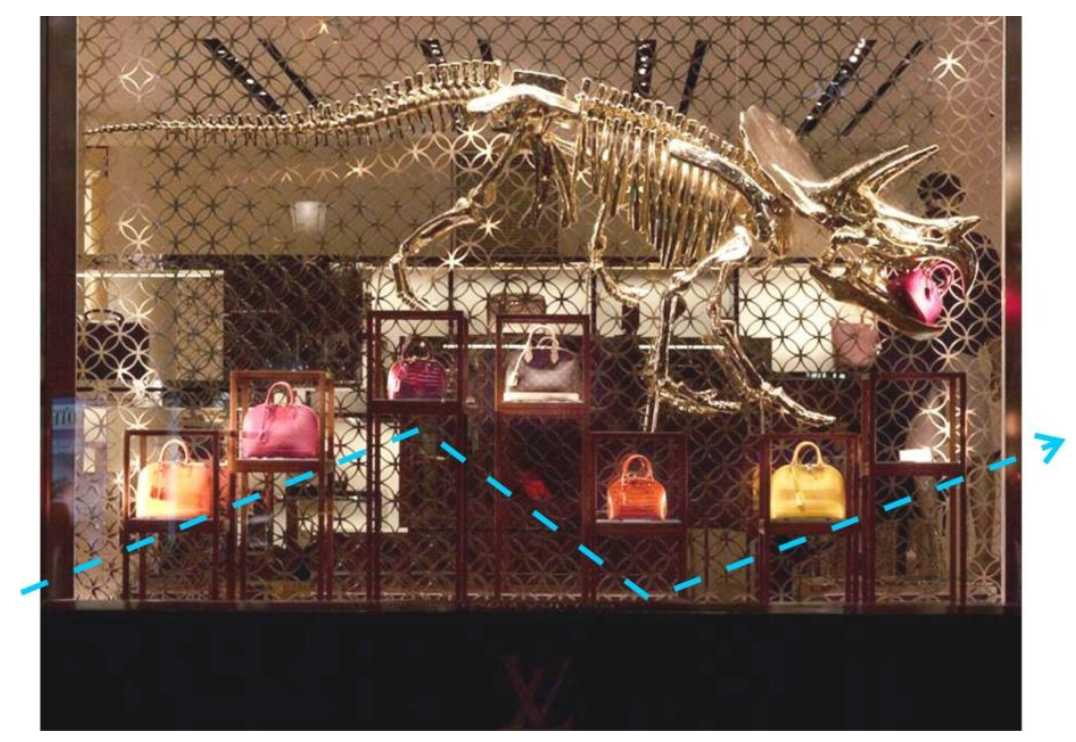

O ritmo também pode ser alcançado também através da repetição. Quando esta é aplicada na vitrina pode reiterar os elementos decorativos, suportes, cores e, sobretudo, os produtos expostos.

A repetição trabalha com uma sequência de elementos em intervalos de espaços iguais. A composição se repete por toda a vitrine (Figura 94 e Figura 95). Não se trata da repetição de produtos idênticos, mas da repetição da técnica de exposição, variando quanto à forma, ao tamanho ou até mesmo aos produtos, desde que sejam respeitados os espaços. 
Figura 94.

Vitrine da Louis Vuitton trabalha com a repetição de gaiolas

Fonte: https://br.pinterest.com/dad aniela/vidrieras-shop/

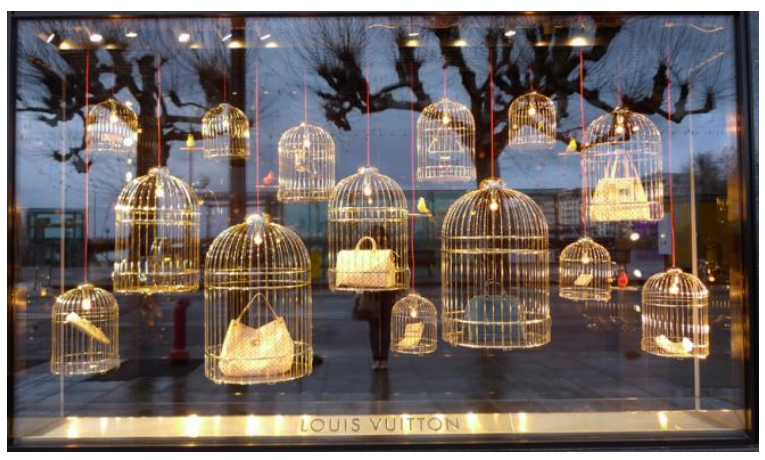

Figura 95. Vitrine da loja Chloé expõe uma sequencia repetida de manequins suspensos. Fonte: https://br.pinterest.com/ Eriksmitharts/retail-storedesign/

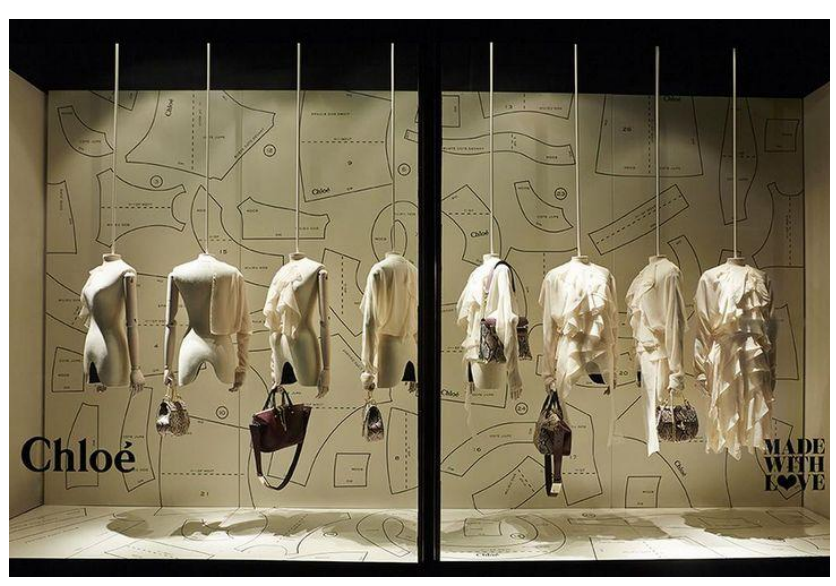

Por fim é possível através da combinação dos elementos da sintaxe visual estabelecer decisivas composições de vitrinas. Fazem parte destes elementos as linhas e formas, que auxiliam a exposição dos produtos de forma mais organizada e eficiente.

A linha é uma sucessão de pontos e pode transmitir a sensação de um espaço maior ou menor do que realmente é, acolhedor ou dinâmico. Como a linha, um elemento determinante, que, apesar de sua simplicidade, se apresenta repleta de significado, pois, além disso, indica direção, comprimento e movimento. As linhas verticais (Figura 96) transmitem sensação de força, altivez e luxo; linhas finas são elegantes e refinadas; linhas horizontais (Figura 97) transmitem calma, estabilidade e tranquilidade; linhas curvas (Figura 98) são graciosas e femininas e sugerem fluidez; as diagonais (Figura 99) tem ritmo, força, dinamismo e ação. Quando combinadas, as linhas, as formas e as cores dominam a direção do olhar do consumidor para os produtos apresentados. 
Figura 96. Vitrine com linhas verticais $d a$ loja Harvey Nichols . Fonte: https://br.pinterest.com/pin/ 564849978238624987/

Figura 97. Vitrine com linha horizontal da loja Bergdorf Goodman

Fonte: https://br.pinterest.com/pin/ 13510867606794050/

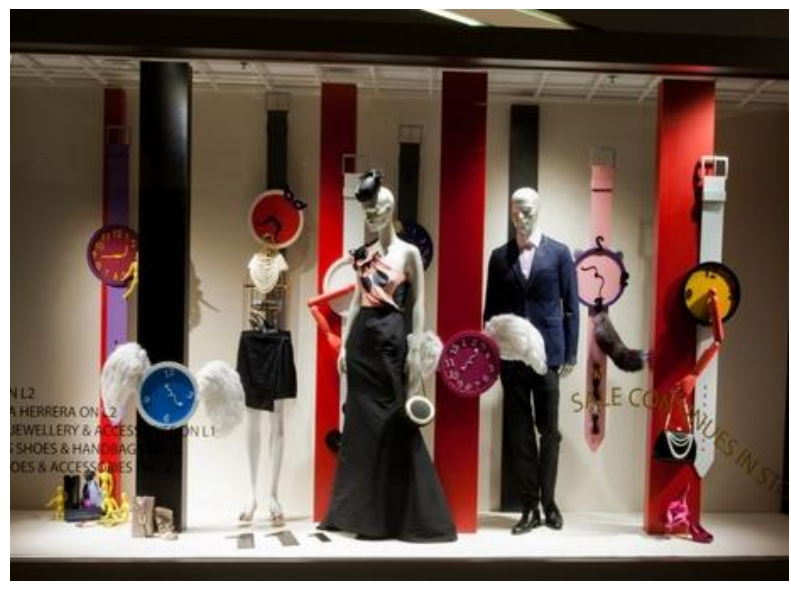

Figura 98.

Vitrine com linhas curvas da loja Nike Fonte: http://www.arch2o.com/inte ractive-display-windows-nike/
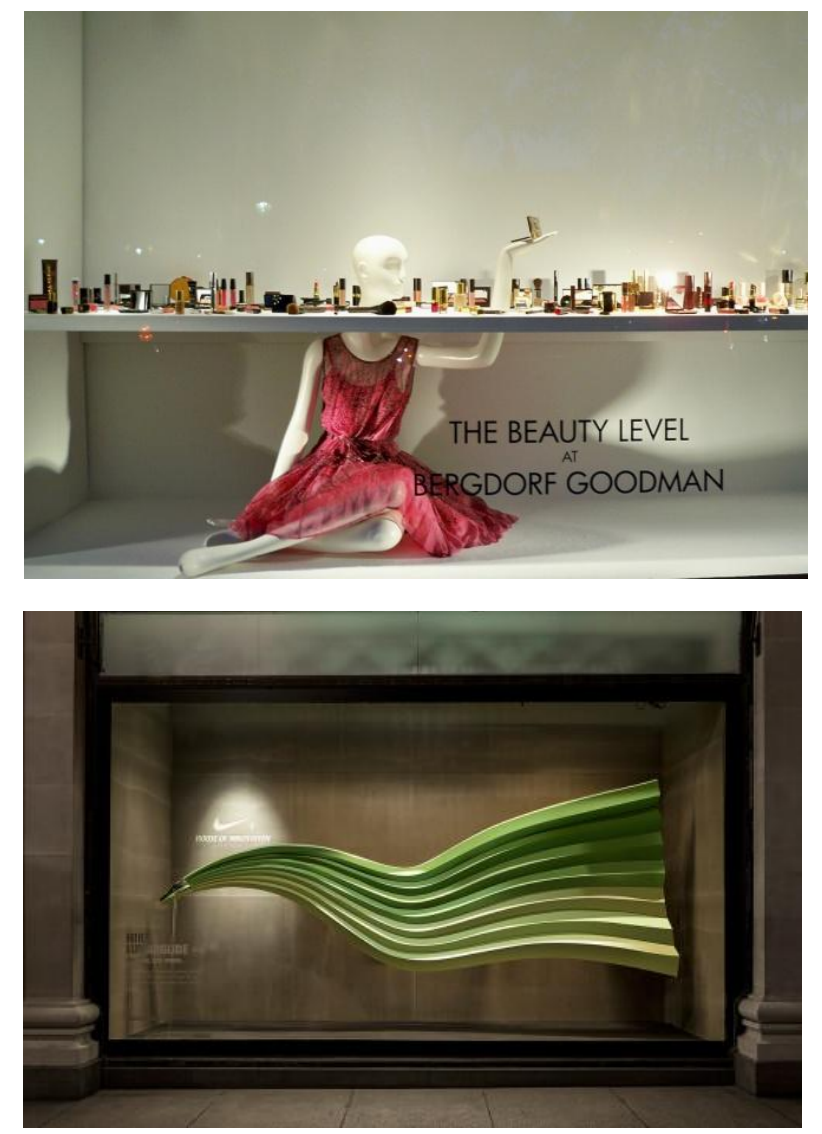

Figura 99. Vitrine com linhas diagonais da loja Gucci Fonte: http://gleicesilvadesigner.blo gspot.com.br/

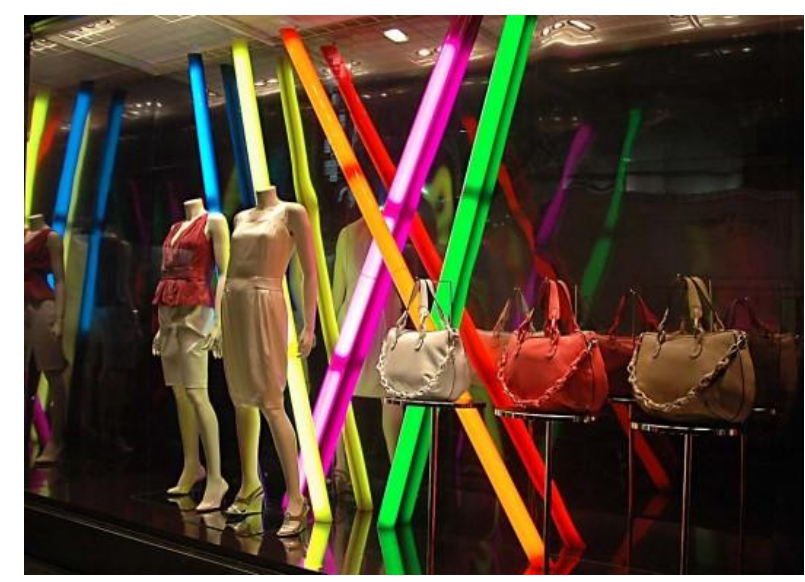


A partir do somatório das linhas, temos as formas, que se consistem na interação entre o objeto principal (produto) e os outros elementos de composição. Praticamente todas as formas da natureza podem ser deduzidas a esquemas geométricos, que irão refletir sensações.

Por meio das formas, induzimos o olhar do cliente. A forma faz com que ao se planejar a vitrine se preocupe com o detalhe sem perder a noção do conjunto. Diferentes formas podem ser utilizadas na composição das vitrines. Os quadrados (Figura 100), por exemplo, ao serem explorados, podem transmitir ao observador conceitos de firmeza, estabilidade, robustez, etc. Já os triângulos (Figura 101), conceitos de elevação, conflito, tensão e até mesmo equilíbrio e estabilidade, ao se optar pelo triângulo equilátero ao invés de outro triângulo que não possui todos os lados iguais.

Figura 100.

O fundo da vitrine é composto por formas retangulares - Loja Peek \& Clopemburg em Dusseldorf Fonte: http://mulpix.com/instagram /loja_em_moda_atacado.ht

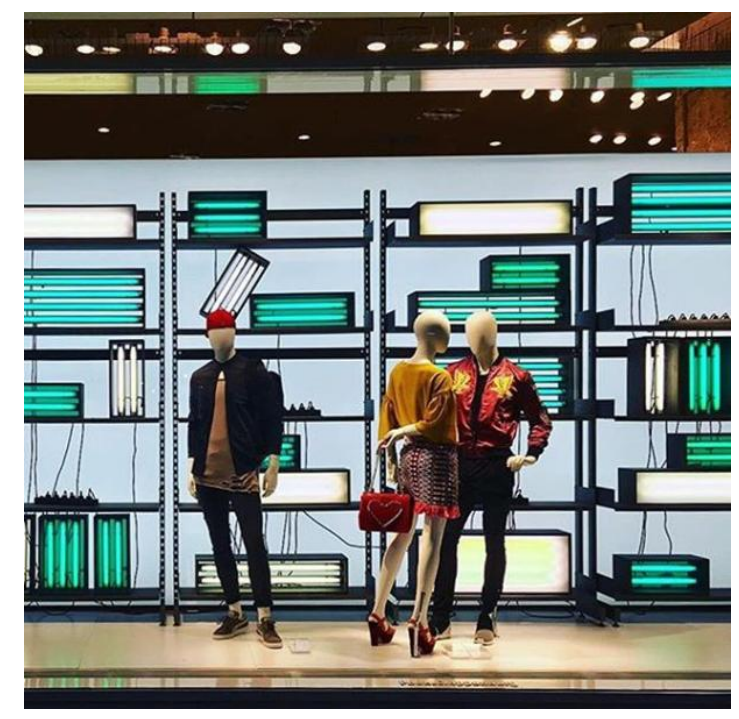

Figura 101. Os elementos da vitrine $d a$ loja da Louis Vuitton formam um triângulo Fonte: https://www.flickr.com/phot os/64210496@NO2/

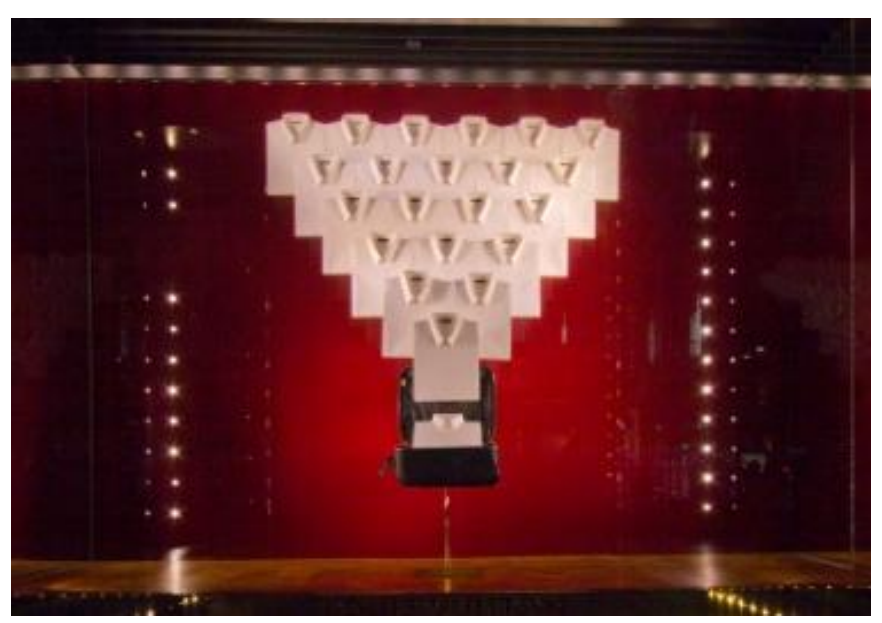


O conhecimento das sensações transmitidas pelas formas e linhas é de fundamental importância, uma vez que assim é possível explorá-las criando valorizações e percursos visuais.

Com estes três princípios básicos de composição expostos neste capítulo é possível explorar novos recursos para organizar as vitrines.

Em composições onde a escala é explorada, por exemplo, os elementos utilizados são representados de forma muito reduzida (Figura 102) ou agigantada (Figura 103). Estes elementos podem ser desde elementos decorativos até os próprios produtos comercializados. Neste último caso, se evita a confusão entre o que é vendido e o que é decorativo, uma vez que ao aumentar demasiadamente o tamanho do objeto, este passa a ter uma atração visual muito grande, o que pode gerar certa estranheza para o caso de ser apenas elemento decorativo.

Figura 102. Nesta vitrine da Dior é explorado o recurso da escala reduzida Fonte:

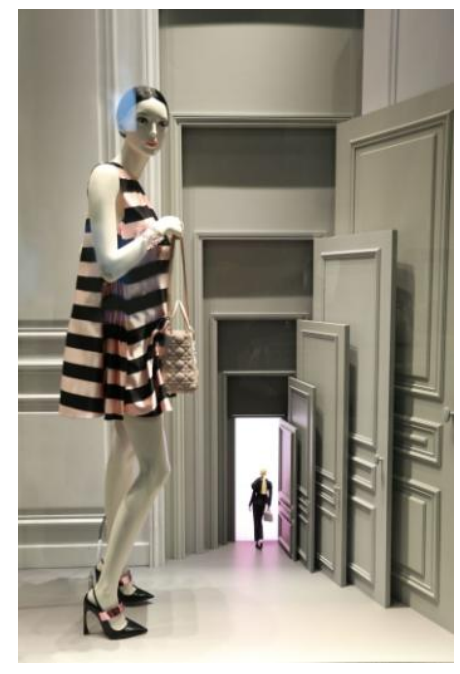

Figura 103. Nesta loja da Chanel, tanto o produto comercializado quando o elemento decorativo estão numa escala maior

Fonte:

https://br.pinterest .com/pin/60306082

487262532

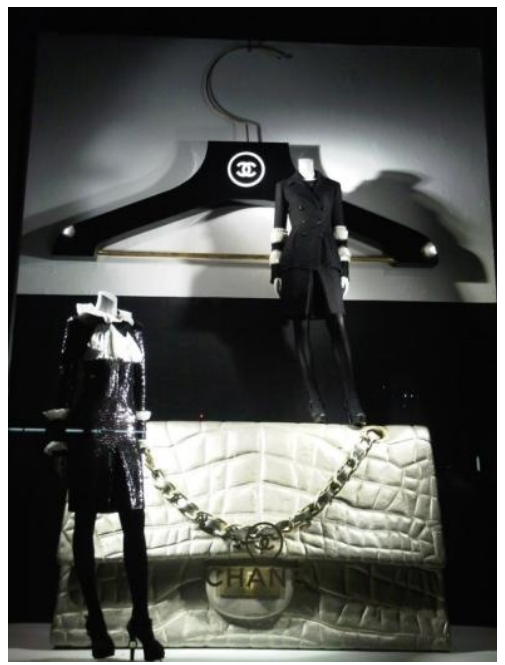

\subsection{EXPOSIÇÃO DE PRODUTOS}

A exposição adequada dos produtos na loja deve ser capaz de encantar o cliente e criar o desejo pela mercadoria, estimulando a decisão da compra. Pela maneira como os produtos são expostos, podemos identificar suas características e aplicações principais e a qual público consumidor está destinado. 
Desta forma, uma das diretrizes básicas para a exposição numa vitrine é a relação do campo visual do observador, que é modificado conforme o grau de aproximação do usuário a loja. Segundo a NBR9050 (2015), considerando o alcance visual de uma pessoa em pé, que possui linha dos olhos a 1,45 metros do chão e se encontra a 45 centímetros afastados da vitrine, pode-se dividir em três zonas de exposição: ruim, boa e regular (Figura 104).

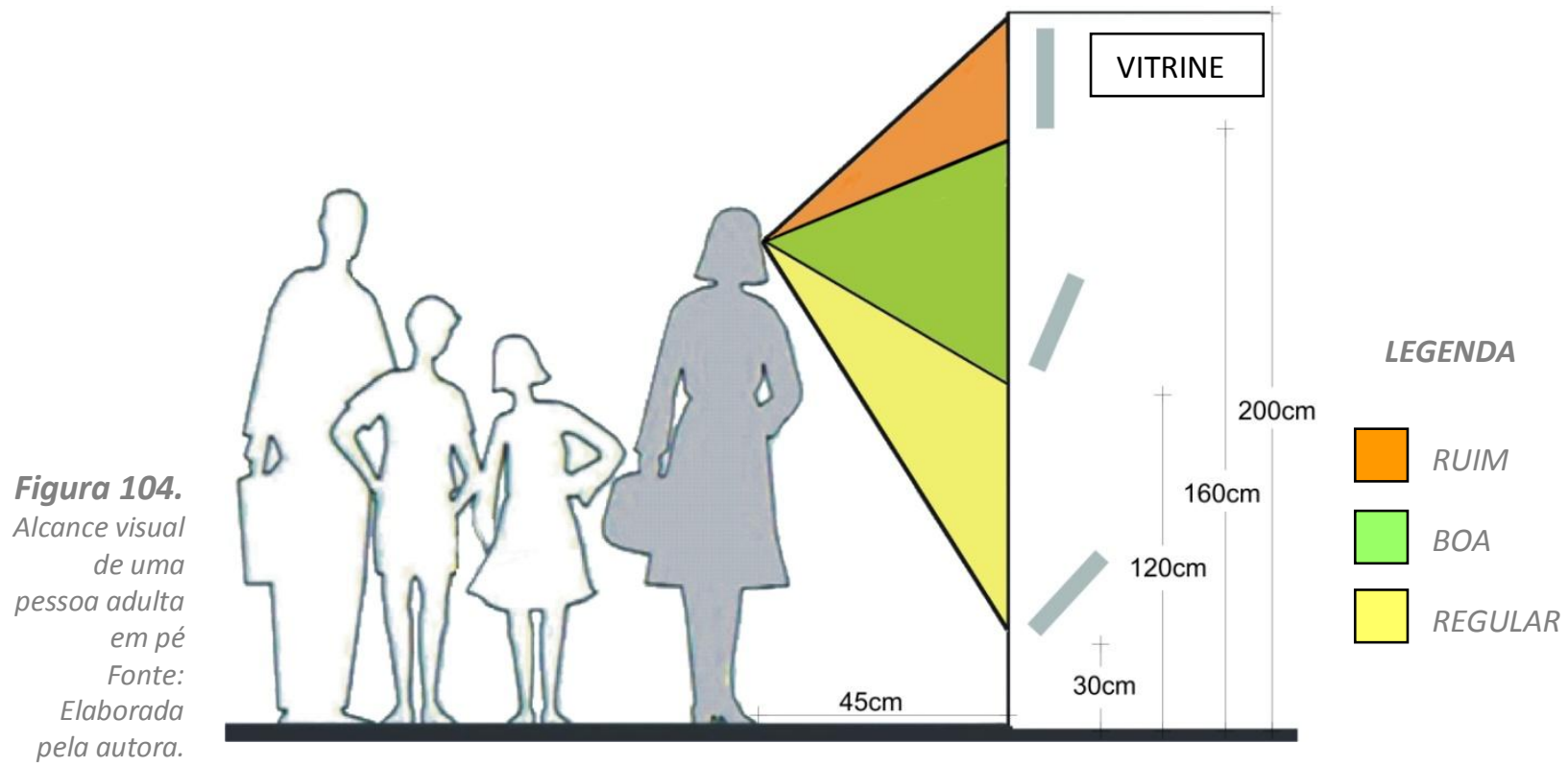

Neste exemplo, a zona ruim para exposição está localizada numa faixa de altura que varia entre 1,60 metros do chão a 2,00 metros, sendo este 0 limite máximo da visão do observador a esta distância. A zona considerada boa para exposição está entre 1,20 metros a 1,60 metros, enquanto a zona regular encontra-se abaixo desta faixa, variando de 0,30 metros do chão a 1,20 metros.

Obviamente, que a zona de exposição mais favorável vai depender significativamente da altura do observador. No caso do observador ser uma criança ou um cadeirante (Figura 105), por exemplo, esta altura irá ser reduzida consideravelmente. 
Figura 105.

Cones visuais da pessoa em cadeira de rodas Fonte: NBR9050, 2015.

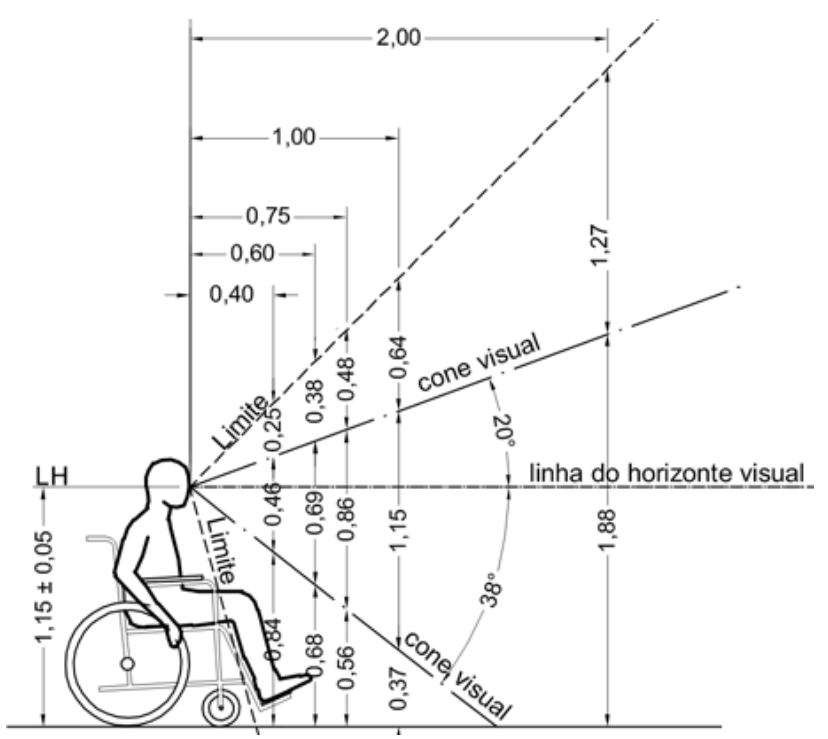

Considerando a mesma situação apresentada na Figura 105, onde o observador encontra-se a 45 centímetros da vitrine, um cadeirante teria um alcance visual muito menor. Seu limite superior de visão seria de um pouco mais de 1,50 metros e sua zona favorável de visualização estaria compreendida entre 0,85 metros e 1,30 metros.

Além disso, a distância que o usuário encontra-se da vitrine é outro fator decisivo para se calcular o alcance visual, pois quanto mais distante este estiver, maior será seu cone visual. A uma distância de um metro da vitrine, por exemplo, o limite superior do alcance visual de uma pessoa adulta em pé aumentará para cerca de 2,65 metros e a zona de exposição mais favorável estará compreendida entre 1,91 metros e 0,87 metros do piso.

A zona de exposição mais favorável é onde está localizado o ponto focal do usuário, ou seja, o local de maior atração e visibilidade do produto. Quanto mais importante for o produto, mais próximo a esta zona ele deve estar.

A distância que o usuário encontra-se da vitrine também interfere na largura do alcance visual. De acordo com a NBR9050 (2015), no plano horizontal o limite para movimentação da cabeça é 60 graus, enquanto o limite de movimentação dos olhos é de apenas 30 graus. Devido a isso, a uma distância de 45 centímetros da vitrine a largura máxima de visualização, considerando o movimento máximo possível da cabeça seria de um pouco mais de 1,50 metros (Figura 106). 


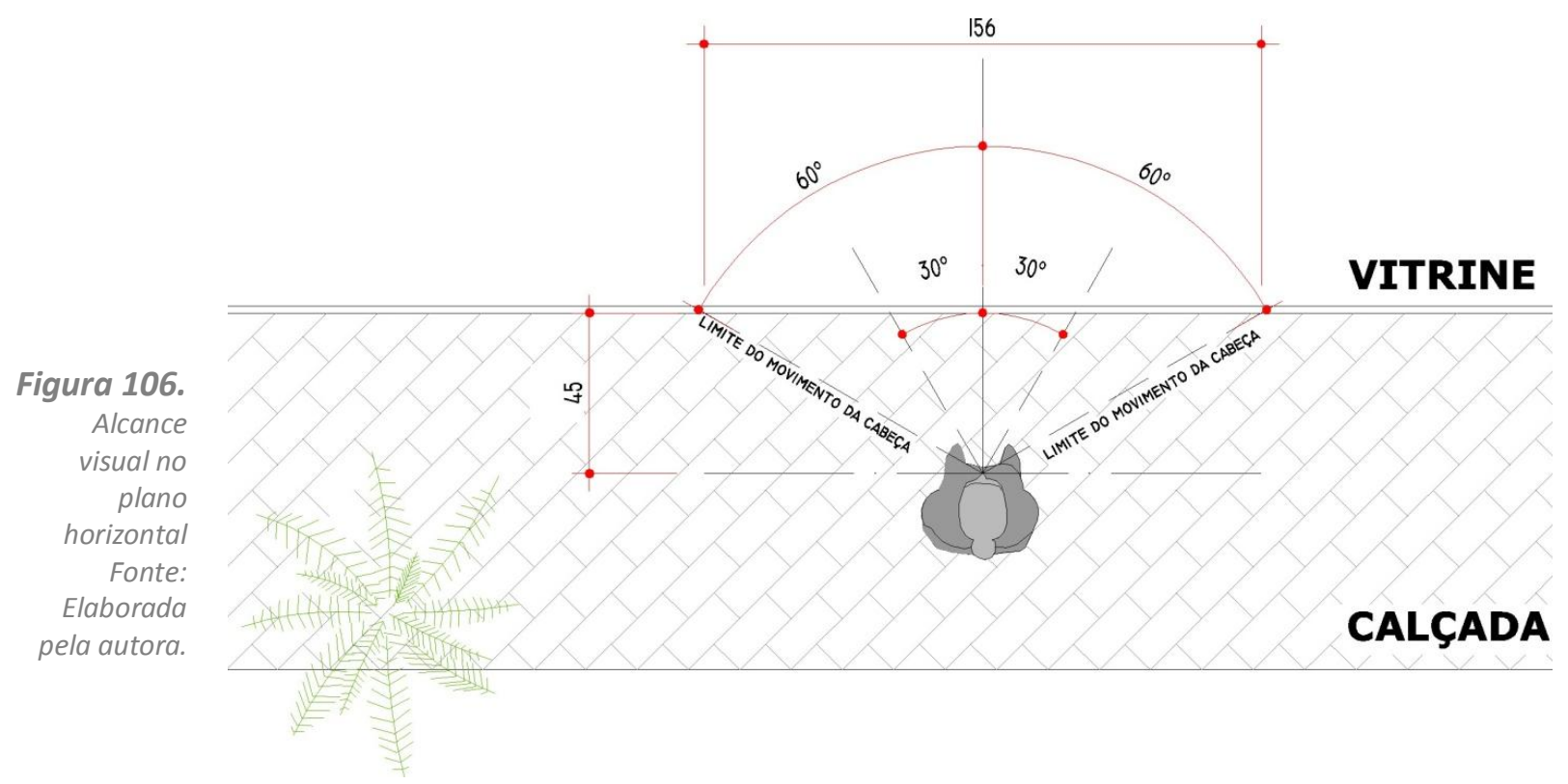

Porém, todas estas considerações do alcance visual são considerando o usuário estático, mas quando visualizamos o comportamento do consumidor, vemos que na maior parte das vezes esta observação acaba ocorrendo ao longo do seu caminhar. Por isso Basso (2008) explicita esta mudança gradativa do ponto focal conforme a movimentação do usuário, estabelecendo porcentagens de atenção para as zonas da vitrine (Figura 107).

Figura 107. Nível de percepção do usuário ao longo da vitrine Fonte: Elabora pela autora com base em BASSO, 2008.

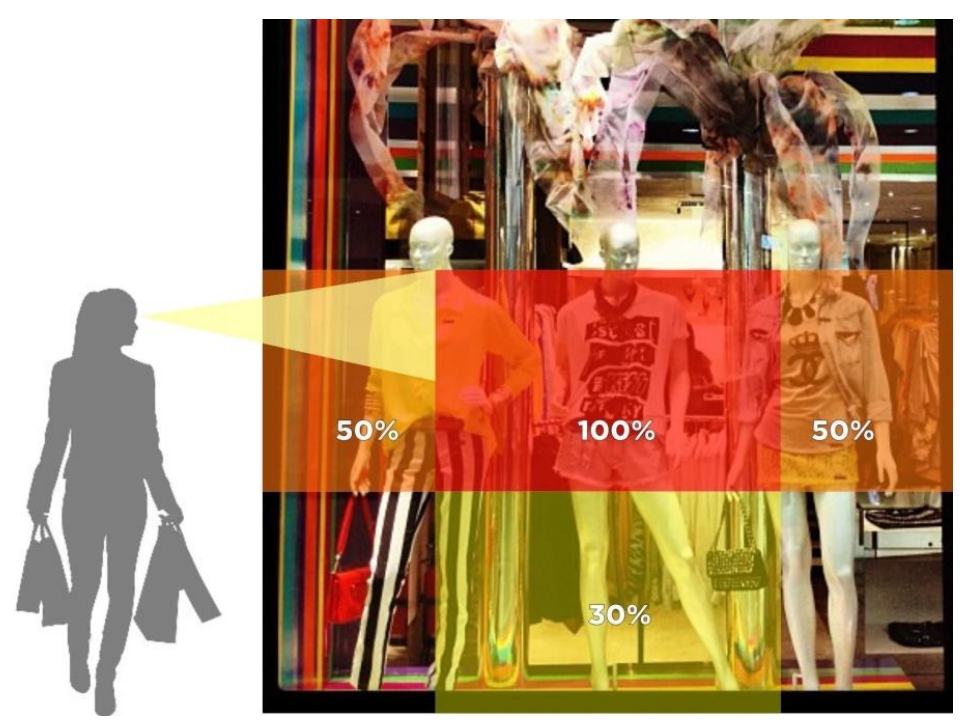

Já o caminho visual é o percurso pelo qual a visão do consumidor faz ao observar a vitrine. Segundo Basso (2008), o usuário ocidental faz uma leitura visual da esquerda para a direita e de cima para baixo (Figura 108). 
Esse procedimento coincide com o padrão de movimentação e visualização no interior da loja (UNDERHILL, 2009).

Figura 108. Caminho visual feito pelo observador Fonte: Elabora pela autora com base em BASSO, 2008.

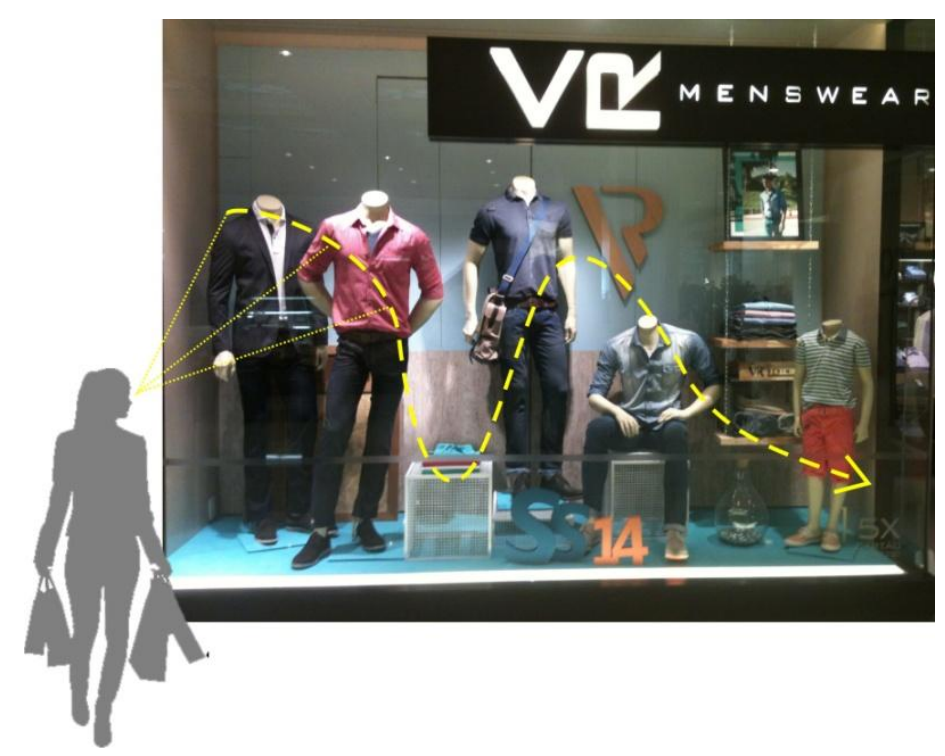

\subsection{ILUMINAÇÃO}

A iluminação desempenha um papel de destaque em uma vitrine. As luzes criam e destacam as peças que compõem a vitrine. Pode ser um dos elementos estruturadores da ambientação, sendo importante para o desenvolvimento do partido arquitetônico, conceito da loja e gestão da marca. Por isso, a importância de se escolher o tipo de iluminação adequada, pois caso isso não ocorra, pode-se alterar não só a percepção do produto, como de toda a composição.

Existem dois tipos de iluminação: a indireta, que faz parte do projeto geral de iluminação da loja, ou seja, a iluminação do teto, e a direta, que desempenha a função de destacar determinado objeto.

A iluminação indireta é feita normalmente com lâmpadas fluorescentes, já que é uma luz de baixo consumo para iluminação do ambiente geral. Este tipo de iluminação não pode ser exaustiva nem muito fraca. 
A iluminação direta deve ser direcionada cuidadosamente para que o foco incida diretamente sobre os produtos que desejam serem destacados com o cuidado de ao utilizar lâmpadas incandescentes, não aproximar estas demasiadamente dos produtos, para que estes não sejam queimados ou danificados. Além disso, deve-se evitar a iluminação direta contra o vidro, pois, além de gerar reflexo, pode trazer incômodo ao consumidor.

Além disso, a observação de alguns conceitos luminotécnicos se torna necessário para que se possa quantificar e qualificar a iluminação em um ambiente comercial.

Um destes conceitos é a temperatura de cor, que medida em Kelvin (K), expressa a aparência da cor da luz emitida pela fonte de luz. Quanto mais alta a temperatura de cor, mais branca, ou seja, clara, é a tonalidade da cor da luz. Desta forma, classifica-se a cor da luz em quentes ou frias (Figura 109), de acordo com a sensação visual e psicológica da luz no ambiente.

Figura 109. Variação da tonalidade da luz conforme de temperatura de cor

Fonte:

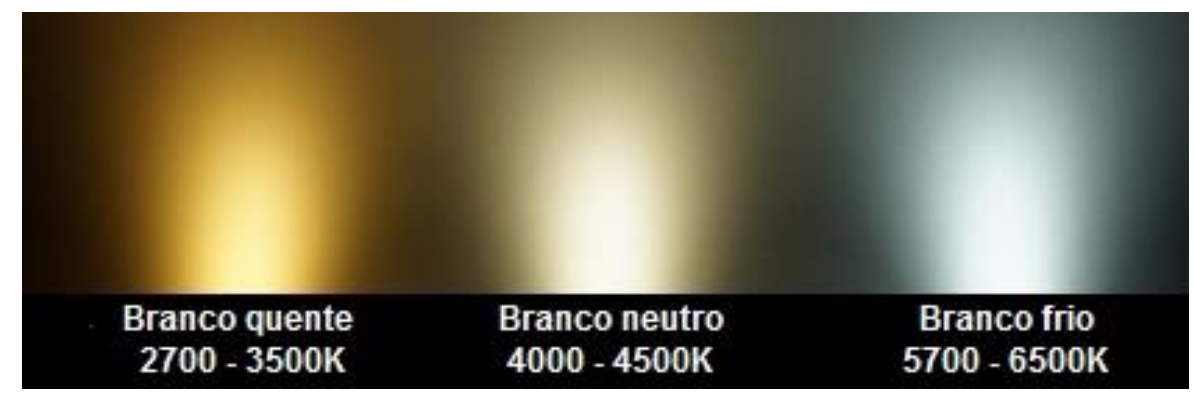

A luz quente (Figura 110) é a que possui uma aparência amarelada e temperatura de cor baixa, 3.000k ou menos. Esta tonalidade propicia ambientes mais aconchegantes e relaxantes. Já a luz fria (Figura 111) possui aparência muito branca, chegando até o azul violeta, com temperaturas de cor elevadas $6.000 \mathrm{k}$ ou mais. Esta luz é mais estimulante, ideais para ambientes de trabalho. 
Figura 110.

Iluminação quente na loja

Farm

Fonte: Acervo pessoal da autora.

Figura 111.

Iluminação fria da loja Schutz

Fonte: Acervo pessoal da

autora.
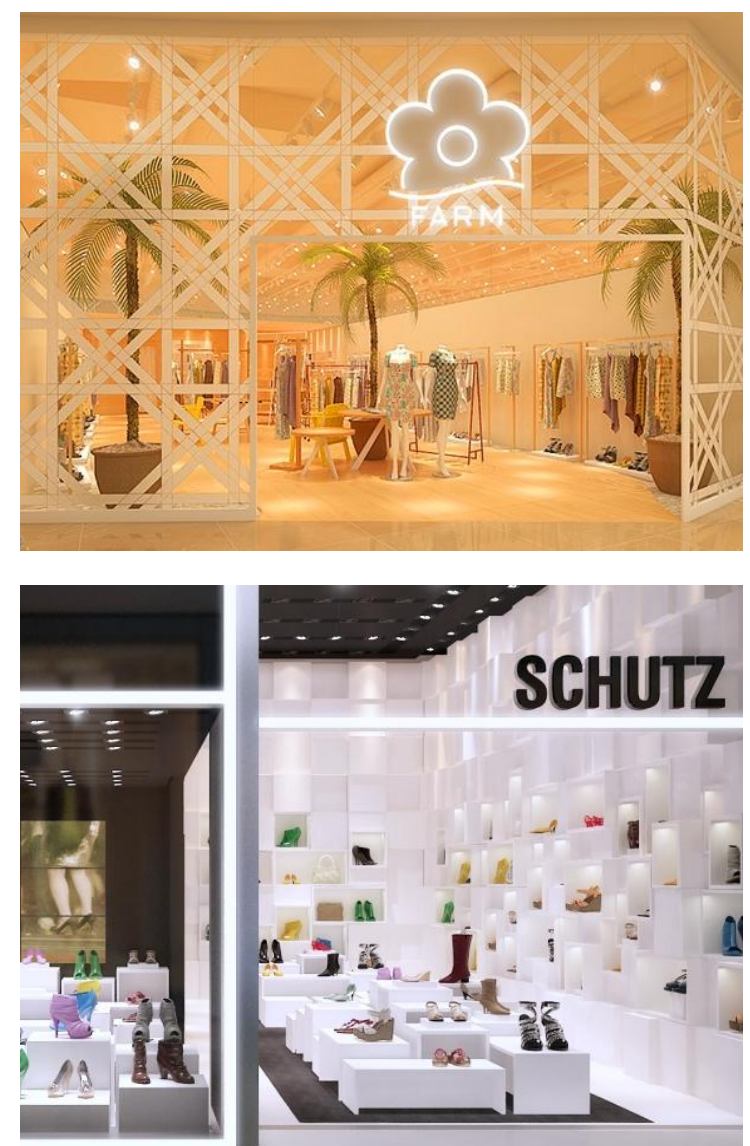

Outro conceito importante é o índice de reprodução de cor. Este índice quantifica a fidelidade com que as cores são reproduzidas sob uma determinada fonte de luz (Tabela 4).

No ambiente comercial, como um todo, deve-se optar pela utilização de lâmpadas com um alto índice de reprodução de cor, para que as cores dos produtos não distorçam.

Tabela 4. Índice de Reprodução de Cores e exemplos de aplicação

\begin{tabular}{|c|c|c|c|}
\hline Classificação & Nível & IRC & Exemplos de Aplicação \\
\hline Excelente & \multirow{2}{*}{ Nível 1} & 1a Ra 90-100 & \multirow[t]{2}{*}{ Testes de cor, floricultura, escritórios, residências, lojas } \\
\hline Muito bom & & 1b Ra 80-89 & \\
\hline Bom & \multirow{2}{*}{ Nível 2} & 2a Ra 70-79 & \multirow[t]{2}{*}{ Área de circulação, escadas, oficinas, ginásios esportivos } \\
\hline Razoável & & 2b Ra 60-69 & \\
\hline Regular & Nível 3 & Ra 40-59 & $\begin{array}{l}\text { Depósitos, postos de gasolina, pátio de montagem } \\
\text { industrial }\end{array}$ \\
\hline Insuficiente & Nível 4 & Ra 20-39 & Vias de tráfego, canteiro de obras, estacionamentos \\
\hline
\end{tabular}


Diferente do que o senso comum acredita, a capacidade das lâmpadas de reproduzirem bem as cores - IRC (Figura 112) não está ligada a sua temperatura de cor (K). Existem lâmpadas com diferentes temperaturas de cor e que apresentam o mesmo IRC.

Figura 112.

Lâmpadas com diferentes IRC: Baixo IRC (foto esquerda) $X$ Alto IRC (foto direita) Fonte: http://www.npled.com.br/pa gina/conceitosluminotecnicos.html
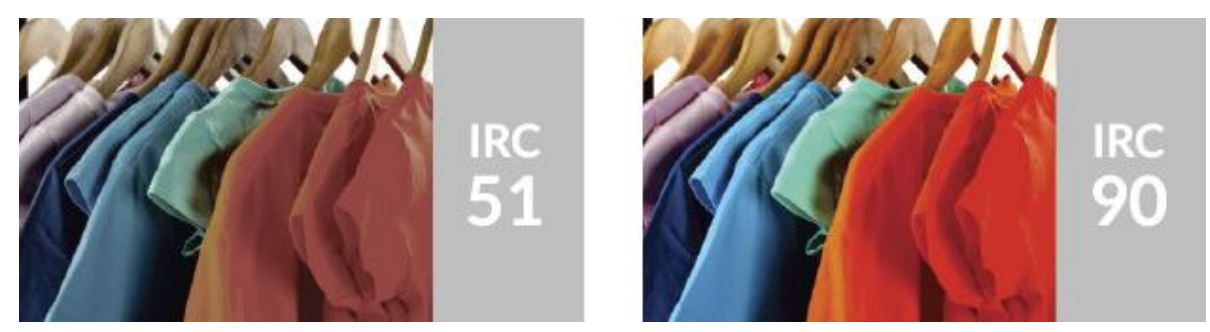

O último conceito a ser abordado é a iluminância, que é a quantidade de luz ou fluxo luminoso que atinge uma unidade de área de uma superfície por segundo. A unidade de medida é o lux, cujo símbolo é "IX".

Segundo a NBR 5413/1992, que rege sobre a lluminância de interiores, para se quantificar o nível de iluminação, deve ser considerado a idade do observador e características da tarefa a ser executada neste ambiente, como velocidade, precisão e refletância do fundo. Tendo em vista estes aspectos, a Norma indica três opções de níveis de iluminância para lojas:

Tabela 5. Nível de lluminância para Lojas

\begin{tabular}{|c|c|c|c|c|}
\hline Local & Tipo & $\begin{array}{l}\text { Nivel } 1 \\
\text { (|x) }\end{array}$ & $\begin{array}{l}\text { Nivel } 2 \\
\text { (Ix) }\end{array}$ & Nível $3(\mid x)$ \\
\hline \multirow{2}{*}{$\begin{array}{l}\text { Vitrinas e balcões (centros } \\
\text { comerciais de grandes } \\
\text { cidades) }\end{array}$} & Geral & 750 & 1000 & 1500 \\
\hline & $\begin{array}{l}\text { Iluminância suplementar com facho } \\
\text { concentrado }\end{array}$ & 3000 & 5000 & 7500 \\
\hline \multirow{2}{*}{$\begin{array}{l}\text { Vitrinas e balcões (outros } \\
\text { locais fora dos centros } \\
\text { comerciais) }\end{array}$} & Geral & 300 & 500 & 750 \\
\hline & $\begin{array}{l}\text { Iluminância suplementar com facho } \\
\text { concentrado }\end{array}$ & 1000 & 1500 & 2000 \\
\hline \multirow[t]{2}{*}{ Interior de: } & $\begin{array}{l}\text { Lojas de artigos diversos e centros } \\
\text { comerciais }\end{array}$ & 300 & 500 & 750 \\
\hline & Outros locais & 300 & 300 & 750 \\
\hline
\end{tabular}




\subsection{O USO DA COR}

A cor é mais que um elemento de decoração e para Mestriner (2002, p. 53), "constitui-se num elemento de comunicação, provocando estímulo visual como nenhum outro elemento". A cor interfere no modo como são hierarquizadas as informações, pode induzir a determinados comportamentos e, sobretudo, influencia o entendimento que o cliente tem sobre o estabelecimento.

Ao escolher a palheta de cores de um ambiente comercial, se deve buscar realizar uma escolha consciente baseada na gestão da marca, no conceito da loja e nas associações psicológicas pertinentes a cada cor. Da mesma forma, Farina et al. (2011) compartilham deste pensamento:

Com referência às áreas publicitárias e de promoção de vendas, vários fatores se conjugam para determinar a cor exata que será a portadora da expressividade mais conveniente a cada tipo específico de mensagem para um produto a ser consumido ou serviço a ser utilizado. $\mathrm{Na}$ realidade, a especificidade daquilo que será anunciado tem íntima conexão com a cor empregada, quer seja para transmitir a sensação de realidade, quer para causar impacto ou realçar um diferencial. (FARINA et al., 2011, p. 116).

As cores acarretam associações psicológicas, ligadas intimamente ao filtro cultural de cada sociedade. Por isso, torna-se muito difícil universalizar um significado cultural e psicológico para cada matiz, sendo possível apenas estipular associações inerentes a nossa sociedade.

No Brasil, por exemplo, em casamentos é costume das noivas usarem vestidos brancos, em sinal de pureza e castidade, enquanto na antiga Pomerânia ${ }^{11}$, as noivas tradicionalmente se casavam de preto. Se para a nossa tradição o vestido preto é sinal de luto ou objeto de mau agouro, na antiga Pomerânia o seu uso era uma questão de identidade (VILELA, 2006). Já na índia, até hoje as noivas costumam usar vermelho e não branco, pois para eles o branco é que tem significado de morte e maus presságio.

\footnotetext{
${ }^{11}$ Região situada na faixa costeira junto ao mar Báltico, onde hoje está a fronteira entre a Alemanha e a Polônia.
} 
Portanto as combinações devem ser criteriosas, tanto na aplicação dos produtos quanto na estruturação do ambiente. Isso porque, as cores tem o poder de criar dissimulações espaciais, que podem ser exploradas, como sensações de amplitude ou redução de espaço, além de serem grandes responsáveis pelo equilíbrio. De acordo com Crepaldi (2006):

Este grau de proximidade ou distância depende de vários fatores, como a iluminação e a saturação. As cores quentes (vermelhos, amarelo, laranja) parecem nos dar sensações de proximidade, calor, densidade, opacidade, secura, além de serem estimulantes. Em contraposição, as cores frias (azul, verde) dão a sensação de distância, mas também são transparentes, úmidas, aéreas, leves $e$ acalmam. (CREPALDI, 2006, pg. 3)

Muitas cores utilizadas na mesma vitrine, sem o uso de nenhum critério de harmonia cromática, normalmente resultam em composições desordenadas, podendo gerar a impressão de uma confusão visual.

Para evitar que isso ocorra é necessário utilizar técnicas de composição cromática, uma vez que são várias as possibilidades de combinações de cores. Estas técnicas fazem uso do círculo cromático (Figura 113), o qual apresenta uma escala de cores, posicionada de forma sequencial em função do seu comprimento de onda.

Figura 113. Círculo Cromático

Fonte:

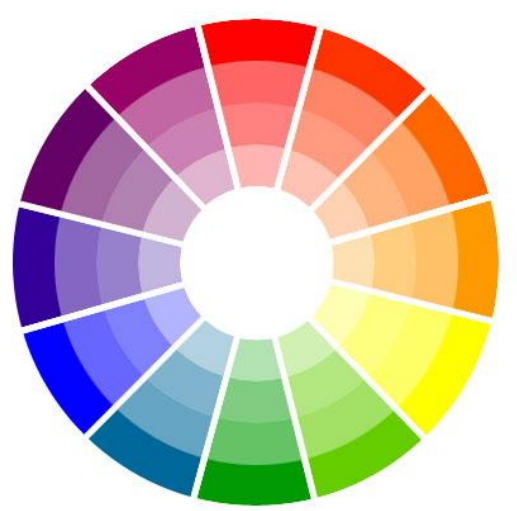

Quando observamos o círculo cromático, pode-se surgir a dúvida do por que o branco e o preto não estão presentes nesta representação. No estudo cromático há duas características a serem estudas: as luzes e os pigmentos. As cores que se percebem são resultantes da existência da luz. O branco é a junção de todos os espectros de cores. É a cor que reflete todos os raios luminosos, não absorvendo nenhum e por isso aparecendo 
como clareza máxima. Já com o preto, ocorre exatamente o oposto. 0 preto é a ausência de cor, pois este absorve todos os raios luminosos, não refletindo nenhum. Por isso, fisicamente, o branco $e$ preto não são considerados cores, mas características da luz, que convencionamos chamar de cor e por tal motivo, não são representadas no círculo cromático.

Independente disso, para este estudo sobre a abordagem dos parâmetros de design visual aplicados a fachadas comerciais, adotou-se o conceito de cor-pigmento, pois este é aquele percebido através das substâncias materiais corantes na presença da luz. Assim, se considerará todas as cores presentes no círculo cromático, juntamente com o preto e branco para analisar os estabelecimentos comerciais.

Com base neste conceito, a harmonia das cores pode ser alcançada através de algumas técnicas. Desta maneira, podemos classificar as composições, no que se referente às cores, em:

- Monocrômica: é utilizada apenas uma cor (Figura 114) como recurso visual. É a maneira mais fácil de estabelecer harmonia no espaço, podendo gerar um impacto altamente positivo, quando bem explorado.
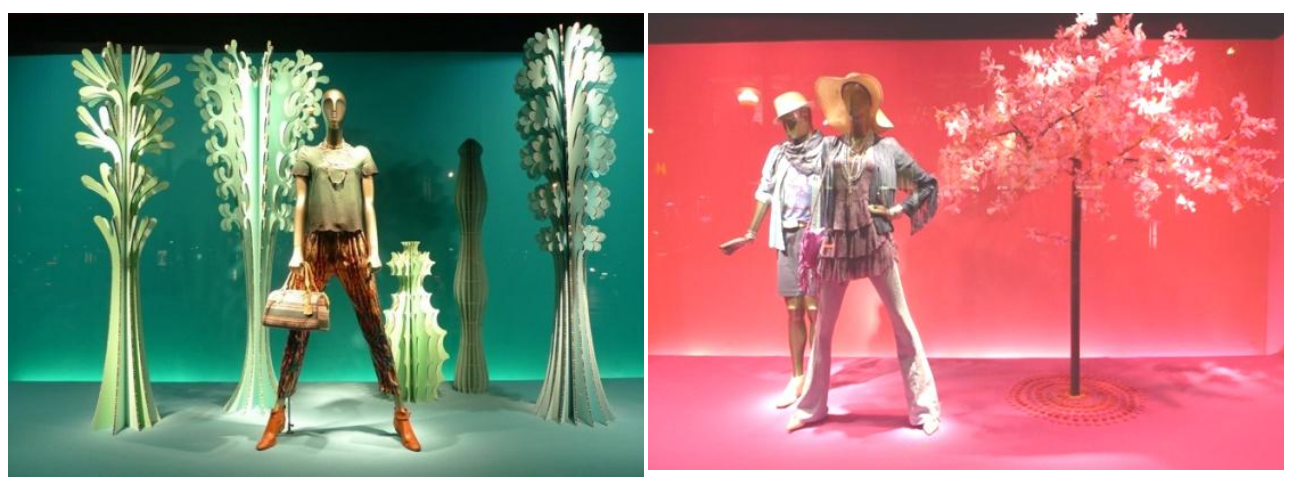

Figura 114. Vitrines monocromáticas da loja Printemps (2011)

Fonte:
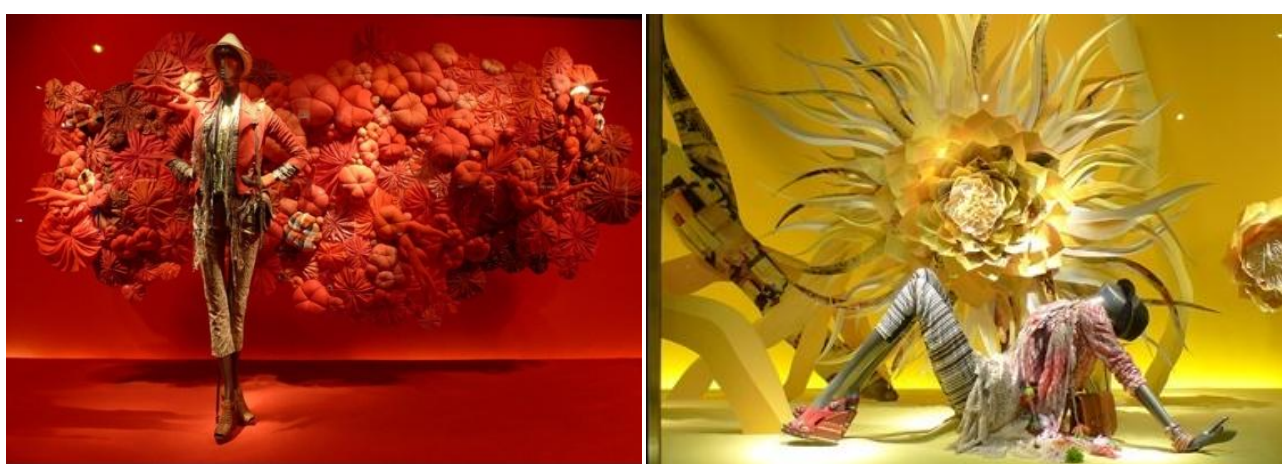
- Análoga: são utilizadas duas ou mais cores sequenciais no círculo cromático (Figura 115) na composição. As cores vizinhas na roda de cores possuem uma boa combinação e criam designs serenos e confortáveis. Esta é uma boa opção, pra quando se pretende expor muitas peças estampadas ou que possuem várias cores. Através da harmonia análoga é possível utilizar a cor predominante destas e agrupá-las, buscando uma ordenação visual.

Figura 115.

Vitrine com harmonia análoga da loja H\&M com fundo em cores análogas

Fonte: Elaborada pela autora com

base em foto [https://www.flickr. $\mathrm{com} /$ photos/journal desvitrines]
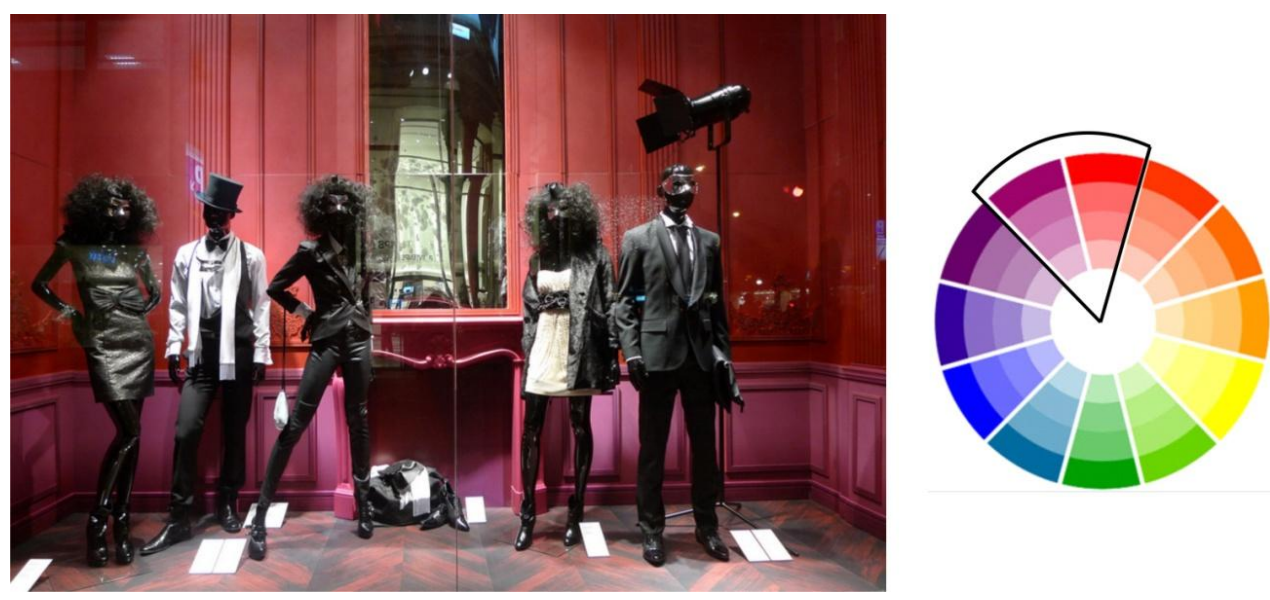

- Complementar: são utilizadas cores diametralmente opostas no círculo cromático (Figura 116), por exemplo, vermelho e verde. 0 alto contraste entre elas cria um visual vibrante, que se harmoniza entre si.

Figura 116.

Vitrine com harmonia complementar da loja United Colors of Benetton (2012) Fonte: Elabora pela autora com base em foto [http://windowdisp/ aybangkok.blogspot .com.br/2012/03/u nited-colors-ofbenetton-centralworld.html]
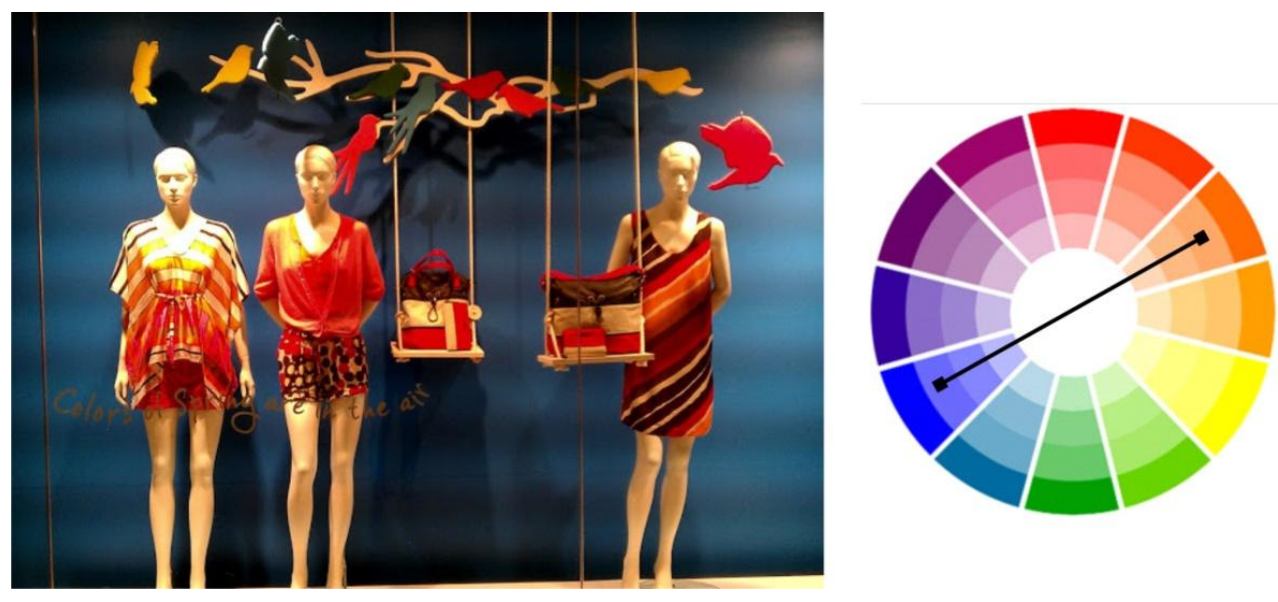
- Triádica: são utilizadas três cores equidistantes no círculo cromático

(Figura 117). Esta composição é usualmente adotada, porque oferece o contraste visual forte ao reter o contrapeso e a riqueza da cor. É considerado mais equilibrado do que o esquema complementar (WALKER, 1995).

Figura 117.

Vitrine com

harmonia triádica Fonte: Elaborada pela autora com base em foto [https://br.pintere st.com/pin/31131 1392969244889]
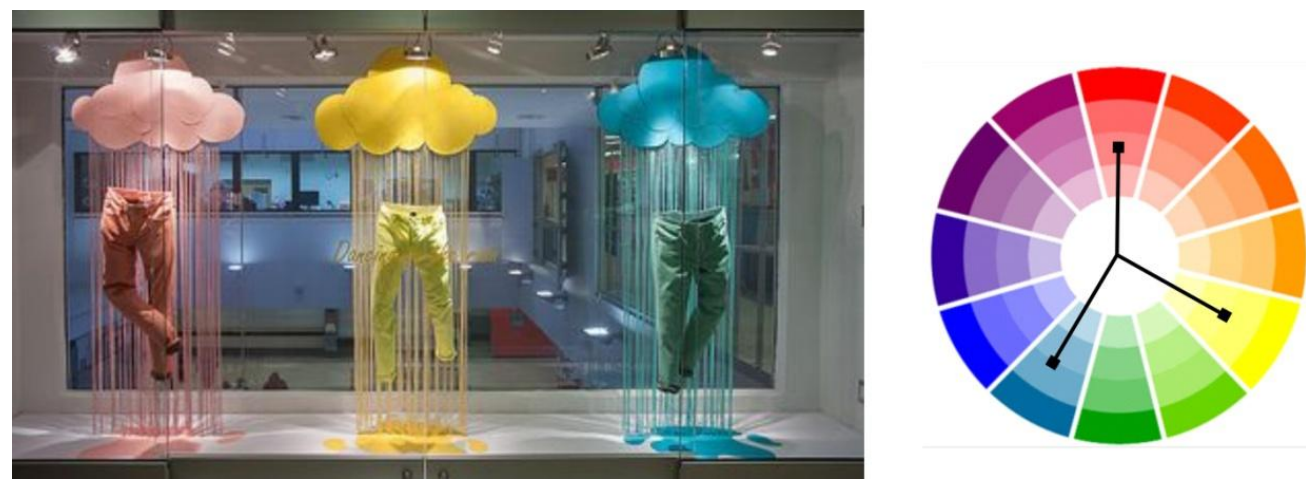

- Acromática: são utilizadas cores neutras, que estão situadas mais próximas ao centro do círculo cromático (Figura 118). Estas cores já não possuem grande quantidade de saturação e, por isso, o matiz original quase não é mais identificado. Composições acromáticas transmitem um ar mais elegante, sóbrio e impessoal.

Figura 118. Vitrine com harmonia acromática da loja Printemps (2010) Fonte: Elaborada pela autora com base em foto [https://br.pintere st.com/pin/32721 4729146061310/]
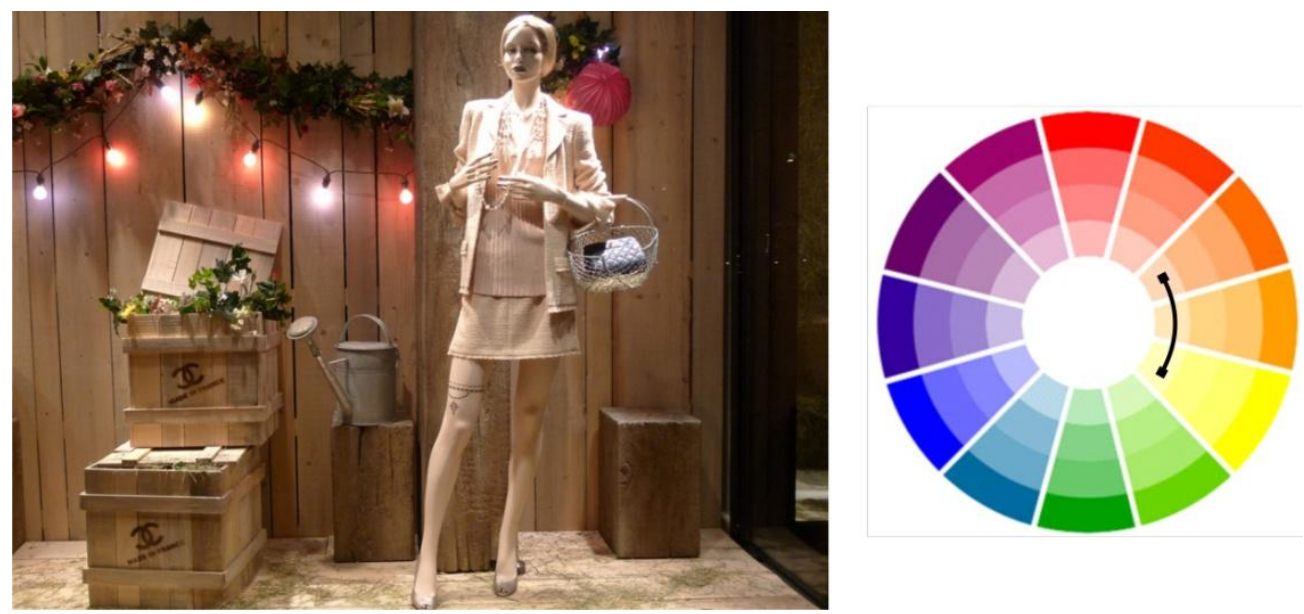
Independe da composição cromática escolhida para a loja, é importante entender os efeitos psicológicos que as cores individualmente geram, uma vez que ao compreender a essência de cada cor, é mais fácil presumir os reflexos sensoriais no consumidor.

As cores agem sobre os sentidos, com maior ou menor intensidade, interferindo nas decisões dos consumidores, podendo estimular a emoção, a consciência e os desejos individuais.

Os aspectos psicológicos da cor (Figura 119) estão diretamente relacionados às questões socioculturais e por tal motivo, serão apresentadas abaixo as principais cores e suas associações dentro da sociedade brasileira.

Figura 119.

Principais aspectos psicológicos associados as
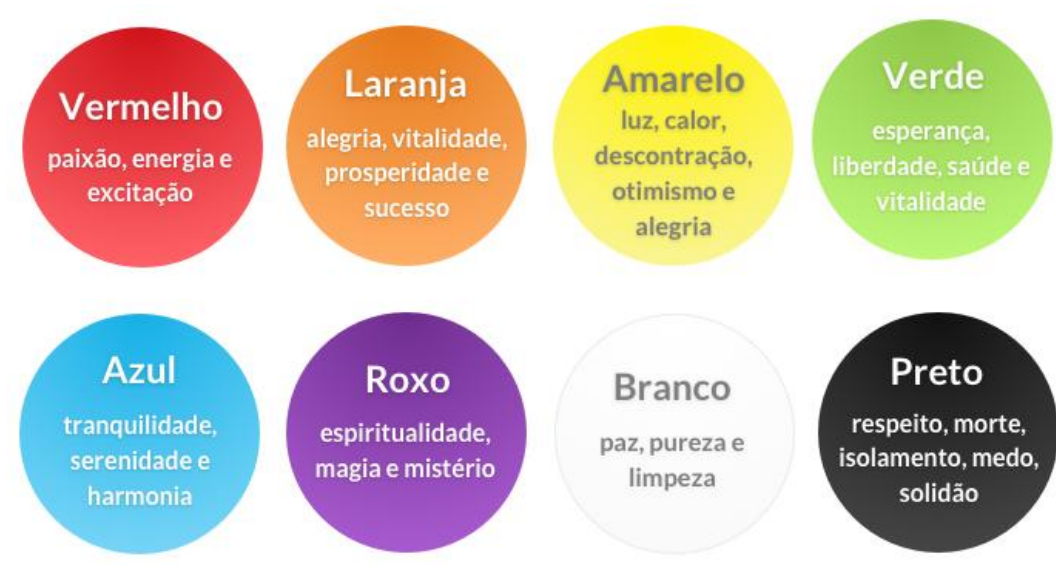
Branco
paz, pureza e limpeza

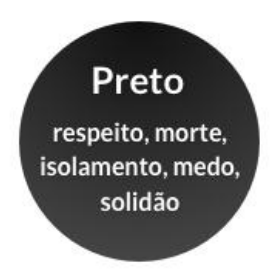

br/cromoterapia/

\subsubsection{BRANCO}

Também chamada de "cor da luz", porque reflete todas as cores do espectro, a cor branca proporciona uma clareza total. O branco indica neutralidade, pureza, vida, símbolo da paz, da espiritualidade, da inocência e da virgindade.

O branco pode ser usado em qualquer ambiente, mas quando não está associado com outras cores, faz com que os espaços se tornem monótonos. Ambientes excessivamente brancos (Figura 120 e Figura 121) causam um cansaço visual, devido ao ofuscamento que pode causar a visão, além de poderem transmitir uma sensação de opressão. 


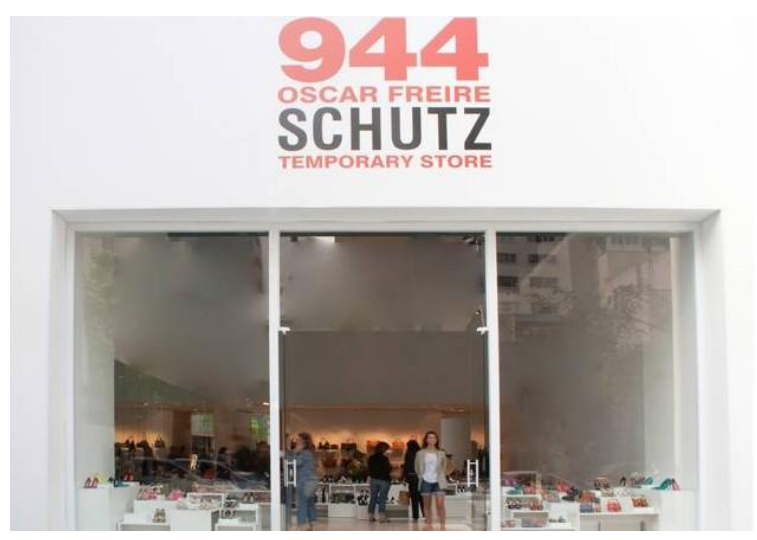

Figura 120. Loja Schutz da Oscar Freire em São Paulo Fonte: http://modarevenda.fashionbubbles.com/

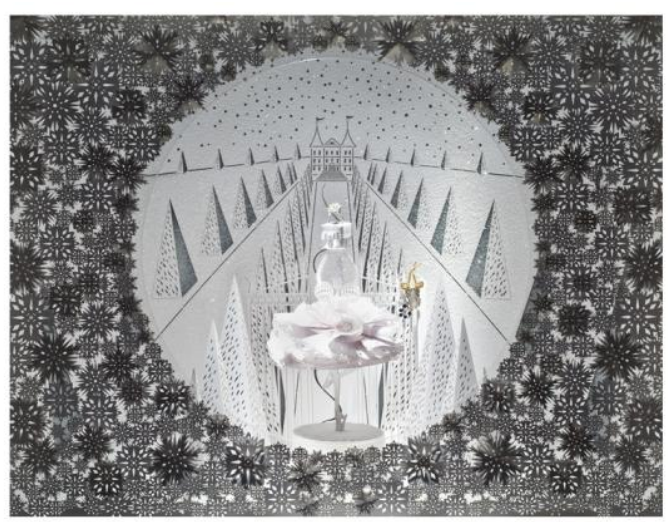

Figura 121. Vitrine da Tiffany \& Co. em New York (2009) Fonte: http://www.zoebradley.com/

\subsubsection{VERMELHO}

Segundo WALKER (1995), o pigmento vermelho aumento do fluxo de sangue, manifestado por aumento da pulsação e respiração mais rápida. Além disso, as papilas gustativas ficam mais sensíveis, há o aumento do apetite e o sentido de olfato aumenta. Por isso tal cor é tão associada de forma recorrente a restaurantes, principalmente aos fast-foods (Figura 122).

O vermelho é uma cor quente, intensa e carregada de emoção. Quando associado ao universo feminino, remete a sedução, sensualidade e paixão (Figura 123).

Nos ambientes comerciais, o vermelho é muito utilizado para atrair a atenção, como, por exemplo, nas sinalizações de liquidações e promoções.

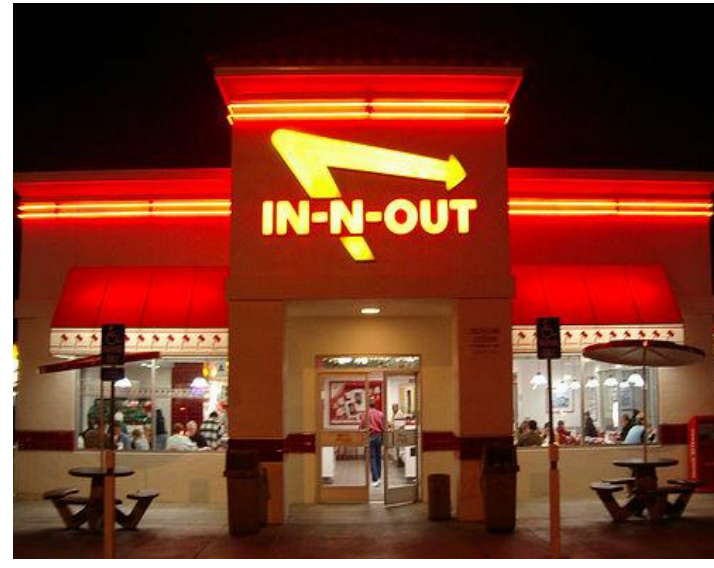

Figura 122. Loja In-n-out Fonte: $h$ ttp://partners.visitrenotahoe.com

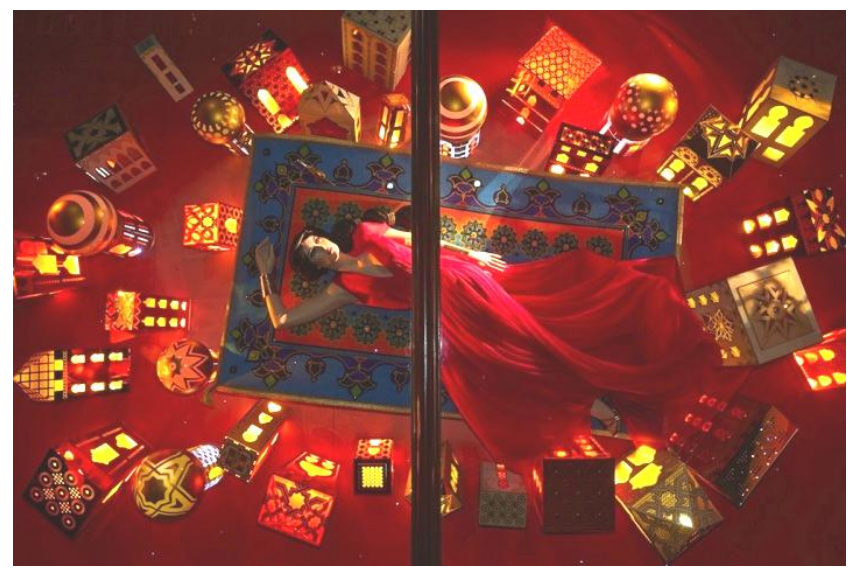

Figura 123. Vitrine de natal da loja Harrods em 2012 Fonte: http://www.vogue.co.uk/ 


\subsubsection{LARANJA}

A cor laranja induz o relaxamento, aumenta o potencial para o sono e diminui a frequência do fluxo sanguíneo (WALKER,1995). É uma cor quente que atrai com rapidez a atenção, indica formalidade e possui por si só um sentido de popularização (Figura 124 e Figura 125).

É muito indicado para espaços destinados à refeição e áreas sociais, pois tal como a cor vermelha, o laranja tende a elevar o apetite.

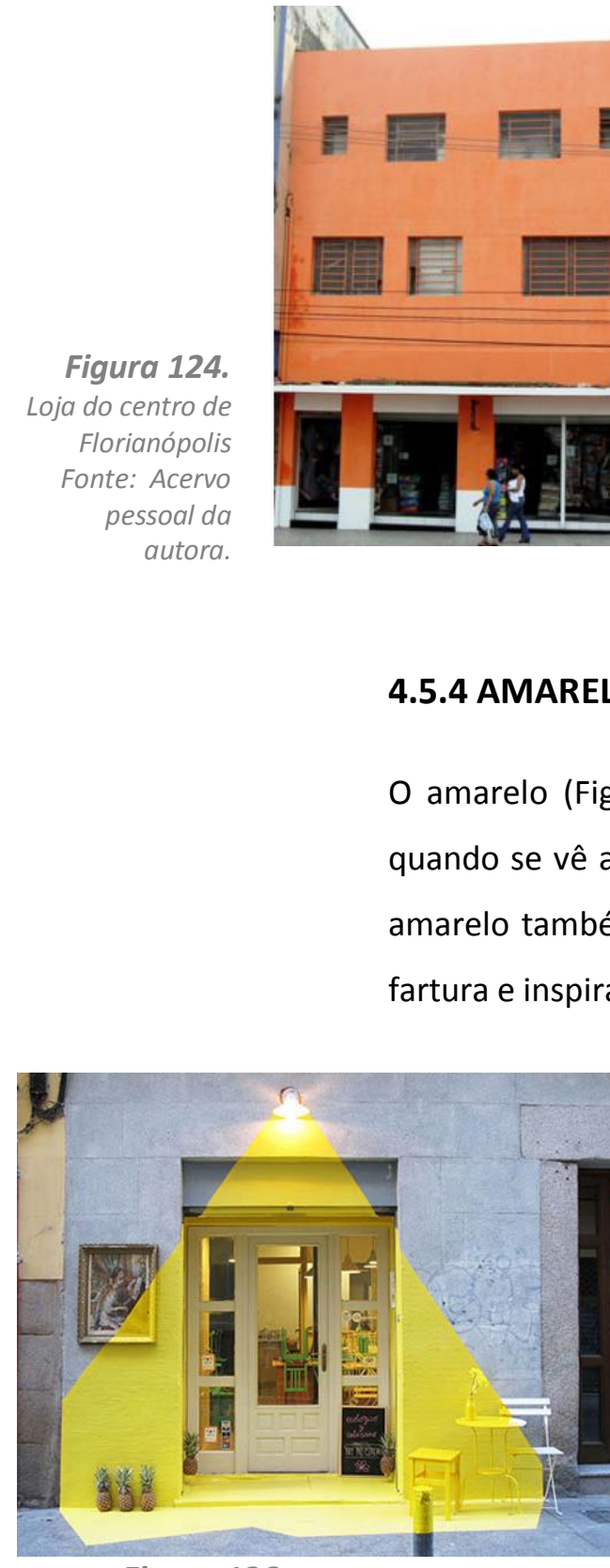

Figura 126. Espaço Rayen em Madrid Fonte:http://www.archilovers.com/projects/105
Figura 125. Vitrine da loja Cole Fox Hardware em São Francisco Fonte: https://blog.vendh q.com/post/649018 26935/

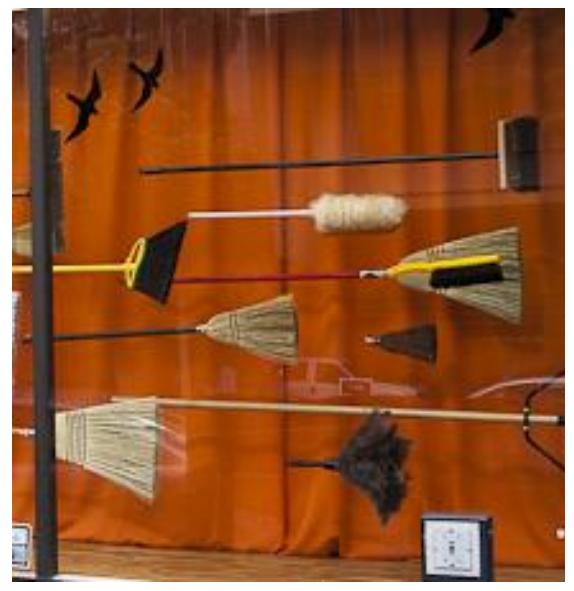


É uma cor com grande luminosidade, transbordando os limites, tornando os ambientes maiores do que na realidade são. Deve-se ter cautela ao utilizála, pois de acordo com Walker (1995) tende a sinalizar coisa barata, temporariedade e quando associada ao preto, transmite a mensagem de cuidado (Figura 128).

Figura 128. River Island Windows 2015 Fall, London Fonte:

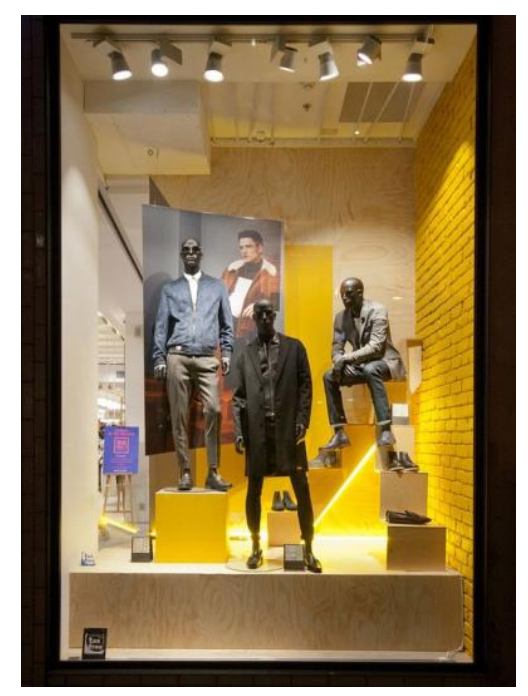

\subsubsection{VERDE}

Verde (Figura 129 e Figura 130) é uma cor fria, que transmite sensações de segurança, liberdade, coragem, saúde, esperança, limpeza e até energia. Segundo Lourenço e Sam (2011) o verde é utilizado nas vitrines para associar a marcas e produtos uma ideia de frescor.

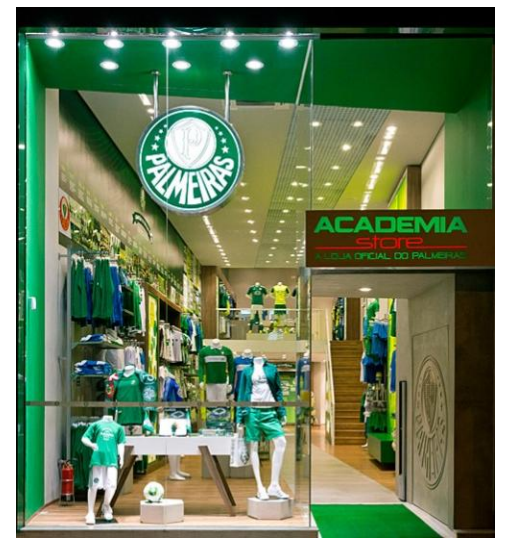

Figura 129. Loja Palmeiras em São Paulo Fonte: Acervo pessoal da autora.

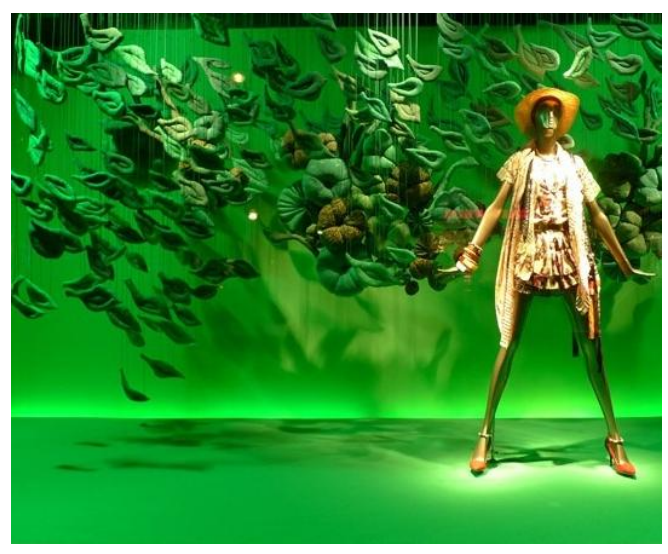

Figura 130. Vitrines da loja Printemps (2011) Fonte: https://br.pinterest.com/pin/561050066053660100/ 


\subsubsection{AZUL}

O azul é uma cor mais tranquilizadora (Figura 131 e Figura 132), segundo WALKER (1995) diminui a pulsação, aprofunda a respiração, reduz a transpiração, abaixa a temperatura do corpo e favorece a diminuição do apetite.

$\mathrm{Na}$ associação de produtos, o azul é usualmente explorado para chamar a atenção em artigos de limpeza, medicamentos e certos tipos de alimentos.

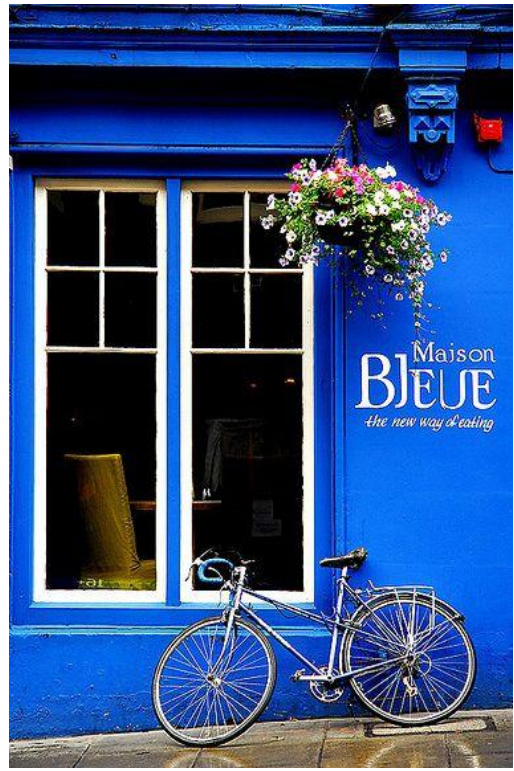

Figura 131. Fachada da loja Maison Bleue em Edimburgo - Escócia Fonte: https://br.pinterest.com/pin/49539664626862011/

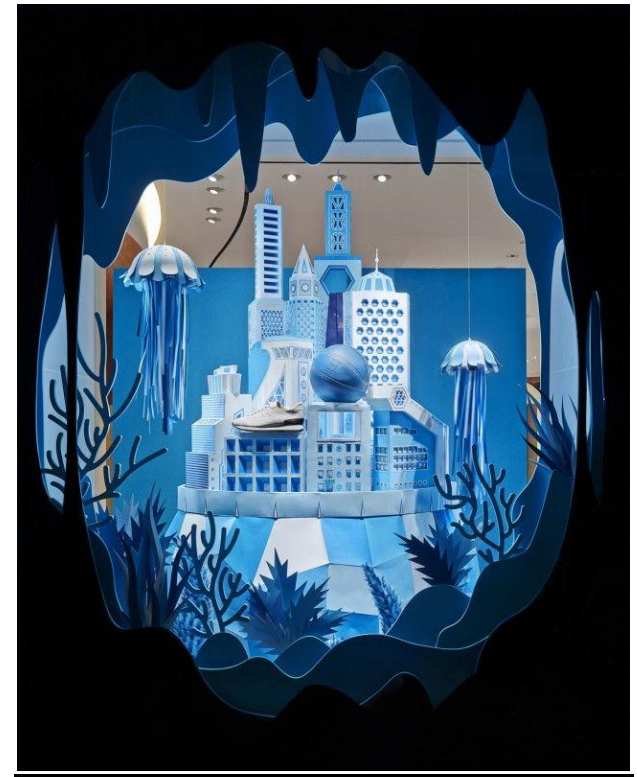

Figura 132. Vitrine da Loja Hermès de Beverly Hills Fonte: http://strictlypaper.com/blog/tag/layering/

\subsubsection{VIOLETA}

Violeta (Figura 133 e Figura 134) é a cor da intuição, magia, fantasia, sonho, mistério, etc. Mas também pode estar associado a sentimentos de paixão, amor e exclusividade. $\mathrm{Na}$ antiguidade, era um pigmento caro para ser produzido e por isso acabou-se por se tornar símbolo da realeza.

Em tons claros, aproxima-se das propriedades alegres da cor rosa. E junto da sua cor complementar, o amarelo, possui uma grande atratividade. 


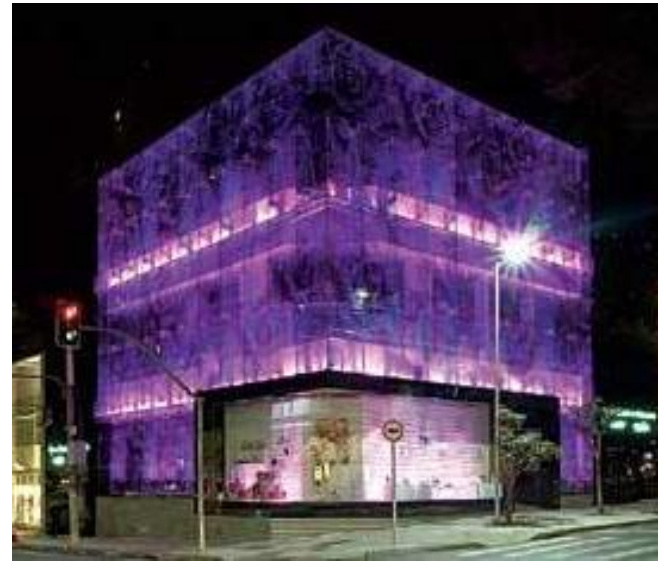

Figura 133. Loja Santa Elena (2010) da rua Oscar Freire - São Paulo Fonte: https://arcoweb.com.br/

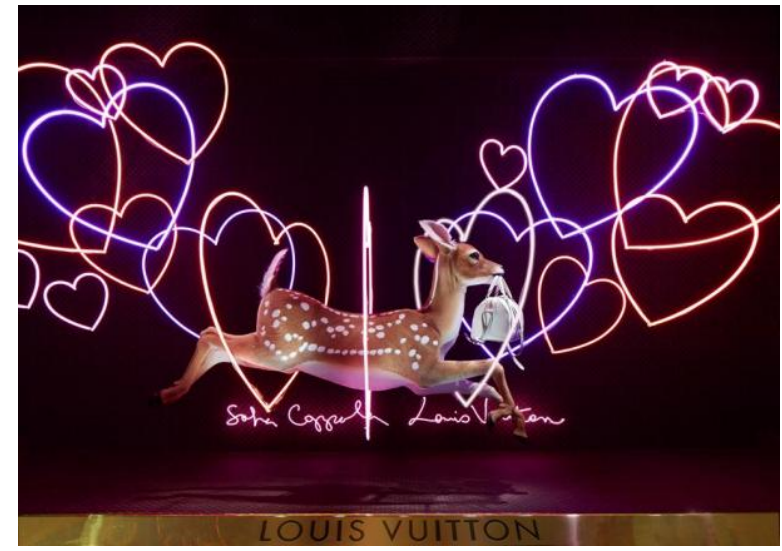

Figura 134. Vitrine da loja Louis Vuitton (2013) Fonte: $h$ ttp://reccalee.com/2013/10/louis-vuitton-the-new-scbag-windows/

\subsubsection{PRETO}

Fisicamente falando, o preto é a ausência de cor, pois este absorve todos os raios luminosos, não refletindo nenhum. O preto pode carregar uma carga de negatividade, tristeza, opressão. Seu excesso traz monotonia ao espaço e pode causar certo distanciamento e isolamento (Figura 135 e Figura 136).

Ao ser agrupado com outras cores, o preto traz a sensação que as demais são mais claras do que são, valorizando estas.

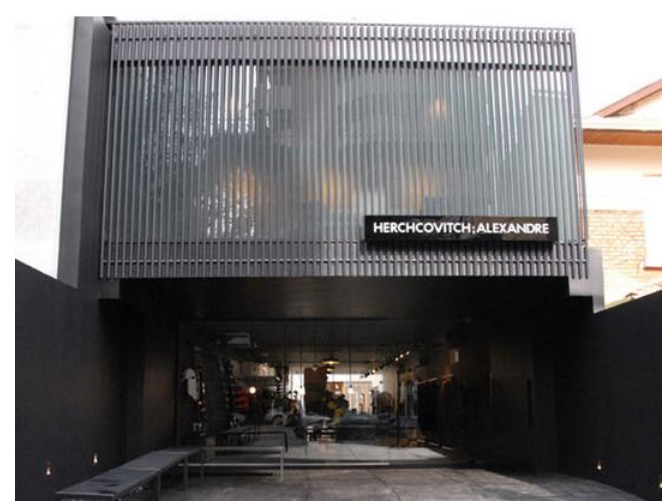

Figura 135. Loja do Herchcovitch em São Paulo, onde o preto é fortemente explorado. Fonte: Acervo pessoal da autora

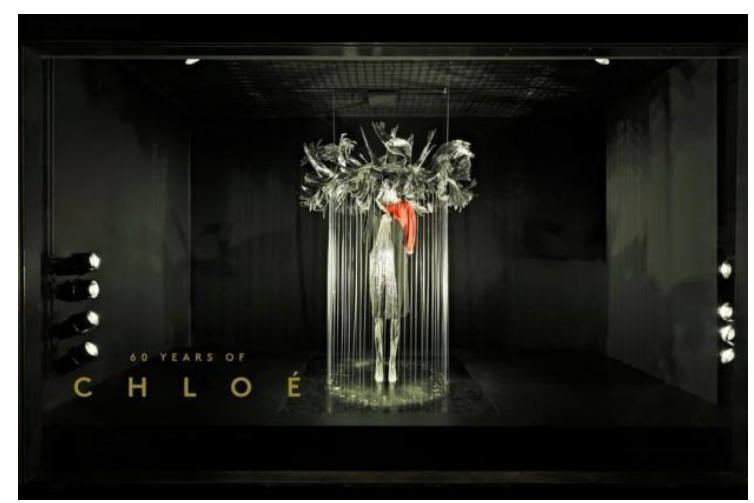

Figura 136. O excesso do preto na vitrine da loja Chloé. Fonte:http://mannequinmall.com/inspiration/100-creative-storedisplay-window-designs-part-1/

O preto também está associado ao sofisticado, nobreza e à seriedade. Não è a toa, que grandes marcas do segmento do luxo projetam seus espaço explorando o uso do preto (Figura 137). 
Figura 137.

O preto na composição das vitrines de marcas de
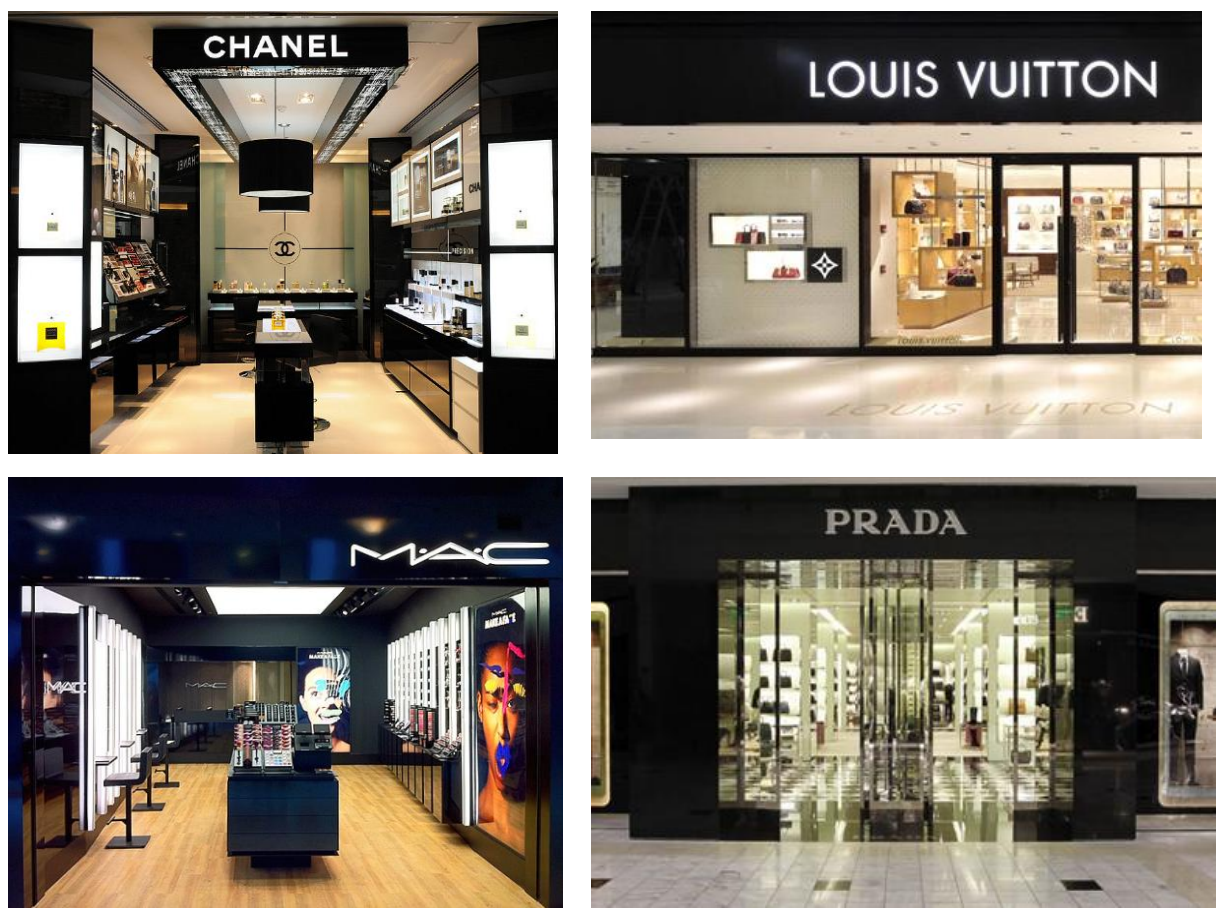

\subsection{ELEMENTOS DECORATIVOS E DE APOIO}

Os elementos decorativos e de apoio são todos aqueles presentes na vitrine, que podem ser utilizados para facilitar a composição e a exposição dos produtos, tornando os objetos mais visíveis e atraentes.

Os materiais e elementos que serão utilizados na vitrine devem, além de auxiliar na exposição dos produtos, atender aos critérios de composição, buscando configurar a atmosfera da vitrine de modo a transmitir os conceitos planejados para este espaço e marca. De acordo com Sackrider et at. (2009):

A escolha do suporte destinado a expor os produtos é crucial para a coerência da estruturação da vitrina e sua mensagem global, mas é também difícil, haja vista a amplitude do leque de possibilidades. (SACKRIDER et al., 2009, p. 194)

Qualquer que seja a decoração da vitrina, sua mensagem e seu estilo, os elementos de apoio estão invariavelmente presentes. Os mais comuns são suportes, cubos, nichos, prateleiras e manequins. Estes elementos são 
peças versáteis, tanto no quesito de poderem ser repetidas em diferentes composições de vitrine, quanto em serem usadas como complemento na decoração da vitrine e apoio para a valorização dos produtos.

Os suportes tem a função de elevar os produtos, de modo a aproximá-los do ponto focal do observador. Com os suportes, o produto é retirado do chão e posto numa categoria de destaque.

Com os suportes é possível criar diferentes níveis de altura, volume e formas. As composições que tiram partido dos suportes podem ter formas variadas, tamanhos e aplicações diferentes, assumindo inclusive o papel de peças decorativas.

É importante que o tamanho do produto seja proporcional ao tamanho do suporte, pois produtos muito maiores que o suporte pode transmitir uma sensação de instabilidade e insegurança. Enquanto nas situações contrárias, onde o suporte é muito maior, o produto pode não receber o destaque necessário.

Estes elementos de apoio podem ser industrializados (Figura 138), já projetados com o propósito de dar suporte às mercadorias, em diversos tipos de materiais, como ferro, plástico, madeira, ou podem ser uma adaptação de outros materiais (Figura 139). Neste último caso, os suportes podem ser de materiais ainda mais variados e normalmente assumem um papel decorativo importante (Figura 140).

Figura 138. Suporte de metal da vitrine da Dior em Paris (2014)

Fonte: https://br.pinterest.com/pin/ 113504853084389491/i

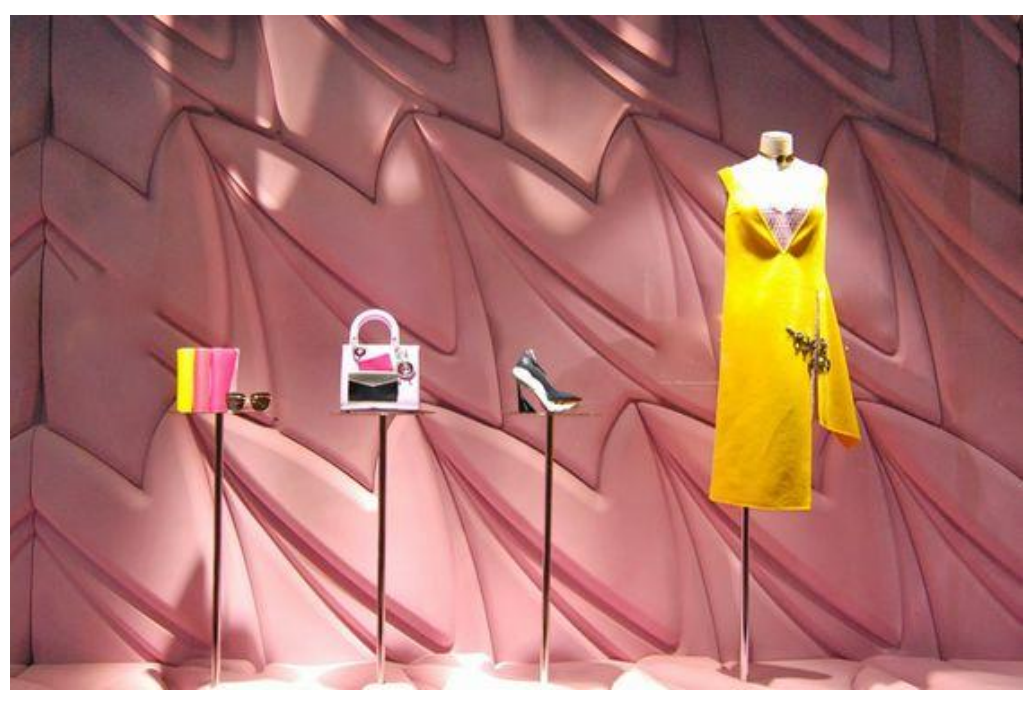


Figura 139.

Suporte formando por diversos sacos empilhados na vitrine da loja Max Mara em

Milão (2015)

Fonte:

https://br.pinterest.com/pin/ 289989663486081712/

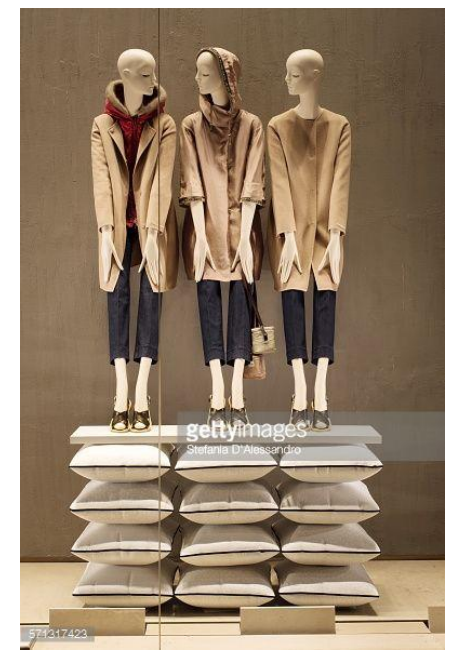

Figura 140.

Grandes mãos funcionam como suporte da loja Fenwick em Londres (2015)

Fonte:

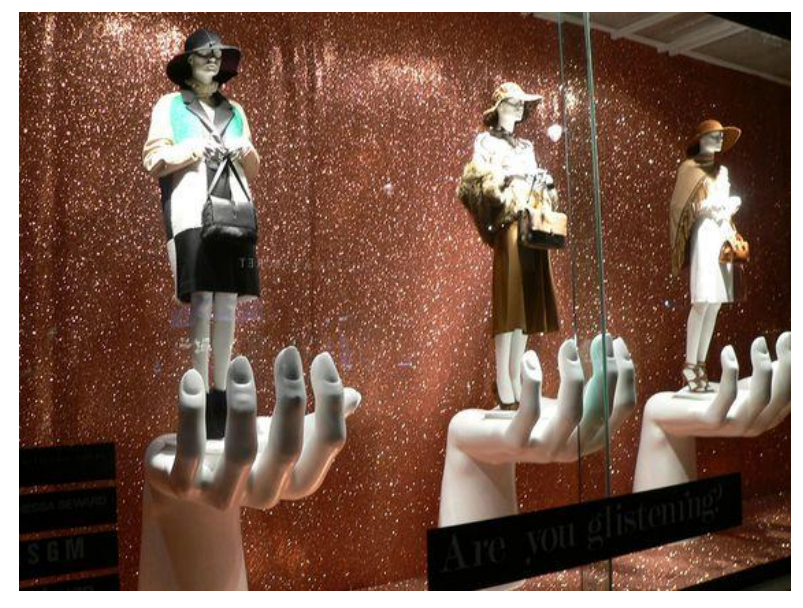

O cubo é outro tipo de aparato utilizado para apoiar expositores ou o próprio produto, que pode ser usado em todos os setores comerciais e em todos os tipos de vitrines.

A altura dos cubos pode variar conforme o projeto visual. Algumas vitrines exploram o uso de cubos com diferentes alturas, com o intuito de criar um ritmo para a composição (Figura 141). Há ainda situações onde o ritmo ocorre exatamente pela repetição de cubos iguais (Figura 142). 
Figura 141. Loja Forever 21 , Londres

(2015)

Fonte:

http://retaildesignblog.net/2

015/10/22/forever-32windows-2015-fall-londonuk/

Figura 142. Loja TOPSHOP, Nova Zelândia Fonte: https://br.pinterest.com/pin/ 289989663486807973/
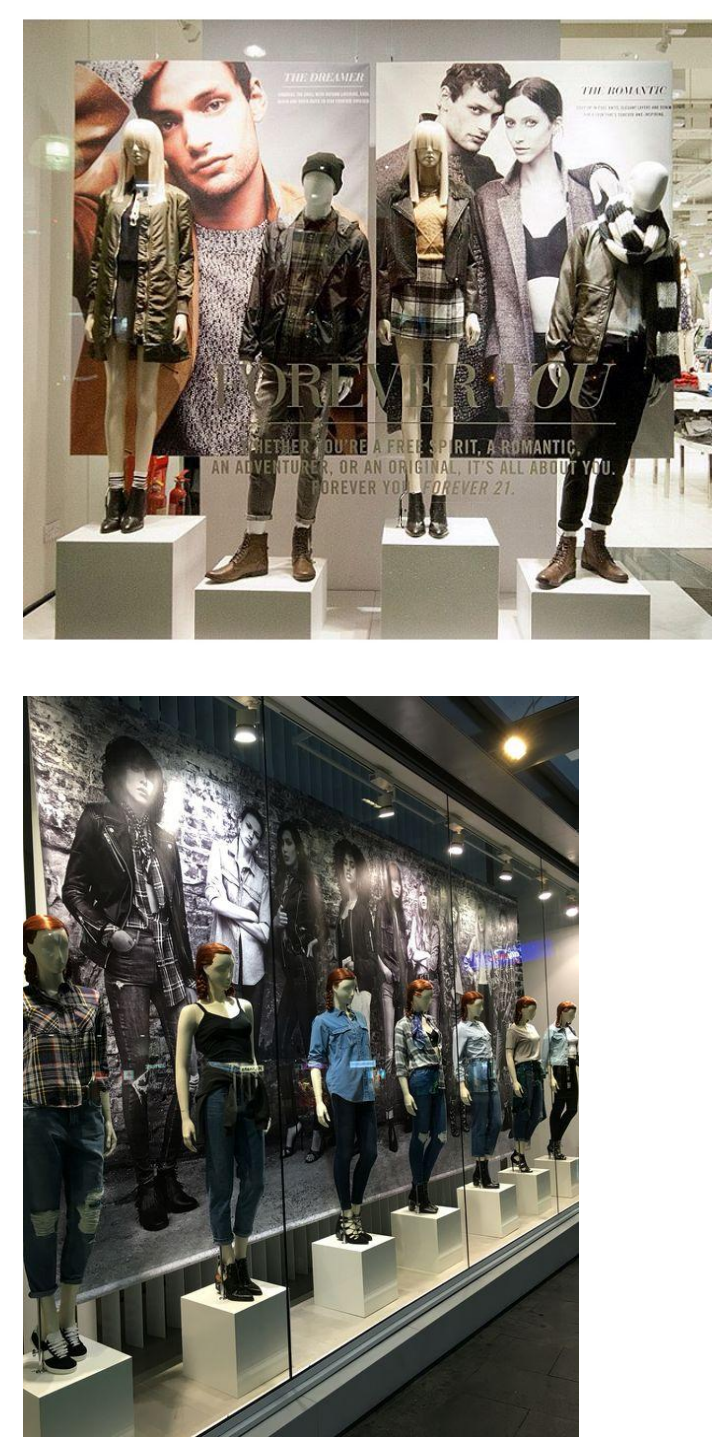

Pode ser produzido com diversos tipos de materiais, como metal (Figura 143), madeira (Figura 144), papelão e plástico. Quanto mais resistente for o material, mais vantajoso será para os casos em que forem reaproveitados em novas composições da vitrine. 
Figura 143.

Cubos de metal da loja GLASSONS da Nova Zelândia Fonte: https://br.pinterest.com/pin/ 289989663485571437/

Figura 144. Cubos de madeira da loja Printemps Homme em Paris

Fonte:

https://br.pinterest.com/pin/ 289989663486798098/
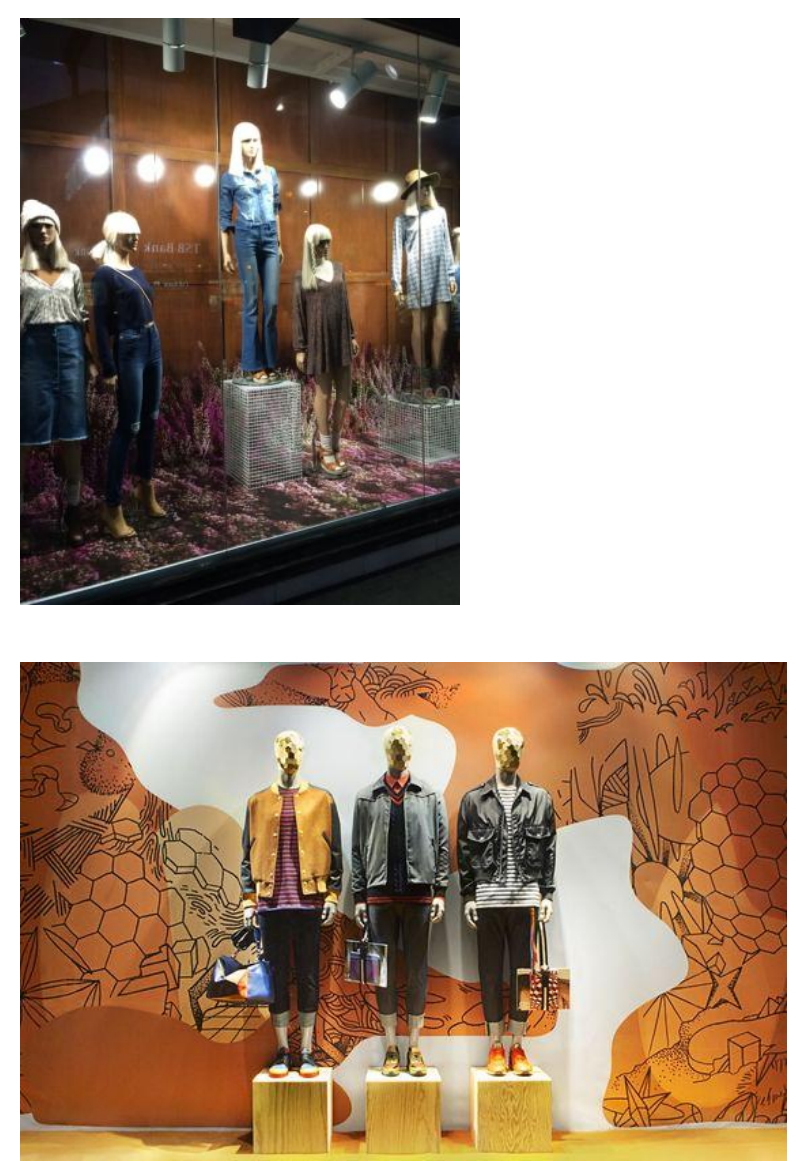

Em geral, os cubos usados possuem cores neutras, de modo a não interferir na composição visual, mas podem ser utilizados como elementos decorativos (Figura 145 e Figura 146), ajudando a compor a atmosfera da vitrine.

Figura 145. Cubos coloridos da loja Topshoes em Londres Fonte:

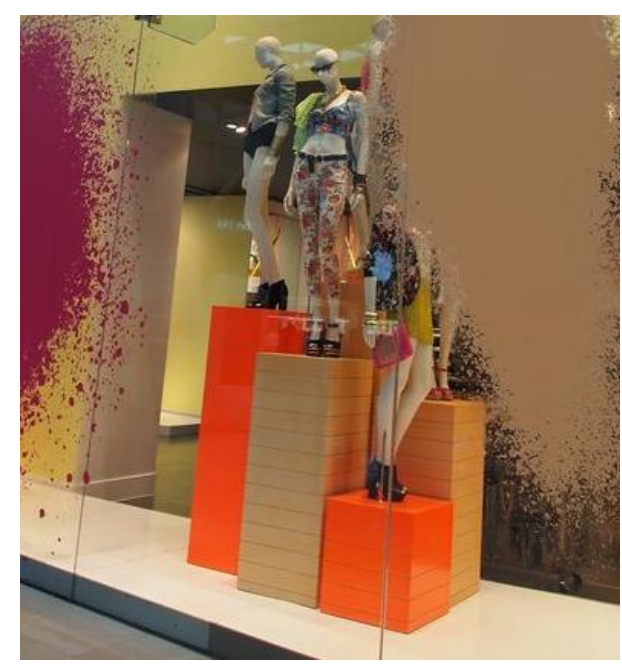


Figura 146. Cubos coloridos no formato de caixas de presente em

Nova lorque

Fonte: https://br.pinterest.com/pin/ 322148179573740968/

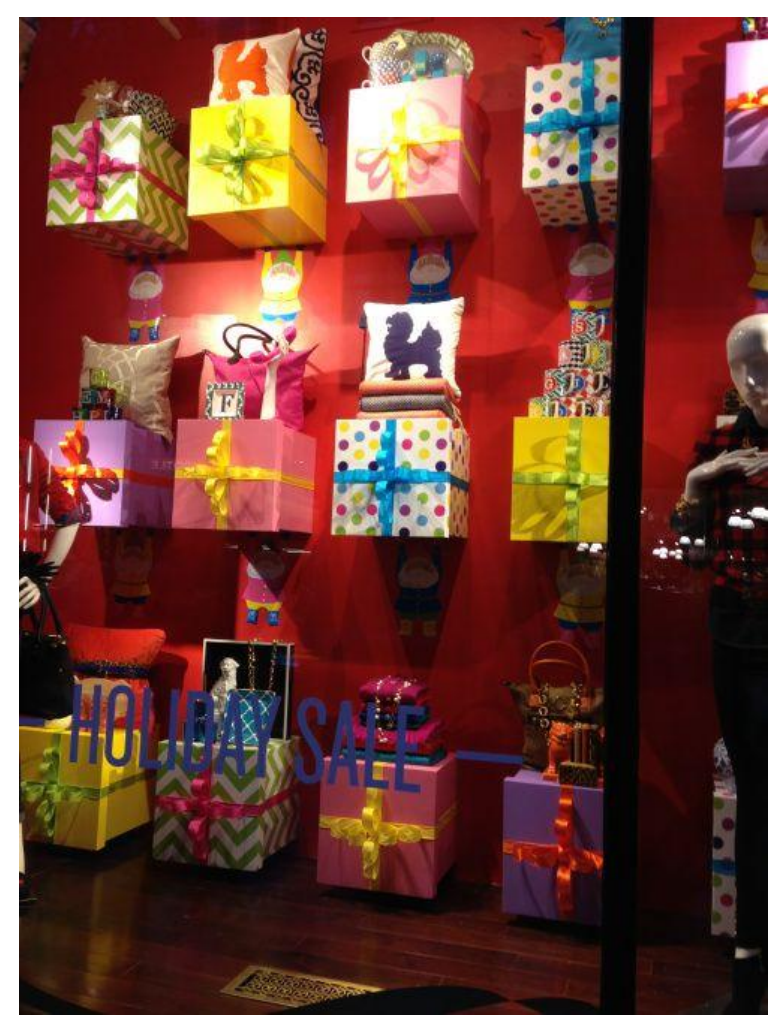

Outro elemento de suporte muito utilizado nas vitrines são os nichos. Os nichos emolduram o produto, trazendo destaque e valorizando a peça. Em geral, estes podem assumir dois papéis na composição. Podem funcionar praticamente como vitrines em miniatura (Figura 147 e Figura 148) ou serem usados como decoração em praticamente todo tipo de arranjo (Figura 149).

Tal como os cubos, os nichos podem ser fabricados de vários materiais, com as cores mais diversas possíveis.

Figura 147. Vitrine da loja Maria Filó em São Paulo (2011) Fonte: http://www.mariafilo.com.br

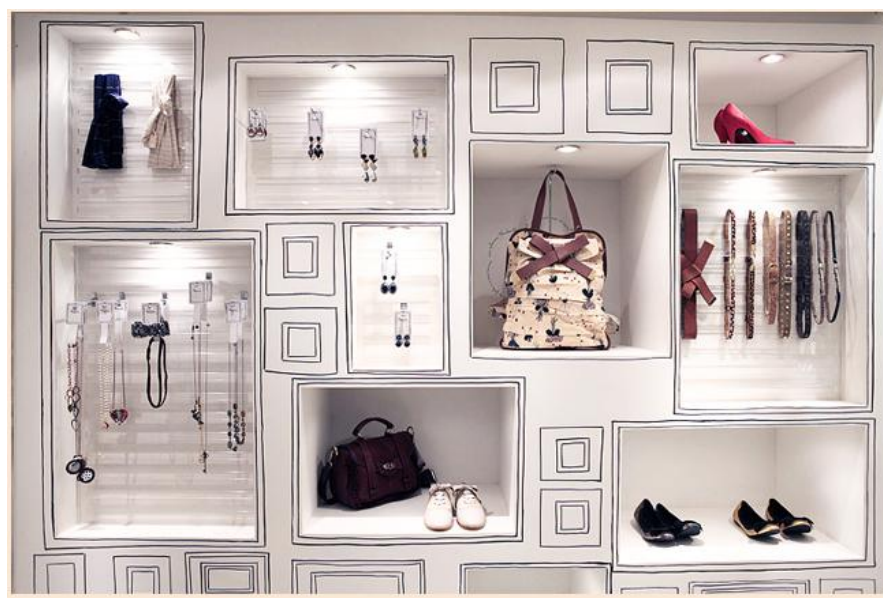


Figura 148. Nichos na vitrine Clarks em Londres (2014)

Fonte:

HTTP://retaildesignblog.net/2 014/06/01/clarks-windows2014-spring-london

Figura 149. A composição de nichos forma uma árvore de natal na vitrine da loja Anthropologie

(2010)

Fonte:
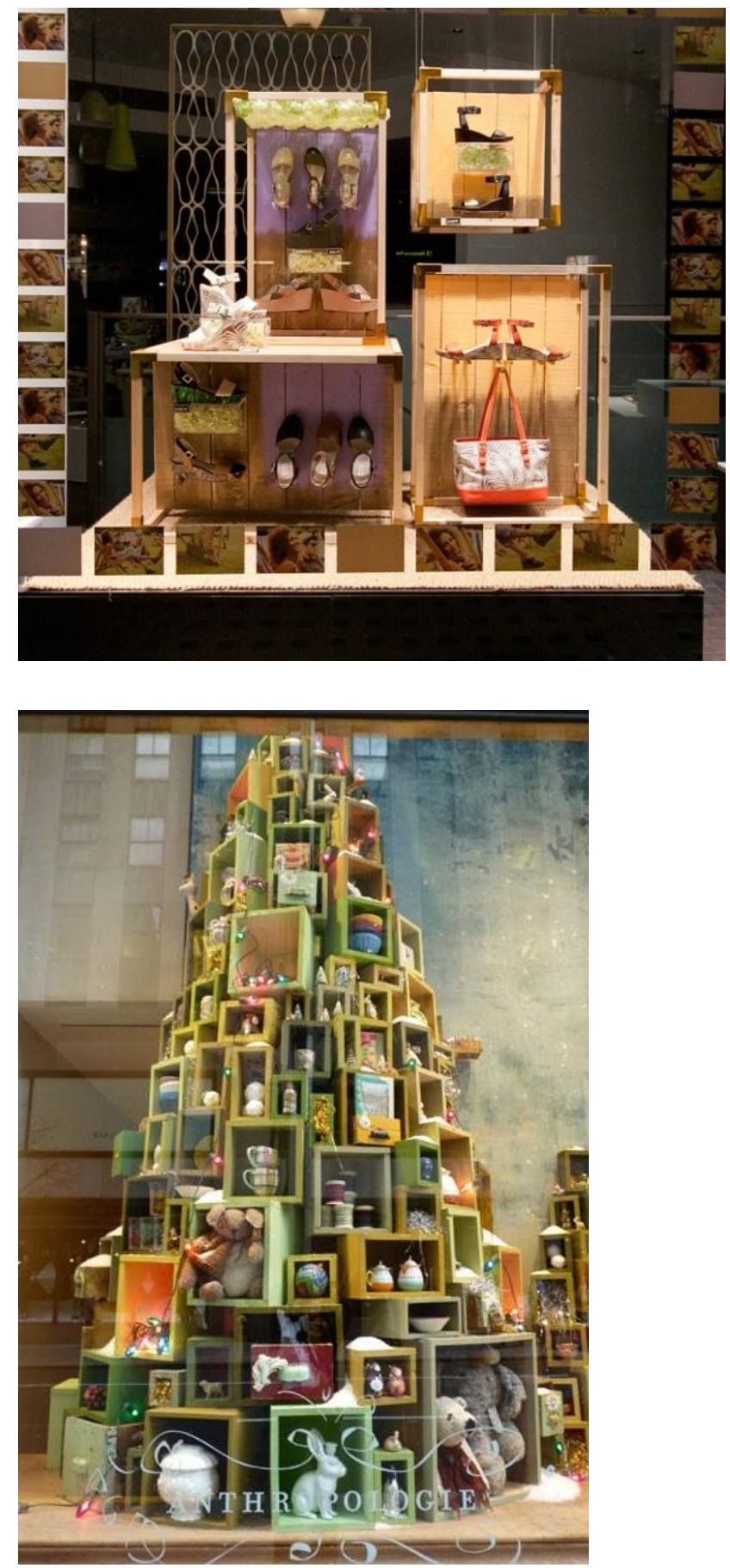

É possível além dos nichos, utilizar prateleiras para expor produtos pequenos, que necessitem de destaque. É uma boa solução também nas situações onde se busca expor uma maior quantidade de produtos em um pequeno espaço. 
Figura 150.

Prateleiras ajudam a

expor os produtos na vitrine da loja Fendi em

Tókio

Fonte:

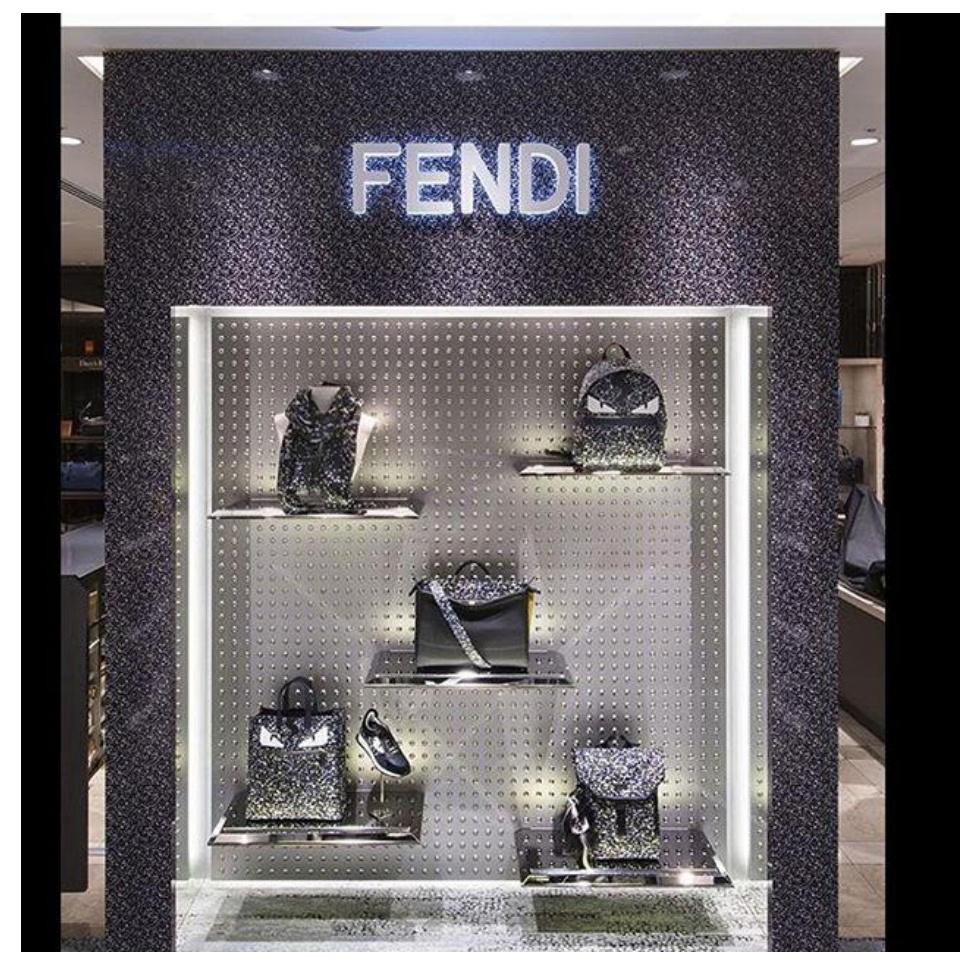

São soluções mais econômicas e quando utilizadas numa quantidade significativa, tendem a ser padronizadas, evitando criar uma poluição visual.

Podem ser móveis, fixas ou pendentes (Figura 151), com formatos retangulares padronizados ou até diferenciados (Figura 152 e Figura 153), assumindo um papel decorativo na composição.

Figura 151.

Vitrine com prateleiras pendentes da loja Megan Park na Austrália Fonte:

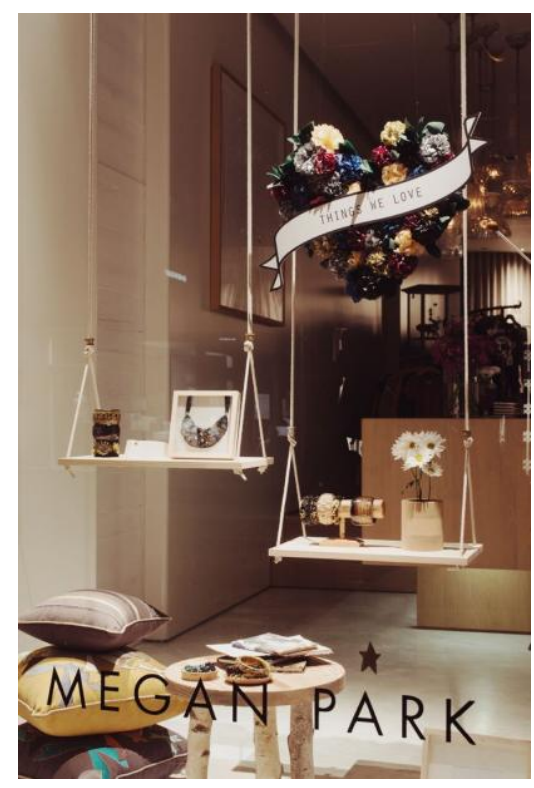


Figura 152.

Prateiras de apoio das bolsas parecem derreter, assumindo papel decorativo na vitrine da loja Louis Vuitton em

Zurique

Fonte:

https://br.pinterest.com/pos hnoir/

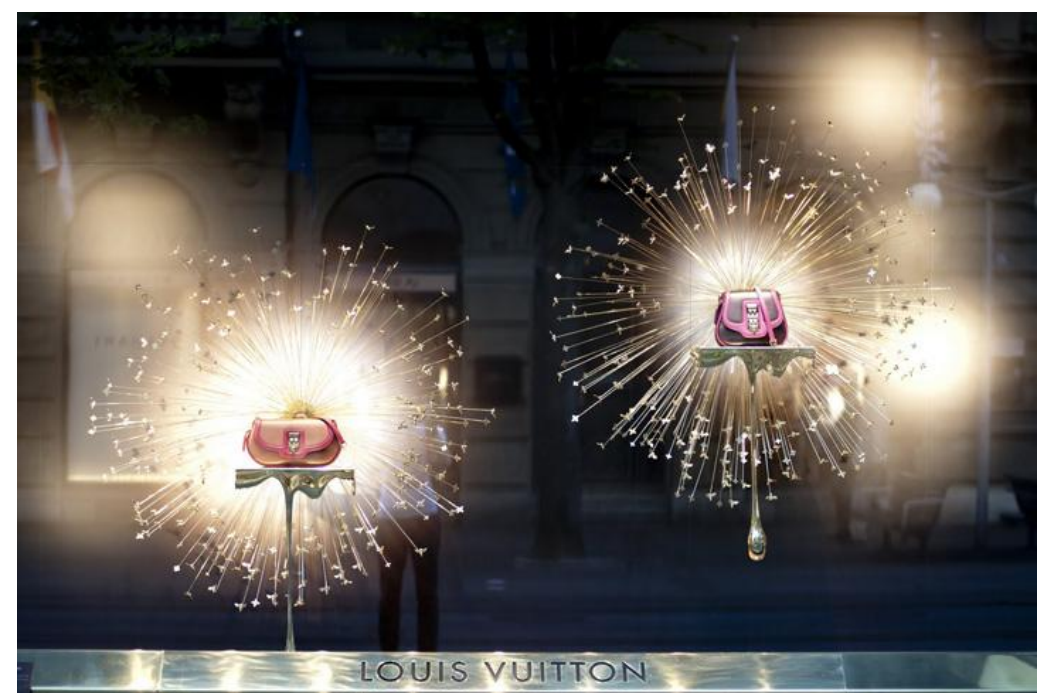

Figura 153.

Prateleiras em formato de

nuvem

da loja Cosas de Lu em

Almenara (Espanha)

Fonte:

https://br.pinterest.com/pin/

67765169369283021/

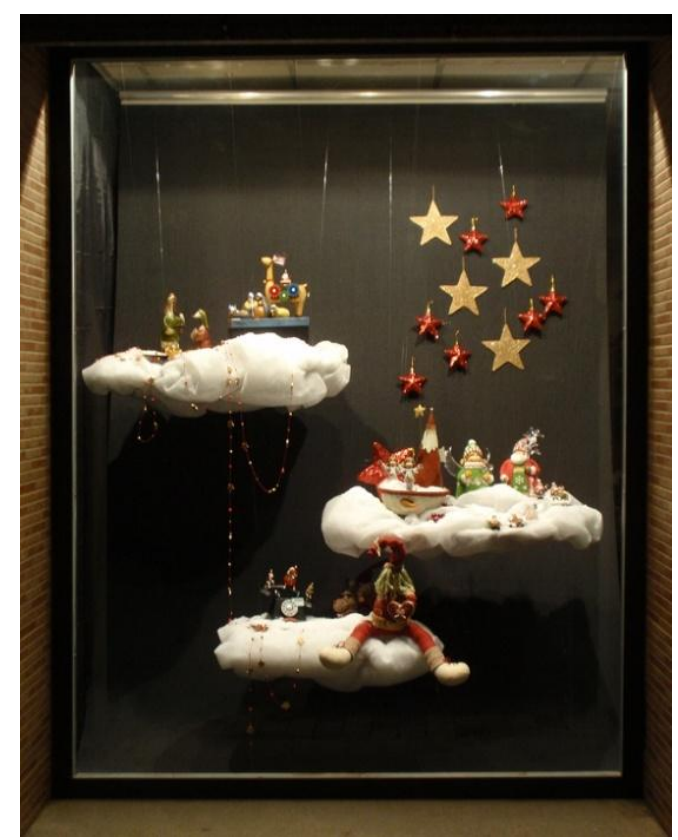

Por fim, outro elemento utilizado na exposição são os manequins. Talvez este seja o tipo de expositor mais importante e por isso, é um dos elementos mais usados. É um "vendedor silencioso", pois além de vestir as mercadorias que estão à venda, ele nos informa como devemos usálas, seu caimento e quais as melhores combinações. (SACKRIDER et al., 2009)

Os modelos de manequins encontrados na exposição de vitrines são extremamente variáveis (Quadro 4). Desde bustos, corpetes, cabeças, braços, mãos e pernas são utilizados como suporte. 


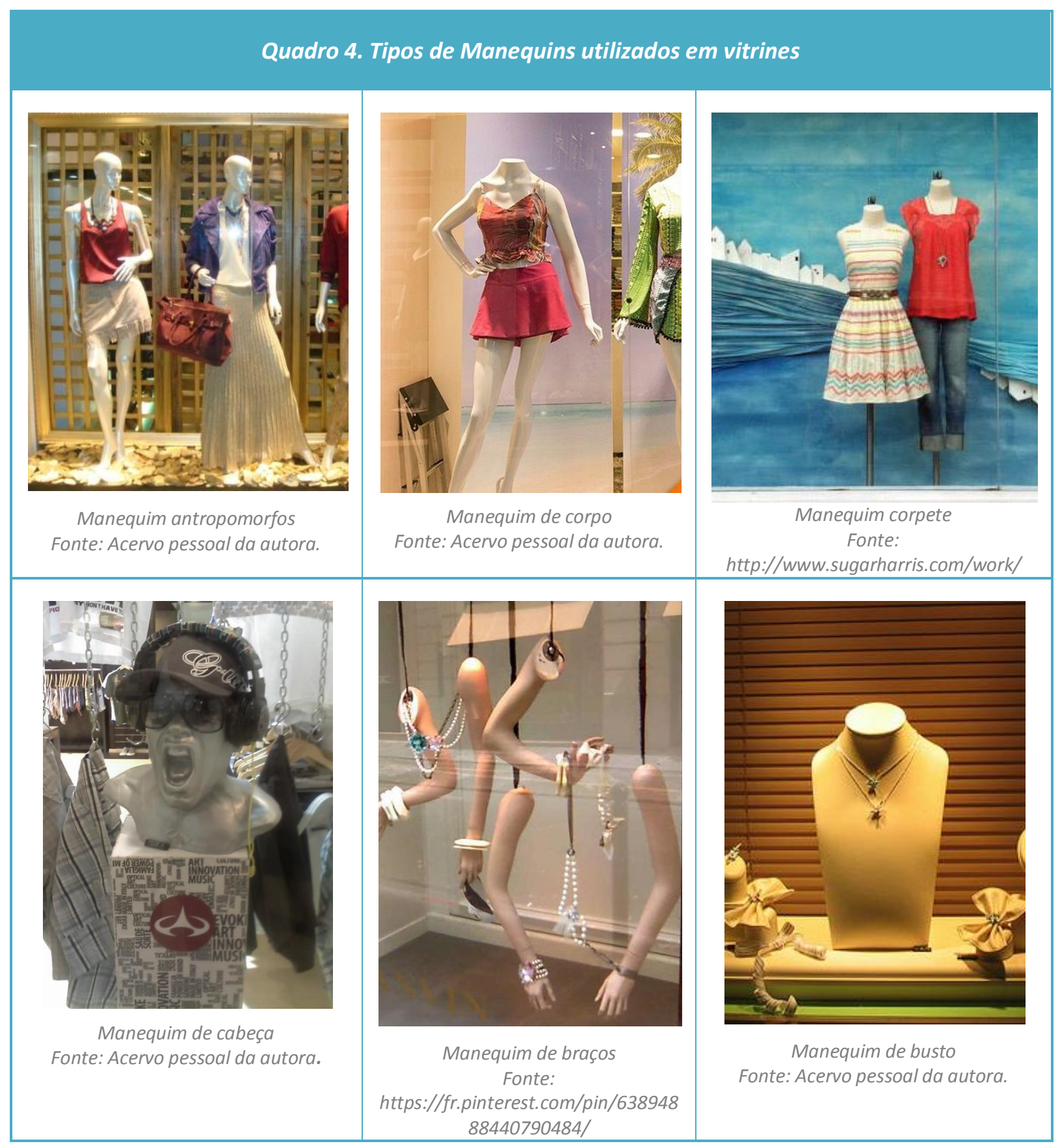

Existem ainda manequins articuláveis que podem simular movimentos e conferem ainda mais vida as vitrines (Quadro 5). Este tipo de manequim é uma peça chave para montar cenas dentro das vitrines, pois ajudam a criar o conceito e atraem a atenção do observador. 


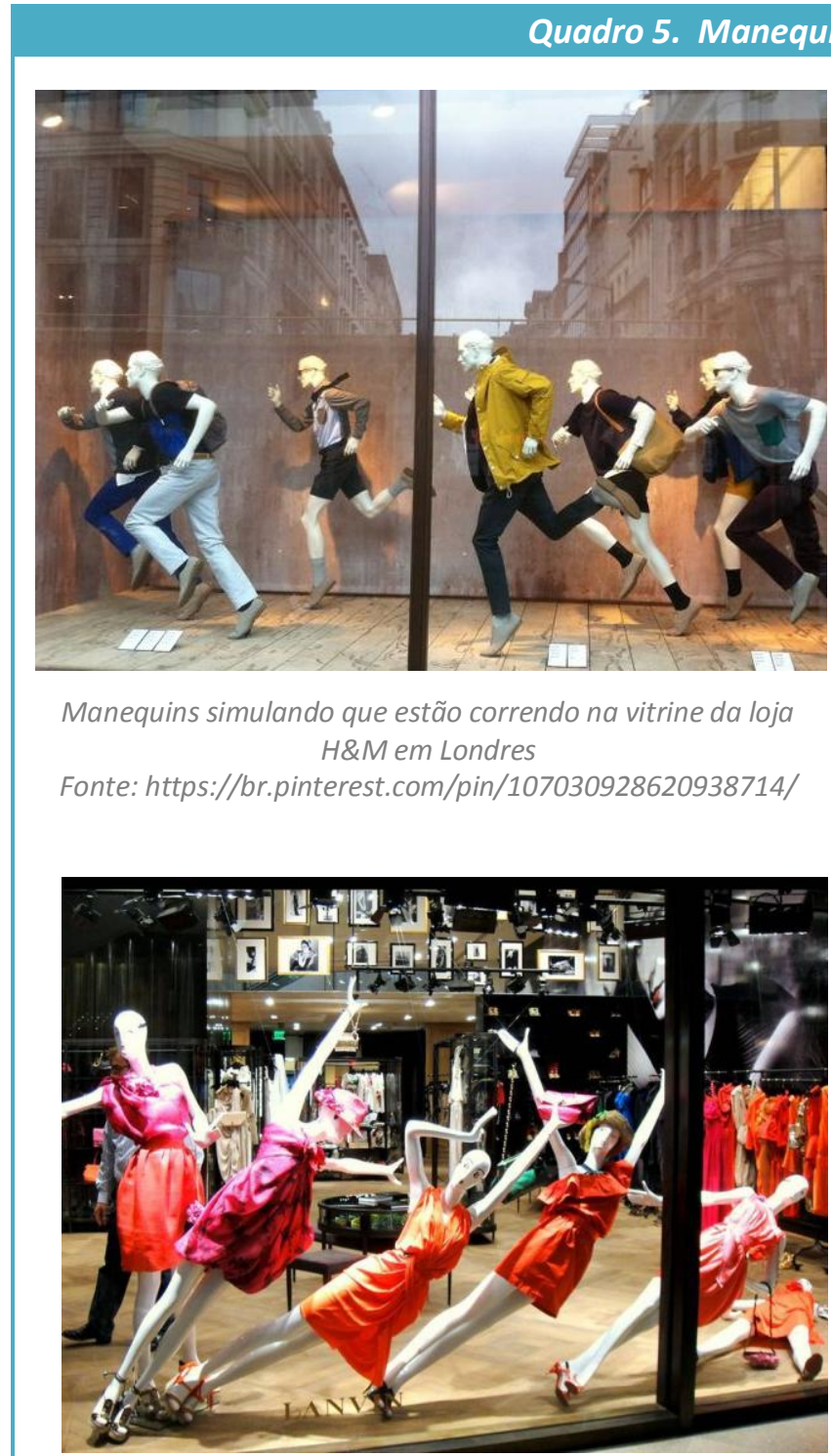

Manequins simulando um desmaio na vitrine da loja Lanvin em Las Vegas

Fonte: Acervo pessoal da autora.

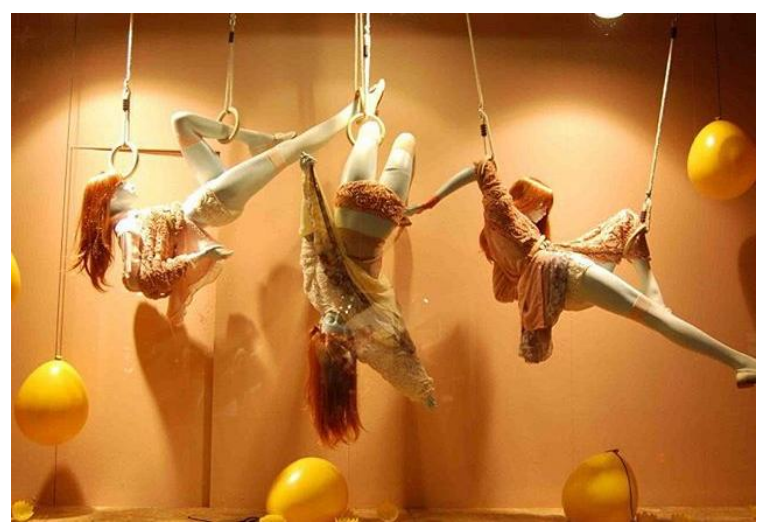

Manequins acrobatas na vitrine da loja Selfridges em Londres Fonte: https://br.pinterest.com/pin/70931762853716403/

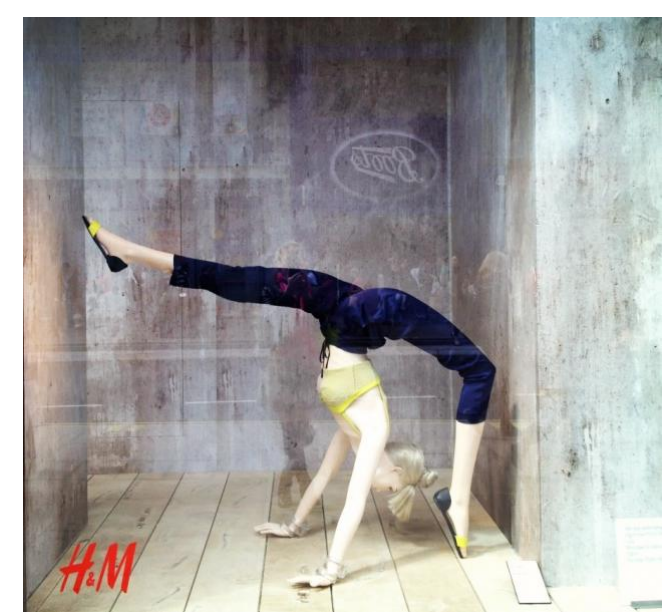

Manequim ginasta da vitrine da loja H\&M em Londres Fonte:

https://meetvilma.wordpress.com/2012/07/15/hmgymnastic-star/

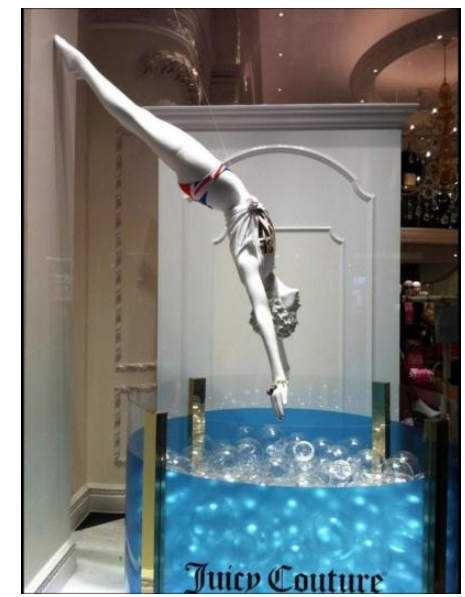

Manequim mergulhando em uma piscina de bolinhas na vitrine da loja Juicy Couture Fonte:

https://br.pinterest.com/pin/138556126012282262/

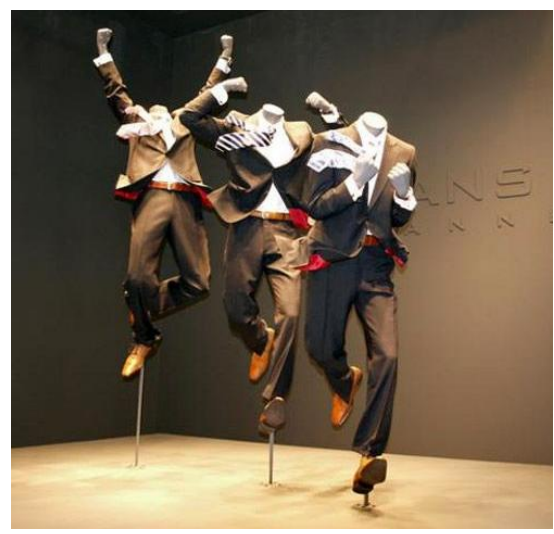

Manequins saltando

Fonte: http://www.vendaotimizada.com/ideias-paravitrines-e-montras-de-lojas/ 
O manequim está diretamente ligado ao público que a loja deseja atingir. Quanto mais o consumidor se sentir simbolizado pelo manequim, maior é a chance do desejo pela compra ser despertado. 0 estilo do manequim deve também estar de acordo com os conceitos da loja e dos produtos por ela vendidos. Assim como a vitrine e o ambiente interno das lojas, os manequins devem transmitir os valores da marca.

Cada vez mais tem surgido opções no mercado de outras categorias de manequins, além dos femininos e masculinos adultos. Manequins infanto-juvenis (Figura 154), infantis e de bebês (Figura 155) já são encontrados nas vitrines das lojas destes segmentos.

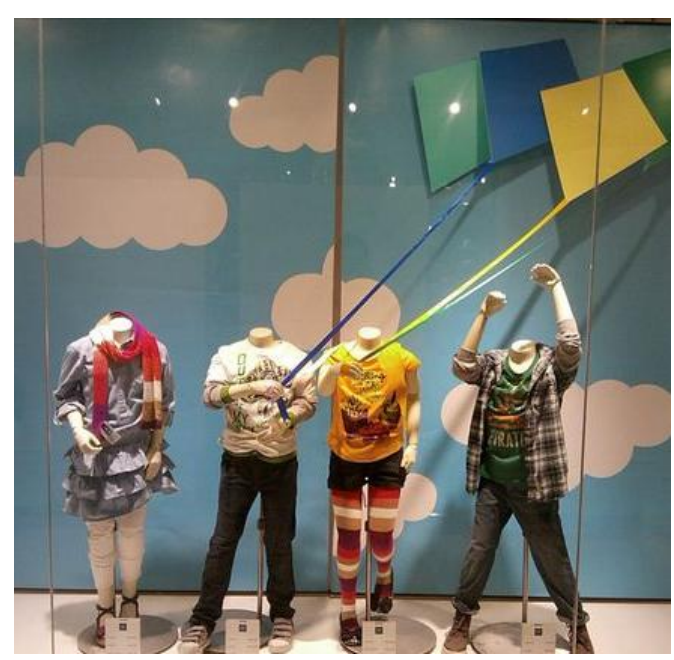

Figura 154. Manequins Infanto-juvenis da loja da Gap

Fonte: http://displayhunter.blogspot.com.br/2012/

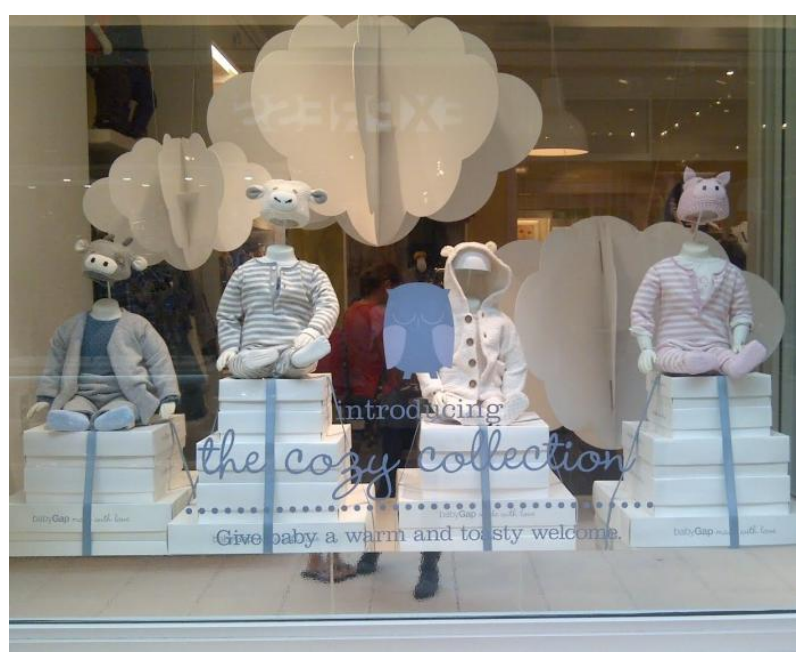

Figura 155. Manequins bebê da loja Gap Fonte:

http://asmallbit.blogspot.com.br/2012/09/windowdisplays.html

Porém a imposição da indústria da moda por um padrão perfeito de corpo ainda é visto replicado nos manequins. A grande maioria dos manequins encontrados ainda possuem corpos muito magros e esbeltos. As exceções são as recentes lojas destinas ao público plus-size, que se preocupam em utilizar manequins que retratem seu consumidor (Figura 156). Além deste caso, raríssimas são as lojas que optam por manequins mais próximos dos corpos reais, como os vistos na Figura 157. 


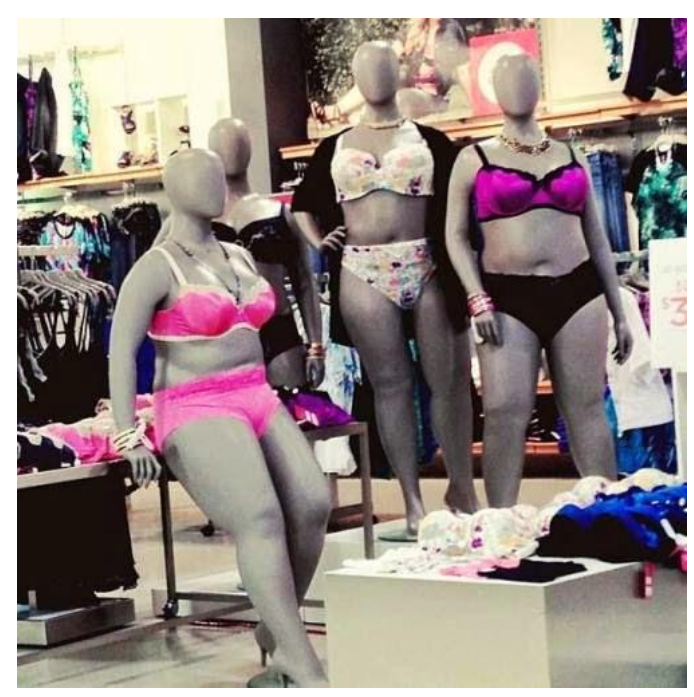

Figura 156.

Manequins plus-size Fonte: http://blogmulherao.com.br/16187

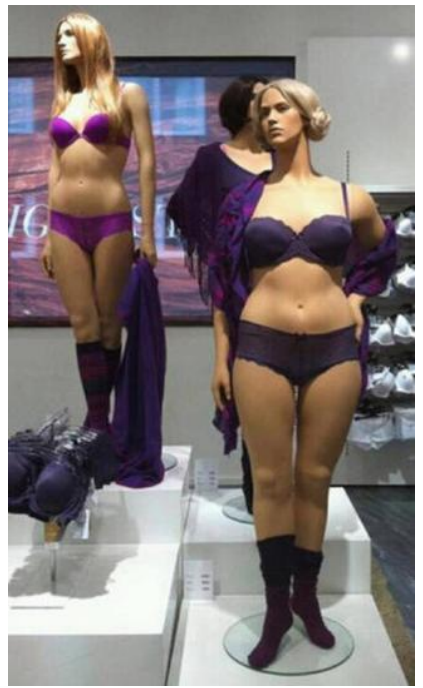

Figura 157.

Manequins com corpos mais realísticos Fonte: http://twirlit.com/2013/03/13/

Se difícil é encontrar manequins com corpos mais "cheinhos", mais raros ainda são os exemplos de lojas que já utilizaram manequins que retratassem pessoas com deficiência física. Este é o caso de uma série de lojas em Zurique na Suiça. WE Fashion, Modissa PKZ, Schild e Bernies fizeram parte uma campanha para chamar atenção e conscientizar seu público para a aceitação de pessoas com deficiências físicas (Figura 158 e Figura 159).

Figura 158. Manequim com escoliose na vitrine da loja Modissa em Zurique Fonte: http://osocio.org/message/st orefronts-want-you-to-comecloser-but-this-time-its-alittle-different/

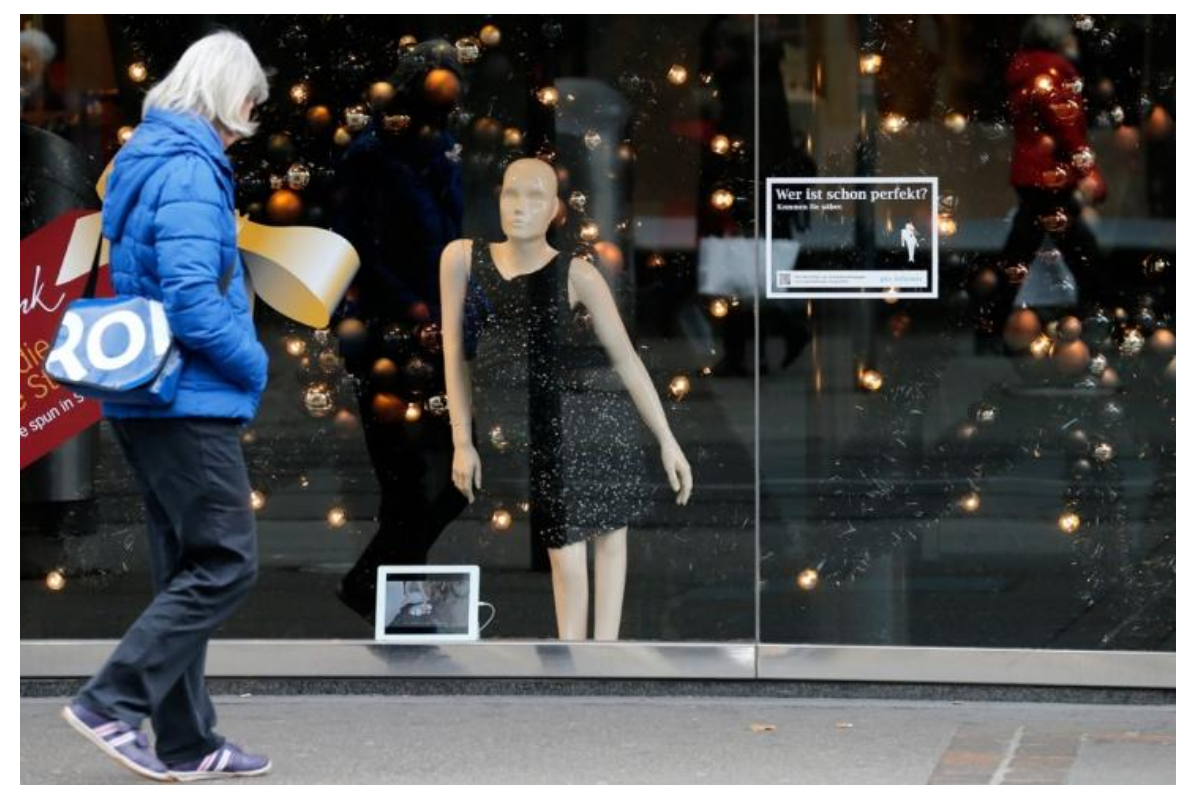


Figura 159.

Manequim cadeirante

Fonte:

http://www.demilked.com/be

cause-who-is-perfect-getcloser-disabled-mannequinnspro-infirmis/

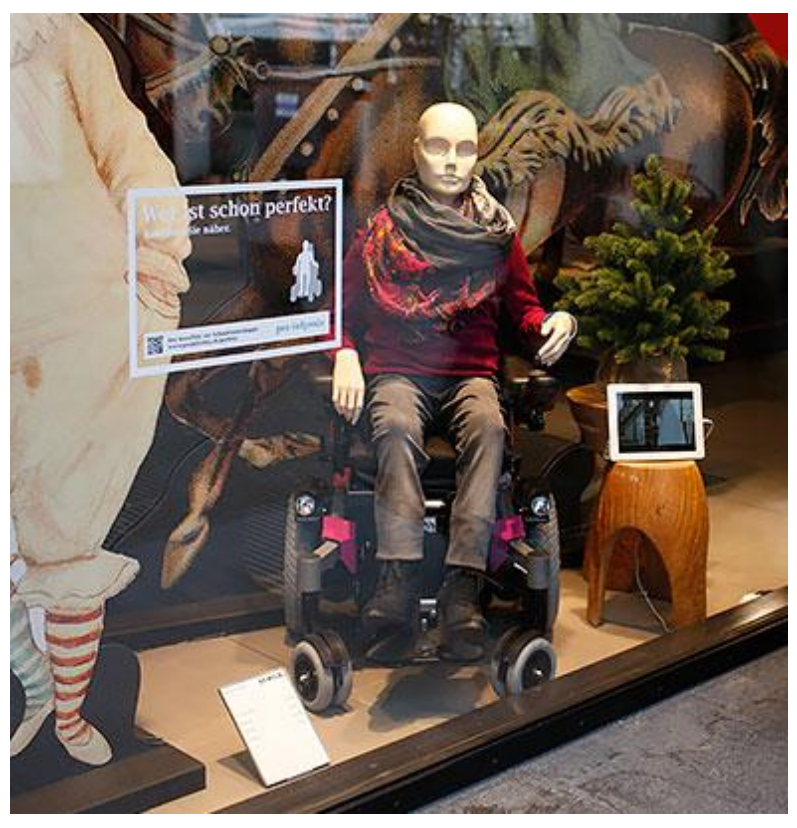

O engajamento veio da organização Pro Infirmis, que criou uma série de manequins especiais, feitos a partir de corpos de pessoas reais com algum tipo de deficiência física (Figura 160, Figura 161 e Figura 162). A campanha, intitulada "Quem é perfeito? Chegue mais perto", buscar trazer à tona a importância de não formar padrões de beleza, repensar os meios de consumo voltados a esse grupo de pessoas e aceitar a diferença, seja ela qual for.

Entre as pessoas retratadas, estavam uma pessoa em cadeira de rodas, uma que sofre de escoliose, uma pessoa amputada e uma com encurtamento dos membros.

Figura 160.

Manequim baseado na pessoa de cadeira de rodas Fonte: http://www.vilamulher.com.b $\mathrm{r} / \mathrm{bem}$ estar/comportamento/mane quins-para-deficientes-fisicos-

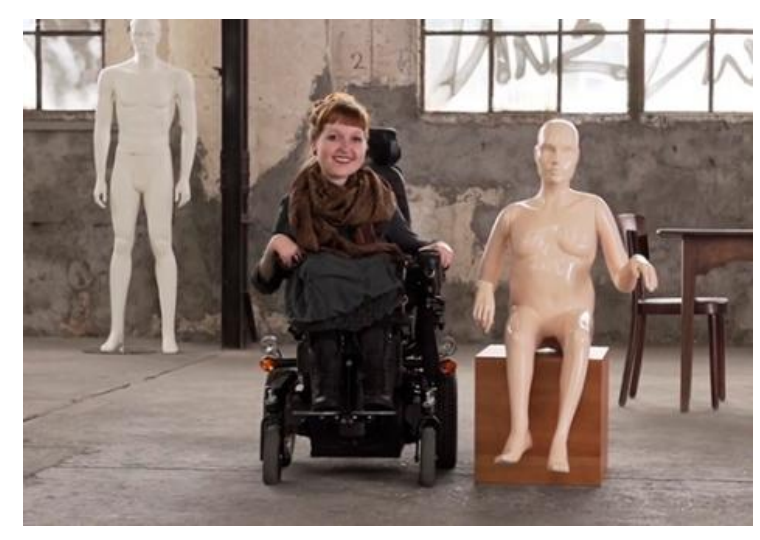


Figura 161. Manequim baseado na mulher com escoliose.

Fonte: http://www.vilamulher.com.b $r /$ bemestar/comportamento/mane quins-para-deficientes-fisicos11-1-69-994.html

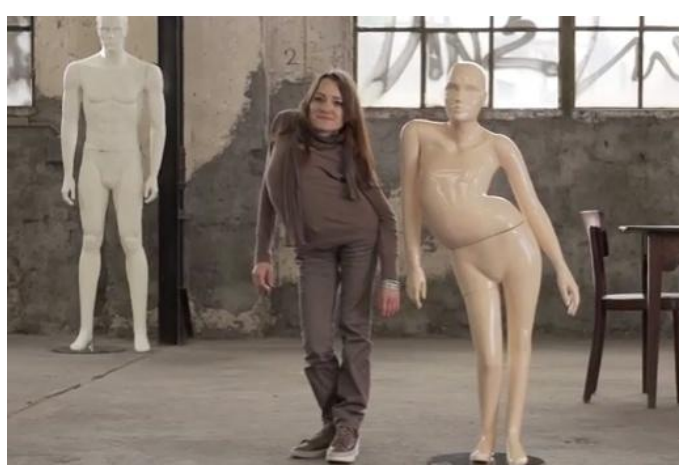

Figura 162. Manequim baseado no homem amputado Fonte: http://www.vilamulher.com.b $r /$ bemestar/comportamento/mane quins-para-deficientes-fisicos11-1-69-994.html

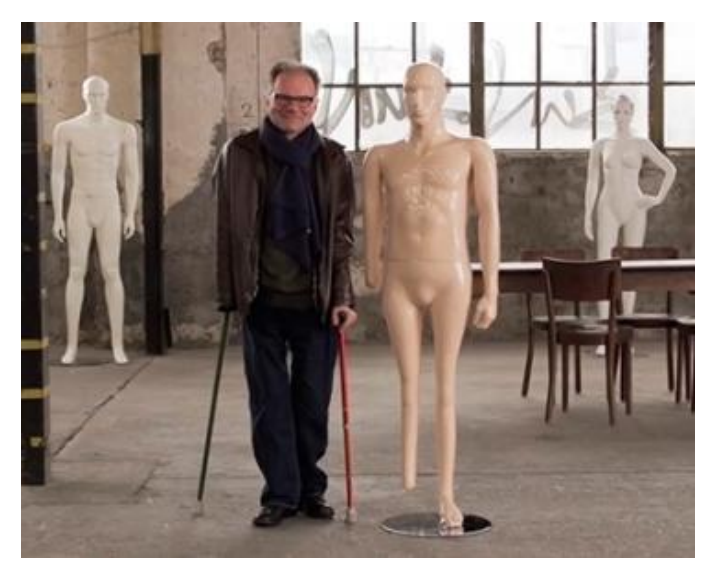

Há ainda outra categoria de manequins que não são antropomorfos, ou seja, não reproduzem com fidelidade as proporções humanas (Figura 163 e Figura 164). São manequins feitos sob encomenda e normalmente são utilizados essencialmente por marcas de luxo, pois se tornam mais viáveis pelo custo mais alto que possuem.

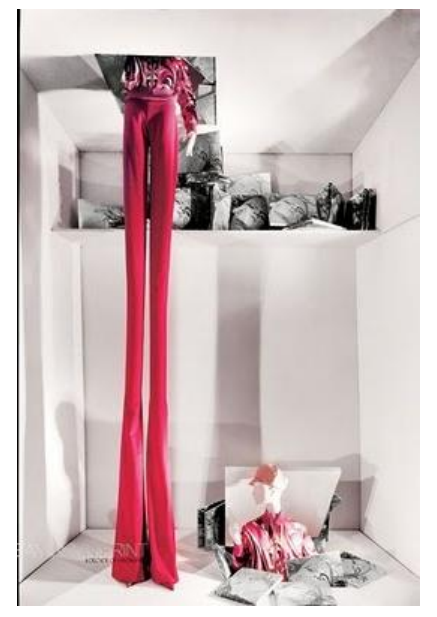

Figura 163. Manequins com pernas extremamente longas da loja Bergdorf Goodman Fonte: https://br.pinterest.com/chiustudio/window-display/

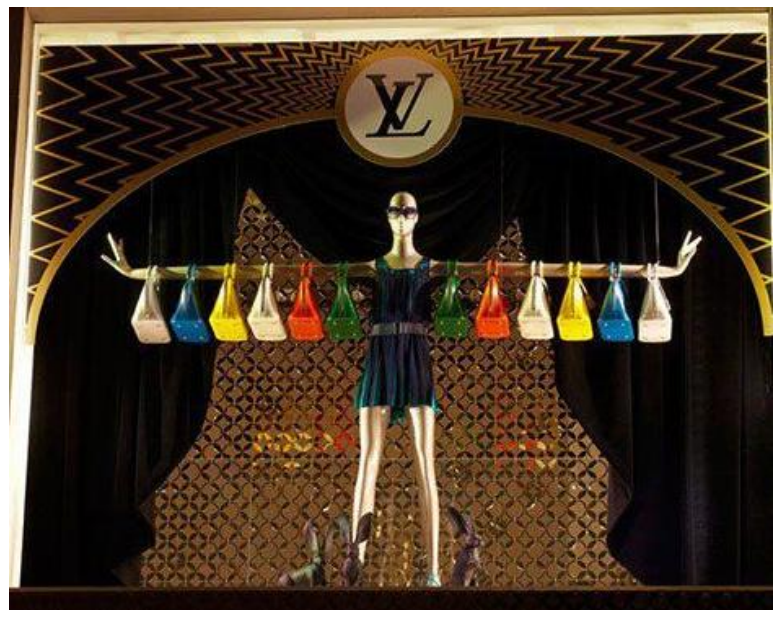

Figura 164. Manequins com braços extremamente longos da loja Louis Vuitton Fonte: http://www.dnaitalia.com/2015/02/8-consigliper-allestire-una-vetrina-di-successo/ 
E por fim, existem vitrines que utilizam manequins que mesclam figuras humanas com outros personagens, animais e até mesmo objetos (Quadro 6).

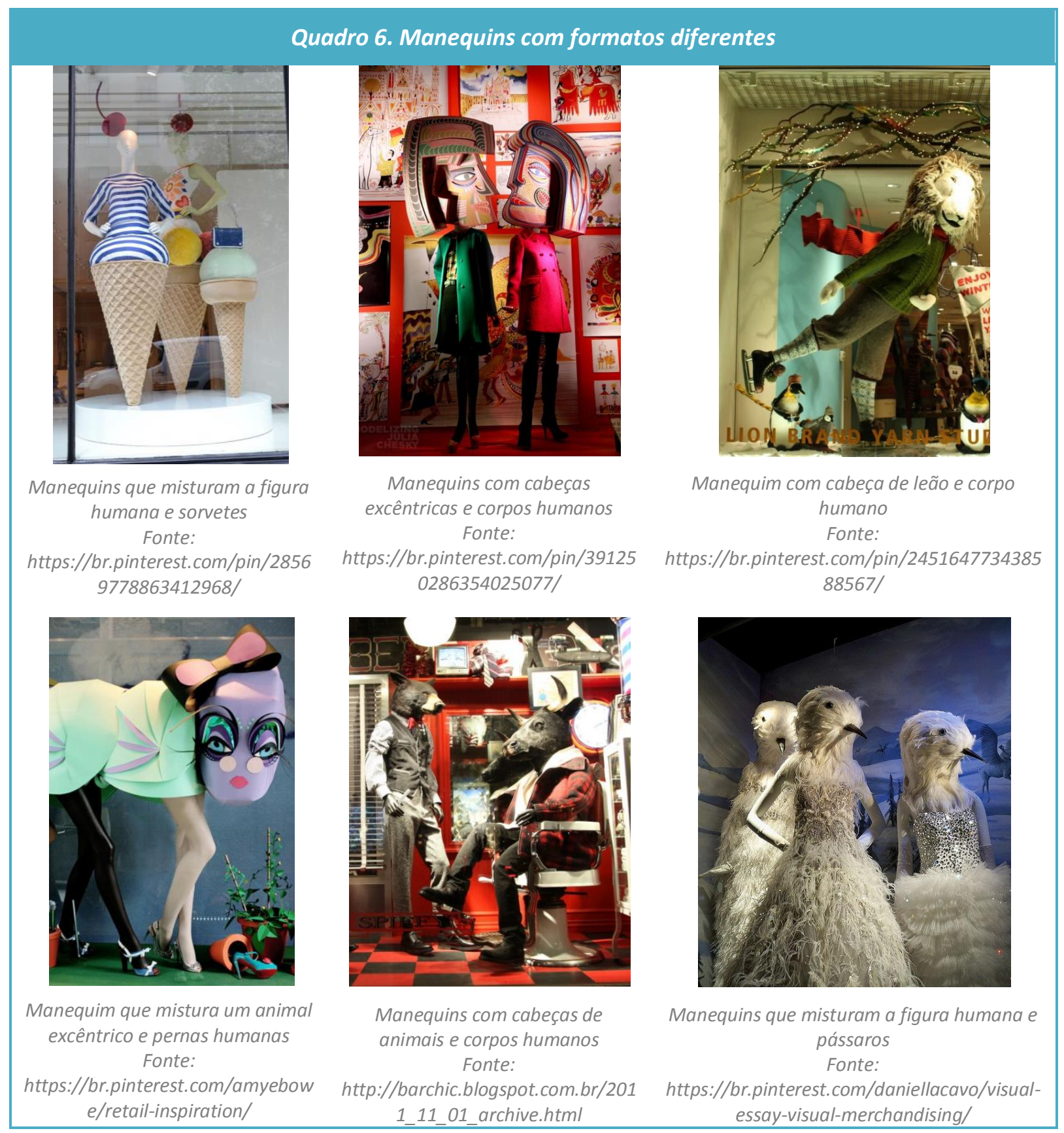

Além dos elementos de apoio descritos anteriormente - suportes, cubos, nichos, prateleiras e manequins, que podem ou não exercer função de decoração, existem elementos exclusivamente decorativos.

Os elementos exclusivamente decorativos é qualquer elemento que participa da composição da vitrine para destacar e valorizar a mercadoria, 
ajudando a criar a atmosfera do espaço. Como visto, a vitrine comunica por meio da imagem visual, usando parâmetros do design visual, como composição de cores, formas, iluminação e decoração. Pode servir para atrair a atenção do cliente, ornamentar a vitrine e como suporte de mercadoria.

Seja um mobiliário, como cadeiras, armários, mesas e espelhos, ou simplesmente decorações, o importante é que estes elementos tragam a funcionalidade ao ambiente, mas principalmente se integrem ao conceito da marca e vitrine desejado.

É o caso, por exemplo, da vitrine de verão de 2014 da loja Debenhams (Figura 165). O pássaro, que é um elemento decorativo, possui uma grande representatividade na composição. Juntamente com a cor verde, explorada nas laterais, piso e fundo, transmitem ao observador uma sensação de tropical, natural e refrescante.

Figura 165. Vitrine da loja Debenhams Fonte:

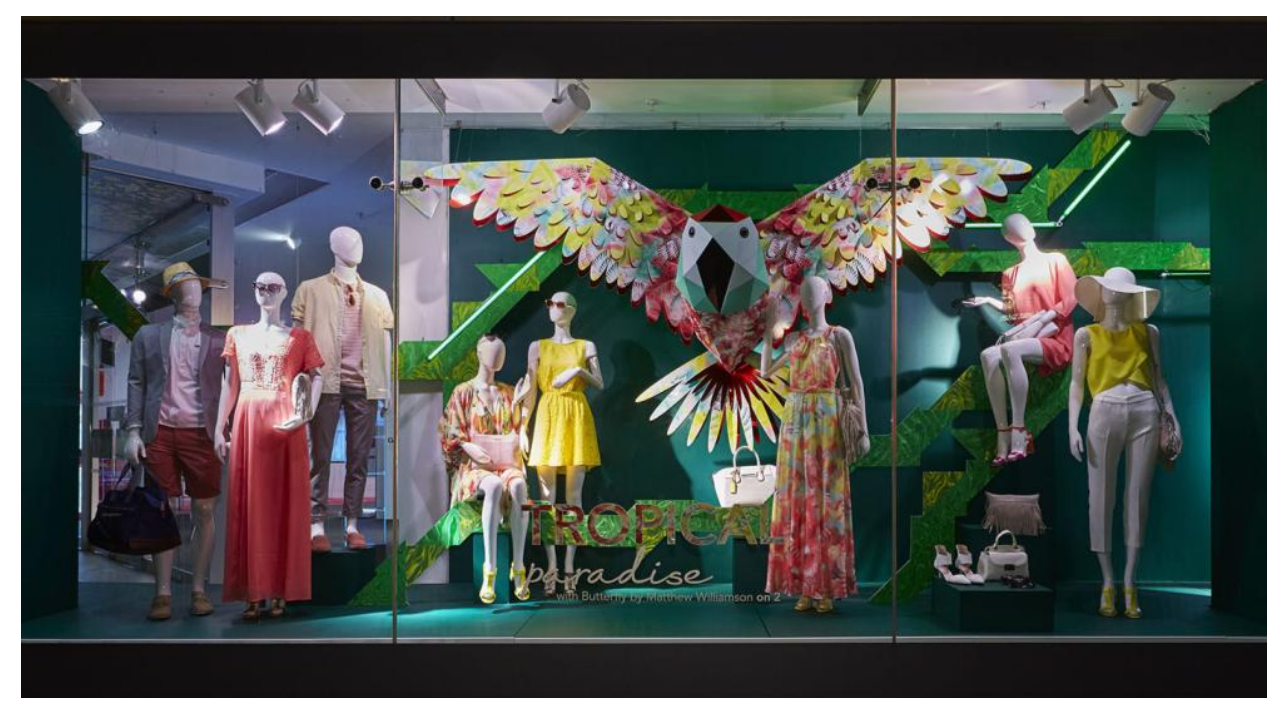

\subsection{IDENTIDADE VISUAL NA FACHADA}

Não basta ter uma arquitetura adequada à função comercial, sem cuidar da gestão da marca em todas as suas possibilidades. Neste sentido um planejamento da identidade visual da marca é fundamental, afinal é a personalidade desta traduzida em imagem, através do próprio logo, por 
exemplo, que poderá comunicar a empresa visualmente. Segundo Minami (2011):

\begin{abstract}
A linguagem visual necessita possuir algumas características para o seu rápido entendimento, fácil compreensão, independente da língua, da cultura ou do grau de instrução de quem examina a mensagem nela contida, identificando-a através da imagem (símbolo). Então, quando um nome ou idéia é representada visualmente sob uma determinada forma (letra ou desenho), dizemos que ela tem identidade visual. A identidade visual é um conjunto de elementos gráficos que compõem a personalidade visual de um nome, idéia, produto ou serviço. Portanto, o símbolo, na sociedade contemporânea, passa a ser um sinal gráfico que com o uso, identifica um nome, uma idéia, um produto ou um serviço. (MINAMI, 2001).
\end{abstract}

A identidade é a manifestação da personalidade marca, a qual deve estar presente em todos os canais de relacionamento da empresa, ou seja, em seus produtos, lojas, vitrines, materiais de comunicação e etc. Nesse sentido, todos os aspectos da expressão visual da marca, bem como o seu comportamento, podem ser utilizados para exprimir os seus valores e para definir suas relações com seu público (LENCASTRE, 2005).

A marca exige que se faça um sistema pedagógico e normativo rígido para administrar o uso da sua identidade visual, com o intuito de promover uma padronização. A preservação de forma quase religiosa da linguagem visual da marca, ultrapassa a preocupação supérflua, podendo ser considerado tão importante quanto os demais parâmetros do design visual. Isto porque, a identidade visual de uma organização é "uma ferramenta estratégica dentro do contexto mercadológico altamente competitivo, objetivando promover mudanças de comportamento na formação da imagem dessa marca, o que ajudará na sua memorização" (VIEBIG,2005).

Deve-se buscar a padronização da identidade visual da marca, ou seja, em todos os meios de exposição (Figura 166) - fachada, placas, sacolas, uniformes, artigos de papelaria, ela deve estar presente e aplicada da maneira planejada pelo designer. 
Figura 166.

Exemplo de aplicação da marca Chuvisco em diversas possibilidades Fonte: Acervo pessoal da
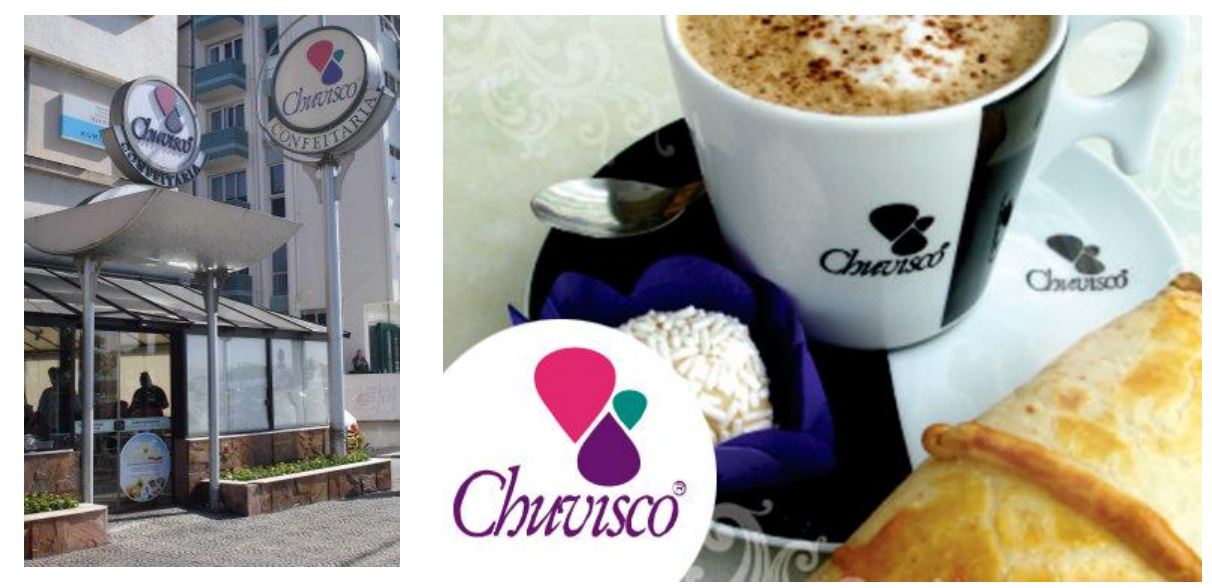
autora.

Uma placa de identificação na fachada, que esteja de acordo com o público alvo da loja e seja visualmente adequada, isto é, com cores, tamanho, iluminação, tipografia aplicados de maneira correta ao que a marca pretende transmitir, funcionará como uma comunicação direta com o consumidor.

Uma placa de sinalização efetiva numa fachada consegue marcar a memória do consumidor e atraí-lo visualmente. Para tanto, é preciso entender qual o melhor tipo de placa e material a ser utilizado em cada situação.

Existem quatro principais tipos de sinalização da marca: com letras caixas, recortes eletrônicos, impressão digital e painel.

As letras caixas é um dos métodos mais antigos de sinalização, bastante eficaz em sua utilização e apresentação, consiste no uso apenas das letras que compõe o nome ou no uso do logotipo da loja, deixando sua fachada com um a imagem mais limpa. É possível alcançar bons resultados na fachada da loja, transmitindo conceitos de sofisticação e requinte.

Pode ser produzido em diversos cores e materiais (Quadro 7), como MDF, acrílico - colorido, transparente e fosco, aço galvanizado, aço inox - com acabamento de aço escovado ou polido, latão e em neon. Todos estes tipos de letreiros podem ser iluminados, o que geralmente ocorre com lâmpadas de LED. 


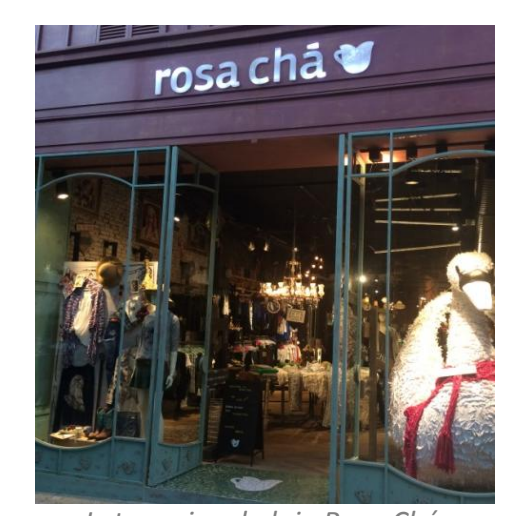

Letra caixa da loja Rosa Chá Fonte: Acervo pessoal da autora

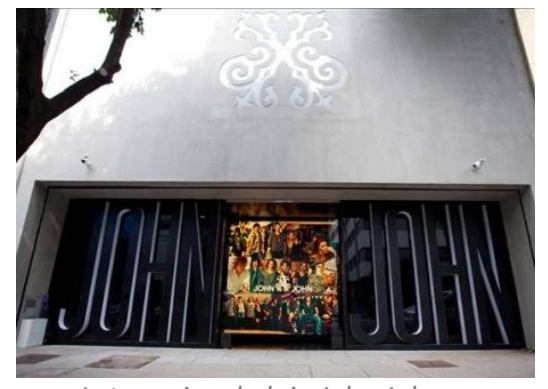

Letra caixa da loja John John

Fonte: Acervo pessoal da autora.

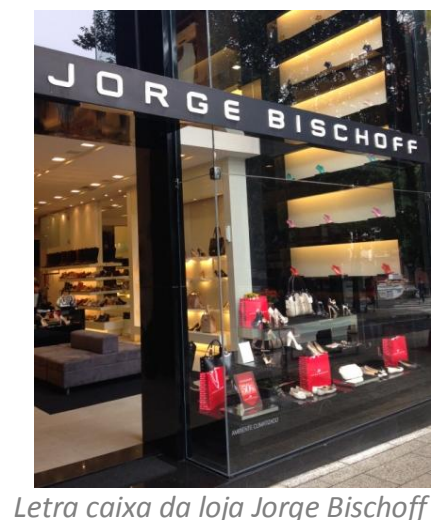

Fonte: Acervo pessoal da autora.

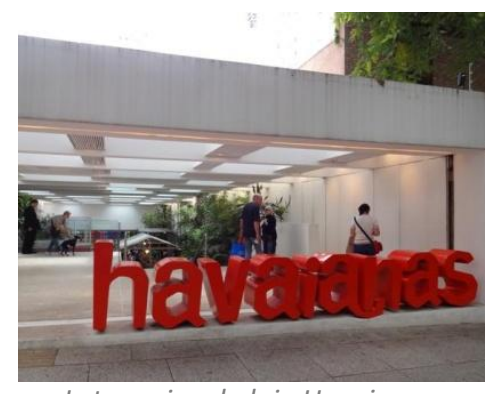

Letra caixa da loja Havaianas Fonte: Acervo pessoal da autora.
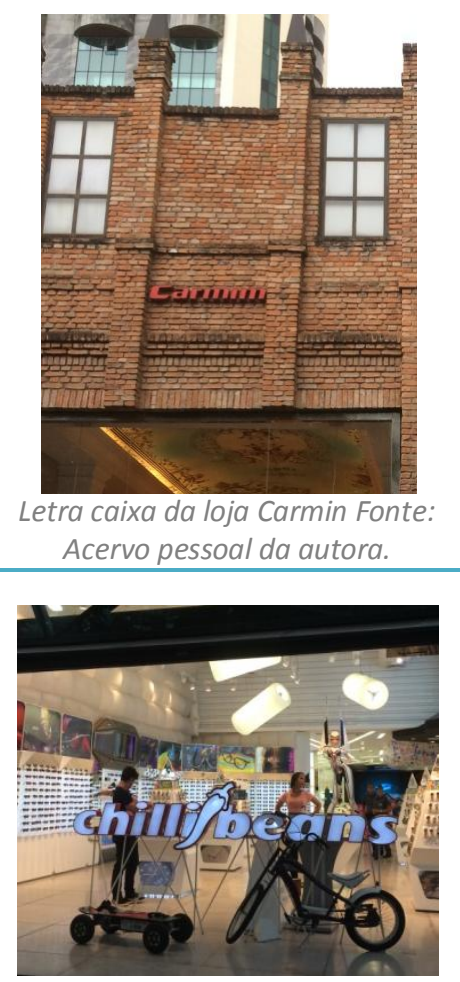

Letra caixa da loja Chilli Beans Fonte: Acervo pessoal da autora.

Um fator importante ao se utilizar a letra caixa é o local onde ela será fixada. Nas situações em que as letras são colocadas diretamente sobre o vidro da vitrine, a leitura se torna muitas vezes ilegível, pois a sinalização acaba por se confundir com o fundo da loja (Quadro 8).
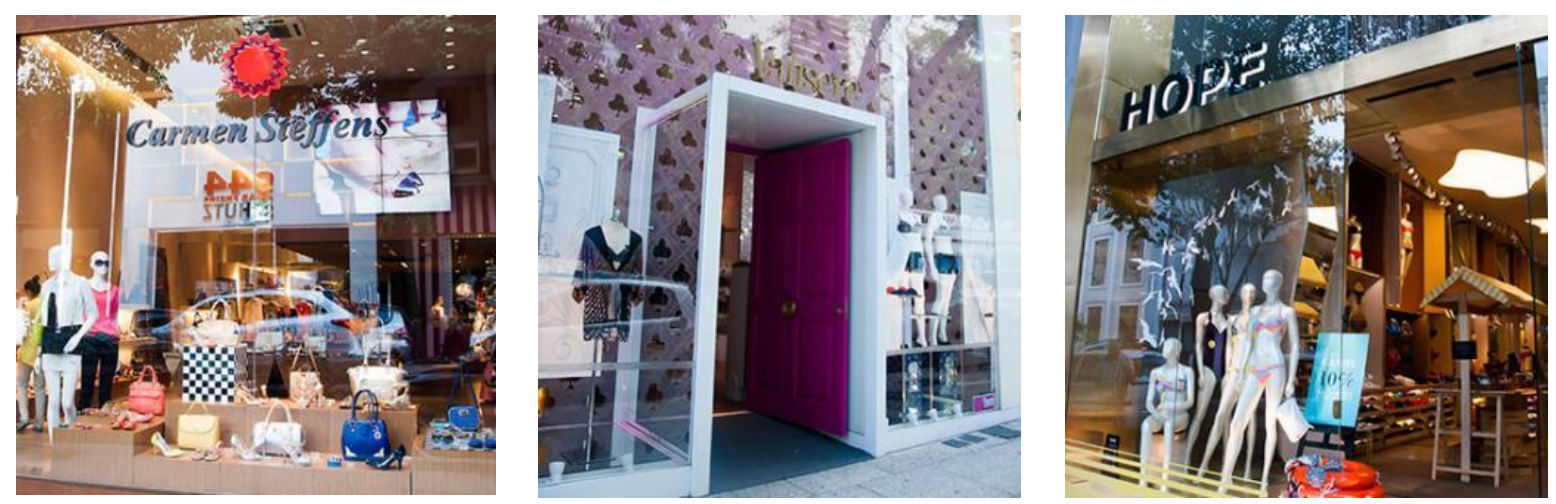

O segundo tipo de placa de grande ocorrência são as que utilizam recorte eletrônico (Quadro 9). É um dos meios mais baratos e consiste na colagem 
de adesivos sobre superfícies. O adesivo é impresso e recortado eletronicamente e então aplicado em diversos suportes, tais como lonas, vidros, painéis de metal, paredes, entre outros.

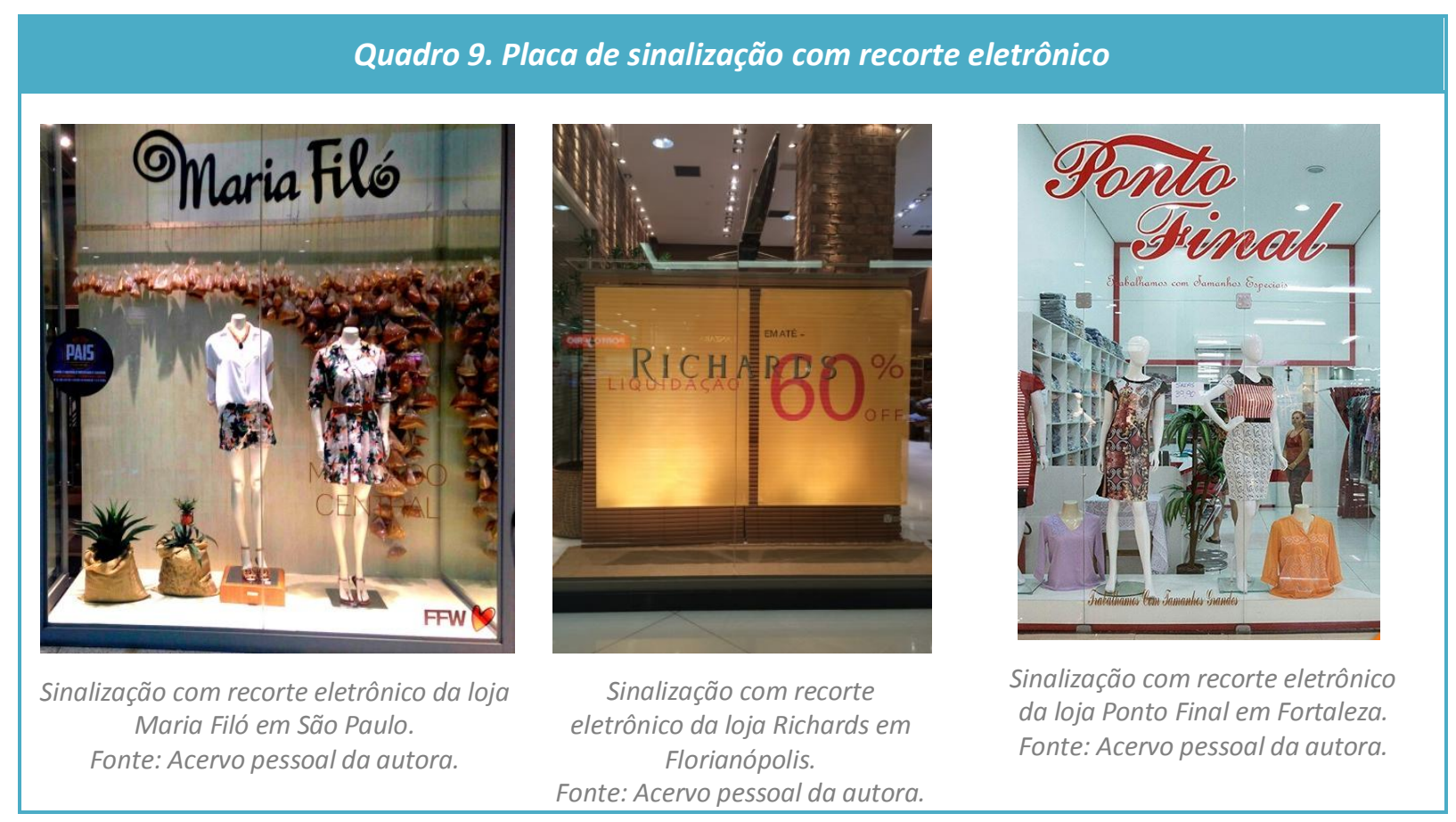

Há ainda as placas de sinalização feitas através do processo de impressão digital. Estas são confeccionadas através de uma lona (vinil) pregada ou grampeada na parte frontal de uma estrutura de ferro. Pode-se ainda fiá-las a estrutura, amarrando-a placa através de ilhoses, que são pequenos orifícios metálicos, por onde são transpassadas as fitas de amarração.

Este tipo de placa pode ser iluminada através de duas maneiras. A Front Light (Figura 167), onde a iluminação é feita através de lâmpadas e holofotes externos e a Back Light (Figura 168), onde a iluminação provém de lâmpadas, normalmente fluorescentes, que estão posicionadas na parte interna da placa. 
Figura 167. Sinalização com impressão digital e iluminação Front

Light
Fonte:

https://br.pinterest.com/pin/ 391039180125295155/

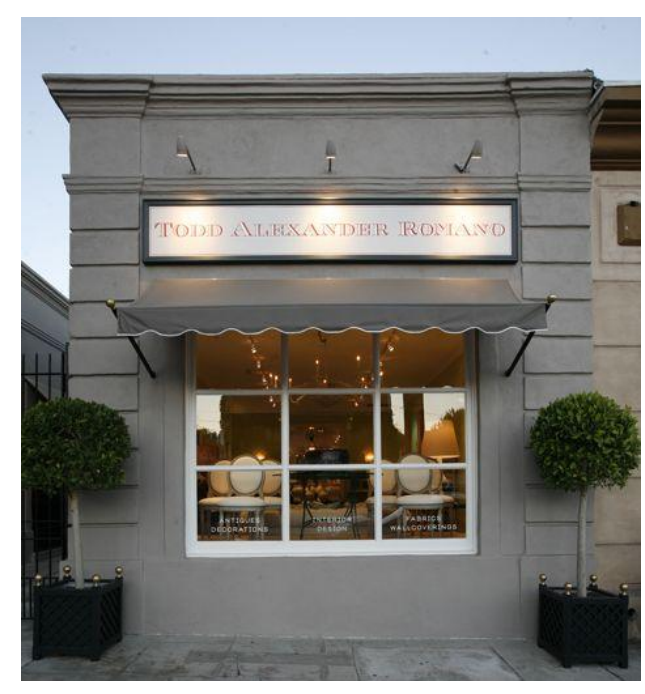

Figura 168.

Sinalização com impressão digital da loja LoveToys da Oscar Freire - São Paulo

Fonte: Acervo pessoal da autora.

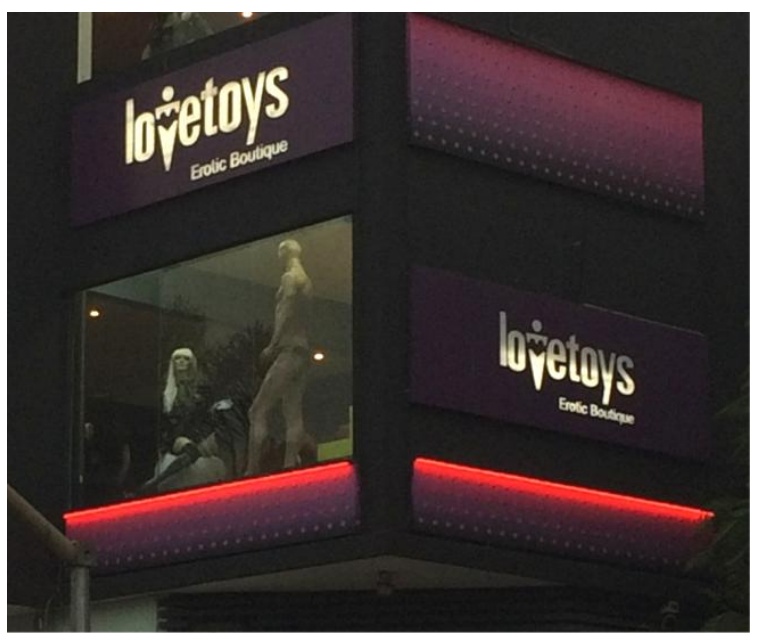

Por fim, existem as sinalizações feitas com painéis onde as marcas são gravadas ou recortadas nestes. Normalmente este processo ocorre através de um corte com router, que é um processo de execução feito a partir de um desenho gerado por computador, que repassado ao software da máquina permite que esta execute gravações, entalhamentos e rebaixamentos em diversos tipos de materiais.

Estes painéis podem ser compostos de alumínio, acrílico e até madeira (Quadro 10) e podem ter, ou não, iluminação Front Light ou Back Light. 


\section{Quadro 10. Placas de identificação de painéis de}

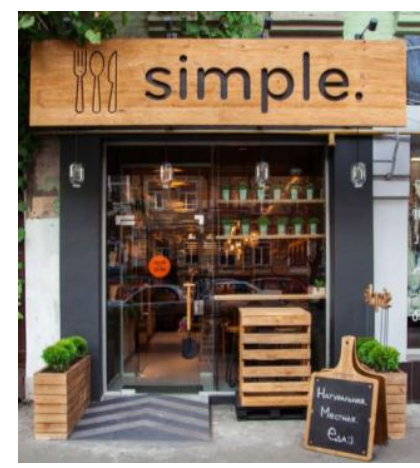

Placa de identificação tipo painel de madeira com gravação da marca em baixo relevo. Fonte: $h$ ttp://designmilk.com/designing-modern-fastfood-restaurant/

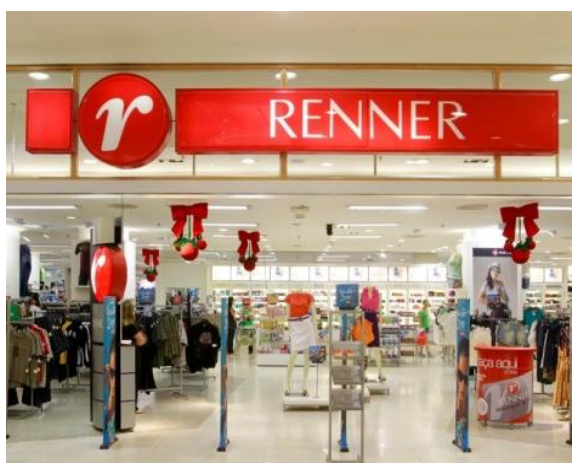

Placa de identificação tipo painel de acrílico Fonte: Acervo pessoal da autora.

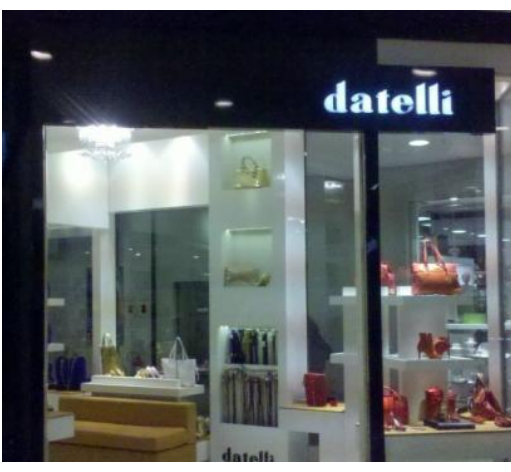

Placa de identificação tipo painel de alumínio (ACM) com iluminação back light.

Fonte: Acervo pessoal da autora.

O mais importante das formas de comunicação visual, é que para cada segmento e público, terá uma placa que transmitirá melhor os preceitos da loja. Em uma loja infantil, por exemplo, usar na fachada uma placa de sinalização preta com letras brancas, como a utilizada pela loja Baby GAP (Figura 169) não parece ser a melhor alternativa, pois não transmite nenhuma característica infantil e traz um formalismo exacerbado. Uma sinalização com uma tipografia menos sóbria e cores mais alegres parece se comunicar melhor com o público infantil (Figura 170).

Figura 169.

Placa de sinalização da loja Baby GAP

Fonte:

http://www.horwitzaandd.co $\mathrm{m} /$ project-gap.html

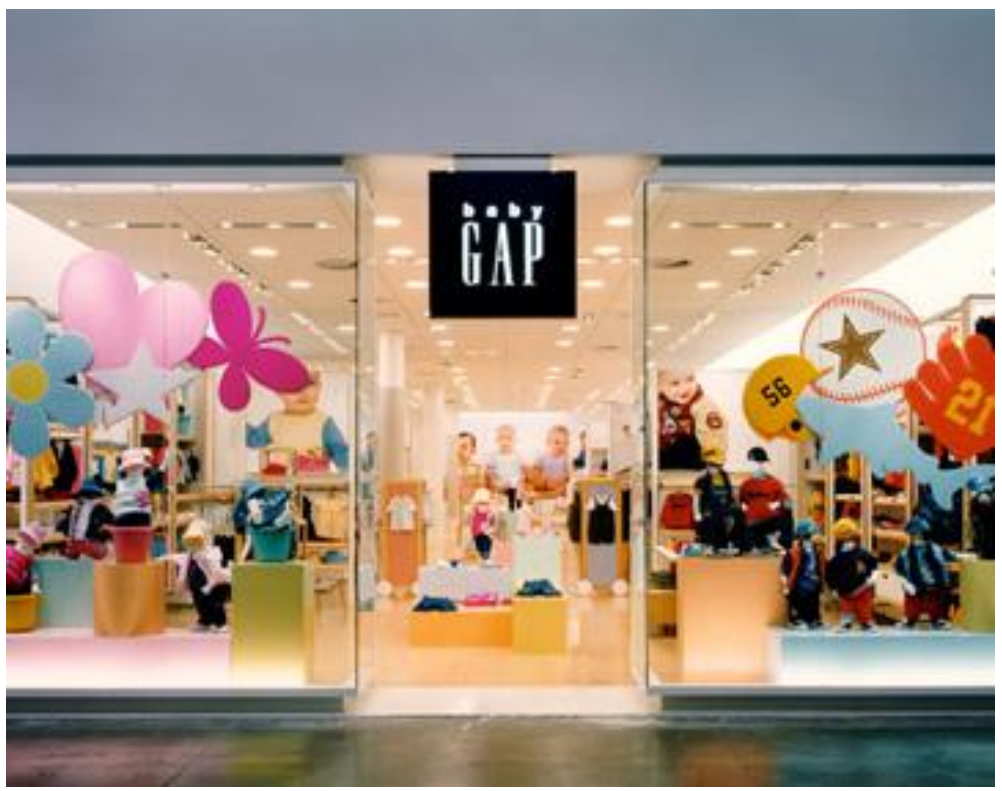


Figura 170. Placa de sinalização da loja Ri Happy de Florianópolis Fonte: Acervo pessoal da

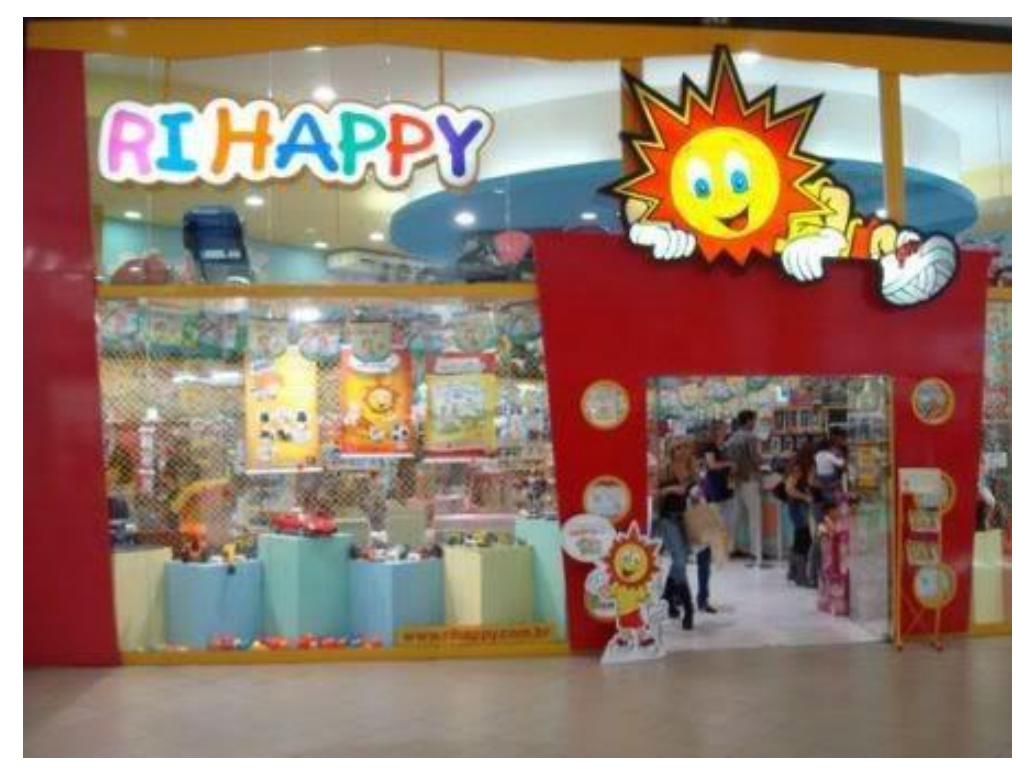
autora. 


\section{Capítulo 5}

\section{Considerações Finais}

As relações entre o comércio e a cidade fazem parte da essência humana. 0 comércio faz parte da razão de existência da cidade, não havendo uma só civilização que tenha desenvolvido a vida urbana sem a presença das trocas comerciais. É o comércio que desempenha papel articulador do espaço urbano, justificando muita da animação ocorrida na cidade. Através dos ambientes comerciais, veicula-se informação, difundem-se inovações, criam-se laços de sociabilidade, despertam-se desejos e as pessoas satisfazem necessidades - reais ou criadas (Barata Salgueiro, 1996).

No entanto, as relações que o comércio estabelece hoje com a cidade são bem diferentes das vividas noutros tempos. Isso se deve sobretudo, a forma como os ambientes comerciais tem respondido as necessidades da sociedade do consumo.

Cada vez mais torna-se evidente a importância de se entender os motivos que levam o consumidor a comprar. Nesta pesquisa, vimos que o comportamento de compra do consumidor é influenciado por diferentes fatores: culturais, sociais, pessoais e psicológicos, e que a maioria dos consumidores entra no ponto de venda sem ao menos planejar a compra, ou seja, são os estímulos criados no ambiente que geram uma necessidade 
momentânea para que seja adquirido algo, o que foi chamado de compra por impulso.

Como a maioria das vendas acontece por impulso, a vitrine tem papel fundamental no visual da loja, pois é a partir dela e dos estímulos que ela oferece que o cliente entrará em contato com os produtos e poderá ser atraído para o interior da loja, e consequentemente, para compra.

Como explanado no capítulo 2, cada consumidor perceberá a realidade de forma diferente, tendo percepções distintas sob um mesmo objeto ou produto, pois cada consumidor sofrerá processos psicológicos centrais individuais que moldarão os seus aspectos de motivação e de comportamento.

Independente destes processos serem individuais e influenciados por processos de aprendizagem, processamento de informação e mudança de atitude e comportamento, é possível através de parâmetros de design visual aumentar as chances de sucesso de uma vitrine.

Um dos fatores primordiais para o sucesso da vitrine é a sua composição. Como apontado no capítulo 4, são três os parâmetros de design visual ligados à composição: equilíbrio, ritmo e unidade. $O$ equilíbrio na vitrina pode ser obtido tanto por uma composição simétrica ou assimétrica. 0 ritmo, segundo princípio que rege uma boa composição, se dará tanto pela relação entre forma, linha e cor, quanto através de técnicas de repetição destes elementos. Por isso, a importância da unidade, uma vez que fazem parte deste parâmetro as linhas e formas, que auxiliam a exposição dos produtos, criando uma unidade visual mais organizada e eficiente. 0 conhecimento das sensações transmitidas pelas formas e linhas torna-se fundamental, pois além de utilizá-las com consciência, podendo-se prever a leitura do consumidor, é possível criar percursos visuais, que valorizem objetos ou a própria composição.

O segundo fator apontado nesta pesquisa, foi a exposição dos produtos, pois não basta ter conhecimento de uma boa composição, sem compreender os critérios para expor um produto. Assim, foi apontado as 
diretrizes básicas para a exposição numa vitrine, sendo as principais: a relação do campo visual do observador, o ponto focal e o caminho visual.

O terceiro fator apontado foi a iluminação, que além de ter um papel técnico que permite a visualização dos produtos e da vitrine como um todo, é uma das responsáveis principais por criar uma atmosfera psicológica. Esta atmosfera é definida pela quantidade de luz utilizada, pela forma como é instalada e por parâmetros físicos da luz, como temperatura e índice de reprodução de cor.

O quarto fator foi o uso da cor. Visto por muitos como elemento de decoração, a cor é na sua essência um elemento de comunicação, que tem o poder de estimular visualmente o observador. Assim, ao escolher a cor a ser utilizada num ambiente comercial, se deve realizar de forma consciente, baseando-se nos princípios estabelecidos pela marca, conceito da loja e, claro, nas associações psicológicas pertinentes a cada pigmento.

Os elementos decorativos e de apoio foram o quinto fator discutido nesta pesquisa. Estes elementos são todos aqueles presentes na vitrine, mas que não se encontram à venda. Podem ser utilizados tanto para alcançar uma composição e exposição dos produtos adequada, quanto para tornar os objetos mais visíveis e atraentes.

Por fim, o último fator apontado foi a identidade visual na fachada, como forma de manifestação da marca através de placas de identificação. Foram agrupadas em quatro categorias principais de sinalização de forma a facilitar a leitura e compreensão visual de tais categorias.

Assim, uma vitrine que leve em consideração os parâmetros de design visual apontados nesta dissertação, possivelmente será capaz de encantar o cliente e criar o desejo pela mercadoria, instigando a decisão da compra, além de auxiliar na criação de identidade e na transmissão do conceito da marca.

Outra contribuição importante deste trabalho, foram as categorias criadas para agrupar as lojas que tem buscado se reinventar e trazer uma resposta espacial as demandas desse consumidor hedonista, que busca vivenciar o 
consumo através do prazer. Ainda mais, tendo em vista a crescente dificuldade de se criar uma diferenciação a partir apenas da localização, mercadorias, preços ou promoções. Portanto, o ponto de venda tem se destacado como oportunidade para criar esta diferenciação através de práticas do design visual.

As categorias de loja multifunção, com espaço semi-público, experiência, conceito e escultural, buscaram abranger as diferentes configurações adotadas pelos atuais ambientes comerciais, trazendo referências da cidade de São Paulo, de modo a ilustrar tais categorias.

Apontou-se a importância em se estabelecer uma comunicação com o consumidor em todas as possibilidades de tempo e espaço. Independente da loja estar fechada, seja devido ao horário comercial ou a questões ligadas a reforma, por exemplo, a fachada do ambiente comercial pode ser transformada num espaço bastante diversificado, onde sejam criadas narrativas, constituindo espaços para descobertas informativas, culturais e estéticas, estabelecendo diálogos entre a marca e o público de maneira criativa.

A partir deste trabalho acreditamos poder contribuir com a melhoria no desempenho dos ambientes comerciais, no que diz respeito aos parâmetros de projeto e relação do ambiente comercial com a marca nele comercializada, propiciando projetos comercias de maior qualidade, inseridos no contexto da cidade e que atendam às necessidades e desejos de experiência do consumidor atual.

No que diz respeito aos possíveis desdobramentos, foram abertas novas possibilidades de pesquisas e caminhos no sentido de orientar futuros trabalhos que alinhem as práticas de design visual a ambientes comerciais. Há muitas oportunidades para outras pesquisas a partir das questões levantadas por este trabalho, uma vez que se trata de um tema multidisciplinar e muito abrangente.

Uma destas oportunidades são os estudos referentes as macrotendências e a forma como estas tem gerado respostas nos ambientes comerciais. Outra 
oportunidade é o aprofundamento desta pesquisa através do ramo da economia, fazendo um levantamento de dados que indiquem o impacto dos parâmetros pertinentes ao design visual no aumento do consumo de um estabelecimento.

Sendo o ambiente comercial uma consequência direta da relação da arquitetura com o consumo, tão logo tornar-se-á necessário avaliar as modificações no perfil dos novos consumidores e a forma como isso pode ser utilizado para projetar os novos ambientes. 


\section{REFERÊNCIAS}

ABERCROMBIE, Nicholas. The authority of the consumer. New York: Routledge, 1994.

AHUVIA, Aaron C. Beyond the Extended Self: Loved Objects and Consumers Identity Narratives. Journal of Consumer Research, Gainesville, v. 32, p. 171 a 184, jun., 2005

AMARAL, Aracy. A Emergência do Design Visual. São Paulo: Melhoramentos e DBA Artes Gráficas, 1998.

ARNHEIM, Rudolf. Arte e Percepção Visual. São Paulo: Pioneira/EDUSP, 1997.

BARRETTO, Margarita. Processos de revitalização urbana e a percepção dos usuários. Arxiu d'Etnografia de Catalunya, n. 13, 2013.

BASSO, Cristiani Tercia Rosseto. Gestão do Visual de Loja: sua loja planejada para vender melhor. Manual do participante. Brasília: SEBRAE, 2008.

BAUMAN, Zygmunt. Modernidade e ambivalência. Rio de Janeiro: Jorge Zahar, 1999.

Vida para consumo: A transformação das pessoas em mercadoria. Rio de Janeiro: Jorge Zahar, 2008. 
BENSON, A. Conclusion: what are we shopping for? In: BENSON, A. I shop, therefore I am: compulsive buying and the search for the self. Northvale: Jason Aronson, 2000

BLESSA, Regina. Merchandising no ponto-de-venda. 4. ed. São Paulo: Atlas, 2010.

BLESSA, Regina. Merchandising no ponto-de-venda. São Paulo: Atlas, 2001.

BÓGEA, Marta. Cidade errante: arquitetura em movimento. São Paulo: Editora Senac São Paulo, 2009.

BUENO, Maria Lucia; CAMARGO, Luiz Octavio de Lima (org.). Cultura e consumo: estilos de vida na contemporaneidade. São Paulo: Editora Senac, 2008.

CACHINHO, Herculano; SALGUEIRO, Teresa Barata. O Comércio Urbano em Tempos de Turbulência: elementos para avaliar as vulnerabilidades e níveis de resiliência. Actas do XII Colóquio Ibérico de Geografia. Porto: Faculdade de Letras (Universidade do Porto) 2010.

CALVINO,Italo. Cidades invisíveis. Trad. Diogo Mainardi. Companhia das Letras, 1997.

CAMPBELL, Colin. A ética romântica e o espírito do consumismo moderno. Rio de Janeiro: Rocco, 2001.

CANEVACCI, Massimo. Comunicação visual. São Paulo: Brasiliense, 2009.

CARLOS, Ana Fani Alessandri. A cidade. São Paulo: Contexto, 1992.

CASARIN, Vanessa; SANTIAGO, Alina Gonçalves. Uma reflexão acerca do papel do arquiteto na construção da paisagem informacional. Paisagem e Ambiente: ensaios, n. 31, São Paulo, 2013. p. 147- 160.

CHIACHIRI, Roberto. O poder sugestivo da publicidade: uma análise semiótica. São Paulo: Cengage Learning, 2010.

CHOAY, Françoise. O Urbanismo. São Paulo, Editora Perspectiva, 2000. 
CHURCHILL, Gilbert A.; PETER, J. Paul. Marketing: criando valor para os clientes. São Paulo: Saraiva, 2003.

COSTA, F. C. X; LARÁN, J. A compra por impulso em ambientes on-line. RAE, São Paulo, v.43, n.4, out./dez. 2003

CREPALDI, Lideli. A influência das cores na decisão de compras: um estudo do comportamento do consumidor no $A B C$ paulista. XXIX Congresso Brasileiro de Ciências da Comunicação. Intercom - Sociedade Brasileira de Estudos Interdisciplinares da Comunicação. Brasília: UNB, 2006.

CSIKSZENTMIHALYI, Mihaly. Flow: the psychology of optimal experience. New York: Harper \& Row, 1990.

CULLEN, G. Paisagem urbana. São Paulo: Edições 70, 1984.

CURY, Luis Fernando. As paisagens da comunicação ao ar livre. In: Congresso Brasileiro de Ciências da Comunicação - INTERCOM, 27, 2004, Porto Alegre. CD-ROM.

CZINKOTA, Michael R.; DICKSON, Peter R.; DUNNE, Patrick; GRIFFIN, Abbie. Marketing: as melhores práticas. Porto Alegre: Bookman, 2001.

D’ANGELO, C. André. Valores e significado do consumo de produtos de luxo. Dissertação (Mestrado em Administração), Programa de pós-graduação em Administração, Universidade Federal do Rio Grande do Sul, Porto Alegre, 2004.

DEBORD, Guy. A Sociedade do Espetáculo. E-book digitalizado por Coletivo Periferia e eBooks Brasil, 2003.

DELEUZE, Gilles; GUATTARI, Fattari. O que é Filosofia? São Paulo: Editora 34, 2010.

DEMETRESCO, Sylvia. Vitrina: construção de encenações. São Paulo: Editora Senac, 2001.

DEMETRESCO, Sylvia; MAIER, Huguette. Vitrinas entre_vistas: merchandising visual. São Paulo: SENAC, 2004. 
DEMETRESCO, Sylvia; REGAMEY. Rita. Tipologia e estética do visual merchandising. São Paulo: Estação das Letras e Cores, 2012.

DONDIS, Donis A. A sintaxe da linguagem visual. São Paulo: Martins Fontes, 1991.

ENGEL, James F.; BLACKWELL, Roger D.; MINIARD, Paul W. Comportamento do consumidor. 9a. ed. Rio de Janeiro: THOMSON PIONEIRA, 2004.

FABER. R.; O'GUINN, T. Compulsive consumption and credit abuse. Journal of Consumer Policy, v. 11, n. 1, p. 97-109, Mar. 1988.

FARINA, Modesto; PEREZ, Clotilde; ASTOS, Dorinho. Psicodinâmica das cores em comunicação. São Paulo: Blucher, 2011.

FERRARA, Lucrécia D' Alessio. Design em espaços. São Paulo: Edições Rosari, 2002

FERRARA, Lucrécia D' Alessio. Ver a cidade: cidade, imagem, leitura. São Paulo: Nobel, 1988.

FIGUEIRA NETO, Arlindo Ornelas. A mídia: o conceito e as atividades. In: PEREZ, Clotilde e BARBOSA, Ivan Santo. Hiperpublicidade - atividades e tendências. São Paulo: Thomson, 2008, vol. 2.

FIGUEIREDO, Robertha. A dissonância cognitiva no marketing. 2012. Disponível em: http://www.administradores.com.br/artigos/marketing/adissonancia-cognitiva-no-marketing/63178/ Acesso em: 17/out/2015.

FILHO, Alvaro de Melo. Fragmentos de Cultura. Goiânia, v.19, n.2, p. 307324, mar/abr 2009.

GADE, C. Psicologia do consumidor e da propaganda. São Paulo: EPU, 1998.

GALINDO, Daniel dos Santos. Comunicação mercadológica: Uma visão multidisciplinar. São Bernardo do Campo: Universidade Metodista de São Paulo, 2008.

GARRET, Lillian. Visual design: a problem-solving approach. Michigan: R. E. Krieger Pub. Co., 1975. 
GIDDENS, Anthony. A identidade cultural na pós-modernidade. Rio de Janeiro: DP\&A, 2000.

Modernidade e identidade. Rio de Janeiro: Jorge Zahar, 2002.

GIMPEL, José Luiz. Administração de Empresas Varejistas no Brasil. São Paulo: Editora Atlas, 1980.

GUIDÉ, Gwenola; HERVÉ, Dominique; SACKRIDER, Françoise. Entre Vitrinas: Distribuição e Visual Merchandising na Moda. São Paulo: Senac, 2009.

HALL, Stuart. A Identidade Cultural na Pós-Modernidade. Rio de Janeiro: DP\&A, 2001.

HARDT, L. P. A. Subsídios à gestão da qualidade da paisagem urbana. 2000. $323 \mathrm{f}$. Tese (Doutorado em Engenharia Florestal) - Universidade Federal do Paraná, Curitiba, 2000.

HARVEY, David. A arte de lucrar: globalização, monopólio e exploração da cultura. In: MORAES, Denis de (org). Pó uma outra comunicação. Mídia mundialização cultural e poder.São Paulo: Record. 2004.

HIRSCHMAN, Elizabeth C.; HOLBROOK, Morris B. Postmodern consumer research: The study of consumption as text. Newbury Park: Sage Publications, 1992.

HIRSCHMAN, Elizabeth C; STERN, Barbara B. The Roles of Emotion in Consumer Research. in: NA - Advances in Consumer Research Volume 26, eds. Eric J. Arnould and Linda M. Scott, Provo, UT : Association for Consumer Research, 1999.

HOMEM DE MELO, Francisco Inácio. Caos e Ordem no Ambiente Urbano. Exploração visual do signo arquitetônico e do signo informacional. Dissertação de Mestrado. São Paulo, USP, 1985.

JAMESON, Fredric. Pós-modernismo: a lógica cultural do capitalismo tardio. São Paulo: Ática, 1997, 2ạ edição. 
KERIN, Roger A.; HARTLEY, Steven W.; BERKOWITZ, Eric N.; RUDELIUS, William. Marketing. Porto Alegre: AMGH, 2007.

KOTLER, Philip; KELLER, Kevin Lane. Administração de Marketing. 12a Edição, São Paulo: Editora Pearson Prentice Hall, 2006.

LENCASTRE, Paulo de (org). O livro da marca. Lisboa: Dom Quixote, 2005.

LINDSTROM, Martin. A lógica do consumo. Rio de Janeiro: Nova fronteira, 2009.

LINDSTROM, Martin. Brandsense: a marca multissensorial. Porto Alegre: Bookman, 2007.

LIPOVETSKY, Gilles e ROUX, Elyette. O Luxo Eterno: da idade do sagrado ao tempo das marcas. São Paulo: Companhia das Letras, 2005.

LIPOVETSKY, Gilles. O Império do efêmero: a moda e seu destino nas sociedades modernas. São Paulo: Companhia das Letras, 1989.

. A felicidade paradoxal: Ensaio sobre a sociedade do hiperconsumo. São Paulo: Companhia das Letras, 2007.

LOURENÇO, Fátima; SAM, José Oliveira. Vitrina: Veículo de Comunicação e Venda. São Paulo: Editora Senac São Paulo, 2011.

LYNCH, Kevin. A imagem da cidade. Ed. Martins Fontes. São Paulo, 1999.

MALHOTRA, Naresh. Design de loja e merchandising visual: criando um ambiente que convida a comprar. São Paulo: Editora Saraiva, 2013.

MARÍN, Dioni. Design de vitrinas. Barcelona: Instituto Monsa de Ediciones, 2005.

MENDES, Camila Faccioni. Paisagem urbana: uma mídia redescoberta. São Paulo: Senac, 2006.

MESTRINER, Fábio. Design de embalagem: Curso Avançado. 1‥ ed. São Paulo: Prentice Hall, 2002. 
MINAMI, Issao. Paisagem urbana de São Paulo: Publicidade externa e poluição visual. Junho, 2001. Disponível em: http://www.vitruvius.com.br/arquitextos/arq000/esp074.asp. Acesso em: $26 / 10 / 2015$.

MINAMI, Issao; GUIMARÃES JÚNIOR, João Lopes. A questão da ética e da estética no meio ambiente urbano ou porque todos devemos ser belezuras. Agosto, 2001. Disponível em: http://www.vitruvius.com.br/arquitextos/arq000/esp094.asp. Acesso em: $26 / 10 / 2015$

MINISTÉRIO DO MEIO AMBIENTE (MMA); IDEC; MEC; CONSUMIERS INTERNATIONAL. Consumo sustentável: manual de educação. Brasília: 2005. Disponível em: <hhtp://www.mma.gov.br/port/sds/guia.htm> Acesso em: $15 / 08 / 2015$.

MONTEIRO, Marcelo. O design, a interação com o marketing e a conjuntura socieconômica, cultural e ambiental. Dissertação de mestrado FAU/USP. SP, 2014.

MOREIRA, R. Repensando a Geografia. In: SANTOS, M. (org.). Novos rumos da Geografia Brasileira. São Paulo: Hucitec, 1988.

MORGAN, Tony. Visual Merchandising: Vitrines e Interiores Comerciais. São Paulo: Gustavo Gili, 2011.

MOWEN, J. C.; MINOR, M. S. Comportamento do consumidor. São Paulo: Pearson Education do Brasil, 2004.

MÜLLER-BROCKMANN, Josef. Historia de la comunicación visual. Barcelona: G.Gilli, 1988.

MUNARI, Bruno. Design e Comunicação Visual. São Paulo: Martins Fontes, 1997.

NORMAN, Donald. Design Emocional: Por que adoramos (ou detestamos) os objetos do dia-a-dia. 1aed. Rio de Janeiro: Rocco, 2008. 
OHTAKE, Ricardo (coord.) A Gráfica Urbana. Cadernos 7. São Paulo: Secretaria Municipal de Cultura. Departamento de Informação e Documentação Artísticas. Centro de Documentação e Informação sobre Arte Brasileira Contemporânea, 1982.

PANIZZA, Janaina F. Metodologia e processo criativo em projetos de comunicação visual. Dissertação (Mestrado em Ciências da Comunicação). Escola de Comunicação e Artes da Universidade de São Paulo, São Paulo, 2004.

PARENTE, Juracy. Varejo no Brasil: Gestão e Estratégias. São Paulo: Atlas, 2000.

PASSINI, Romedi. Wayfinding in architecture. New York, USA, Van Nostrand Reinhold Company Inc. 1984.

PEREZ, Clotilde. Signos da marca: expressividade e sensorialidade. São Paulo: Thomson Learning, 2004.

PEREZ, Clotilde. Universo Sígnico do Consumo: o sentido das marcas. Tese de Livre-docência; Escola de Comunicações e Artes. Universidade de São Paulo, 2007.

PINTO, Syomara dos Santos Duarte. Vitrinas : expondo e revendo conceitos. Um breve olhar sobre Fortaleza. Dissertação (Mestrado). Faculdade de Arquitetura e Urbanismo da Universidade de São Paulo, São Paulo, 2005.

PLASCAK, Nicole. A Experiência sensorial da marca pós-moderna. In: Congresso Brasileiro de Ciências da Comunicação, XXXI, 2008, Natal. Disponível em: <http://www.intercom.org.br/papers/nacionais/2008/resumos/R3-11531.pdf> Acesso em: 10 jul. 2014.

PULLMAN, Madeleine; GROSS, Michael. Welcome to Your Experience: where you can check out anytime you'd like, but you can never leave. Journal of Business and Management, vol. 9, no 3, p. 215-232. 2003. 
QUELUZ, Marilda Lopes Pinheiro. Design \& Identidade. Curitiba: Ed. Peregrina, 2008.

REBELLO, Aiuri. Feira de artigos católicos é retrato de um mercado bilionário. Revista Veja, julho/2011. Disponível em: < http://veja.abril.com.br/noticia/economia/expocatolica-e-retrato-de-ummercado-bilionario> Acesso em: 23/09/2015.

RODRIGUES, Eloisa Ramos Ribeiro. Shopping a céu aberto no Brasil: transformações, estratégias e perspectivas da rua comercial na sociedade de consumo contemporânea. Tese (Doutorado em Arquitetura e Urbanismo). FAUUSP, São Paulo, 2012.

ROQUE, Wagner. O Mercado da acessibilidade está em alta. Revista Pequenas Empresas \& Grandes Negócios, setembro/2007. Disponível em: http://revistapegn.globo.com/Empresasenegocios/0,19125,ERA16237262484,00.html Acesso em: 11/03/2015.

SACKRIDER, Françoise; GUIDÉ, Gwenola; HERVÉ, Dominique. Entre Vitrinas Distribuição e Visual Merchandising na Moda. São Paulo: Editora Senac São Paulo, 2009.

SALGUEIRO, Teresa Barata. Do Comércio à Distribuição: roteiro de uma mudança. Celta: Oeiras, 1996.

SALGUEIRO; Teresa Barata; CACHINHO, Herculano. As relações cidadecomercio.Dinâmicas de evolução e modelos interpretativos. In: CARRERAS, C.; PACHECO, S. M. M. (Org.) Cidade e comércio: a rua comercial na perspectiva internacional. Rio de Janeiro: Armazém das Letras, 2009.

SAMPAIO, Inês Silva Vitorino. Televisão, publicidade e infância. São Paulo: Annablume, 2000

SANTAELLA, Lúcia. Semiótica aplicada. São Paulo: Cengage Learning, 2010.

SANTOS, Milton. Metamorfoses do espaço habitado. São Paulo: Editora Hucitec, 1991. 
SANTOS, Andréia Mendes dos. Sociedade do consumo: criança $e$ propaganda, uma relação que dá peso. Tese (doutorado) - Pontifícia Universidade Católica do Rio Grande do Sul. Faculdade de Serviço Social. Programa de Pós-Graduação em Serviço Social. Porto Alegre, 2007.

SCHIFFMAN, Leon G.; KANUK, Leslie L. Comportamento do consumidor. Ged. Rio de Janeiro: LTC, 2000.

SERRALVO, F. A. O marketing de varejo e o comportamento do consumidor - uma análise das inter-relações de compra e venda. Dissertação (Mestrado). PPGA - Pontifícia Universidade Católica de São Paulo, São Paulo, 1993

SHETH, Jagdish, MITTAL, Banwari; NEWMAN, Bruce. Customer behavior consumer behavior and beyond. Fort Worth: The Dryden Press, 1999.

SILVA, José Afonso da. Direito Urbanístico Brasileiro. São Paulo, Malheiros, 1997.

SLATER, Don. Cultura, consumo e modernidade. São Paulo: Nobel, 2002.

SODRÉ, Muniz. Reinventando a cultura: a comunicação e seus produtos. Petrópolis: Vozes, 1996.

SOLOMON, Michael R. Consumer behavior buying, having and being. 4 th edition. Upper Saddle River, NJ: Prentice Hall, 1999

TAVARES, Fred. O consumo na pós-modernidade: uma perspectiva psicossociológica. Comum, Rio de Janeiro, v.9, no 22, p. 122 a 143, jan./jun., 2004.

THOMPSON Craig J; TROESTER, Maura. Consumer value systems in the age of postmodern fragmentation: The case of the natural health microculture. Journal of Consumer Research, Gainesville, v. 28, p. 550 a 571, mar., 2002.

UNDERHILL, Paco. Vamos às compras: A ciência do consumo nos mercados globais. Ed. Campus, 2009. 
VARGAS, Heliana C. Espaço Terciário: O lugar, a arquitetura e a imagem do comércio. São Paulo: SENAC, 2001.

VARGAS, Heliana Comin. Shopping Centers: Novas Relações Entre a Atividade Comercial e o Espaço Urbano. In: Encontro Nacional da Anpur, 5. 1993, Belo Horizonte. Anais. Belo Horizonte: Anpur, 1995. v.2 p.736-47

VARGAS, Heliana Comin. Espaço Terciário: O lugar, a arquitetura e a imagem do comércio. São Paulo: Senac, 2001

VARGAS, Heliana Comin; CASTILHO, Ana Luisa Howard. Intervenções em centros urbanos: objetivos, estratégias e resultados. 2.ed. rev. Barueri, SP: Manole, 2009.

VARGAS, Heliana Comin; MENDES, Camila Faccioni. O Comércio Não Planejado e Arquitetura Comercial De Transição (The Retailing Design in a Process of Urban Use Substitution). Trabalho apresentado na 6TH INTERNATIONAL CONFERENCE IN RETAILING AND SERVICES SCIENCE. Porto Rico: EIRASS, 1999.

VENTURA, Rodrigo. Mudanças no perfil de consumidor no Brasil: Principais tendências nos próximos 20 anos. Macroplan - Prospectiva, Estratégia e Gestão, 2010.2 Disponível em: $<$ http://macroplan.com.br/documentos/artigomacroplan2010817182941.p df> Acesso em: 20/set/2014.

VENTURI, Robert; BROWN, Denise Scott; IZENOUR, Steven. Aprendendo com Las Vegas. São Paulo: Cosac Naify, 2003.

VIEBIG, Mariléa Carvalho de Oliveira. Comunicação visual nas organizações do terceiro setor: dimensões conceituais e estratégicas. Disponível em: < http://www.bocc.uff.br/pag/viebig-marilea-comunicacao-visualorganizacoes-terceiro-setor.pdf> Acesso em: 06 dez 2010.

VILELA, Carolina; BOABAID, Flavia; DIAS, Patrícia; LUPPI, Raphaella. Casamento: da mitologia aos estilistas. Eclética. Julho/dezembro 2006. Disponível em: http://puc-riodigital.com.puc-rio.br/media/24\%20\%20casamento\%20da\%20mitologia\%20aos\%20estilistas.pdf 
VOLTOLINI, R. Tendências para o consume consciente. In: Revista ideia sustentável. São Paulo, v.19, p. 53-67, mar. 2010. Dossiê 6. Disponível em: <http://ideiasustentavel.com.br/pdf/IS19\%20-\%20Dossie\%20v1.pdf>. Acesso em: 11 ago 2015.

WILKIE, William L. Consumer Behavior. New York: John Wiley \& Sons, Inc., 1994.

ZMYSLOWSKI, Eliana Maria Tancredi. Vitrina: A Vitrina Como Estratégia Sedutora Nos Espaços De Consumo. Dissertação De Mestrado. Universidade Anhembi Morumbi. SP, 2009. 